\author{
Universidade de São Paulo \\ Faculdade de Filosofia, Letras e Ciências Humanas \\ Departamento de Filosofia \\ Programa de Pós-graduação em Filosofia
}

TESE DE DOUTORADO

\title{
O PROJETO DAVIDSONIANO DE UMA SEMÂNTICA COMPOSICIONAL PARA AS LÍNGUAS NATURAIS
}

Michel P. Assis Navarro

Orientador: Prof. Dr. João Vergílio Cuter

São Paulo, 2017

Universidade de São Paulo 
Faculdade de Filosofia, Letras e Ciências Humanas

Departamento de Filosofia

Programa de Pós-graduação em Filosofia

\title{
O PROJETO DAVIDSONIANO DE UMA SEMÂNTICA COMPOSICIONAL PARA AS LÍNGUAS NATURAIS
}

\author{
Michel P. Assis Navarro \\ Versão Corrigida \\ De acordo: \\ Orientador: Prof. Dr. João Vergílio Cuter
}

Tese apresentada ao programa de PósGradução em Filosofia, da Universidade de São Paulo, como requisito para a obtenção do título de Doutor em Filosofia.

São Paulo, 2017 
Ao meu pai, guerreiro e companheiro. 


\section{AGRADECIMENTOS}

Agradeço, em primeiro lugar, ao meu orientador, Prof. Dr. João Vergílio Cuter, pela ética com que trabalha, respeitando a autonomia do orientando e sempre disposto a ajudar em todos os detalhes da pesquisa. Além disso, agradeço ao João pela existência do grupo de estudos entre seus orientandos e conduzido por ele. Neste espaço tive a oportunidade sempre fértil de debater o conteúdo da minha tese, apresentar e reorientar caminhos da minha pesquisa e produção textual em desenvolvimentos ao longo dos quatro anos de doutoramento. Nos mesmos encontros pude também participar dos debates acerca das investigações dos outros orientandos, e pude aprender muito e crescer como pesquisador.

Agradeço aos meus pais, Maria de Lourdes Navarro e Dagoberto Gomes Navarro, pelos seres humanos que são, pelo companheirismo e incentivo amoroso às minhas opções de vida, trabalho e estudo.

Agradeço à minha irmã, Luciana Navarro, pela paciência que teve como minha tradutora na minha tenra infância quando ainda brigava com a linguagem e comunicação para me fazer entender. Talvez venha deste tempo a fonte do meu interesse intelectual pela linguagem e suas funções.

Agradeço à minha irmã Luana Navarro, pelo amor à arte e os seus descaminhos de libertação e conhecimento.

Agradeço aos meus sobrinhos Gian e Nina pela beleza que trazem à vida de todos na família, e por reencantarem a existência dos adultos, não os deixando perderem de todo as reminiscâncias da infância e a presença do olhar lúdico.

Agradeço ao Prof. Dr. Kirk Ludwig, por eu ter tido o privilégio de estar na Universidade de Indiana, nos Estados Unidos, como pesquisador visitante sob sua orientação. Nossos encontros quinzenais no período de um ano foram fundamentais para a maturação da minha pesquisa. Seu profissionalismo e dedicação ficaram como referência para mim do que é ser um pesquisador e professor integral.

Agradeço à Fundação de Amparo à Pesquisa do Estado de São Paulo (FAPESP), processo número 2012/17304-0, por ter assegurado as condições materiais para realização do meu doutorado. Sem o seu apoio esta pesquisa simplesmente seria impossível de se efetivar.

Agradeço, por fim, a todos aqueles que por ventura esqueci de lembrar aqui. Ainda que não registrados nesta folha, de alguma maneira vocês têm parte nesta tese. 


\section{RESUMO}

NAVARRO. M, P, A. O Projeto Davidsoniano de uma Semântica Composicional para as Línguas Naturais. 2017 - Tese (doutorado), p.238 - Faculdade de Filosofia, Letras e Ciências Humanas, Universidade de São Paulo, São Paulo, 2017.

Nesta tese realizo uma exposição e exame sistemáticos do projeto semântico do filósofo estadunidense Donald Davidson de construir uma teoria composicional do significado para as línguas naturais explorando a estrutura recursiva de uma teoria interpretativa da verdade de tipo tarskiana. Nesta estratégia, uma teoria do significado deve ser capaz de capturar a capacidade linguística geral que qualquer falante de uma língua possui de produzir e interpretar novas sentenças. O requerimento de que a teoria seja composicional constitui o critério fundamental que orienta o empreendimento de Davidson e está na base do projeto de elucidar o aspecto composicional do significado via o emprego de uma teoria da verdade do tipo tarskiana. Defendo que o projeto de Davidson intenta lançar as bases de um programa de pesquisa em semântica das línguas naturais que, embora não hegemônico no campo e visto com ceticismo por alguns, é o único exemplo até o momento de uma tentativa de iluminar de forma sistemática o aspecto composicional do significado de amplos fragmentos das línguas naturais sem um apelo direto a entidades abstratas associadas às expressões de uma linguagem, como propriedades, proposições sentidos, intensões etc. Dois tópicos acerca do projeto recebem uma investigação detalhada. Em primeiro lugar, questões filosóficas fundacionais que a proposta suscita. Abordamos as objeções de Davidson a teorias que quantificam sobre significados, discutindo os problemas que ele identifica em análises que reificam a camada intensional dos significados das expressões de uma língua, em especial sistemas neo-fregeanos, tais como os propostos por Rudolf Carnap e Alonzo Church. Baseado em parte nesta crítica de Davidson, pouco examinada na literatura, e sem a qual se corre o risco de uma interpretação equivocada das ambições do projeto, sustento, em consonância com os semanticistas neo-davidsonianos Ernie Lepore \& Kirk Ludwig (2005; 2007), que Davidson não intenta fornecer uma semântica que se caracteriza por substituir ou reduzir uma teoria do significado a uma teoria da verdade. A ideia é que uma teoria composicional do significado pode ser apresentada como um corpo de conhecimento sobre uma teoria interpretativa da verdade. Davidson tampouco intenta eliminar a camada intensional do significado; o que se busca é evitar a sua reificação. Uma outra parte da tese se debruça sobre o esforço de acomodar na teoria um conjunto de fenômenos linguísticos próprios das línguas naturais: expressões sensíveis ao contexto, como pronomes pessoais e demonstrativos, que forçam a relativização do predicado de verdade às situações de uso das sentenças; quantificação restrita; sentenças com verbos de ação e que descrevem relações causais entre eventos; contextos opacos criados por sentenças com verbos de atitude proposicional, e a dificuldade de tratar esses contextos sem introduzir entidades intensionais. Examino também aspectos fundacionais da semântica de Lepore \& Ludwig, que, sem dúvida, amplia significativamente o escopo de fenômenos linguísticos que podem ser explicados por uma teoria motivada pelo projeto de Davidson. No método dos autores, é estabelecida, entre outras condições, seguindo Davidson, que não basta saber o conteúdo informacional expresso pelos axiomas de uma teoria da verdade. É preciso saber também quais conteúdos os axiomas veiculam. Isto é, tem-se que saber os sentidos dos axiomas. Ao sistematizarem na forma de uma teoria esse conhecimento, eles associam, por meio de uma lista, um sentido/intensão a cada axioma. Para cada expressão da linguagem objeto deve haver um axioma na teoria, e o sentido desse axioma deve ser conteúdo de conhecimento do semanticista/intérprete para que ele seja capaz de empregar a teoria-T para interpretar as expressões subsentenciais e as sentenças da linguagem objeto. Se minha observação estiver correta, na estrutura da teoria dos autores acaba por ocorrer a reificação dos sentidos dos axiomas, o que seria forte indicação de que a semântica que constroem não cumpre o propósito de ser uma teoria imune à introdução de entidades intensionais. Além disso, esta associação de um conteúdo semântico a cada axioma via quantificação, parece implicar uma questão mais grave: o assinalamento de objetos intensionais às expressões da linguagem objeto. Desse modo, se minhas ponderações estiverem corretas, a semântica dos autores parece não se configurar como uma alternativa às teorias neo-fregeanas, no sentido de cumprir o que estas fazem, sem que, na sua estrutura, tenha que postular entidades intensionais.

Palavras-chave: Donald Davidson; semântica; significado; verdade; intensão; reificação. 


\begin{abstract}
NAVARRO. M, P, A. The Davidsonian Project of a Compositional Semantics for Natural Languages. 2017 - Dissertation (PhD), p.238 - Faculdade de Filosofia, Letras e Ciências Humanas, Universidade de São Paulo, São Paulo, 2017.
\end{abstract}

In this dissertation I carry out a sistematic exposition and examination of Donald Davidson's semantic project to construct a compositional theory of meaning for natural languages by exploring the recursive structure of an interpretative truth theory à lá Tarski. In this strategy, a theory of meaning must be able to capture the general linguistic ability of any speaker of a language to produce and interpret new sentences. The requirement that the theory be compositional is the fundamental criterion that guides Davidson's enterprise and ii is at the basis of the project of elucidating the compositional aspect of meaning via the use of a theory of truth of the Tarskian type. I argue that Davidson's project attempts to lay the groundwork for a research program on natural language semantics which, while not hegemonic in the field and viewed with skepticism by some, is the only example so far of an attempt to systematically illuminate the compositional aspect of the meanings of broad fragments of natural languages without a direct appeal to abstract entities associated with the expressions of a language, such as properties, senses, propositions, intensions, etc. Two topics about the project received detailed attention. Firstly, I focus on issues of philosophical foundations raised by the proposal. I approach Davidson's objections to theories that quantify over meanings by discussing the problems he identifies in analyzes that reify the intensional layer of the meanings of the expressions of a language, especially neo-Fregean systems, such as those proposed by Rudolf Carnap and Alonzo Church. Based partly on Davidson's criticism, which is scarcely examined in the literature, and without which there is a risk of a misinterpretation of the ambitions of the project, I maintain, along with the neo-Davidsonian semanticists Ernie Lepore \& Kirk Ludwig $(2005$; 2007), that Davidson does not attempt to provide a semantics which is characterized by substituting or reducing a theory of meaning to a truth theory. The idea is that a compositional theory of meaning can be presented as a body of knowledge about an interpretive truth theory. Davidson does not seek to eliminate the intensional layer of the expressions. What is sought is to avoid its reification. Another part of the thesis focuses on the effort to accommodate in the theory a set of linguistic phenomena proper to natural languages: context-sensitive expressions such as personal and demonstrative pronouns, which force the relativization of the truth predicate of to the contexts of use; Restricted quantification; Sentences with action verbs that describe causal relationships between events; Opaque contexts created by sentences with propositional attitude verbs, and the difficulty of dealing with these contexts without introducing intensional entities. I also examine the foundational aspects of Lepore \& Ludwig's semantics, which undoubtedly widens the scope of linguistic phenomena that can be explained by a theory motivated by Davidson's project. In the authors' method, it is established, among other conditions - following Davidson"s approach - that it is not enough to know the informational content expressed by the axioms of a theory of truth. It is also necessary to know what content the axioms convey. That is, one has to know the meanings of the axioms. By systematizing this knowledge in the form of a theory, they associate, through a list, a sense/intension to each axiom. For each expression of the object language there must be an axiom in the theory, and the meaning of this axiom must be the content of the semanticist / interpreter's knowledge so that he is able to employ a truth theory to interpret the subsentential expressions and the sentences of the object language. If my observation is correct, in the structure of the authors" theory the reification of the meanings of the axioms occurs, which would be a strong indication that the semantics they construct does not fulfill the purpose of being a theory immune to the introduction of intensional entities. Moreover, this association of a semantic content to each axiom via quantification seems to imply a more serious question: the signaling of intensional objects to the expressions of the object language. Thus, if my considerations are correct, the semantics of the authors seems not to be configured as an alternative to neo-Fregean theories, in the sense of fulfilling what they do, without in the structure of the theory having to postulate intensional entities.

Key-words: Donald Davidson; semantics; meaning; truth; intension. 


\section{SUMÁRIO}

\section{CAPÍTULO I: CONDIÇÕES PARA UMA TEORIA DO SIGNIFICADO E DEBILIDADES}

DE ANÁLISES VIGENTES

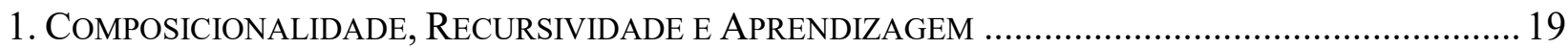

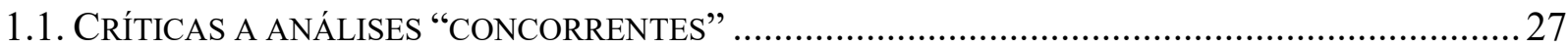

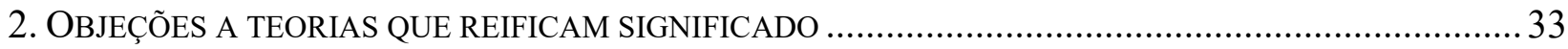

2.1. O ARGUMENTO DO COLÁPSO LÓGICO-SEMÂNTICO EM “TRUTH AND MEANING” .....................36

2.1.1 OBJEÇÃO À OBJEÇÃO DE LEPORE \& LUDWIG AO ARGUMENTO ...................................... 42

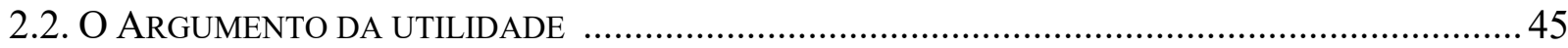

2.2.1. O ATAQUE À UTILIDADE DA REIFICAÇÃO EM “TRUTH AND MEANING" .............................46

2.2.2. O ESQUEMA- $M$ E A CONTRIBUIÇÃO DE LEPORE \& LUDWING ........................................ 50

CAPÍTULO II: A CONCEPÇÃO SEMÂNTICA DE VERDADE DE ALFRED TARSKI E AS OBJEÇÕES DO LÓGICO A SUA APLICAÇÃO ÀS LÍNGUAS NATURAIS

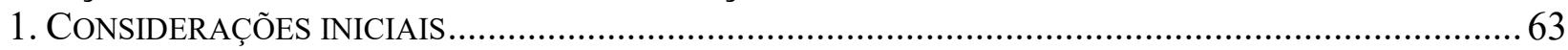

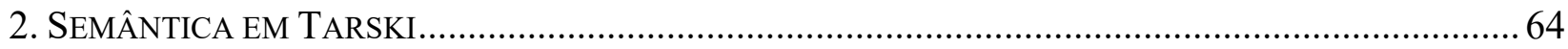

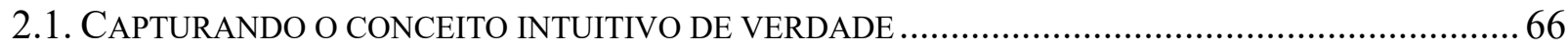

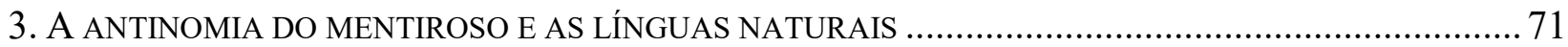

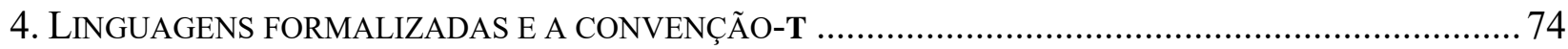

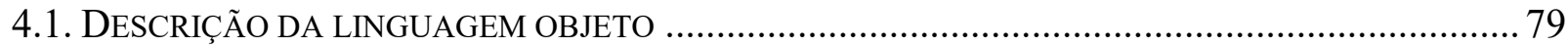

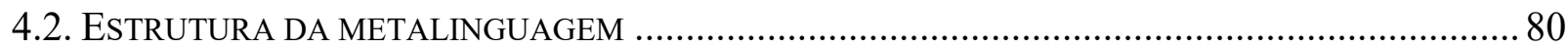

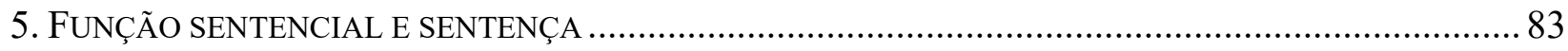

6. A DEFINIÇÃO DE VERDADE EM TERMOS DO CONCEITO DE SATISFAÇÃO ….................................... 85

7. AS LÍNGUAS NATURAIS NÃO SERIAM FORMALMENTE ESPECIFICÁVEIS? ..................................... 95

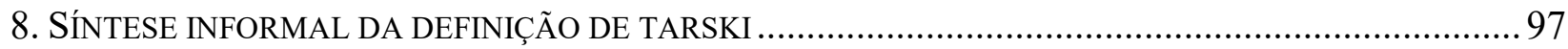

\section{CAPÍTUlO III: A PARTE PROPOSITIVA DO PROJETO DE DAVIDSON E DESAFIOS} POSTOS

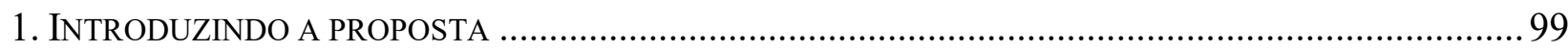

2. CAPTURANDO O COMPORTAMENTO SEMÂNTICO DE ALGUMAS EXPRESSÕES ............................. 105

2.1. ELEMENTOS SENSÍVEIS AO CONTEXTO E REVISÃO DA CONVENÇÃO-T …............................ 105

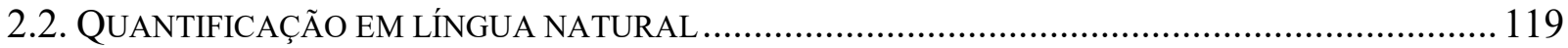

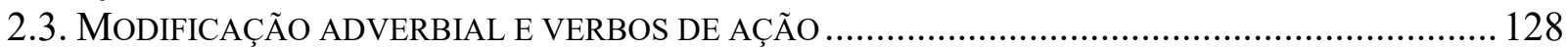

2.3.1. FORMA LÓGICA DOS VERBOS DE AÇÃO E OS ADVÉRBIOS COMO PREDICADOS..................129

2.4. QUANTIFICAÇÃO, ONTOLOGIA E FORMA LÓGICA …......................................................... 140

2.5. DESAFIOS OU LIMITES À SOLUÇÃO EM TERMOS DE EVENTOS ........................................... 148

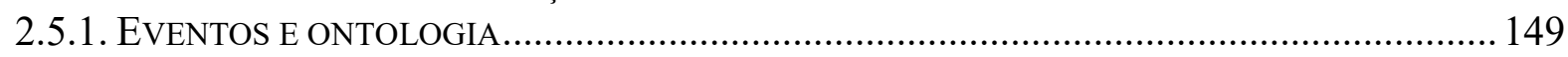

2.5.2. O CRITÉRIO DE DAVIDSON E A OBJEÇÃO DE QUINE .................................................... 152

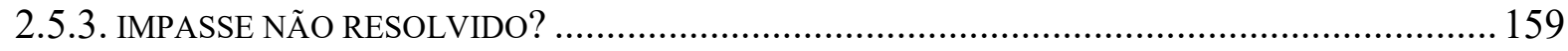

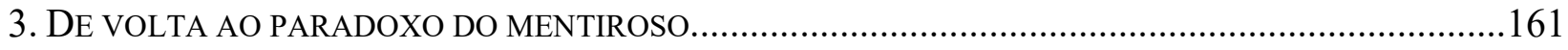

4. AUSÊNCIA DE ESTRUTURAS EXATAS NAS LÍNGUAS NATURAIS: UM PROBLEMA DE FATO?...........164

CAPÍTULO IV: CONTEXTOS OPACOS: PEDRA NO CAMINHO DE UMA SEMÂNTICA DAVIDSONIANA? 167

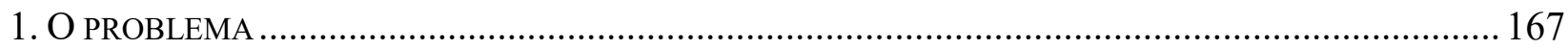




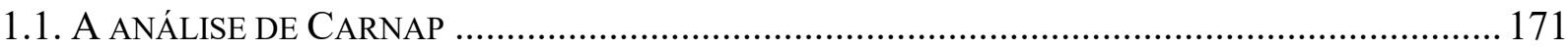

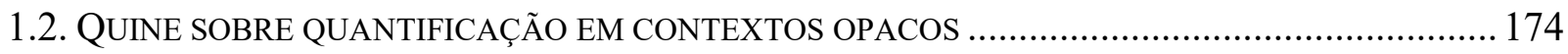

2. O MÉTODO PARATÁTICO DE DAVIDSON PARA O DISCURSO INDIRETO ....................................... 184

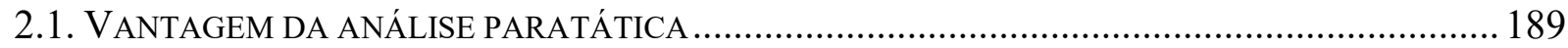

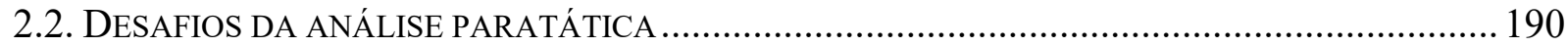

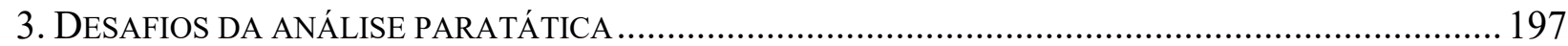

\section{CAPÍTULO V: O PAPEL DE UMA TEORIA DA VERDADE NO CORPO DE UMA} TEORIA DO SIGNIFICADO 198

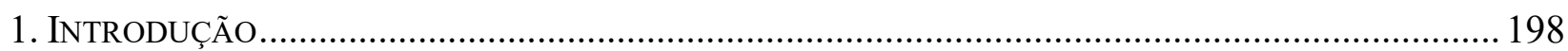

2. ALGUMAS ESTRATÉGIAS PARA BARRAR TEORIAS-T NÃO INTERPRETATIVAS ...........................200

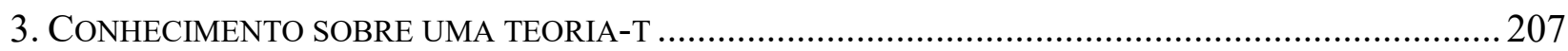

4. A TEORIA EXPLÍCITA DO SIGNIFICADO EM LEPORE \& LUDWIG: A REIFICAÇÃO VOLTANDO PELA

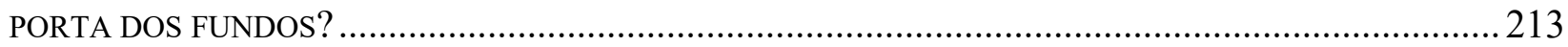

5. EXPLORAÇÕES PRELIMINARES DE UM TÓPICO PARA UM FUTURO ESTUDO: O MÉTODO DO INTÉRPRETE RADICAL COMO RECEITUÁRIO PARA ENFRENTAR A REIFICAÇÃO .............................217

$\begin{array}{ll}\text { CONCLUSÃO } & 226\end{array}$

Apêndice: Notação das Constantes Lógicas 231

$\begin{array}{ll}\text { Bibliografia } & 232\end{array}$ 


\section{INTRODUÇÃO}

A presente tese pretende realizar uma exposição e investigação sistemáticas do projeto semântico do filósofo estadunidense Donald Davidson de construir uma teoria composicional do significado para as línguas naturais explorando a estrutura recursiva de uma teoria interpretativa da verdade de tipo tarskiana. O projeto de Davidson, em virtude da sua intencionalidade e métodos empregados, configura-se como uma teoria do significado nos marcos da semântica formal das línguas naturais, disciplina hoje bastante consolidada, mas ainda em conformação no período em que Davidson apresenta seus artigos programáticos, e cujo estabelecimento como campo de investigação próprio se deve em parte aos trabalhos do filósofo. A Semântica Formal caracteriza-se como uma displina que emprega técnicas oriundas da lógica simbólica e da matemática para elaborar teorias do significado precisas e rigorosas para as línguas naturais ou linguagens formais. Motivado pelo robusto desenvolvimento das lógicas simbólicas na primeira metade do século vinte, num conjunto de textos publicados entre as décadas de 60 e 70, mas também em textos mais tardios, Davidson elaba e refina o projeto de fornecer o que ele cunhou de uma "explicação construtiva do significado das sentenças" (1990 [1965]: 3) de uma língua natural: uma teoria que, mediante uma estrutura recursiva, busca exibir como o significado de uma sentença depende do significado de suas partes. Sob este enfoque, uma teoria do significado para as línguas naturais deve ser capaz de capturar a capacidade linguística geral que qualquer falante de uma língua possui de produzir e interpretar novas sentenças. O requerimento de que uma teoria do significado seja composicional constitui o critério fundamental que orientará o empreendimento de Davidson. Esta prescrição está na base do projeto de elucidar o aspecto composicional do significado em língua natural via o emprego de uma teoria da verdade de tipo tarskiana. Procurarei mostrar que o projeto de Davidson lança as bases de um programa de pesquisa em semântica das línguas naturais que, embora não hegemônico no campo e visto com ceticismo por alguns, é o único exemplo até o momento de uma tentativa de iluminar de forma sistemática o aspecto composicional do significado de amplos fragmentos e fenômenos das línguas naturais sem um apelo direto a entidades intensionais associadas às expressões de uma linguagem, como propriedades, sentidos, proposições, etc.

Uma ideia crucial do projeto é que para uma semântica formal que forneça análises satisfatórias das expressões de uma língua natural não é necessário postular objetos intensionais como os significados das sentenças e das unidades subsentencias. Contudo, na perspectiva de Davidson, evitar o apelo a significados como entidades abstratas assinaladas às expressões de uma linguagem não se caracteriza como um projeto eliminacionista, no sentido de descartar a noção de significado como conteúdo semântico-informacional veiculado pelas sentenças de uma língua. Davidson acredita que seu sistema não dispensa uma distinção entre referência e sentido/intensão, 
mas que essa distinção não implica uma ontologia de entidades intensionais ao lado das entidades denotadas e quantificadas por uma linguagem. A proposta apresenta problemas, limitações e desafios que têm de enfrentar, como é de se esperar de um projeto relevante, instigador, em elaboração, sujeito a teste e que demanda inovações técnicas não necessárias em uma semântica para linguagens formalizadas. No entanto, muitas das debilidades e problemas filosóficos que alguns críticos do projeto sustentam ter nele identificado resultam de leituras equivocadas sobre as suas motivações, finalidades, e a forma que teoria assume. Interpretações essas que nos impedem de ter uma compreensão justa do aspecto nuclear do projeto davidsoniano: o papel desempenhado por uma teoria da verdade na construção de uma teoria do significado.

Davidson propõe que uma teoria da verdade de tipo tarskiana, cumprindo certas condições, pode ser posta a serviço de uma teoria composicional do significado. O projeto não consiste, como posições preciptadas sugerem, em substituir uma teoria do significado por uma teoria da verdade, sob o argumento de que significado é uma noção muito vaga, imprecisa, incoerente, obscura, e que deve ser substituídade pela noção de ,verdade ${ }^{e e}$ em uma teorização sistemática e formal da interpretação em língua natural. O projeto busca uma descrição das línguas naturais e das suas propriedades semânticas composicionais, e não uma reconstrução ou aperfeiçoamento das estruturas das línguas. Davidson compreende o seu programa semântico apenas como uma nova abordagem dada a um problema tradicional na filosofia analítica, que remonta ao menos até Frege, continuando a ser perseguido por outros filósofos e semanticistas: a natureza composicional do significado. Explorando a estrutura recursiva de uma teoria da verdade, almeja-se iluminar o significado das sentenças de uma língua. Da perspectiva de Davidson, seu sistema semântico é concebido como estando no marco tradicional de investigar e fornecer uma explicação da composicionalidade do significado: de como as sentenças compõem um todo significativo, i.e., de como o significado do todo depende dos significados das partes que o compõem. ${ }^{1}$ Davidson se preocupa em pontuar esta posição mais de uma vez em seus textos programáticos, mas também em artigos mais tardios. Como será ilustrado fundamentalmente com fontes textuais dos principais trabalhos do filósofo nos quais ele desenha o seu projeto e responde a críticas, Davidson sustentará o uso de uma teoria da verdade no estilo de Tarski - com modificações para empregá-la no tratamento das línguas naturais - como um veículo de uma teoria formal do significado, como um meio indireto de iluminar o significado

\footnotetext{
${ }^{1}$ Ver também Ludwig (2015) para uma defesa desta posição interpretativa.
} 
das sentenças de uma língua. Parte da suspeita que frequentemente se tem quanto ao projeto decorre de uma leitura equivocada de como uma teoria da verdade seria interpretativa: a ideia de que o projeto espera fornecer uma caracterização de um predicado de verdade para uma língua particular que também consistirá em uma caracterização do significado. Contudo, não é esse o propósito. A teoria da verdade não é identificada com a teoria do significado, como a maioria dos críticos sugere; é parte dela. O que não exclui, presumivelmente, o seu papel essencial na semântica proposta. Como Davidson explicita bem em "Reply to Foster" (1976), eliminando possíveis ambiguidades de passagens em textos anteriores que sugerem uma posição de substituição ou de redução de uma teoria do significado a uma teoria da verdade, aquela consiste em um corpo de conhecimento sobre a última. Esse corpo deve especificar, além das restrições formais impostas a uma teoria da verdade inspirada em Tarksi, o que precisamos saber a cerca dela que nos colocará na posição de empregá-la como uma teoria interpretativa para uma linguagem objeto. Como o objetivo de uma teoria do significado é compreender o significado das sentenças de uma língua em uso, um problema essencial será fornecer condições sobre a teoria fortes o suficiente para garantirem que a teoria possa ser aplicada para a interpretação. Nesse sentido, também é essencial fornecer condições a serem cumpridas para que as sentenças- $\mathrm{T}$ de uma teoria interpretem as sentenças de uma linguagem objeto, i.e., para que as condições de verdade geradas composicionalmente sejam interpretativas. Davidson, nesse sentido, inverte a perspectiva de Tarski. O desafio será justamente de especificar as condições suficientes a serem cumpridas por uma teoria da verdade para que ela seja empregada na interpretação das sentenças de uma língua natural.

A proposta de Davidson de como perseguir o projeto de uma teoria do significado é fortemente motivada por duas críticas a teorias ou análises semânticas em voga no momento em que ele esboça seu projeto. Uma das críticas é destinada a análises de construções em línguas naturais que, por implicarem a existência de um vocabulário infinito, e, portanto, um conjunto infinito de primitivos semânticos, não representariam adequadamento a habilidade de um falante em produzir e interpretar as sentenças de sua língua. O argumento de Davidson repousa sobre a constatação de que, ainda que um intérprete possua em potencial a capacidade de produzir e interpretar um conjunto infinito de sentenças, ele é um ser finito e com capacidades finitas. Essa condição induziria como hipótese mais plausível, sugere o filósofo, a ideia de que essa capacidade seja descrita como um procedimento gerativo com base em um número finito de termos básicos e de regras recursivas de composição. A incompatibilidade de uma teoria com essa condição poderia suscitar, como consequência mais danosa, a descrição de uma língua que a apresente como impossível de ser aprendida. A segunda objeção consiste em um ataque a teorias que apelam a significados como entidades, i.e., que quantificam sobre significados na tentativa de explicar a 
semântica das expressões linguísticas. De mode geral, tais teorias assumem entidades como propriedades, conceitos individuais, proposições, etc., como podendo ser designadas por expressões e sentenças de uma linguagem. Davidson tem como adversárias, no momento em que escreve os textos programáticos do seu projeto, teorias semânticas cujos alvos de investigação, em primeiro plano, incluem linguagens formais, assim como a extensão dessas linguagens incorporando noções intensionais, como necessidade e possibilidade, e, em um segundo plano, fragmentos das línguas naturais. Fundamentalmente, dois sistemas referidos como neo-fregeanos. A semântica de Rudolf Carnap, conhecida como o Método de Intensão e Extensão, elaborada em especial nos livros Introdution to Semantics, de 1941, e Meaning and Necessity, de 1947, em que nomes, descrições definidas, predicados e sentenças são classificados como designadores (designators) aos quais estão associadas entidades abstratas, como conceitos individuais, propriedades e proposições; e a semântica de Alonzo Church, formulada nos textos "The Need of Abstract Entities in Semantic Analysis" e "A Formulation of the Logic of Sense and Denotation", ambos de 1951, que envolve hierarquias de expressões e entidades, com entidades em cada nível servindo de sentidos de algumas expressões e referentes de outras expressões. O tratamento em detalhe dessas duas semânticas está além do escopo desta tese, pois presumivelmente isso demandaria um estudo comparativo que excede o propósito deste trabalho, que é de investigar detalhadamente a semântica de Davidson. Mas em passagens que entendermos como necessário, remeteremos a elas, em especial quando isso for essencial para avaliar a solução alternativa de Davidson para as sentenças de atitude proposicional. Uma referência direta a uma semântica específica adversária, entretanto, nem sempre será essencial para os argumentos de Davidson contra a reificação, como ficará claro no primeiro capítulo. Os seus dois argumentos principais, se corretos, possuem uma generalidade que se destina a toda teoria semântica que em algum momento reifica o significado, especificando regras que assinalam entidades intensionais a expressões de uma linguagem.

As objeções de Davidson, portanto, estão alicerçadas em dois argumentos. Chamarei eles de argumento de objeção lógico-semântica e argumento da utilidade. O primeiro deles intenta mostrar que tomar sentenças como se referindo aos seus significados conduz necessariamente a um colapso ontológico, reduzindo o significado das sentenças de uma língua a apenas dois. O significado das sentenças verdadeiras e o significado das sentenças falsas. Davidson intenta demonstrar esse colapso por meio de um argumento. Basicamente a conclusão a que nos leva o argumento é que, se um semanticista toma por premissa na sua teoria a pressuposição de que sentenças podem denotar ou se referir aos seus significados, então ele estará incontornavelmente comprometido com a proposição falsa de que sentenças com o mesmo valor de verdade serão sinônimas. Conclusão essa 
presumivelmente insustentável. O segundo argumento - contra a utilidade teórica da reificação procura demonstrar que recorrer a significado como entidade não é nem necessário nem suficiente para levar a cabo a tarefa de uma teoria semântica sistemática. Ou seja, não teria utilidade explicativa como um método para a análise do significado em língua natural. Esses dois argumentos que conformam a objeção contra o apelo a significados como objetos intensionais postulados por uma teoria são expostos na primeira parte do texto "Truth and Meaning", precedendo o esboço do projeto davidsoniano, que é exposto na segunda parte do texto. Muito da incompreensão e interpretações equivocadas acerca da proposta elaborada por Davidson tem sua origem no desconhecimento do que chamo de aspecto crítico do projeto davidsoniano - i.e, em que a reificação do significado é atacada - ou no erro de não perceber a importância desta parte para compreender a razão de Davidson entrever no trabalho de Tarski sobre a verdade um instrumento para se construir uma teoria semântica. Por essa razão, argumentarei no capítulo I que, sem um entendimento do papel desempenhado pela parte negativa na conformação do projeto davidsoniano, é fácil para o intérprete incorrer no erro de não reconhecer que Davidson persegue nos textos inaugurais da sua teoria, antes de tudo, uma resposta para a pergunta "O que é ter uma teoria do significado para uma língua natural?" e não para a pergunta geral “O que é significado?”. A mudança de perspectiva não é no sentido de definir significado em termos de verdade, mas sim de especificar as condições a serem cumpridas por uma teoria do significado que incorpora uma teoria da verdade. A mudança de foco é em relação à pergunta que guia o esboço do projeto. Há em Davidson um desconforto explícito com qualquer teoria que reifica significado, e que se constrói sobre essa concepção, porque, o que é crucial na argumentação de Davidson, ao cabo elas fracassam na tarefa de fornecer uma teoria sistemática. É à luz desta crítica que uma interpretação do projeto davidsoniano pode fazer justiça ao que Davidson se propunha. O otimismo de Davidson com o trabalho de Tarski consiste justamente no fato de ele, entende o filósofo, viabilizar a conformação de uma teoria composicional do significado sem apelar à reificação do significado e sem comprometimento prévio com qualquer concepção pressuposta a respeito da natureza do significado, além do seu aspecto composicional. Se essa é uma maneira convincente de se ler o trabalho de Tarski e se o projeto de Davidson é capaz de cumprir o que se propõe são questões de outra ordem, do âmbito de uma avaliação crítica do projeto, tarefa que em parte enfrentaremos aqui também. Mas no que diz respeito à interpretação, há suficientes evidências textuais de que é da maneira argumentada acima que Davidson entende e situa o seu projeto. No que tange às posições acima, nossa posição está bastante em consonância com a linha interpretativa sustentada por Lepore e Ludwig $(2005 ; 2007)$. 
Em vista da centralidade, portanto, da parte crítica do projeto de Davidson - contida essencialmente em dois textos conceitualmente contectados, a saber, "Theories of Meaning and Learnable Languages" (1965) e "Truth and Meaning" (1967) - para uma interpretação adequada do projeto e em consonância com a maneira que o próprio filósofo concebe a sua proposta construtiva, dedicarei o primeiro capítulo da tese às objeções de Davidson a possíveis teorias semânticas adversárias. Desta crítica emergem condições essenciais a serem cumpridas por qualquer teoria do significado que se pretende satisfatória. Com isso espero mostrar como que uma apreciação profunda da parte crítica é imprescindível para iluminar corretamente estas condições e o papel que cumprem na configuração da forma geral que uma teoria do significado deve assumir.

O capítulo I está dividido em duas seções. Na primeira seção, examino as objeções que Davidson levanta contra análises que violam o requerimento da finitude e representam as línguas naturais como impossíveis de serem aprendidas. Na segunda seção, concentro-me nas objeções elaboradas em "Truth and Meaning" a uma teoria que apela à reificação dos significados no tratamento composicional do significado para a linguagem natural. O argumento do colapso lógicosemântico consiste na tentativa de demonstrar que a adoção da hipótese de que sentenças podem ser descritas como termos singulares complexos que se referem aos seus significados conduz inevitavelmente à conclusão falsa de que todas as sentenças com o mesmo valor de verdade são sinônimas, colapsando o significa das sentenças em apenas dois: o referido pelas sentenças verdadeiras e o referido pelas sentenças falsas. Com o argumento da utilidade intenta-se demonstrar que o comprometimento com significados como entidades não é nem necessário nem suficiente em uma teoria composicional do significado. Quanto ao argumenta do colapso, procurarei defendê-lo contra a objeção de Lepore \& Ludwig (2010[2007]), segundo a qual o argumento pressuporia o que pretende provar. No que diz respeito ao argumento da utilidade, examinarei as passagens de Davidson contra a utilidade teórica de uma ontologia de significados, mas também me debruçarei sobre a continuação dessa objeção nos trabalhos de Ernest Lepore e Kirk Ludwig. Isso porque estes comentadores não apenas interpretam esta posição de Davidson como a mais robusta contra a reificação, mas empreendem um refinamento e aprofundamento deste argumento, dando a ele não somente uma forma que exibe com mais rigor o seu apelo e abrangência, mas também o fortalecendo. É importante aqui elucidar alguns pontos sobre a opção de ter por eixo principal no capítulo I o texto "Theories of Meaning and Leanable Languages" (1963) e a primeira parte de "Truth and Meaning" (1967), percorrendo com afinco os argumentos neles contidos. Em primeiro lugar, em virtude de ambos os textos serem os principais artigos programáticos do projeto de Davidson e onde se estabelecem as condições gerais para regular a conformação de uma teoria do significado. Em segundo lugar, porque, como já pontuamos nesta introdução, interpretações 
equivocadas sobre o projeto têm resuldado, em grande medida, de uma ausência de referência ao contexto dos trabalhos de Davidson. Por exemplo, de modo geral as críticas se apoiam em referência a algumas passagens, sobretudo de "Truth and Meaning", que, isoladas do contexto do artigo e da sua ligação com "Theories of Meaning and Learnable Languages" e também textos subsequentes, podem induzir a leitura de que Davidson intenta identificar uma teoria do significado com uma teoria da verdade. Para compreender melhor as aspirações do projeto é mandatório, entendo, percorrer as linhas argumentativas de continuidade entre ambos. Somado a isso, via o emprego e diálogo com as fontes textuais, espero mostrar a correção da nossa versão interpretativa. Além desses dois textos, haverá passagens em que remeteremos a outros textos em que os temas do capítulo I reaparecem.

No capítulo II, realizo uma exposição pormenorizada da definição de verdade elaborada por Alfred Tarski. Por causa do papel indispensável que uma teoria da verdade de tipo tarskiana cumpre no projeto davidsoniano de uma teoria composicional do significado, resulta incontornável dedicar uma atenção detalhada a ela. São duas as razões essenciais para dedicar um capítulo à concepção semântica de verdade em Tarski. Em primeiro lugar, uma apreciação justa e crítica do projeto de Davidson não pode ser efetivada sem uma familiaridade mínima com o maquinário técnico empregado por Tarski e essencial para a conformação da sua definição. Em segundo lugar, é somente em posse desse maquinário que o leitor pode apreciar as vantagens técnicas e filosóficas que Davidson enxerga no edifício construído por Tarski. Por isso, percorro no capítulo as etapas que avalio cruciais na confecção da definição de verdade. Por fim, exponho também características que Tarski acredita identificar nas línguas naturais e que, na sua perspectiva, inviabilizam a aplicação da sua definição a elas. Fundamentalmente, o fato de uma língua natural possuir os meios de se referir aos próprios objetos linguísticos que a constituem, incluindo suas sentenças, conter seu próprio predicado de verdade e outros termos semânticos, e não apresentar uma estrutura sintática exata. Para o leitor já suficientemente familiarizado com o método de Tarski e com seu cetismo quanto a extrapolar seu projeto para a linguagem coloquial, não é premente percorrer este capítulo, e saltar já para o capítulo III não incorrerá em perdas e descontinuidades comprometedoras. Todavia, para aquele leitor que, por ventura, entrará em contato com a definição de verdade de Tarski pela primeira vez via o presente trabalho, recomendo fortemente debruçar-se sobre o capítulo II. A não apreciação dele por esses leitores poderá comprometer o entendimento de aspectos nucleares do projeto de Davidson, e, por conseguinte, o acompanhamento dos temas abordados nesta tese.

No capítulo III, examino alguns desafios, problemas e limites suscitados pelo projeto de fornecer uma semântica composicional tendo por veículo uma teoria da verdade de tipo tarskiana. 
Soluções são demandas para tais impasses se pretendermos que o projeto tenha algum sucesso. Este capítulo concentra-se, prioritariamente, em fenômenos linguísticos próprios das línguas naturais para os quais Davidson chama a atenção, e para alguns dos quais ele propõe um tratamento e apresenta contribuições nos marcos do projeto. O propósito não será de argumentar que há uma solução satisfatória para cada um dos problemas exibidos, mas antes de examinar a natureza de cada problema, dando destaque a soluções elaboradas por Davidson, comentadores e críticos. Quando possível, também indicar limitações de algumas explicações e sugerir algumas saídas. Na primeira parte do capítulo (seções 1 e 2) abordo a questão de como dar um tratamento a expressões e construções das línguas naturais, incorporando-as a uma semântica davidsoniana, de maneira a descrever adequadamente o papel composicional que cumprem nas sentenças. Entre elas destacamos as seguintes: pronomes pessoais e demonstrativos; quantificadores; modificadores adverbiais e sentenças com verbos de ação ou que estabelecem relações causais. Tais fenômenos exigirão modificações importantes na forma da teoria para serem acomodados por ela, e são estas alterações que focaremos. No percurso de análise dessa constelação de fenômenos, duas questões inevitavelmente emergem: o problema das formas lógicas dessas construções e a ontologia nelas embutidas. Por isso, subseções um pouco densas, em virtude da natureza desses temas, serão a eles dedicadas. Na segunda parte (seção 3) retomo os desafios já pontuados por Tarski que colocam sérias dúvidas quanto à possibilidade de aplicar uma teoria da verdade à linguagem coloquial. Revisito a antinomia do mentiroso e sua causa: os fragmentos de uma linguagem coloquial que contenha seu próprio predicado de verdade. E também rediscuto a tese de que as línguas naturais não possuiriam estruturas sintáticas exatadas. Ambos os fenêmenos são mobilizados por Tarski, recordem, como evidências bastante conclusivas de que o empreendimento de fornecer uma definição formal consistente de verdade para as línguas naturais resulta estério. O que se problematiza na seção 3, em interlocução com sugestões do próprio Davidson, é justamente se, uma vez existentes os fenômenos indicados por Tarski, eles seriam suficientes para uma conclusão cética quanto ao sucesso de um projeto semântico como o de Davidson.

No capítulo IV, trato de um tópico bastante desafiador para a teoria do significado de Davidson: a semântica dos contextos sentenciais opacos. Essencialmente, são ditos opacos ou oblíquos contextos nos quais a intersubstituição de expressões coextensivas ou sentenças com o mesmo valor de verdade fracassam. Casos típicos de tais fenômenos são sentenças cujos verbos principais indicam uma atitude proprosicional, i.e., sentenças com expressões verbais como „,acreditar que ${ }^{e e}$, „duvidar que ${ }^{e e}$, ,saber que ${ }^{e e}$, etc. Outros casos emblemáticos de opacidade são sentenças de discurso indireto e com operadores modais, tais como „necessariamente ${ }^{e e}$ „possivelmente ${ }^{e}$. Como procuro pontuar detalhadamente no capítulo, sentenças opacas criam 
dificuldades para uma semântica que evita o apelo direto a entidades intensionais como proposições, propriedades, sentidos, etc. O sucesso de tal teoria é dependente da capacidade dela fornecer uma análise alternativa satisfatória desses contextos na qual não há comprometimento com a tese de que as sentenças complementos de verbos de atitude proposicional ou sob o escopo de operadores modais se referem ou denotam seus sentidos/intensões, como nas soluções ditas proposicionalistas, de tradição fregeana. Davidson fornece sua análise das sentenças de discurso indireto e sugere que ela possa ser generalizada para outros verbos. No capítulo IV, então, examinamos esta proposta, que intenta evitar tratar sentenças de atitude proposicional como estabelecendo uma relação entre falantes e proposições. Identificamos suas vantagens e alguns impasses que ela origina, dando destaque a possíveis objeções a ela. Mas também abordo duas alternativas anteriores as de Davidson, com as quais sua solução dialoga e cujas dificuldades que suscitam, sugiro, o levam a procurar outra saída. Tais análises são as de Rudolf Carnap, delineada em Meaning and Necessity (1943) e a de W. V. Quine, elaborada em Word and Object (1960). Estas propostas são classificadas na literatura como estratégias sentencialistas, por tratarem os verbos de atitude proposicional como estabelendo uma relação entre falantes e sentenças ou enunciados. A princípio, os contextos intensionais seriam abordados em uma seção do capítulo III. Todavia, por causa da riqueza e importância do debate em filosofia da linguagem acerca deste tópico, o que seria uma seção acabou se estendendo, e tomando o corpo de um capítulo. Nada mais justo à relevância do tema e aos desafios que ele coloca a uma semântica austera como a de Davidson, do que dedicar um capítulo a ele.

$\mathrm{O}$ capítulo $\mathrm{V}$, último da tese, aprofunda o exame sobre o lugar ocupado por uma teoria da verdade no corpo de uma teoria composicional do significado, concentrando-se, para tanto, no debate em torno da questão acerca do que um teórico precisa saber sobre uma teoria interpretativa da verdade, de maneira a empregá-la para interpretar adequadamente as sentenças de uma língua. Um olhar apropriado sobre este tópico é crucial para se comprender a relação entre uma teoria-T e o conhecimento dela na semântica de Davidson. Abordando explicações que Davidson contempla para essa questão, espero cumprir duas tarefas neste capítulo. Em primeiro lugar, argumentarei, em coro com Lepore \& Ludwig (2005), que a objeção de Foster (1976) - segundo a qual qualquer descrição do conhecimento acerca de uma teoria da verdade que garante o seu emprego na interpretação extrapolaria as próprias condições impostas por Davidson, demonstrando, com isso, que elas se revelam insuficientes para o sucesso da sua teoria - resulta de uma leitura equivocada do projeto que Davidson elabora. Na verdade, espero ainda mostrar, com isso, que as condições a mais que o próprio Foster propõe introduzir, não somente não são incompatíveis com as de Davidson, mas por ele também exigidas. Em segundo lugar, examino como Lepore \& Ludwig (2005; 2007) 
identificam uma teoria composicional do significado com um corpo de conhecimento apropriado sobre uma teoria interpretativa da verdade. Procuro argumentar que a forma como os autores sistematizam este conhecimento não me convence de que eles conseguem evitar de incorrerem numa reificação do conteúdo semântico expresso pelos axiomas, ao explicitar como uma condição necessária que o intérprete saiba o que os axiomas significam. A consequência indesejada seria que a teoria de Lepore \& Ludwig, tal como ela aparace nos trabalhos Donald Davidson: Meaning, Truth, language, and Reality (2005) e Donald Davidson's Truth-Theoretic Semantics (2007), acarreta a reificação dos sentidos dos axiomas da teoria da verdade, e, por "contaminação", dos sentidos expressos pelas expressões da linguagem objeto. Desse modo, se minhas ponderações estiverem corretas, a semântica dos autores parece não se configurar como uma alternativa às teorias neo-fregeanas, no sentido de cumprir o que estas fazem, sem que, na sua estrutura, tenha que postular entidades intensionais. Por fim, na seção derradeira do capítulo, apenas introduzo de forma ponorâmica o tópico do intérprete radical e seu papel no projeto de Davidson. O objetivo na seção não é de realizar um exame do intérprete radical tal como proposto por Davidson, de maneira a se posicionar quanto à questão de se ele cumpre o que se propõe. Qualquer conjectura rigorosa sobre o seu sucesso pede um estudo cujo produto seria uma tese inteira só sobre o tema. A introdução do tópico - espera-se - cumpre apenas o papel de fornecer elementos suficientes para que o leitor aprecie o propósito que motiva a introdução do método como parte substancial do projeto semântico de Davidson, e atentar para o fato de que a cisão que Lepore \& Ludwig encampam, a saber, entre o projeto semântico propriamente dito (projeto inicial) e o método do intérprete radical (projeto estendido), têm consequências nocivas, creio, para o tipo de semântica que os autores ambicionam. Independentemente de se as restrições sobre as evidências propostas para a interpretação venham a se revelar insuficientes para garantir um emprego de noções intensionais sem incorrer em reificações, é-me basta claro que, para Davidson, o sucesso da viabilidade de uma teoria do significado deste tipo depende de o intérprete radical cumprir o papel para o qual foi desenhado. Baseado nesta exposição do tema, procuro argumentar - tendo também a seção anterior em perspectiva - que uma semântica como a de Lepore \& Ludwig, dissociada do procedimento do intérprete radical ou de qualquer outro concebível método com o mesmo propósito, fere as ambições cruciais do projeto, ao contrário do que os autores acreditam. Por fim, nas considerações finais, indico alguns tópicos também essenciais para uma avaliação mais integral do projeto, mas que ficaram de fora da tese, quer por razões de espaço e tempo, quer por limitações teóricas nossas no momento. Esses temas serão objetos de futuras investigações que darão continuidade a uma pesquisa que, esperamos, não será interrompida com a conclusão do doutoramento. 


\section{CAPÍTULO I: CONDIÇÕES PARA UMA TEORIA DO SIGNIFICADO ADEQUADA E DEBILIDADES DE ANÁLISES VIGENTES.}

\section{Composicionalidade, recursividade e aquisição.}

Em "Theories of Meaning and Learnable Languages", publicado em $1965^{2}$, Davidson pela primeira vez prepara o cenário para o esboço do seu projeto semântico, que somente aparecerá em suas linhas gerais na segunda parte de "Truth and Meaning" (1967). Ambos os textos são programáticos, articulam um mesmo projeto e complementam um ao outro. ${ }^{3} \mathrm{O}$ propósito central de TMLL é de delinear duas condições gerais necessárias mínimas que uma teoria do significado deve cumprir de modo a se apresentar viável como uma teoria semântica para as línguas naturais. Os dois critérios de adequação de uma teoria são que ela deve descrever as línguas naturais como (i) composicionais e (ii) possíveis de serem aprendidas por um falante. A primeira condição é o critério da composicionalidade e a segunda o critério da aprendizagem. Davidson argumenta em defesa desses dois critérios e os mobiliza como parâmetros para levantar objeções a proeminentes análises semânticas vigentes na época, procurando demonstrar como elas fracassariam em cumprir essas condições. Diz Davidson na introdução de TMLL:

[...] Proponho o que me parece claramente ser uma característica necessária de uma linguagem que pode ser aprendida: deve ser possível dar uma explicação construtiva do significado das sentenças na lingua. Chamo essa explicação de uma teoria do significado para a linguagem, e sugiro que uma teoria do significado que conflita com essa condição, seja apresentada por filósofos, linguistas ou psicólogos, não pode ser uma teoria de uma língua natural; e se ela ignora essa condição ela deixa de tratar de algo central para a concepção de uma língua (1990 [1965]: 3). ${ }^{4}$

O critério da composicionalidade aparece pela primeira vez na passagem acima, e nela Davidson o chama de "explicação construtiva do significado". Uma teoria para uma língua natural deve ser

\footnotetext{
2 "Theories of Meaning and Learnable Languages" foi primeiramente lido em 1964 no evento International Congress for Logic, Methodology, and Philosophy of Science, na Universidade Hebraica de Jerusalém. Foi publicado nos anais de mesmo congresso num volume que saiu pela editora Norh-Holland Publishing Company, Amsterdam, 1965. O artigo reaparece no primeiro volume das obras de Davidson como texto de abertura do livro. A primeira edição de "Inquiries into Truth and Interpretation", primeiro volume das obras, data de 1984. A edição que utilizamos é a de 1990, e consiste na quarta reimpressão do volume. Tais como as edições anteriores, ela foi publicada pela Oxford University Press.

${ }^{3}$ Daqui em diante, frequentemente empregarei as abreviações TMLL para me referir ao artigo "Theories of Truth and Learnable languages" e TM ao texto "Truth and Meaning".

${ }^{4}$ Todas as citações realizadas na presente tese dos trabalhos de Davidson são traduções nossas dos originais em Inglês.
} 
capaz de especificar o significado de cada sentença como uma função do significado de suas partes. Mas evidentemente é no decorrer do texto que Davidson elucida o que ele entende por "explicação construtiva" e o papel teórico que ela cumpre. Prossegue Davidson:

Não é apropriado esperar que considerações lógicas ditem a rota ou o mecanismo de aquisição da linguagem, mas temos o direito de considerar anteriormente ao estudo empírico o que entendermos por saber uma língua, como devemos descrever a habilidade de uma pessoa que aprendeu a falar uma língua. Uma condição natural a impor é que devemos ser capazes de definir um predicado das expressões, baseado somente em suas propriedades formais, que selecione a classe das expressões significativas (sentenças) [...]. Outra e mais interessante condição é que devemos ser capazes de especificar, de um modo que depende efetiva e somente de considerações formais, o que toda sentença significa. [...] Nossa teoria deve nos equipar a dizer, dada uma sentença arbitrária, o que um falante da língua significa com essa sentença [...]. Guiados por uma teoria adequada, vemos como as ações e disposições dos falantes induzem sobre as sentenças da língua uma estrutura semântica. Embora sem dúvida relativizada a tempo, lugar e circunstância, o tipo de estrutura requerida parece identica ou bastante próxima do tipo [de estrutura] dada por uma definição de verdade primeiramente exposta por Tarski, pois tal definição fornece um método efetivo para determinar o que toda sentença significa (i.e., dá as condições de verdade sob as quais ela é verdadeira) [...].

Essas questões aparecem conectadas da seguinte maneira informal com a possibilidade de se aprender uma língua: quando podemos considerar o significado de cada sentença como uma função de um número finito de características da sentença, compreendemos não somente o que há para ser aprendido, mas também entendemos como uma aptidão infinita pode estar contidade em realizações finitas. Pois suponha que uma língua não tenha essa característica; então não importa quantas sentenças um possível falante de uma língua aprenda a produzir e entender, pois haverá outras cujos significados não são dados pelas regras já dominadas. É natural dizer que essa língua não é passível de ser aprendida. Esse argumento depende, certamente, de um número de pressuposições empíricas: por exemplo, que não adquirimos repentinamente em algum ponto a habilidade de intuir o significado das sentenças com base em nenhuma regra. Que cada novo item de vocabulário, ou nova regra de composição, leva algum tempo finito para se aprender; que o homem é mortal (Davidson 1990 [1965]: 7-9).

Muitas proposições são sintetizadas na longa e importante passagem acima, e, por isso, pedem uma análise pormenorizada. A tese central de TMLL é que o papel crucial de uma teoria semântica para uma língua consiste em fornecer uma especificação do que toda sentença de uma língua significa. Mas o que Davidson quer dizer com "especificar" o que toda sentença significa? O requerimento é que uma teoria formal do significado deve determinar, com base somente em considerações sobre a forma das expressões de uma língua, e regras de composições dessas expressões em expressões complexas, o significado de toda possivel sentença gramatical da língua ou do fragmento sob investigação. Em outras palavras, a teoria deve tomar uma forma em que os significados das sentenças descritas por ela sejam deduzidos como teoremas. Essa especificação requer a definição

\footnotetext{
${ }^{5}$ As partes em itálico do fragmento citado são nossas.
} 
de um predicado (que para Davidson será o predicado "x é verdadeiro em L") que se aplica somente às sentenças bem formadas, gramaticais da língua. Mas não somente isso. Pois tal método poderia ser construído apenas fornecendo uma lista de sentenças da língua. Para tornar inteligível como um ser finito domina uma língua com uma infinidade de sentenças não sinônimas, uma solução legítima é explicar essa habilidade como resultante do entendimento do significado das expressões de um vocabulário e de regras de composição que operam na contatenação dessas expressões.

Uma teoria construtiva é uma semântica composicional apresentada numa forma axiomatizada, que capacita quem compreende a linguagem na qual ela é construída para uma língua L a compreender as expressões complexas de L com base na compreensão de seus termos básicos e regras de combinação. O requerimento composicional é uma hipótese bastante robusta e de difícil objeção. Ela é motivada pela observação de que, embora as linguas naturais sejam faladas por criaturas finitas e com um conhecimento linguístico finito, qualquer falante fluente de uma língua natural é capaz, em potencial, de produzir e interpretar com facilidade um conjunto infinito de novas sentenças. Um aspecto significativo do conhecimento linguístico é justamente essa habilidade de produzir e interpretar recorrentemente novas sentenças. Habilidade algumas vezes chamada na literatura de produtividade linguística. Se assumirmos de partida que seres humanos não são criaturas dotadas de capacidades mágicas, então uma explicação racional e científica dessa produtividade línguística consiste em perseguir uma hipótese que possa ser testada. A composicionalidade é uma hipótese deste tipo disponível. De maneira que, se ela for uma propriedade atribuída a nossas línguas e que explica a infinidade em potencial de sentenças significativas que podem ser produzidas, uma teoria que a adota deve perseguir um método sistemático de exibir a composicionalidade do significado. A composicionalidade é estabelecida também como uma condição para uma teoria semântica.

A ideia é de que uma teoria axiomatizada e estruturada como um sistema recursivo pode ser capaz de iluminar um conhecimento semântico que permite que um falante compreenda as sentenças que constituem sua língua: a capacidade que um falante competente de uma língua tem de interpretar e produzir enunciados com base nas propriedades semânticas de suas partes e das estruturas das sentenças. Mas um discernimento essencial deve ser feito aqui, pois é fonte de erros a respeito do projeto davidsoniano. Davidson, com isso, não está sustentando, como uma leitura preciptada da passagem acima pode sugerir, que todo falante de uma língua tem internalizado um conhecimento axiomático da língua que fala, e que ele usa esse conhecimento tácito toda vez que fala e interpreta. É um equívoco pensar que Davidson, ao propor uma teoria axiomática, está comprometido com a perspectiva de que os falantes de uma língua possuem um conhecimento proposicional da teoria. O que Davidson demanda é que a teoria seja capaz, de algum modo, de 
representar, mediante a sua estrutura recursiva, a produtividade linguística do falante de uma língua. Ou seja, ela precisa ser desenhada de modo a "nos equipar a dizer, dada uma sentença arbitrária, o que um falante da língua significa com essa sentença”. O conhecimento que um falante tem de uma língua L o equipa para interpretar as expressões de L e, presumivelmente, não para expressar os fatos metalinguísticos estabelecidos pela teoria. Não se pressupõe que o falante tenha um acesso consciente ao que a teoria estipula. Ao representar adequadamente "ações e disposições dos falantes", i.e., ao atribuir significados às sentenças em conformidade com as disposições interpretativas dos falantes, a teoria infere a partir destas uma estrutura semântica para cada sentença da língua. Na passagem acima, como em outros textos em que Davidson retoma essa ideia com o intuito de esclarecê-la e aprofundá-la, ele não afirma que conhecer uma língua é ter uma teoria internalizada da mesma. Uma teoria de uma língua e o conhecimento dessa teoria em nenhum momento na obra de Davidson são identificados com o conhecimento de uma língua por um falante. O que é demandado é uma modelação teórica de uma habilidade prática (suas disposições) dos falantes de produzir e interpretar enunciados. Em vez de se sustentar a hipótese questonável de que alguém que fala uma língua internalizou em algum nível a estrutura axiomática da teoria, perguntemo-nos se o conhecimento explícito do que a teoria estabelece é sucifiente para representar o aspecto composicional da competência linguística. A teoria procura fornecer, então, um maquinário semântico que esteja em conformidade com hipóteses gerais sobre princípios e condições cruciais da competência linguística, mas a forma cognitiva (psicológica) na qual a competência opera não é tarefa da teoria especificar. Tal subdeterminação não pode ser preenchida pela teoria; ela demanda empreendimentos no campo da psicologia cognitiva, onde de fato podem se dar investigações empíricas sobre as formas dos mecânismos internos da competência e aquisição de linguagem. ${ }^{6}$ Defender que uma teoria semântica deve modelar a competência linguística de um falante/intérprete não sugere automaticamente que o mesmo saiba esta teoria.

Em TMLL uma teoria recursiva é defendida como o melhor meio disponível para dar uma explicação satisfatória do conhecimento composicional que parece operar em nossas disposições

\footnotetext{
${ }^{6}$ Em textos mais recentes Davidson se preocupa em elucidar precisamente sua posição sobre esse tema. Em "The Structure and Content of Truth" (1990), pontua Davidson: "Deve haver certamente algum sentido no qual falante e intérprete internalizaram uma teoria; mas isso não é mais do que o fato de que o falante é capaz de falar como se ele acreditasse que o intérprete o interpretaria do modo que a teoria descreve, e o fato de que o intérprete está preparado para assim o interpretar. Tudo o que devemos exigir de uma teoria da verdade para um falante é que ela seja de tal forma que, se um intérprete tivesse um conhecimento proposicional explícito da teoria, ele conheceria os enunciados de condições de verdade do falante." Neste fragmento está claro que o propósito é construir uma teoria que captura as disposições linguísticas dos falantes, no sentido de representar a habilidade prática dos falantes em interpretar e falar de modo a serem interpretáveis. O que Davidson exigirá de uma teoria da verdade é que, se ela satisfizer certas condições, ter conhecimento da teoria nos coloca em condições de interpretar corretamente as sentenças da língua para a qual temos a teoria. Isso é bastante distinto de afirmar que um falante possui o conhecimento da teoria. Retomaremos este tema quando examinarmos, no capítulo $\mathrm{V}$, justamente no que consiste do ponto de vista do teórico tal conhecimento da teoria da verdade.
} 
linguísticas. $\mathrm{O}$ que não exclui que se possa eventualmente emergir uma teoria capaz de explicar a composicionalidade semântica sem apelo a uma estrutura axiomatizada. Contudo, qualquer teórico que questione a condição de que a teoria seja recursiva tem que ser capaz de descrever a produtividade linguística de um falante sem usar um método recursivo. Desconheço qualquer um que tenha conseguido construir uma semântica sistemática não recursiva que consiga capturar a composicionalidade. É nesse sentido que se deve interpretar a sugestão de Davidson de "considerar anteriormente ao estudo empírico o que entendemos por saber uma língua, como devemos descrever a habilidade de uma pessoa que aprendeu a falar uma língua”. O foco da teoria é compreender o aspecto composicional do significado nas línguas naturais, e, por isso, para a teoria, saber uma língua compreende entender as sentenças da língua com base no domínio de como suas palavras podem ser usadas para produzir sistematicamente sentenças com diferentes significados. A proposta não consiste em reduzir o conhecimento semântico de um falante a meramente uma propriedade composicional. O que se estabelece de antemão, anteriormente à investigação empírica, é o que se considerará em uma teoria formal como conhecimento de uma língua: o domíno do seu aspecto composicional. E que uma maneira precisa e sistemática de se ter uma teoria que ilumine este aspecto é construí-la de forma recursiva. O que se requer é que uma teoria do significado esteja em conformidade com o critério da composicionalidade.

Mas como a condição da composicionalidade se conecta com o argumento em defesa de que uma teoria deve apresentar uma língua como passivel de ser adquirida? Essa articulação repousa sobre suposições suportadas empiricamente. $\mathrm{O}$ argumento da composicionalidade é conformado por uma série dessas suposições como premissas. São elas: (i) um falante de uma língua possui a capacidade de produzir e compreender novas sentenças não sinônimas; (ii) falantes de uma língua são criaturas finitas e, portanto, mortais; (iii) as línguas naturais podem ser aprendidas; (iv) tais criaturas finitas não possuem uma habilidade "mágica" de intuir os significados das sentenças sem dominar algum mecanismo de emprego de regras; (v) novos vocábulos e regras que um falante adquire parecem tomar um tempo finito para serem aprendidos. Dessas cinco proposições Davidson infere que é bastante plausível que os falantes de uma língua natural possuem um conjunto finito de "primitivos semânticos", i.e., um vocabulário finito. Portanto, deve ser possível fornecer uma explicação de como uma quantidade infinita de sentenças não sinônimas de uma língua podem ser compreendidas com base em um conjunto finito de itens básicos. $\mathrm{O}$ argumento também herda a sua força da suposição de que se um falante possuísse um vocabulário básico e regras de composição infinitas, não conseguiríamos explicar coerentemente como um ser finito possui uma capacidade potencialmente infinita; pois, se uma língua tivesse um vocabulário infinito, teríamos de ser capazes de compreender uma lista infinita de termos básicos (i.e., o significado de cada um desses termos) 
para que pudéssemos compreendê-la. Teríamos que levar um tempo infinito para adquirir essa língua. Tarefa impossível de antemão para uma criatura finita. A ideia que emerge é: uma língua natural é descrita como um conjunto finito de conhecimento que coloca seu falante na posição de atribuir significado a um número infinito de sentenças que constituem a língua. Posto dessa forma, se o argumento de Davidson estiver correto, uma língua é passível de ser aprendida se for conformada por um estoque finito de termos e um conjunto finito de regras composicionais. E, por essa razão, uma teoria semântica para uma língua L que fornece o significado das suas sentenças com base na sua estrutura, deve capturar o fato de que as infinitas sentenças de L são construídas a partir de um estoque finito de elementos e que seus significados são sistematimamente determinados pelo conteúdo semântico desses elementos.

Cabe aqui sublinhar, para evitar possíveis equívocos, que a hipótese de que o falante de uma língua possuiu um vocabulário finito não implica o comprometimento com a idéia de que o falante dominaria um conjunto de termos primitivos com uma cardinalidade que não se altera. Isso é facilmente refutável. Um falante está sempre em processo de aquisição de novos itens no seu vocabulário. O que a hipótese sugere é que em cada escala de tempo $t$ um falante $f$ terá domínio de um conjunto finito $x$ com uma cardinalidade $c$ de expressões básicas. E que, independentemente da variação de tempo que pode ocorrer entre falantes para a aprendizagem de novos termos (problema empírico que demanda investigação empírica), é bastante provável que todo novo termo e regra demandam um tempo para serem adquiridos. Outro ponto importante de destacar é que Davidson não intenta com seu projeto explicar como um falante adquire uma língua, no sentido de descrever etapas do desenvolvimento do aprendizado da primeira língua. O objetivo é de construir uma teoria que descreva as línguas naturais como linguagens passíveis de serem aprendidas. No que toca ao processo de aquisição, a condição unicamente é que a teoria não contradiga esse fato obvío acerca das línguas que falamos.

Para uma teoria na forma sugerida e caracterizada nas linhas gerais acima, quando se fala em significado de um termo ou de uma sentença deve-se entender o significado composicional. Sob esse enfoque, o significado de um termo primitivo é exaurido pela sua contribuição para o significado da sentença na qual ele ocorre, e, consequentemente, o significado da sentença exaurido pela contribuição das suas partes e regras de formação de sentenças. Davidson explicita essa ideia definindo um primitivo semântico tão somente pela sua contribuição composicional:

Chamemos uma expressão um primitivo semântico sob a condição de que as regras que dão o significado das sentenças nas quais ela não aparece não são suficientes para determinar o significado das sentenças nais quais ela parece (Davidson 1990 [1965]: 9). 
Essa definição é uma maneira de fixar, por assim dizer, o significado de um primitivo semântico em relação ao papel de todos os outros primitivos semânticos para o significado das sentenças em que eles ocorrem. Basicamente o que a definição diz é: todas as regras de composição e o significado de todas as expressões básicas de uma língua, com excessão de uma expressão básica $x$, não são suficientes para gerar os significos das sentenças em que $x$ ocorre como constituinte. Com respeito à habilidade linguística, a definição se traduz da seguinte forma: saber o significado de $x$ consiste em saber a sua contribuição para o significado de todas as sentenças em que $x$ aparece. O que implica que, se desconheço o significado de um item básico $x$ de uma língua L, ainda que conheça o significado de todas as expressões restantes de L, não conhecerei o significado de todas as sentenças formadas com $x$. Logo, haverá um conjunto infinito de sentenças de L que desconhecerei o significado. Os primitivos semânticos aqui não são senão as expressões que a teoria adota como conformando o vocabulário básico da linguagem sob investigação, i.e., as unidades básicas subsentenciais com as quais expressões complexas são formadas.

A teoria precisa ser desenhada para capturar como um falante compreende enunciados de sentenças em uma língua. Entender uma sentença de uma língua natural consiste em entender o seu significado em uma ocasião de uso, em uma realização concreta de uma sentença. Por isso, Davidson reconhece que uma teoria formal adequada incorporará na descrição das sentenças variáveis para falante, tempo e circunstância, pois uma sentença sempre é enunciada por um falante, em um período de tempo e em uma situação particular. Não é por acaso que a primeira menção de Davidson propondo que uma teoria inspirada pela definição de verdade de Tarski possa vir a fornecer uma "explicação construtiva" (que "uma definição de verdade na linha primeiramente exposta por Tarski [...] fornece um método efetivo para determinar o que toda sentença significa"), já é antecedida pela observação de que a teoria terá que ser "relativizada a tempo, lugar e circunstância”. Essa é uma adequação empírica essencial. Neste excerto já está exposto um dos desafios para o projeto de Davidson: elaborar uma teoria que incorpore na sua estrutura o fato de que sentenças significam relativas a um falante e tempo. Os casos mais evidentes dessa relativização são sentenças com expressões demonstrativas e dêiticas. Este fato exigirá uma adaptação do predicado ,verdadeiro“ quando empregado na geração do significado das setenças de uma língua. Como será elucidado no segundo capítulo da tese, quando apresentarei a definição de verdade de Tarski nos seus contornos gerais, para linguagens formalizadas o predicado de verdade será um predicado de sentenças, em que a variável em „x é verdadeira ${ }^{e e}$ será saturada por sentenças. Em contrapartida, o mesmo não poderá ser transferido para o tratamento de sentenças em línguas naturais, uma vez que o propósito é de descrever sentenças em contextos de uso. Em "Truth and Meaning” (1967), Davidson elaborará uma solução a esse problema, o que será determinante para a 
viabilidade empírica do seu projeto, i.e., se uma teoria como a proposta pode ser construída para uma língua natural. Examinaremos o problema de como tratar o predicado de verdade aplicado às línguas naturais no terceiro capítulo, que será dedicado às dificuldades impostas ao projeto de se perseguir uma semântica formal para as línguas naturais.

Atentemos, então, aqui ao quadro geral que emerge em TMLL. O projeto que Davidson começa a delinerar neste texto não consiste em perseguir uma explicação geral da natureza do significado, mas de propor uma teoria do significado para uma língua particular. Com isso em primeiro plano, extrai-se do texto um conjunto de condições que devem ser contempladas na conformação de uma teoria empírica do significado nas línguas naturais. São elas: (i) dado que as linguas naturais possuem a propriedade da composicionalidade, e que o objetivo é de fornecer uma teoria sobre o aspecto composicional do significado, essa teoria deve ser composicional de modo a refletir na sua estrutura a propriedade que quer descrever; (ii) uma teoria axiomática e com uma estrutura recursiva pode capturar a composionalidade das línguas naturais; (iii) línguas naturais são aprendíveis e, portanto, a teoria deve se conformar a esse fato e apresentar a língua que descreve como passível de aquisição; (iv) uma hipótese consistente acerca da possibilidade de que uma língua natural seja aprendível é assumir a finitude da classe de suas expressões básicas; por isso, a estratégia adequada consiste em fornecer uma teoria para uma língua particular que admite uma divisão entre uma classe finita de primitivos semânticos e as expressões complexas.

À luz dessas condições, na segunda parte de TMLL, Davidson exibe descrições vigentes de fragmentos da língua natural que, pare ele, seriam incompatíveis com os requerimentos da composicionalidade, ou de um vocabulário básico finito, ou ambos. Mas antes de passarmos às três soluções que Davidson ataca - as de Israel Scheffler (1954), W. V. Quine (1960) e Alonzo Church (1951) - é crucial, primeiro, sublinhar que elas emergem no contexto do debate acerca das sentenças de discurso indireto, em particular, e dos contextos opacos criados por verbos de atitude proposicional, em geral. Entretanto, para as objeções que Davidson levanta contra tais soluções em TMLL o que está em primeiro plano não são os desafios que os contextos opacos colocam para uma análise do significado das sentenças complementos de verbos de atitude proposicional, mas a identificação, na literatura, de soluções quanto à estrutura gramatical das sentenças que apresentam, na perspectiva do filósofo, dificuldades para uma compreensão adequada da estrutura composicional das línguas naturais. Mas, ao mesmo tempo, o fato de os três exemplos envolverem contextos intensionais não é uma mera coincidência. Tais contextos não somente colocam dilemas quanto à reificação do significado e à quantificação, mas também quanto ao fornecimento de uma teoria composicional compatível com a forma geral de uma teoria do significado perseguida por Davidson. Sem dúvida que, se o propósito nas subseções (1.1-1.3) fosse entrar diretamente no 
debate sobre contextos intensionais, para fazer justiça às explicações que ilustraremos neste capítulo, seria mandatório tratar com detalhe as (i) suas motivações, (ii) argumentos, (iii) a quem os autores intentam responder com elas e (iv) como analisam o conteúdo semântico dessa classe de sentenças. Dito isto, o que iremos abordar em (1.1-1.3) é, presumivelmente, uma aspecto das investigações de Schuffler, Quine e Church sobre essas sentenças. Esse aspecto é complementado por análises do seu conteúdo semântico. Mas o intuito aqui é apenas de ilustrar como que essas descrições, da maneira parcial em que são apresentadas em TMLL, não cumpririam as condições que Davidson espera que regulem uma análise. A questão nem é sequer se os autores visualizariam suas propostas como parte da construção de uma teoria da linguagem. Mas apenas que uma teoria composicional como concebida por Davidson é, para o filósofo, incompatível com as consequências que se pode entrever dessas propostas. No texto „On saying That ${ }^{\text {ee }}(1967)$, Davidon fornece uma análise própria do significado das sentenças de discurso indireto, que ficou conhecida como análise paratática e defende a sua consonância com as duas prescrições. Mas examinaremos esta solução e os problemas que ela suscita, assim como teremos a oportunidade de olhar para os outros aspectos das análises dos interlocutores de Davidson, no capítulo IV desta tese.

\subsection{Críticas a análises "concorrentes".}

Em ,An Inscriptional Approach to Indirect Discourse (1954), Israel Scheffler propõe, como primeira etapa de uma análise das sentenças de discurso indireto, tratar as sentenças complementos do verbo ,dizer que ${ }^{\text {ee }}$ como predicados de enunciados ${ }^{7}$. Uma sentença como

1. Galileo disse que a Terra gira ao redor do Sol.

é analisada como

2. Galileu disse um que-a-terra-gira-ao-redor-do-sol enunciado.

Os hiféns indicam que ,que-a-terra-gira-ao-redor-do-sol' deve ser tomado como um predicado de enunciados. Sendo fiél à terminologia de Scheffler, ,que-a-terra-gira-ao-redor-do-sol' assume a forma de um predicado unário (i.e., que pede um argumento) que se aplica ao que ele chama de “inscrições concretas” (concrete inscriptions). As realizações concretas de sentenças são as sentenças enunciadas em situações de uso. A sugestão de Scheffler é considerar todos os enuncidos 
possíveis (inscrições) em todas as línguas que contam como casos em que se diz que a Terra gira ao redor do Sol, e tomar (1) como apenas um desses casos. As inscrições podem também ser pensadas como tokens que instanciam types de sentenças, com os types caracterizados como funções predicativas de realizações concretas (escritas ou faladas) de sentenças. Um type, nesta abordagem, deve ser pensado como uma forma não relativa a uma língua específica. Nesse sentido, as inscrições, enunciados ou tokens são expressões realizadas, as quais pertencem a línguas específicas. Notem que aqui não há menção explícita ao significado da sentença ,a Terra gira ao redor do Sole em (1), ou seja, ao conteúdo informacional que veicula. Uma generalização deste método, entretando, a outras sentenças com verbos de atitude proposicional, como ,acreditar', 'saber', 'duvidar', etc., gera uma dificuldade. Dizer que Pedro acredita em algo que João não acredita não implica dizer que Pedro acredita em algum enunciado, pois podemos conceber um objeto de crença para o qual não há um enunciado correspondente. ${ }^{8}$

Nas palavras de Scheffler, então, estruturas ,que-p ' em sentenças da forma „, disse que-p' são construídas

[...] como predicados individuais [single predicates] de inscrições concretas e como tomando toda inscrição denotada por uma dada oração-que como uma reedição de toda outra denotada da mesma maneira [...] Uma sentença de discurso indireto tal como "J escreve que P" pode ser agora analisada como asseverando: "(Ex)(Ey) ( $\mathrm{x}=\mathrm{J}$. que-Py) . Inscreve $\mathrm{xy}$ ), onde "Que-P" é construído como um predicado de determinadas inscrições concretas (Sheffler, I. 1954: 84). ${ }^{9}$

A objeção de Davidson a esta análise está circunscrita a dois pontos, em parte independentes da dificuldade de aplicar o método a outros contextos de atitude proposicional. Ela é criticada por entrar em conflito, para Davidson, com o princípio de aprendizagem. O primeiro ponto é que nessa solução sentenças em contextos oblíquos são reescritas como predicados cujas estruturas internas são apresentadas como não estruturadas. Em outras palavras, Scheffler não apresenta uma descrição do papel composicional em (2) das expressões 'a', 'terra', 'gira', 'ao redor', 'do sol'. Os predicados de enunciados não são caracterizados pela análise como semanticamente complexos:

Scheffler propõe que analisemos „Tonkin disse que a neve é branca ${ }^{e e}$ como „Tonkin falou um que-a-neve-é-branca enunciado ${ }^{e}$. [...] A parte essencial da estória, do ponto de vista da presente preocupação, é tratada como um predicado unitário (de

\footnotetext{
${ }^{8}$ Além disso, ainda que o apelo a enunciados como instanciando um type não relativizado a uma linguagem tenha sido suficiente para descrever as sentenças de discurso indireto sem apelo direto à noção de proposição, a sua aplicabilidade a outros contextos opacos, por exemplo, „Galileo acredita que a Terra gira ao redor do Sol" terá evidentemente que estabelecer uma relação entre o conteúdo da sentença complemento e o conteúdo do que Galileo acredita.

${ }^{9} \mathrm{Na}$ citação em questão mantivemos a notação do autor. ,Е“é uma notação que representa a quantificação existencial, e „"a conjunção.
} 
enunciados ou inscrições). Scheffler chama ,que de um operador que se aplica para formar um termo geral composto. „Composto" não pode, neste uso, significar „logicamente complexo“' não ao menos até que mais teoria seja fornecida. Como no caso de citações, a sintaxe é clara o suficiente $[\ldots]^{10}$. Mas não há indício de como o significado desses predicados depende da sua estrutura. [...] Devemos ver cada novo predicado como um primitivo semântico. Fornecida a sua sintaxe, (coloque qualquer sentença depois de ,que entre hífens), é óbvio que existem infinitos predicados desse tipo; portanto, línguas sem mais estruturas do que as que Scheffler permite são, na minha abordagem, não aprendíveis. Mesmo a afirmação de que ,que é um operador formador de predicado deve ser reconhecida como um comentário puramente sintático que não tem eco em uma teoria do significado (Davidson 1990 [11965]: 12).

Davidon sustenta que Scheffler trata ,que-a-terra-gira-ao-redor-do-sol' como predicado da mesma forma que os predicados básicos. Logo, não fornece uma descrição semântica de como o significado de (1) depende do significado de suas partes. A solução de Scheffler não explica como as unidades que formam a sentença complemento do verbo „dizere afetam o significado de (1). Logo, o princípio da composicionalidade semântica não seria observado nesta solução.

A outra debilidade da estratégia, vinculada ao fracasso em exibir os predicados-de-inscrição como estruturas complexas, é que ela geraria um número potencialmente infinito de predicados da forma , $x$ é-um - ... - enunciado ${ }^{c e}$, onde ,...e pode ser ocupado por qualquer sentença. Não há limite para o número de sentenças que podem aparecer como complementos de sentenças de discurso indireto. Sendo o número de sentenças potencialmente infinito, teríamos também imediatamente infinitos predicados básicos, aspecto incompatível para Davidson com a natureza finita do conhecimento linguístico. Logo, uma linguagem com a estrutura representada pelo modelo de Scheffler, não seria possível de ser aprendida por um falante. Se correta, então, a diretriz geral de que composicicionalidade e finutude de vocabulário são imprescindíveis a uma teoria semântica, a implausibilidade empírica do esquema de Scheffler deriva de ele ser incompatível com ambos os requerimentos. A sua explicação local, restrita a sentenças de discurso indireto, além de acarretar uma lista infinita de termos básicos, não seria composicional.

Por fim, para concluir essas ponderações sobre a análise de Scheffler, quero sublinhar um ponto da crítica de Davidson que considero um pouco preciptada. A estratégia de conceber „que como uma expressão formadora de predicados unários a partir de sentenças - no sentido de ser caracterizada como um operador que transforma sentenças em predicados - é lida por Davidson

\footnotetext{
${ }^{10}$ Aqui a referência é a análises das citações que formulam uma regra sintática da forma: para que uma expressão primitiva ou complexa torne-se um nome que denota a própria expressão, coloque-a entre aspas. Esta descrição - quer se adote a ideia de que é a expressão no interior das aspas que passa a ser um nome ou a ideia de que o nome é composto da expressão mais as aspas - implica que há uma infinidade de nomes na língua, pois toda expressão da língua, seja ela uma palavra, uma concatenação de palavras ou sentenças, pode ser colocada entre aspas e tornar-se um nome. A regra sintática é simples e produtiva, mas a sua consequência para uma teoria semântica é inaceitável para Davidson.
} 
como uma regra meramente sintática. Nada é dito sobre o papel semântico dessa unidade línguística. Essa constatação é correta. Isso parece não excluir a priori, contudo, a possibilidade de que um semanticista forneça um modelo composicional satisfatório que interprete o operador „que de Scheffler, ou seja, que forneça uma semântica a ele. ${ }^{11}$

A objeção de Davidson em TMLL a Quine se dirige à forma que este propõe de descrever a composição estrutural das sentenças de crença (belief sentences) em Word and Object (1960). O foco da crítica não é a análise que Quine propõe de como interpretar o significado das sentenças sob o escopo de verbos de atitude proposicional. Este é um problema motivado pelo desafio posto em especial pela quantificação em contextos intensionais, substancialmente casos em que quantificadores fora do escopo dos verbos de atitude proposicional parecem ligar variáveis dentro dos contextos criados por esses verbos. Quine persegue uma análise dessas sentenças que as interpreta extensionalmente, i.e., sem tratar as variáveis como percorrendo entidades intensionais. Esse debate será tratado no capítulo IV, como já mencionado, onde investigaremos a proposta de Davidson de tratar contextos intesionais também de modo extensional. Aqui o propósito é somente exibir a crítica de Davidson em TMLL a como Quine exibe a composição das sentenças de crença a partir de suas unidades constitutivas. Vejamos então como essa crítica se aplica à proposta de Quine.

O recurso adotado em Word and Object consiste em conceber a sentença

3. Tom (disse que) acredita que Cícero denunciou Catilina.

como uma estrutura da forma $F a$, em que „Tom' substitui a e '(disse que) acredita que Cícero denunciou Catilina' substitui $F$. Quine trata toda a expressão 'acredita-que-p' como um predicado aplicado ao referente do sujeito da sentença. Diz Quine

\footnotetext{
11 Mas talvez seja algo nessa linha que Davidson sugere quando diz que, a menos que "mais teoria seja fornecida", os predicados gerados emergem como unidades não analisadas, pois a sua posição é de exigir que toda expressão básica de uma língua cumpra um papel semântico nas sentenças em que ocorre; uma análise semântica adequada não deve deixar nenhum item primitivo não analisado de uma sentença, pois isso acarreta, em virtude da própria composicionalidade, em não descrever o significado da sentença. A dificuldade em dar um tratamento semântico à expressão ,que ${ }^{e e}$ em sentenças de discurso indireto parece perdurar mesmo em teorias mais recentes adotadas pela maioria dos linguistas que trabalham com semantica formal. A teoria que aplica o cálculo lambda e o uso de tipos semânticos na caracterização da extensão das expressões linguísticas, teoria essa hegemônica no campo, adota posição, em espírito, semelhante à de Scheffler: ,que ec consiste num operador que toma uma sentença e a transforma em um predicado. Com a diferença que essa abordagem infla a sua ontologia com mundos possíveis, sendo o papel semântico do operador ,que fazer a sentença encaixada ,a terra gira ao redor do sol em (1) ser avaliada nos mundos em que o que Galileo diz é verdadeiro. Sentenças encaixadas passam a ser predicados de mundos: tomam mundos como argumentos e retornam valores de verdade. Evidentemente que o idioma de mundos possíveis é um flagrante distanciamento da estratégia de Scheffler, mas a descrição de ,que como um operador sobre sentenças e gerador de predicados permanece em essência a mesma. O mérito dessa análise, quer sejamos avessos ou não a uma ontologia de mundos possíveis, é que ela é feliz em incorporar a descrição sintática de ,que ${ }^{e e}$ a um modelo semântico.
} 
[...] não há necessidade de reconhecer, ,acredita ${ }^{e e}$ e verbos similares como termos relativos. Não há necessidade de aprovar seu uso predicativo como em,$w$ acredita $x^{\text {ee }}$

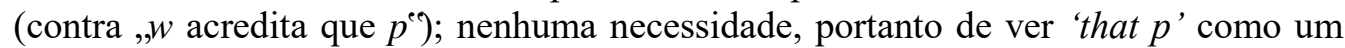
termo. Por isso uma alternativa final que acho tão atraente quanto qualquer uma é simplesmente dispensar os objetos de atitude proposicional. [...] Isso significa ver „Tom acredita (que) [Cicero denunciou Catiline] ]e não mais como da forma ' $F a b$ ' com $a=$ Tom e $b=$ [Cícero denunciou Catelile], mas sim como da forma , $F a^{\text {ee }}$, com Tom=a e o complexo ' $F$ '. O verbo, acredita aqui deixa de ser um termo e se torna parte de um operador ,acredita que um termo geral absoluto em que a sentença é contada como um constituinte imediato. (Quine, 1960: 215-216).

Na terminologia de Quine, um termo relativo é um predicado que estabelece uma relação entre objetos. Isto é, um predicado com dois ou mais argumentos. O verbo „crer é descrito como parte constituinte do operador ,crer-que $e^{e e}$ o qual, aplicado a uma sentença, geraria um predicado unário,

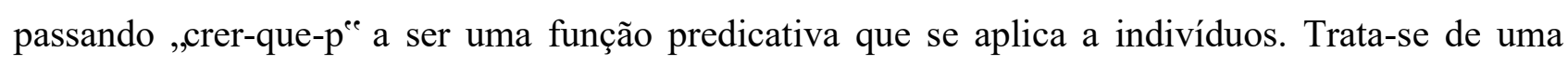
solução ainda aquém da análise de Scheffler no que diz respeito a tomar expressões complexas como sendo predicados. Enquanto na análise inscricional 'que-p' é tido como um todo não estruturado, e, portanto, para o qual não é apresentada uma análise semântica composicional das suas unidades constituintes, em Quine até mesmo o verbo de atitude proposicional é incorporado a uma forma de um predicado não estruturado. Isso dito fica fácil acessar as razões de Davidson rejeitar essa estratégia. Davidson duvida que esta solução seja compatível com o requerimento de que compreendemos sentenças de atitude proposicional com base em um número finito de primitivos semânticos e regras de composição.

Se há qualquer elemento além de uma sintaxe comum às sentenças de crença como uma classe, a explicação de Quine não diz que elemento é esse. E, claro, uma linguagem à qual nenhuma teoria a mais pode ser atribuída, é, pelas minhas contas, impossível de ser aprendida. (Davidson [1965] 1900: 13-14).

Trata-se de uma análise, portanto, que também não mostraria como as unidades constituintes de (3) contribuem composicionalmente para gerar (3). „Crer-que-p(x) é descrito como um todo, um pacote não submetido a uma composicionalidade interna, cuja função é de um predicado de um lugar. Sua contribuição é meramente de uma função sentencial satisfeita por objetos. E o efeito imediato de uma proposta deste tipo é que ela conduz a uma infinidade de primitivos semânticos, pois para cada sentença ' $p$ ', teremos um predicado ,x acredita que-pee.

Davidon identifica uma também incompatibilidade com o seu requerimento de um vocabulário básico finito na semântica de tipo neo-fregeana elaborada por Alonzo Church em "The Need of Abstract Entities in Semantic Analysis" (1951) e "A Formulation of the Logic of Sense and Denotation" (1951), que introduz uma hierarquia infinita de nomes e intensões. Church adota no seu 
método a soluação fregeana de tomar as palavras em sentenças complementos de verbos de atitude proposicional como se referindo ao sentido que expressam nos contextos extensionais. Uma sentença como

4. Pedro acredita que a Terra é o terceiro planeta do sistema solar.

é tratada como uma relação entre o referente de „Pedroe e a proposição (sentido/intensão) referida pela sentença ,a Terra é o terceiro planeta do sistema solar ${ }^{\bullet e}$. A motivação para tal análise é que em discurso indireto (i) o valor de verdade de (4) parece não depender do valor de verdade da sentença em itálico, e (ii) que em tais enunciados estamos preocupados não com as palavras empregadas por Pedro, mas com o sentido do que ele diz. A consequência imediata dessa estratégia é que em uma sentença que possui um verbo de atitude proposicional como complemento de outro verbo da mesma classe, como

5. Pedro acredita que Paulo acredita que a Terra é o terceiro planeta do sistema solar.

a sentença complemento em itálico em (5) passa a se referir não ao sentido referido por ela em (4), mas ao sentido que ela expressa em (4). Como a iteração de verbos de atitude proposicional, em princípio, pode continuar ocorrendo, ad infinitum, isso leva a uma hierarquia de sentidos. Notem que os sentidos expressos pelos termos e sentenças em contextos extensionais são, nos contextos opacos, referidos por essas "mesmas" expressões, as quais, por sua vez, passam a expressar novos sentidos. O que indica que, seguindo esse procedimento, termos e sentenças também serão necessários para expressar os sentidos dos termos e sentenças nos contextos opacos. Em (4), por exemplo, ,a Terra é o terceiro planeta do sistema solar ${ }^{\text {ee }}$ se refere ao seu sentido, mas também expressa um sentido, que, por sua vez, é referido em (5). A cada nova iteração de um verbo esse processo se repete e, assim, o número de sentidos que precisam ser postuladas. Quanto às expressões de uma linguagem intensional, então, duas soluções são possíveis: ou tratamos as expressões como infinitamente ambíguas ou introduzimos, por exemplo, índices subescritos nas expressões para indicar que, embora elas sejam homofônas e tenham a mesma grafia, elas são distintas. Na primeira solução, cada palavra em uma sentença resulta infinitamente umbígua, e, na segunda, o que se tem é um vocabulário básico infinito.

Em “A Formulation of the Logic of Sense and Denotation" Church opta pela segunda alternativa. De acordo com tal método, uma linguagem objeto conteria para cada expressão básica dela também um nome do sentido associado à expressão. Se tomarmos qualquer termo, por 
exemplo, a palavra „planetaee, de partida haverá duas entidades associadas a ela: sua extensão (uma classe) e seu sentido (uma propriedade), respectivamente. Mas se queremos falar sobre o sentido expresso por ,planeta ${ }^{e e}$, a linguagem deve ter um nome para o seu sentido, digamos, ,planeta ${ }^{{ }^{e e}}$. Logo, este último, no método em questão, terá por referência o sentido expresso por ,planeta ${ }^{e e}$, mas expressará um outro sentido. Com base nesta estratégia, e a sua aplicação aos contextos de verbos de atitude proposicional, como (5), somos levados a uma sequência infinita de termos básicos e entidades intensionais. Se um sistema semântico de tal tipo for aplicado à investigação das línguas naturais, ele de partida viola o requerimento davidsoniano baseado na tese de que um vocabulário infinito é incompatível com uma língua que pode ser aprendida. Em tal tratamento,

[...] são somente poucos passos para um vocabulário primitivo infinito. Depois das primeiras aparições de verbos como ,acreditar", introduzimos novas expressões para sentidos. [...] Um novo vocabulário é novamente necessário, na mesma linha, cada vez que iteramos ,acreditar'; e não há limite para o número de iterações possíveis (Davidson 1990 [1965]: 14)

Por conseguinte, se correta a objeção de Davidson, uma semântica de inspiração fregeana que assuma uma sequência infinita de sentidos associados a uma expressão ou uma infinitude de expressões primitivas apresenta uma dificuldade que Davidson entende essencial evitar em uma teoria do significado.

\section{Objeções a teorias semânticas que reificam significado.}

Em “Truth and Meaning”, artigo cuja primeira versão data de 1966, mas que somente foi publicado em $1967^{12}$, Davidson dá continuidade à elaboração do projeto de fornecer uma teoria semântica para as línguas naturais, principiado em “Theories of Meaning and Learnable Languages”. Nele Davidson retoma a tese central de TMLL e na sua primeira parte prossegue na crítica a outras tentativas de fornecer uma teoria do significado.

É admitido pela maioria dos filósofos da linguagem, e recentemente por alguns linguistas, que uma teoria satisfatória do significado deve fornecer uma explicação de como os significados das sentenças dependem do significado de suas palavras. A menos que tal explicação seja fornecida para uma língua particular, defende-se, não há como explicar o fato de que podemos aprender uma língua: [não há] como explicar o fato de que, dominando um vocabulário finito e um conjunto de regras estabelecidas de forma finita, estamos preparados a produzir e compreender qualquer infinidade em

\footnotetext{
${ }^{12}$ Uma versão preliminar de "Truth and Meaning" foi primeiramente lida em 1966, no evento Eastern Division Meeting of The American Philosophical Association. Contudo, o tema central do texto remonta a uma apresentação em 1962. A primeira publicação na sua versão final aparece na revista Synthèse, volume 17, 304-23, 1967. O texto foi reimpresso em Inquiries into Truth and Interpretation, volume I das obras de Davidson, cuja primeira edição data de 1984 . Todas as citações nesta tese dos textos que compõem Inquiries são extraídas da sua $3^{\circ}$ edição, de 1990.
} 
potencial de sentenças. Eu não disputo essas afirmações vagas, nas quais eu percebo mais do que um grão de verdade. Em vez disso, quero perguntar o que é para uma teoria dar uma explicação do tipo delineada (Davidson 1990 [1967]: 17).

Aqui Davidson retoma seu comprometimento com o projeto de perseguir uma teoria composicional do significado. Ele toma como suficientemente estabelecida a condição de composicionalidade, quando diz: “é admitido pela maioria dos filósofos da linguagem, e recentemente por alguns linguistas, que uma teoria satisfatória do significado deve fornecer uma explicação de como os significados das sentenças dependem do significado de suas palavras". Nesse sentido, em TM Davidson conecta seu projeto ao que ele considera a questão tradicional de tentar fornecer uma explicação que capture a natureza composicional do significado e menciona a tese em TMLL de que uma explicação composicional adequada lança luz sobre o fato de que aprendemos as línguas que falamos. Mas quando Davidson diz que não disputa "essas afirmações vagas", e que percebe nelas "mais do que um grão de verdade" ${ }^{13}$, ele está também enfatizando que a constatação da composicionalidade do significado não é meramente um truísmo. Com isso, Davidson quer chamar a atenção para o fato de que, embora a maioria dos filósofos e linguistas tomassem como verdadeiro o enunciado geral de que os significados das sentenças dependem do significado das suas partes, não aparecia em muitas de suas análises que eles atentassem suficientemente para o impacto que tratar a composicionalidade como o núcleo de uma investigação semântica das línguas naturais teria, digamos, sobre a estrutura de uma teoria do significado. Neste ponto, Davidson tem em mente análises tais como as rebatidas em TMLL, como examinamos na seção anterior. Tanto é verdade isso, que Davidson, nesta passagem, remete o leitor a uma nota indicando TMLL. Se o objetivo é iluminar a composicionalidade semântica, então, estabelece Davidson, uma questão não menos essencial consiste em reconhecer a composicionalidade também como prerrogativa fundamental a regular a forma de uma teoria do significado que se pretende empírica. Isto é, se o objeto da teoria é composicional, ou melhor, se a competência linguística envolve o domínio de um procedimento composicional, então a demanda que recai sobre a própria teoria é que ela deve também exibir (espelhar) essa propriedade semântica que investiga. Em outras palavras, somente uma teoria composicional pode fornecer interpretações das sentenças de uma língua especificando a contribuição semântica dos elementos subsentenciais e determinando princípios gerais de formação de unidades complexas por meio dos quais diferentes combinações dos elementos básicos produzem

\footnotetext{
${ }^{13}$ No original em Inglês da citação acima, Davidson usa a expressão "kernel of truth". Na passagem, o seu significado está em conformidade com o sentido comumente empregado em Inglês: de expressar a ideia de que há ao menos uma pequena verdade em algo, especialmente em alguma explicação ou relato dito por uma pessoa. A melhor expressão correspondente em Português ao significado mencionado em Inglês que encontramos é "grão de verdade". Esta tradução respeita bastante o contexto em que a expressão no original aparece e a sua finalidade na argumentação.
} 
diferentes significados. Por isso, a diretriz do projeto é de perseguir a pergunta: „o que é para uma teoria dar uma explicação da natureza composicional do significadoee. A perspectiva é de que, ao investigar e estabelecer as condições para um método geral de construir teorias adequadas, possa-se, mediante o fornecimento de uma teoria para uma língua particular, iluminar a natureza composicional do significado.

A mesma preocupação com a forma geral de uma teoria do significado é exibida de maneira ainda mais clara no parágrafo introdutório do artigo "Semantics for Natural Languages" (1970), que também pode ser incluído entre os textos programáticos do projeto $^{14}$ :

Uma teoria da semântica de uma língua natural objetiva fornecer o significado de toda expressão significativa, mas uma questão é que forma uma teoria do significado deve tomar para cumprir isso. ${ }^{15}$ Uma vez que parece não haver limite claro para o número de expressões significativas, uma teoria viável deve explicar o significado de cada expressão com base na exposição padronizada de um número finito de características. Mesmo que haja uma restrição prática sobre comprimento das sentenças que uma pessoa pode, com compreensão, emitir e receber, uma semântica satisfatória precisa explicar a contribuição de características repetíveis para o significado das sentenças nas quais elas ocorrem (Davidson 1990[1970]: 55).

"Truth and Meaning" consiste, justamente, na tentativa de esboçar essa teoria adequada do significado. Nele, pela primeira vez, aparece de forma suficientemente rigorosa nas suas linhas gerais o projeto davidsoniano de uma semântica formal para as línguas naturais. Em TM Davidson introduz e elabora, então, a proposta desafiadora, somente sugerida em TMLL, de que uma definição de verdade na linha de Tarski, tendo em conta modificações necessárias, cumpre o papel de veículo de uma teoria composicional do significado das línguas naturais.

TM pode ser lido como um texto dividido em duas partes. A primeira parte, que é crítica, ocupa a seis primeiras páginas do artigo. Ela consiste em levantar objeções contra a viabilidade de teorias semânticas que reificam significos, que tratam significados como entidades possíveis de serem referidas pelas sentenças. Junto com as objeções em TMLL discutidas na seção anterior deste capítulo, essa primeira parte de TM forma o que chamo de conteúdo crítico do projeto de Davidson. A segunda parte é o conteúdo propositivo e ocupa o restante do texto. Nela Davidson esboça pela primeira vez sua teoria do significado e também tenta enfrentar determinados problemas que (i) qualquer teoria do significado compreensiva deve tratar e (ii) problemas que emergem

\footnotetext{
14 "Semantics for Natural Languages" foi publicado pela primeira vez nos anais de um simpósio que ocorreu em Milão, Itália, em outubro de 1968. Os anais foram publicados somente em 1970, em Linguaggi enalla Società e nella Tecnica, Edisioni di Comunità, Milan.

${ }^{15}$ A parte em itálico é nossa.
} 
paticularmente do emprego da definição de verdade de Tarski na construção de uma teoria do significado.

$\mathrm{Na}$ presente seção, centrarei-me na objeção à reificação do significado na tentativa de fornecer uma teoria semântica, dando continuidade à exposição e interpretação das críticas de Davidson a propostas vigentes de explicação da natureza composicional do significado. A motivação para dedicar o primeiro capítulo a essas críticas, reiterando, resulta do fato de que se faz crucial, para uma interpretação acurada da semântica de Davidson, mostrar como elas conformam o cenário dentro do qual a proposta de Davidson é apresentada. Um exame acurado de TMLL e das seis primeiras páginas de "Truth and Meaning” é determinante para iluminar o que Davidson espera cumprir e a quais problemas responder com o uso de uma teoria da verdade no estilo de Tarski. ${ }^{16} \mathrm{~A}$ parte crítica do projeto e de conformação de algumas condições impostas a uma teoria do significado estabelecem, em grande medida, os termos da proposta e as discussões que se seguem a ela. Algumas interpretações questionáveis a respeito do projeto falham ao desconsiderar, ou não dar a devida importância, a esse conteúdo crítico.

São de duas ordens as objeções de Davidson a uma teoria que apela à reificação dos significados no tratamento composicional do significado para a linguagem natural. Chamarei elas de argumento do colapso lógico-semântico e argumento da utilidade. O argumento do colapso lógico-semântico consiste na tentativa de demonstrar que um semanticista que, por motivos teóricos, sustenta a hipótese de que sentenças são termos singulares complexos que se referem aos seus significados, é inevitavelmente forçado à conclusão falsa de que todas as sentenças com o mesmo valor de verdade são sinônimas, reduzindo o significa das sentenças a apenas dois: o referido pelas sentenças verdadeiras e o referido pelas sentenças falsas. Com o argumento da utilidade intenta-se mostrar que o comprometimento com significados como entidades não é nem necessário nem suficiente em uma teoria composicional do significado. Vamos a eles então.

\subsection{Argumento do colapso lógico-semântico.}

Nesta subseção, vou me deter ao argumento do colapso. Procurarei submetê-lo a um exame detalhado. Ele é mobilizado por Davidson com o objetivo de demonstrar que tomar sentenças como termos singulares que se referem aos seus significados implica o resultado intolerável de que todas as sentenças com o mesmo valor de verdade têm o mesmo significado. Optei por cunhá-lo de argumento do colapso lógico-semântico pelo fato dele conduzir a uma semântica insustentável, uma vez que circunscreve o significado de todas as sentenças de uma linguagem a apenas duas

\footnotetext{
${ }^{16}$ Para uma posição semelhante, ver Ludwig (2015).
} 
entidades. Espero rebater a alegação de Lepore \& Ludwig (2005) de que o argumento do colapso pressupõe o que pretende provar. Defenderei que ele não é circular, e configura-se sim como uma objeção robusta à reificação dos significados. Almejo, com isso, sustentar que o que pode ser apresentado pelo oponente de Davidson como suposição questionável, mas sobre a qual o argumento necessariamente se apoia, é consequência, na verdade, de premissas do argumento (estejam elas explícitas ou não), inclusive da tese que Davidson intenta refutar. Premissas as quais o semanticista sob ataque não pode rejeitar sem comprometer sua própria hipótese sobre o significado das expressões linguísticas. Por isso, as suposições apontadas por Lepore \& Ludwig (2005) não podem ser evitadas pelo proponente da tese de que sentenças são termos singulares complexos cujo significado é o seu referente. Daí a defesa de que o teórico que persegue uma semântica composicional adotando a tese que equipara os significados das palavras e das sentenças com seus referentes, não podendo eliminar esses enunciados implícitos no argumento do colapso lógicasemântico, necessariamente se verá comprometido com a conclusão indefensável de que todas as sentenças com o mesmo valor de verdade são sinônimas. Se há alguma vulnerabilidade no argumento, ela decorre da possíbilidade de não ter a generalidade que Davidson atribui a ele, e não a sua forma. Debrucemo-nos, então, sobre ele.

Como ponto de partida, tomemos um pequeno fragmento de linguagem conformado apenas por duas expressões: 'joão' e 'pai de x'. Suponha, assumindo que as duas expressões se referem ao seu significado, que o critério de uma teoria composicional satisfatória do significado seja que a teoria acarrete para as duas expressões do fragmento uma sentença da forma

\section{1. ' $x$ ' se refere a $y$}

onde , ‘x é substituída pela descrição estrutural de um termo $\operatorname{singular}^{17} \mathrm{e}$ „,y é substituída por um termo que se refere ao mesmo significado a que a expressão descrita por „' $x$ "e se refere. Desse modo, sendo 'João' um termo singular, seu significado é o seu referente, a saber, um indivíduo. Agora, adotemos a sugestão, que deriva de Frege, de que expressões como 'pai de $x$ ' são termos insaturados - obtidos a partir da substituição de uma expressão por uma variável - que se referem a funções que tomam objetos como argumentos. Sob esta análise, a função denotada por 'pai de $x$, retornará o pai de João como valor se João for tomado como argumento da função. Mas não nos contentemos com o escopo muito restrito da nossa teoria, com a qual não poderíamos formar sentenças, e ampliemos a sua aplicabilidade para incluir, por exemplo, a expressão predicativa ' $x$

\footnotetext{
${ }^{17}$ Uma descrição estrutural consiste em uma descrição de uma expressão como uma concatenação estruturada de elementos que pertencem a uma lista finita (concatenação de palavras ou letras).
} 
corre'. Estendendo trivialmente a noção de função para o termo 'x corre', tratemo-lo como uma expressão predicativa que se refere a uma função que também toma objetos como argumentos. Agora podemos gerar uma sentença com nossa teoria para uma linguagem com três termos. Notem que o critério de satisfação que adotamos exige que para todas as expressões da nossa linguagem simples, geremos uma sentença da forma (1) como teorema. Desse modo, com as ferramentas que temos em nossa teoria, formamos 'João corre' mediante a concatenação da expressão predicativa ' $x$ corre' com o termo singular „João derivamos a seguinte sentença:

2. „João corre’ se refere a joão corre.

Em (2) identificamos o significado de 'João corre' com o seu referente. 'João corre' se refere ao valor da função denotada por , $x$ corre', seja qual for tal valor, dado o referente de 'João' como argumento da função. Isto é, em (1) concebemos „João corre' como um termo singular que se refere ao seu significado ${ }^{18}$, da mesma maneira que identificamos o significado de „João' com seu referente. Esse processo composicional simples se revela um procedimento bastante efetivo, e que parece poder ser estendido, pelo menos em princípio, para toda sentença declarativa de uma linguagem objeto. Isto é, para toda sentença eu geraria um teorema da forma (1) que nos dá seu significado. A teoria realizaria ainda essa façanha "sem apelo a qualquer conceito semântico além

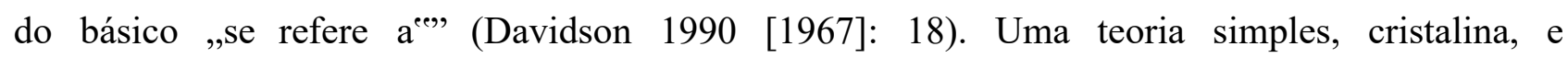
aparentemente bastante eficaz.

O ponto essencial do argumento do colapso lógico-semântico consiste, todavia, em mostrar que uma teoria composicional do significado que adota o esquema (1) é impratiável, pois conduz ao enunciado falso de que "todas as sentenças com o mesmo valor de verdade devem ser sinônimas um resultado intolerável” (Davidson [1967] 1990: 19). Em outros termos, o filósofo que adota a

\footnotetext{
18 Cabe aqui frisar que Frege não identifica, em contextos extensionais, os referentes das sentenças com seus significados. Para Frege os referentes das sentenças são seus valores de verdade: uma sentença verdadeira se refere ao verdadeiro e uma falsa ao falso. O projeto sob ataque é aquele que eventualmente se aproprie da solução fregeana para as expressões incompletas, empregando o método forjado por Frege para gerar composicionalmente a extensão das sentenças, como ferramenta para gerar o significado das sentenças, e não para chegar aos seus valores de verdade. Nesse projeto, a sentença formada, como no exemplo acima, da concatenação do termo singular „João "com ,,corre ${ }^{\text {ee }}$, que é em si também um termo singular, refere-se ao valor da função denotada por ,,corre ${ }^{e e}$ dado o referente de ,João ${ }^{c e}$ como argumento; mas esse valor não é um valor de verdade. Alguns o tomam como sendo um fato, outros uma situação, outros como sendo uma proposição. Contudo, como espero evidenciar no transcurso do texto, o tipo de referente tomado como o significado das sentenças não influi sobre a objeção de Davidson, que é direciona a toda teoria que assume que sentenças são nomes que se referem ao seu significado. A razão de Frege para rejeitar a identificação do referente de uma sentença com o seu significado é justamente a constatação do fato de que sentenças com o mesmo valor de verdade não precisam ter o mesmo significado. É motivado em parte por esta constatação que Frege propõe a clássica distinção entre sentido e referência.
} 
tese de que sentenças se referem ao seu significado não conseque evitar a consequência lógica que de todas as sentenças verdadeiras possuirão o mesmo significado. ${ }^{19}$

$\mathrm{O}$ argumento de Davidson se apoia fundamentalmente em duas premissas:

i. "Termos singulares logicamente equivalentes têm a mesma referência" (Davidson 1990 [1967]: 19);

ii. "Um termo singular não muda a sua referência se um termo singular nele contido é substituído por outro com a mesma referência” (idem 1990 [1967]: 19).

O princípio (i) estipula que dois termos singulares são logicamente equivalentes se, e somente se, correferem em todos os modelos. O princípio (ii) estabelece que se um termo singular constituinte de um termo singular complexo é substituído por outro com o mesmo referente, o termo singular complexo preservará o mesmo referente. Por exemplo, assumindo que descrições definidas são termos singulares, se „Tiradentes ${ }^{\text {ee }}$ e „Joaquim José da Silva Xavier ${ }^{\text {e }}$ correferem, então „A mãe de Tiradentes ${ }^{\text {ee }}$ tem o mesmo referente de „A mãe de Joaquim José da Silva Xavier ${ }^{\text {ee }}$

Davidson expõe seu argumento de maneira muito concisa, pulando etapas na sua demonstração, deixando que o raciocínio do leitor descubra as premissas encobertas. O filósofo o apresenta como se segue.

Tendo (i) e (ii) como hipóteses necessárias para o argumento, suponha que duas sentenças quaisquer „, $\mathrm{S}^{\text {ee }} \mathrm{e}, \mathrm{R}^{\mathrm{ee}}$ tenham o mesmo valor de verdade. Adicionado a isso, mantenha em mente que estamos identificando o significado de um termo singular com o seu referente. E que, sob essa lente, devido à (i) e ao fato de se tratar aqui "sentenças como um caso especial de termos singulares complexos" (Davidson 1990 [1967]: 19), sentenças também obedecem a (i) e (ii). Como resultado, as quatro sentenças abaixo, se logicamente equivalentes, terão a mesma referência:

iii. $\mathrm{R}$

\footnotetext{
${ }^{19} \mathrm{O}$ argumento é chamado frequentemente na literatura de "slingshot argument", em alusão à ideia de que um grande oponente (no caso, a reificação dos significados) é lançado por terra por uma pequena arma ("Slingshot" significa estilingue em Inglês), no caso um único argumento. Versões similares do argumento do colapso são apresentadas por Church e Gödel em textos que precedem cronologicamente "Truth and Meaning". Church e Davidson atribuem o argumento a Frege, sustentando que na obra do Filósofo já há o esboço informal do argumento. Entretanto, ao que tudo indica, é somente com Alonzo Church (1943) que ele aparece pela primeira vez formulado de forma precisa, numa estrutura de um argumento dedutivo, e numa versão muito semelhante ao formato do argumento exposto em "Truth and Meaning". A versão de 1943 está no artigo "Carnap“s Introduction to Semantics" e o argumento é retomado em "Introduction to Mathematical Logic" (1956), na seção do livro em que Church caracteriza proposições e funções proposicionais. O argumento de Gödel aparece no texto "Russell"s Mathematical Logic" (1944).
} 


$$
\begin{array}{ll}
\text { iv. } & \hat{x}(\mathrm{x}=\mathrm{x} \cdot \mathrm{R})=\hat{\mathrm{x}}(\mathrm{x}=\mathrm{x}) \\
\text { v. } & \hat{x}(\mathrm{x}=\mathrm{x} \cdot \mathrm{S})=\hat{\mathrm{x}}(\mathrm{x}=\mathrm{x}) \\
\text { vi. } & \mathrm{S}
\end{array}
$$

(iii) e (iv) são logicamente equivalentes, pois possuem o mesmo valor de verdade em todos os modelos: (iv) é verdadeira sempre que „,R é verdadeira e falsa se „, $\mathrm{R}^{\text {ee }}$ falsa. O mesmo se aplica a (v) e (vi). A verdade ou falsidade de (v) depende da verdade ou falsidade de (vi). E, se (iii) e (vi) têm o mesmo valor de verdade, então (iv) e (v) também possuem o mesmo valor de verdade. ${ }^{20}$

Logo, se o significado de um termo singular é seu referente e sentenças são termos singulares, dado que „, $\mathrm{R}^{\text {ce }} \mathrm{e}, \mathrm{S}^{\text {ce }}$ possuem o mesmo referente se tiverem o mesmo valor de verdade, tira-se a conclusão de que qualquer duas sentenças com o mesmo valor de verdade têm o mesmo significado. Mas, evidentemente, muitas sentenças com o mesmo valor de verdade não são sinônimas. Sinonímia sentencial garante mesmo valor de verdade, mas duas sentenças terem o mesmo valor de verdade não é condição suficiente para que elas sejam sinônimas. Por isso, a conclusão a que se chega via o argumento é nitidamente falsa.

Como deve ter aparecido ao leitor, Davidson apresenta seu argumento de forma comprimida, saltando alguns passos, de maneira que ficamos com a sensação, justificável, de que mais peças precisam ser destribuídas no tabuleiro para que possamos apreciar claramente o percurso do argumento. Seguindo Lepore \& Ludwig (2005), entendo que uma apresentação completa, atenta e esquemática do argumento é necessária antes de se avaliar a sua solidez como objeção. $\mathrm{O}$ argumento é reconstruído em Lepore \& Ludwig (2005) da seguinte forma:

a. “Termos singulares logicamente equivalentes têm a mesma referência” (Davidson 1990[1967]: 19);

b. "Um termo singular não muda a sua referência se um termo singular nele contido é substituído por outro com a mesma referência" (idem [1967]: 19).

c. Sentenças são termos singulares complexos e se referem ao seu significado;

d. Duas sentenças quaisquer , , $\mathrm{S}^{\text {ee }}, \mathrm{R}^{\text {ee }}$ possuem o mesmo valor de verdade;

e. $\quad$ „Reé logicamente equivalente a $\hat{x}(\mathrm{x}=\mathrm{x} . \mathrm{R})=\hat{x}(\mathrm{x}=\mathrm{x})^{e c}$;

f. Logo, , $, \mathrm{R}^{e e} \mathrm{e}, \hat{x}(\mathrm{x}=\mathrm{x} . \mathrm{R})=\hat{x}(\mathrm{x}=\mathrm{x})^{\text {ee }}$ possuem o mesmo referente $(a, c$ e $e)$;

\footnotetext{
${ }^{20}$ A forma concisa do argumento ilustrada em (iii-vi) é fiel à notação que Davidson emprega em "Truth and Meaning", p. 19: $\widehat{x}(\mathrm{Px})^{\text {ee }}$ para classes,,$"$ para conjunção e as letras maiúsculas , $\mathrm{R}^{\text {ee }} \mathrm{e}, \mathrm{S}^{\text {ee }}$ como variáveis sentenciais. Lepore \& Ludwig (2005) optam pela representação em termos de conjuntos quando tratam do argumento do colapso. Contudo, quando nos referirmos, nas págnas que se seguem, à exposição detalhada do argumento que esses comentadores apresentam, continuamos adotando a notação de Davidson, mas cientes de que a opção entre classes ou conjuntos não afeta o argumento.
} 
g. $, \hat{x}(\mathrm{x}=\mathrm{x} \cdot \mathrm{R})^{\mathrm{ee}} \mathrm{e}, \hat{x}(\mathrm{x}=\mathrm{x} \cdot \mathrm{S})^{\mathrm{ee}}$ são termos singulares com o mesmo referente $(d)$;

h. $, \hat{x}(\mathrm{x}=\mathrm{x} . \mathrm{R})=\hat{x}(\mathrm{x}=\mathrm{x})^{\text {ee }} \mathrm{e}, \hat{x}(\mathrm{x}=\mathrm{x} . \mathrm{S})=\hat{x}(\mathrm{x}=\mathrm{x})^{\text {ee }}$ têm o mesmo referente $(b$ e $g)$;

i. $\quad, \mathrm{S}^{\text {ee }} \mathrm{e}, \hat{x}(\mathrm{x}=\mathrm{x} . \mathrm{S})=\hat{x}(\mathrm{x}=\mathrm{x})^{\text {ee }}$ são logicamente equivalentes;

j. $\quad, \mathrm{S}^{\text {ce }} \mathrm{e}, \hat{x}(\mathrm{x}=\mathrm{x} . \mathrm{S})=\hat{x}(\mathrm{x}=\mathrm{x})^{\text {ee }}$ têm o mesmo referente $(a, c, i)$;

k. Logo, , , $\mathrm{R}^{\text {ee }} \mathrm{e}, \mathrm{S}^{\text {ee }}$ têm o mesmo referente. $(f, h, j)$;

1. Logo, , , $\mathrm{R}^{\text {ee }} \mathrm{e}, \mathrm{S}^{\text {ee }}$ têm o mesmo significado $(c, k)$.

(a) e (b) são as principais hipóteses (já foram mencionadas como (i) e (ii)) e operam na passagem de (d) para (h), uma vez que , $\hat{x}(\mathrm{x}=\mathrm{x})^{\mathrm{ee}}, \hat{,}, \hat{x}(\mathrm{x}=\mathrm{x} . \mathrm{R})^{\mathrm{ee}} \mathrm{e}, \hat{x}(\mathrm{x}=\mathrm{x} . \mathrm{S})^{\mathrm{ee}}$ são tomadas como expressões referenciais. Como pode ser notado, (b) é uma forma de anunciar o princípio da substitutividade de termos coextensivos no interior de um termo singular complexo: o termo complexo não muda a sua referencia se um termo que ele contêm é substituído por um outro termo com a mesma referência. (c) é a hipótese sob ataque. Em (e) é asseverada a equivalência lógica entre a sentença „R $\mathrm{R}^{\mathrm{ee}} \mathrm{e}$ uma sentença de identidade cuja verdade ou falsidade depende completamente da verdade ou falsidade de „R $\mathrm{R}^{e \bullet}$.Ou seja, a verdade das sentenças

$a^{e e}$. Termos singulares logicamente equivalentes têm o mesmo referente.

$c^{c e}$. Sentenças são termos singulares e se referem aos seus significados. $\mathrm{e}^{e e},{ }_{\text {, }} \mathrm{R}^{e e} \mathrm{é}$ logicamente equivalente a, $\hat{x}(\mathrm{x}=\mathrm{x} . \mathrm{R})=\hat{x}(\mathrm{x}=\mathrm{x})^{e e}$.

implica a verdade de

$\mathrm{f}^{\mathrm{ee}} ., \mathrm{R}^{\mathrm{ee}} \mathrm{e}, \hat{x}(\mathrm{x}=\mathrm{x} . \mathrm{R})=\hat{x}(\mathrm{x}=\mathrm{x})^{\text {ee }}$ possuem o mesmo referente.

Do mesmo modo, (a), (c) e (i) implicam (j). E, dado que expressões como , $\hat{x}(\mathrm{x}=\mathrm{x}, \mathrm{R})^{\mathrm{ee}} \mathrm{e}, \hat{x}(\mathrm{x}=\mathrm{x}$. $\mathrm{S})^{\text {ee }}$ são tratadas como termos singulares que correferem - $(\mathrm{g})$, uma vez que „, $\mathrm{R}^{\mathrm{e}} \mathrm{e}$, ,S $\mathrm{S}^{\mathrm{e}}$ são tidas como possuindo o mesmo valor de verdade - (d), se , ,R $\mathrm{R}^{\text {ee }}$, ,S $\mathrm{S}^{\text {ee }}$ ão ambas falsas, $, \hat{x}(\mathrm{x}=\mathrm{x} . \mathrm{R})^{\text {ee }} \mathrm{e}, \hat{x}(\mathrm{x}=\mathrm{x}$. $\mathrm{S})^{\text {ee }}$ se referem à classe vazia, e à classe universal se „, $\mathrm{R}^{\mathrm{e}} \mathrm{e}, \mathrm{S}^{\mathrm{e}}$ são verdadeiras. Em outras palavras, $, \hat{x}(\mathrm{x}=\mathrm{x} . \mathrm{R})^{\mathrm{ee}} \mathrm{e}, \hat{x}(\mathrm{x}=\mathrm{x} . \mathrm{S})^{\text {ee }}$ são coextensivas porque ou ambas se referem à classe vazia ou ambas se referem à classe universal. Por isso, dado (b), i.e., um termo singular não muda seu referente se um termo singular nele contido é substituído por um outro com a mesma referência,,$\widehat{x}(\mathrm{x}=\mathrm{x} . \mathrm{R})^{e e} \mathrm{e}$ ,$\hat{x}(\mathrm{x}=\mathrm{x} . \mathrm{S})^{\text {ee }}$ podem ser substituídas uma pela outra em um termo singular complexo que as contêm, preservando a extensão deste termo complexo. Portanto, a verdade de (b) e (g) implica a verdade de 


$$
\mathrm{h}^{\text {ee }}, \hat{x}(\mathrm{x}=\mathrm{x} . \mathrm{R})=\hat{x}(\mathrm{x}=\mathrm{x})^{\text {ee }} \mathrm{e}, \hat{x}(\mathrm{x}=\mathrm{x} . \mathrm{S})=\hat{x}(\mathrm{x}=\mathrm{x})^{\text {ee }} \text { têm o mesmo referente. }
$$

Assim, percorrendo uma cadeia de identidades de referentes, que começa em (f), passa por (h) e (j) e chega a $(\mathrm{k})$, i.e., que , $\mathrm{R}^{\mathrm{ce}} \mathrm{e}, \mathrm{NS}^{\mathrm{e}}$ têm o mesmo referente, conclui-se, tendo por hipótese que sentenças são termos singulares que se referem ao seu significado - (c), que „, $\mathrm{R}^{\text {ee }}$, ,S têm o mesmo significado.

Observem que o princípio (a) do argumento não diz que todos os termos com a mesma referência são logicamente equivalentes. Apenas estipula que termos singulares logicamente equivalentes têm de ser coextensivos. Do que se segue que (g) apenas conclui, com base em (d) $, \mathrm{R}^{\text {ee }} \mathrm{e}, \mathrm{S}^{\text {ee }}$ têm o mesmo valor de verdade - que , $\hat{x}(\mathrm{x}=\mathrm{x} . \mathrm{R})^{\text {ee }} \mathrm{e}, \hat{x}(\mathrm{x}=\mathrm{x} . \mathrm{S})^{\text {ee }}$ são termos singulares com o mesmo referente, não que eles necessariamente correferem. O resultado do argumento nos diz que todas as sentenças com o mesmo valor de verdade em um dado modelo qualquer terão o mesmo significado. Mas como só há dois valores de verdade, sempre haverá só dois referentes como significados. Já as sentenças que são logicamente equivalentes serão sinônimas em todos os modelos.

Se o argumento do colapso lógico-semântico é sólido, o que acredito que o seja, a suposição de que sentenças são nomes que se referem ao seu significado se torna indefensável porque compromete o teórico proponente desta posição com a conclusão de que todas as sentenças verdadeiras são sinônimas. Mais exatamente, mesmo valor de verdade implicaria mesmo significado.

\subsubsection{Objeção à objeção de Lepore e Ludwig ao argumento.}

Lepore \& Ludwig (2005), embora compartilhem do ceticismo davidsoniano quanto à utilidade empírica do apelo a significados como entidades - a segunda objeção de Davidson à reificação, e que ainda será tratada neste capítulo - alegam que o argumento lógico-semântico de Davidson apresenta um ponto de vulnerabilidade. Segundo os comentadores, ele pressupõe em vez de provar que mesmo valor de verdade implicaria, para o proponente de que sentenças se referem aos seus significados, mesmo referente. De forma mais geral, eles entendem que não há razão para supor que o conceito de equivalência lógica entre sentenças implicaria o de equivalência lógica entre termos singulares. Eles argumentam que há uma suposição escondida (pressuposta) que opera na passagem de (e) para (f), e da qual o argumento depende para "não se equivocar a respeito de „equivalência

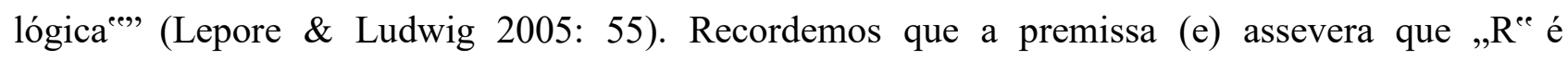
logicamente equivalente à , $\hat{x}(\mathrm{x}=\mathrm{x} . \mathrm{R})=\hat{x}(\mathrm{x}=\mathrm{x})^{\mathrm{ee}}$, e (f) conclui que ambos possuem o mesmo 
referente. Entre (e) e (f) se interporia a seguinte premissa, que os autores chamam de „Suposição Escondida" (,Hidden Assumption'): "se duas sentenças são logicamente equivalentes, no sentido de que ambas são verdadeiras em todos os modelos, então se elas são termos singulares, elas são termos singulares logicamente equivalentes. (Lepore \& Ludwig 2005: 54). Prosseguem os comentadores,

\begin{abstract}
A Suposição Escondida seria justificável se houvesse razão em manter que o que é preservado em todos os modelos em pares de sentenças logicamente equivalentes no primeiro sentido de ,equivalência lógica é o mesmo do que é preservado em todos os modelos no segundo sentido de ,equivalência lógicae . Isto é, precisamos de uma razão para sustentar que mesmo valor-de-verdade implica o mesmo referente. Mas [...] para sustentar esse argumento devemos já ter estabelecido o que nos propomos a mostrar. $\mathrm{O}$ que precisamos é de um argumento para a suposição de que sentenças logicamente equivalentes co-referem - se sentenças são termos singulares - que parte de suposições que o proponente da visão de que sentenças se referem aos seus significados não poderiam rejeitar como caindo em petição de princípio [question begging](Lepore \& Ludwig 2005: 54).
\end{abstract}

Equivalência lógica é usualmente atribuída a sentenças, no sentido de duas sentenças serem logicamente equivalentes se, e somente se, elas possuírem o mesmo valor de verdade em todos os modelos. Mas uma das hipóteses necessárias para o argumento do colapso é a estipulação de equivalência lógica para termos singulares: termos singulares são logicamente equivalentes se, e somente se, possuem a mesma referência ${ }^{21}$. Em vista dessa postura, os autores chamam a atenção para esses dois significados distintos de equivalência lógica operando no argumento, e que justamente a função da hipótese escondida é explicitar, na sua estrutura condicional, esses dois sentidos, e asseverar que equivalência de valor de verdade acarreta equivalência de referente, se sentenças forem termos singulares. Mas qual é o problema entrevisto nisso pelos comentadores? O equívoco, crêem os autores, é que não podemos tratar essa hipótese escondida “como verdadeira por definição, uma vez que ser verdadeiro em todos os modelos e correferir em todos os modelos não são equivalentes” (ibidem 2005: 54). O significado de „logicamente equivalente no antecedente é o de equivalência sentencial e o no consequente é de equivalência entre termos singulares, e não haveria razão para inferir o segundo sentido à partir do primeiro. Faltaria, portanto, um argumento na demonstração para se sustentar que equivalência de valor de verdade implica mesmo referente. E, por isso, “está aberto ao oponente de Davidson negar a Hipótese Escondida” (ibidem 2005: 54). O outro ponto, e o mais relevante para os comentadores, é que para sustentar uma relação entre os dois "sentidos" de equivalência devemos já ter pressuposto o que queremos na verdade demonstrar.

\footnotetext{
${ }^{21}$ Para uma generalização sistemática da noção de equivalência lógica de maneira que não apenas sentenças, mas também nomes, expressões predicativas, conectivos e quantificadores possam ser logicamente equivalentes a outros nomes, predicado, conectivos, etc., ver Naming and Necessity (1947), de Rudofl Carnap.
} 
A prova, portanto, argumentaria em círculos. Ou seja, tenta-se provar uma conclusão mobilizando a própria conclusão como suporte.

Não me parece, entretanto, que o argumento supõe o que pretende demonstrar. O que $o$ argumento do colapso revela, entendo, é que a articulação entre os dois sentidos de equivalência lógica - vínculo indesejado - é estabelecido assim que tomamos sentenças como nomes cujos significados são seus referentes. Isso porque as sentenças passam a herdar o sentido de equivalência lógica próprio dos termos singulares, mas continuam tendo valor de verdade. Em outras palavras, o argumento prova que equivalência lógica, no sentido de mesmo valor de verdade em todos os modelos, acarreta equivalência lógica no sentido de correferência em todos os modelos, se trato sentenças como nomes. Essa relação indesejada é implicada pela hipótese de que a categoria linguística ,sentença ${ }^{e e}$ é semanticamente identificada com a categoria „termo singular ${ }^{\text {ee }}$ Sempre que falar de equivalência lógica entre sentenças, tendo-as como termos singulares, e identificando o significado de um termo singular completamente com o seu referente, serei forçado inevitavelmente a me comprometer com a conclusão de que sentenças logicamente equivalentes terão a mesma referência. A passagem necessária de mesmo valor de verdade para mesmo significado é consequência da definição de sentenças em termos de nomes próprios, e da noção de que o significado de um nome é a entidade a que ele se refere. Isto é, essa implicação se desdobra da definição, já que ela identifica sentença com nome próprio e preserva o fato de sentenças serem portadoras de verdade.

Além disso, não é que sem a suposição escondida o argumento se equivoca quanto aos significados de „logicamente equivalente ${ }^{e e}$, como pensam Lepore \& Ludwig (2005). É a interação entre as premissas (a), (b), (c) e (d) que provoca esse equívoco (lembrando que (c) é a tese a ser refutada), independentemente se a Suposição Escondida, ou qualquer outra que por ventura seja adicionada, explicite os dois sentidos de equivalência. Esse "colapso" dos dois sentidos é engendrado pela tese. $\mathrm{O}$ que a premissa escondida parece estar fazendo é meramente evidenciando essa vinculação dos dois sentidos que, mesmo sem ela, será estabelecida no percurso do argumento. É como se ela anunciasse, ou melhor, reiterasse o que será inevitável.

Mas se é insustentável manter que um sentido de equivalência implica o outro, e, por outro lado, não podemos rejeitar esse vínculo sem abandonar a tese de que sentenças são termos singulares que se referem ao seu significado, então resta uma única saída para esse impasse: descartar a tese. Daí a conclusão, pouco provável de ser refutada, de que pode haver somente uma possibilidade de „, $\mathrm{R}^{\text {ce }} \mathrm{e}, \mathrm{S}^{\text {ee }}$ terem realmente a mesma referência, a saber, designarem o mesmo valor de verdade. Mas - como Frege já corretamente frisou - não se pode adotar o valor de verdade de uma sentença como seu significado (sentido), já que a implicação disso é que todas as sentenças 
verdadeiras seriam sinônimas, designando $O$ Verdadeiro, e todas as sentenças falsas teriam o mesmo significado, designando $O$ Falso.

As considerações apresentadas na seção IV indicam, a meu ver, que o argumento do colapso lógico-semântico sobrevive à investida de Lepore \& Ludwig (2005). Nesse sentido, tal como formulado por Davidson, ele preserva a sua força e centralidade como demonstração de que teorias composicionais que identificam sentenças com nomes e referência com significado não funcionam porque somos obrigados, com isso, a sustentar uma relação de implicação, no caso da equiparação de sentenças com termos singulares, entre mesmo valor-de-verdade e sinonímia. Conclusão essa patentemente falsa. A vinculação entre os dois sentidos de equivalência não é uma estipulação arbitrária do argumento, mas consequência inegável de uma concepção falsa de significado: a que identifica significado com referência. $\mathrm{O}$ equivoco a respeito de equivalência lógica, no sentido de equivalência de valor-de-verdade ser suficiente para acarretar equivalência de significado, é um desdobramento incontornável da tese sob ataque. Seu proponente não tem alternativa. Somente é possível rejeitar que sentenças com o mesmo valor-de-verdade são sinônimas se ele abandonar que sentenças são nomes que se referem aos seus significados.

\subsection{Argumento da utilidade.}

Davidson não restringe a fonte do seu forte ceticismo a respeito do apelo a significado como entidade unicamente ao argumento do colapso lógico-semântico. Em "Truth and Meaning” há uma série de observações que dão corpo a um argumento contra a utilidade de se quantificar sobre significado na tentativa de explicar como compreendemos e dominamos a língua que falamos. Trata-se de uma argumentação que procura mostrar que um ontologia de significados não é nem necessária nem suficiente em uma teoria do significado. A conclusão crucial a que essa objeção conduz é que mesmo em uma teoria que quantifica sobre significados, o entendimento do significado de uma expressão da linguagem sob escrutínio, quer essa expressão seja básica ou complexa, depende da combinação da expressão com um outro termo cujo significado já sabemos anteriormente e que é usado para traduzir/interpretar a expressão. Ou seja, o entendimento das expressões se dá mediante a familiaridade com o significado dos termos que traduzem as expressões. O apelo explícito a significado como entidade não contribui em nada para nos fornecer a compreensão de qualquer expressão de uma língua: o trabalho é feito completamente pelos termos que tomamos como traduzindo as expressões cujos significados queremos iluminar. Logo, a adoção de significados como variáveis de quantificação seria redundante e prescindível, já que o mesmo pode ser feito sem esse comprometimento ontológico. 
Nesta subseção, então, examinarei as passagens de "Truth and Meaning” em que Davidson argumenta contra a utilidade teórica de uma ontologia de significados, mas também abordaremos a continuação dessa objeção nos trabalhos de Ernest Lepore e Kirk Ludwig. Viso mostrar que esses autores, além de interpretarem esta tese como a mais robusta contra a reificação, postura de que compartilho, refinam o argumento e fortalecem seu apelo.

\subsubsection{Ataque à utilidade da reificação em "Truth and Meaning".}

Davidson começa a parte crítica de "Truth and Meaning" observando que a mera atribuição de entidades às palavras individuais de uma língua não nos ajuda quando o problema é explicar como entendemos expressões complexas com base na compreensão das expressões simples. O caminho mais fácil pode parecer - no caso de uma sentença do tipo „Teeteto voa ${ }^{e e}$ - a opção de assinalar a entidade Teeteto ao nome próprio „Teeteto“e e a propriedade de voar à expressão predicativa „,voä. Em seguida estipular que a sentença „Teeteto voa ${ }^{\text {ee }}$ resulta meramente da operação de concatenação, e que essa operação se refere à relação de instanciação, i.e., a relação de uma entidade instanciar uma propriedade. Com isso, no entanto, o que fazemos é somente adicionar mais uma entidade ao lado de Teeteto e a propriedade de voar, que, por sua vez, demanda uma outra relação para concatenar essas três entidades. Logo, é fácil de ver, recorda Davidson, que isso conduz a um regresso infinito. ${ }^{22}$

Precisamos então mais do que somente o assinalamento de entidades, pois necessitamos de alguma regra que nos diz como ir dos termos simples aos complexos. Para ilustrar uma regra com esta função, Davidson introduz uma teoria da referência para um pequeno fragmento de uma língua, com o propósito de mostrar que até mesmo em uma teoria simples como a sugerida parece não ser necessário vincular uma entidade a toda expressão. Diz Davidson:

\footnotetext{
${ }^{22}$ Aqui Davidson remete ao problema da natureza da predicação, que remonta ao menos até Platão. Este problema pode ser posto de distintos ângulos. Com respeito à forma dos juízos, pode-se perguntar: como particulares e propriedades são relacionados na constituição da estrutura dos juízos? Ele pode ser levantado também como uma questão metafísica: Como os particulares se relacionam com os universais? Mas do ponto de vista semântico, que é o que interessa a Davidson, pode-se recolocar a pergunta do seguinte modo: como são nomes ou outros termos singulares (referenciais) relacionados com predicados de maneira a estruturar uma predicação? O núcleo do problema da predicação constitui justamente na dificuldade de se evitar o regresso infinito. Uma sentença não é meramente sequência de palavras, e a semântica de uma sentença como "Teeteto voa" não é exaurida se referindo a duas entidades: teeteto e a propriedade de voar. $\mathrm{O}$ que o regresso ao infinito evidencia é que não basta apenas insistir que o papel do verbo (predicado) é de expressar uma relação de instanciação, pois essa estratégia termina por acrescentar mais uma entidade (que pode ser referida por uma cópula como na sentença "Teeteto é inteligente"), de forma que ficamos com três entidades: uma pessoa, uma propriedade e uma relação. Com isso somos forçados a dar mais um passo e introduzir mais uma entidade para assegurar a unidade das três mencionadas e assim ad infinitum. A natureza da predicação é um daqueles problemas que tem intrigado filósofos por dois milênios, e permaneceu não resolvido ao menos até Frege, quando é proposto o tratamento revolucionário da estrutura sujeito-predicado em termos de argumento-função, que abriu a possibilidade inclusive de dar um tratamento preciso a predicações com estruturas quantificacionais. Para uma discussão do problema da predicação por Platão, ver o viálogo "Sofista" (261D-264B). Para uma análise críticohistórica deste tema, ver o livro de Davidson "Truth and Predication" (2005), em especial os capítulos 4 e 5.
} 
O ponto emergirá se pensarmos por um momento sobre os termos singulares complexos, aos quais a teoria de Frege se aplica junto com as sentenças. Considere a expressão „o pai de Annette "e como o significado do todo depende do significado das partes? A resposta parece ser que o significado de „o pai de é tal que quando essa expressão é prefixada a um termo singular o resultado se refere ao pai da pessoa referida pelo termo singular. Qual parte é desempenhada, nessa explicação, pela entidade insaturada ou incompleta a qual „o pai de se refere? Tudo o que podemos pensar em dizer é que essa entidade ,fornecee ou ,dáee o pai de x como valor quando o argumento é $\mathrm{x}$, ou talvez que essa entidade mapeia pessoas em seus pais. Pode não ser claro, se nos atermos a expressões individuais, se a entidade que se diz que „o pai de denota desempenha qualquer função explanatória genuína; então em vez disso pense sobre a classe infinita de expressões formadas escrevendo „o pai de" uma ou mais vezes na frente de „Annette ${ }^{\text {ee }}$ É fácil fornecer uma teoria que diz, para um desses termos singulares, a que ele se refere: se o termo é „Annetee", ele se refere a Annette, enquanto se o termo é complexo, consistindo em „o pai de" prefixado a um termo singular $t$, então ele se refere ao pai da pessoa a quem $t$ se refere. É óbvio que nenhuma entidade correspondendo a „o pai de é ou precisa ser mencionada ao estabelecer a teoria (Davidson 1990 [1967]: 18).

Em primeiro lugar, a passagem acima demanda algumas clarificações, para evitar mal entendidos, antes de indentificarmos o que Davidson quer mostrar com ela. Nela Davidson se refere explicitamente à solução revolucionária de Frege de tratar expressões predicativas como se referindo a entidades insaturadas (incompletas), em que há um espaço na posição de argumento a ser preenchido pelo referente (entidade saturada) de um nome próprio. Com essa estratégia e sua generalização a outros termos da linguagem, como os quantificadores, que passam a ser tratados como funções insaturadas que tomam funções como argumento, Frege elaborou uma teoria que muitos veêm como evitando o regresso infinito. Mas na passagem citada deve ficar explícito para o leitor que Davidson se distancia de Frege ao apresentar as expressões insaturadas como se referindo ao seu significado, para, em seguida, questionar a utilidade dessa estratégia. Em Frege as entidades insaturadas denotadas pelas expressões predicativas não são seu significado; o seu significado é o sentido que elas expressam. Outro afastamente com respeito à teoria de Frege é que Davidson circunscrebe o significado de um nome, na argumentação acima, somente ao seu referente. Dito isso examinemos a argumentação de Davidson neste fragmento.

Davidon seleciona como linguagem sob exame um fragmento do Inglês - formado de duas expressões: o termo singular simples „Annette ${ }^{\text {ee }}$ e o termo insaturado ,the father of ${ }^{\text {ee }}$. Em seguida nos pede para tentar responder à pergunta: qual seria o papel desempenhado por uma suposta entidade referida pela expressão ,the father of ${ }^{\text {ee }}$ para a constituição do significado do termo singular complexo ,the father of Annette ? O papel parece ser evidente: referir-se ao pai da pessoa a que o nome „Annette ${ }^{e e}$ se refere. E até já temos à disposição um método que dá conta de iluminar esse papel: a sugestão fregeana de tratar „the father como uma função insaturada. Sob tal análise, „the 
father of ee retorna como valor o pai do referente do nome ao qual aquela expressão é prefixada. Assim caracterizada a expressão ,the father of $x^{\text {ee }}$, pode-se formular a seguinte regra composicional:

$\left(r^{\prime \prime}\right)$. O referente da prefixação de ,the father"e a um termo referencial t é o valor da função referida por ,the father of ${ }^{\text {ec }}$ dado o referente $t$ como seu argumento. ${ }^{23}$

Dado qualquer termo referencial $\mathrm{t}$ a regra acima nos retorna o pai de $\mathrm{t}$, e é isso que queríamos com nossa pequena teoria referencial: uma regra de geração composicional de termos referencias complexos. Mas Davidson observa que a mesma regra pode ser recolocada excluindo referência a

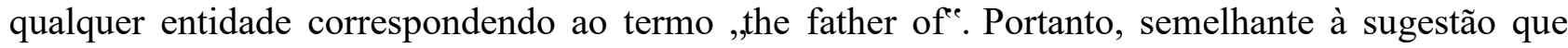
aparece na citação acima, pode-se reformular a regra da seguinte maneira:

(ree). O referente da prefixação de „the father of a um termo referencial t é o pai (do referente) de t.

Três pontos devem ser explicitados aqui. O primeiro é que $\left(\mathrm{r}^{\mathrm{ec}}\right)$, embora a sua aplicação nos retorne o referente correto, não nos capacita a depreender o significado de ,the father of ${ }^{e}$. Posso compreender $\left(\mathrm{r}^{\mathrm{ee}}\right)$, aplicá-la, e ainda assim desconhecer o significado de „the father of ${ }^{\mathrm{ee}}$. A menção de que „the father of ${ }^{e}$ se refere a uma função não foi suficiente para capturamos seu significado. O segundo ponto é que a regra $\left(\mathrm{r}^{\text {eeeg }}\right)$ nos retorna também o referente correto da expressão da concatenação de ,the father"e com um termo t, e o faz isso sem apelo a uma entidade denotada por „the father of ${ }^{\text {ee }}$. O terceiro ponto é que a impressão de que $\left(\mathrm{r}^{\text {eeee }}\right)$ nos parece dar o significado de „the fatehr of está correta. Isso porque, ao estabelecer ( ${ }^{\text {eee }}$ ), tacitamente assumimos que a expressão usada em português, „o pai de ${ }^{e e}$, traduz a expressão mencionada „the father of ${ }^{\text {ec }}$. Ou seja, conhecemos o significado de „o pai de e assumimos que ele traduz o significado de „the father of ${ }^{\text {ee }}$. Mais à frente, quando examinarmos o tratamento de Lepore e Ludwig $(2005$; 2007) a essa questão, retomaremos esse ponto e ficará ainda mais clara a sua força.

Portanto, a diferença fundamental entre $\left(\mathrm{r}^{\mathrm{ee}}\right)$ e $\left(\mathrm{r}^{\text {eece }}\right)$, e que nos provoca a impressão de $\left(\mathrm{r}^{\text {eece }}\right)$ ser mais informativa do que ( $\left.\mathrm{r}^{\mathrm{e}}\right)$, é que ( $\left.\mathrm{r}^{\text {eee }}\right)$ usa um termo que traduz ,the father of ${ }^{\mathrm{ee}}$. Isso fica ainda mais evidente se reformulo $\left(\mathrm{r}^{\mathrm{ee}}\right)$ como $\left(\mathrm{r}^{\mathrm{eece}}\right)$.

$\left(r^{\text {eree }}\right)$. O referente da prefixação de ,the father of ${ }^{\text {ec }}$ a um termo referencial t é o valor da função referida por ,the father of ${ }^{\text {ee }}$ ou seja, o pai de t quando té o argumento da função.

\footnotetext{
${ }^{23}$ Optamos por preservar as expressões ,Annette ${ }^{e e} \mathrm{e}$, the father of ${ }^{\mathrm{e}}$ na forma em Inglês de modo a deixar explícito a distinção aqui entre a linguagem sob exame (fragmento do Inglês) e a linguagem da teoria (Português);
} 
Nesta regra modificada não parece haver dúvida de que entendemos „,the father of ${ }^{e}$ porque usamos um termo do qual conhecemos o significado e que tomamos como traduzindo a expressão em Inglês, a saber, „o pai de ${ }^{e e}$. A referência à função é reduntante na estipulação e apreensão da regra, e, por isso, descartável. O que se depreende especialmente do terceiro ponto sucitado acima, desse modo, é que atribuir uma entidade a toda expressão de uma linguagem e mencionar essa entidade no estabelecimento de uma regra composicional não é, em princípio, uma demanda necessária para fornecer o significado de um termo complexo como uma função dos significados dos termos componentes. A esse respeito pontua Davidson:

Seria inapropriado queixar-se que essa pequena teoria usa as palavras ,the father of ${ }^{\text {fe }}$ ao fornecer a referência das expressões contendo essas palavras. Pois a tarefa era de fornecer o significado de todas as expressões [...] com base nos significados das partes atômicas; não estava na barganha também fornecer os significados das partes. Por outro lado, é evidente agora que uma teoria satisfatória dos significados de expressões complexas pode não demandar entidades como os significados de todas as partes. Cabe a nós então refrasear nossa demanda sobre uma teoria satisfatória do significado de forma a não sugerir que palavras individuais tenham significado em qualquer sentido que transcenda o fato de que elas tenham um efeito sistemático sobre os significados das sentenças em que elas ocorrem (Davidson 2001[1967] 18).

A potência desta argumentação contra a utilidade de uma teoria que assinala significado como entidade cada expressão de uma língua é que Davidson não precisou de muito para ilustrar que tal estratégia não é essencial para entender o aspecto composicional do significado de expressões complexas. Bastou para se chegar a essa generalização uma teoria bastante simples de um fragmento mínimo do vocabulário de uma língua: um termo singular básico, uma expressão insaturada, e uma regra de composição. A unidade complexa resultante não chega nem a ser uma sentença. Com essa pequena lista, já é possível mostrar que se pode entrever uma teoria adequada que nos dá o significado das sentenças com base na contribuição sistemática das suas unidades constituintes sem que se tenha que entificar o significado das partes. A unidade da sentença como um significado estruturado composicionalmente não pressupõe a independência do significado das partes. O significado destas, seguindo à risca o princípio do contexto, é exaurido pela sua contribuição para o significado das sentenças. A regra $\left(\mathrm{r}^{\text {eeeg }}\right)$ esgota o papel composicional da expressão ,the faher of ${ }^{e c}$. Já as regras $\left(\mathrm{r}^{\mathrm{ee}}\right)$ e ( $\mathrm{r}^{\text {eecee }}$, por outro lado, conteriam excessos ontológicos inexpressivos, pois tudo o que queremos pode ser obtido sem a reificação que elas estipulariam.

Até aqui não fizemos uma distinção entre referência e significado. Mas podemos seguir a orientação de Frege e separar a referência de significado (sentido). Uma vez que queremos uma teoria do significado, comecemos assumindo que os significados das unidades constituintes das sentenças são distintos da sua referência. Tentemos explicar nosso entendimento do significado da 
expressão predicativa „,voare, então, dizendo que entender a palavra „,voar ${ }^{\text {‘e }}$ consiste em capturar o seu sentido. E expliquemos o significado de „Teeteto voa ${ }^{e e}$ dizendo que, dado o sentido de „Teeteto como argumento do sentido de ,voa ${ }^{e e}$, tem-se como valor o sentido de „Teeteto voa ${ }^{e e}$. Mas quão informativa é essa estratégia? Parece que não saímos do lugar ao dizer que o significado de „Teeteto voa é o significado de „Teeteto voa ${ }^{\text {ee }}$. Após exibir essa tentativa de resposta, contesta Davidson:

A vacuidade dessa resposta é óbvia. Queríamos saber o que é o significado de „Teeteto voa'; não é progresso algum ser informado de que é o significado de „Teeteto voa“. Este tanto nós sabíamos antes que qualquer teoria estivesse em vista. Na falsa explicação que acabou de ser dada, a discussão acerca da estrutura da sentença e dos significados das palavras foi inútil, pois ela não desempenhou nenhum papel ao produzir a dada descrição do significado da sentença (Davidson 2001[1967]:20).

O ponto crucial desta argumentação consiste na conclusão de que uma teoria parece não adicionar nada para o entendimento das expressões de uma linguagem investigada, ou seja, sobre nossa habilidade de capturar o seu significado, simplesmente dizendo que a elas estão associadas a entidades que são o seu significado, quando tudo o que é dito das entidades é que elas são o significado da expressão. Vejamos na próxima subseção como Lepore \& Ludwig aprofundam esta ideia.

\subsubsection{O esquema- $M$ e a contribuição de Lepore \& Ludwig.}

Como estamos à procura de uma teoria que gera sentenças que iluminem o significado das expressões de uma língua qualquer sob investigação, o natural seja tentar, então, como último recurso, construir uma teoria que tenha como consequência sentenças da forma

$$
(\alpha),, s^{\text {ee }} \text { significa (que) } p
$$

em que , $S^{\text {ee }}$ é uma descrição estrutural de uma sentença e $p$ um termo usado que deve fornecer o significado da sentença referida por ' $s$ '. Nesta estratégia, continuamos fazendo uso de significados como entidades, mas, em vez da pequena teoria da referência formulada acima, estamos explicitamente "lidando com significados em lugar de referências" (Davidson 2001[1967]: 20). Ou seja, o esquema- $M$ acima tomará entidades intensionais como conteúdos das sentenças. Para deixar as coisas mais claras, tomemos essas entidades como as entidades intensionais em Meaning and Necessity, de Carnap, ou seja, as expressões da nossa linguagem objeto, também expressam conceitos individuais, propriedades e proposições. De forma que uma sentença como „Marcos é inteligente ${ }^{e e}$, além de ser interpretada como dezendo que o indivíduo Marcos pertence à classe dos inteligentes, é também interpretada como dizendo que o conceito individual Marcos instancia a 
propriedade de ser inteligente ${ }^{24}$. Mas que fique claro que como definimos esses objetos intensionais não será essencial para tarefa aqui, que consiste em responder à pergunta: numa teoria que instancia o esquema- $\boldsymbol{M}$ acima para cada sentença da língua investigada, o recurso uma ontologia de significados desempenha algum papel explicativo essencial? Em outros termos, são os significados reificados que garantem que geremos teoremas da forma $(\alpha)$ adequados, i.e., que, munidos da teoria, compreedamos o significado de cada sentença de uma língua?

Lepore \& Ludwig (2006), aprofundando um insight já indicado em "Truth and Meaning", como ilustramos com o caso da pequena teoria da referência esboçada por Davidson, apresentam razões convincentes de que tudo o que conseguimos fazer com uma teoria que reifica significado pode ser feito por uma teoria da tradução na qual não se quantifica sobre objetos intensionais. A argumentação dos autores, baseada em exemplos de teorias do significado que obedecem ao esquema- $\boldsymbol{M}$ acima, reforça a crítica de Davidson à utilidade de uma ontologia de significados para iluminar significado, e, a meu ver, apresenta robustas evidências, difíceis de serem contornadas, contra qualquer relevância explicativa que se acredita entrever em uma teoria semântica que apela a significados como entidades. Ou melhor, se uma tal teoria fornece alguma explicação de como compreedemos os significados das expressões de uma língua, isso não se deve à reificação, mas a suposições tácitas embutidas na teoria. Sigamos então a trilha dos autores.

Em primeiro lugar, concebamos uma teoria $\mathbf{M}$ que trate as expressões de um fragmento de uma língua L como designando seus significados. Esse fragmento conterá quatro expressões: o

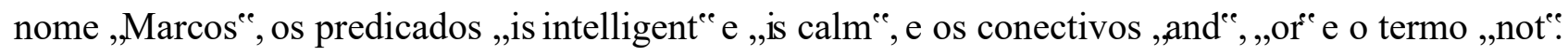
Atribuamos, em consonância com Lepore \& Ludwig (2006), os seguintes axiomas para cada uma das expressões mencionadas:
A1. Significa (,Marcose, Marcos)
A2. Significa (,x is intelligent" $x$ é inteligente)
A3. Significa (,,x is calm"e, $x$ é calmo)
A4. Significa (,,p and qee, p e q); onde ,p ee e, qe são variáveis sentenciais
A5. Significa (,not pee, não $p$ )

Em seguida, as cinco regras

R1. Para qualquer nome próprio $\beta$, para qualquer predicado $\Phi$, o resultado de colocar $\beta$ na posição de argumento em $\Phi$ significa o valor do significado de $\Phi$ dado o significado de $\beta$ como argumento.

\footnotetext{
${ }^{24}$ A ideia em Carnap é que em uma línguagem intensional, constantes individuais expressam conceitos individuais, predicados expressam propriedades e sentenças, proposições. Para uma discussão detalhada desses problemas e outros envolvendo o método de extensão e intensão de Carnap, ver o texto "The Method of Extension e Intension" (1963) de Davidson.
} 
R2. O valor de qualquer função predicativa, dado um argumento denotado por um termo referencial, é denotado pela expressão que resulta de colocar o termo referencial na posição de argumento da função predicativa.

R3. Para qualquer conectivo sentencial binário $\delta$, e qualquer fórmula $\mathrm{p}, \mathrm{q}$, o resultado de colocar $\mathrm{p}$ e $\mathrm{q}$ na primeira e na segunda posições de argumentos de $\delta$ significa o valor do significado de $\delta$ dados os significados de p e q como primeiro e segundo argumentos.

R4. Para qualquer conectivo sentencial unário $\varepsilon$, qualquer fórmula $\mathrm{p}$, o resuldado de colocar $\mathrm{p}$ na posição de argumento de $\varepsilon$ significa o valor de $\varepsilon$ dado o significado de p como argumento.

R5. O valor de qualquer conectivo sentencial para uma sequencia de argumentos denotados por uma sequencia de formulas é denotado pela expressão que resulta de colocar as formulas nos lugares de argumentos do conectivo.

A1, A2 e A3 nos dão respectivamente os significados de „,Marcos ${ }^{e e}$, ,X is intelligent ${ }^{\text {ee }} \mathrm{e}, \mathrm{X}$ is calm . Ao instanciar R1 para „Marcosee e R2 para „,X is intelligent ${ }^{\text {ee }}$, temos

(i). „Marcos is intelligent ${ }^{\text {ee }}$ significa o valor do significado de , $\mathrm{X}$ is intelligent ${ }^{\text {ee }}$ dado o significado de „Marcos ${ }^{\mathrm{ee}}$ como argumento.

Sendo que o valor do significado de , $\mathrm{X}$ is intelligent ${ }^{\text {ee }}$, dado o significado de „Marcos ${ }^{\text {ee }}$ como argumento, é Marcos é inteligente (R2), então inferimos como teorema

(ii). ,Marcos is intelligent"e significa Marcos é inteligente.

Geremos agora uma sentença com negação. Instanciando R4 para „not e e „Marcos is intelligent temos

(iii). „Marcos is not intelligent" significa o valor do significado de ,not is intelligent" como argumento.

Acrescentado R5, infere-se

(iv). „Marcos is not intelligent” significa Marcos não é inteligente.

Esse método pode ser facilmente estendido para outras expressões, como predicados relacionais e quantificadores. Mas para os propósitos em mente bastam as amostras acima para ficar claro como podemos atribuir a uma expressão complexa de uma língua um significado composto dos significados atribuídos as suas expressões constituintes. Intuitivamente, com as cláusulas acima, produzimos teoremas que corretamente nos deram os significados de „Marcos is intelligent ${ }^{\text {ee }} \mathrm{e}$ „Marcos is not intelligente. Notem que a língua na qual formulamos a teoria é o Português e a linguagem objeto é um fragmento do Inglês. Essa distinção será fundamental para o argumento. Mas antes vejamos se o fato de associarmos uma entidade a cada expressão do nosso fragmento é 
suficiente para exibir os significados das expressões complexas como uma função dos significados de suas partes e modos de composição. Em outras palavras, examinemos se o fato de assumirmos que as sentenças usadas do lado direito do termo „significae em (ii) e (iv), mas também nos aximomas (A1-A5), em função de „designareme os significados das sentenças (ou expressões) mencionadas do lado esquerdo, iluminam como compreendemos cada expressão da língua.

Para mostrar que o apelo à reificação não é suficiente, Lepore \& Ludwig (2006) propõem que modifequemos nossa teoria anterior. A ideia é ter uma teoria M' que mantenha a atribuição de significados como entidades a cada expressão da língua examinada, mas que, ao invez de traduzir as expressões do fragmento em Inglês para expressões correspondentes do Português com a mesma estrutura gramatical, associa nomes próprios às expressões , $\mathrm{x}$ is intelligent ${ }^{\mathrm{e}},, \mathrm{x}$ is calm ${ }^{\mathrm{ee}},, \mathrm{p}$ and $\mathrm{q}^{\mathrm{ee}} \mathrm{e}$ „not $p^{e e}$. Abaixo as alterações propostas:

\author{
A1 $1^{\text {ee }}$ Significa (,Marcos"e, Marcos) \\ A2". Significa (,x is intelligent" , Paulo) \\ $\mathrm{A} 3^{\text {"e }}$. Significa (,x is calm"e, Sandra) \\ A4"e. Significa (,,p and qee, Hélio) \\ A5"e. Significa (,,not pe, Laura)
}

Os nomes próprios „Paulo“, „Sandra ${ }^{e e}$, „Hélio ${ }^{c e}$ e „Laura ${ }^{\text {ee }}$ se referem aos significados das expressões mencionadas. Portanto, „Paulo ${ }^{\text {ee }} \mathrm{e}$ „Laura ${ }^{e e}$ são nomes dos significados das expressões „, $\mathrm{X}$ is intelligent ${ }^{\mathrm{ee}} \mathrm{e}$, not $\mathrm{p}^{\mathrm{ee}}$, respectivamente. De maneira que, aplicando R2 e R4, derivamos

(ie). „Marcos is intelligent" significa o valor de Paulo dado Marcos como argumento.

(iii"). ,Macos is not intelligente significa o valor de Laura dado o valor de Paulo dado Marcos como argumento.

Evidentemente que (i') e (ii $\left.{ }^{\text {ie }}\right)$ não nos fornecem quaisquer pistas para a compreensão dos significados das expressões do fragmento do Inglês que investigamos. Contudo, na teoria T' continuamos usando as expressões do lado direito do termo ,significa ${ }^{e e}$ para designar o significado das expressões mencionadas do lado esquerdo. Então, o que ocorreu de errado? Qual a diferença fundamental entre as duas teorias que assegura o sucesso da primeira e o fracasso da segunda? Tendo as duas teorias bastante simples formuladas, é bem claro, imediato, o que corre. A primeira teoria usa expressões em Português que têm as mesmas categorias gramaticais das expressões da língua examinada e que se assume que são traduções em Português das expressões em Inglês. Fundamentalmente, é por compreedermos a metalinguagem (linguagem na qual se fala da linguagem examinada) e assumirmos tacitamente que as expressões nela usadas traduzem os termos mencionados da linguagem objeto (linguagem da qual se fala), que nos permite compreender as 
expressões cujos significados queremos apreender. Nela, então, coordenamos sistematicamente expressões do fragmento em Inglês com expressões em Português que as traduzem, i.e., que são tomadas como sinônimas. Ou seja, do lado esquerdo de instanciações do esquema „s significa (que) $\mathrm{p}^{\text {ee }}$ mencionamos uma expressão/sentença da linguagem objeto, no caso um fragmento do Inglês, e do lado direito usamos expressões/sentenças do Português para especificar seus significados. São a compreensão prévia do Português e a capacidade de discernir qual expressão do Português associar com a expressão do Fragmento do Inglês que realizam o trabalho de capturar os significados da linguagem objeto. Para ilustrar isso de maneira mais sintética, tomemos novamente a sentença „Marcos is intelligent ${ }^{e}$. Pode-se conceber uma teoria que forneça duas traduções para ela na forma de um esquema- $M$ :

(i). „Marcos is intelligent ${ }^{\mathrm{ee}}$ significa (que) marcos pussui a propriedade Inteligente.

(ii). „Marcos is intelligent ${ }^{\mathrm{ee}}$ significa (que) marcos é inteligente.

Nesses exemplos, o termo ,propriedade $e^{e e}$ seria desnecessário, uma vez que a neutralidade de (ii) evitaria o apelo a esta noção e mesmo assim seria, como tradução, tão informativo quanto (i). Logo, em vez de duas traduções na teoria para o termo ,intelligent ${ }^{e e}$, é suficiente, mas também preferível, tendo em conta o critério da simplicidade, adotar apenas a formulação neutra ,inteligente ${ }^{e}$.

Para iluminar os significados das expressões do fragmento em Inglês foi suficiente traduzílas adequadamente (i.e., mapeá-las em termos comumente considerados sinônimos) para uma língua que conhecemos. A atribuição de entidades às expressões é completamente secundária, parasitária, e nada essencial. O que assegurou a interpretatividade da primeira teoria não é saber os fatos que ela expressa, mas saber esses fatos mediante uma língua que previamente se conhece. Conceba, por exemplo, uma teoria $\mathbf{M}^{*}$ que define uma sequência ordenada $\mathrm{P}$ das proposições expressas por uma classe $S$ de sentenças de uma linguagem L, tal que para cada sentença $s$ de $S$ deriva-se um teorema da forma „s expressa a n-ésima proposição $p$ de $P^{\text {ee }}$, onde , , ${ }^{\text {ee }}$ é substituída por uma descrição estrutural de uma sentença de $S$ e ,ne por um numeral que indica a posição que a proposição expressa por $p$ ocupa na sequência $P$. Em tal procedimento, se não for possível correlacionar as proposições (com índices) com uma linguagem $L^{*}$ que conhecemos e cujas sentenças traduzem as sentenças de $S$, não podemos utilizar os teoremas de $\mathbf{M}^{*}$ para entender o significado das sentenças de $S$. Ou seja, se não conhecemos L* e não a especificamos como uma linguagem de $\mathbf{M}^{*}$, ainda que esta possa especificar que o significa de uma sentença $s$ é um proposição $p_{\mathrm{n}}$, ou seja, mesmo que ela exiba pares de sentenças da linguagem estudada com proposições expressas por essas sentenças, ela o faz de um modo que não podemos discernir. É a esta constatação que a segunda teoria, 
apresentada de forma bem direta, recorrendo ao mero emprego de nomes próprios para designar significados, deve conduzir. O procedimento de uso de nomes se referindo aos significados das expressões mencionadas - mesmo que combinado a um método de correlacionar uma proposição a cada sentença da linguagem para a qual $\mathbf{M}^{\prime}$ é uma teoria, como indicamos com $\mathbf{M}^{*}$ - inviabilizou qualquer compreensão dos significados das expressões da linguagem objeto.

As duas teorias ilustradas são mobilizadas para argumentar que a reificação de significados não foi suficiente para cumprir o que se espera que uma ontologia de significados cumpra em uma teoria semântica. Mas também o apelo a essas entidades não é necessário, pois tudo o que foi realizado com a primeira teoria pode ser feito sem a reificação. Para isso, basta tratar o esquema- $\boldsymbol{M}$ (,s significa $p^{e €}$ ) não como uma relação entre uma expressão e uma entidade abstrata, mas como uma relação entre uma expressão mencionada e outra expressão usada que a traduz. Logo, a questão fundamental que se coloca é se uma análise semântica não pode ser empreendida sem o uso de permos como ,propriedade ${ }^{e e}$, ,proposição ${ }^{e e}$, etc. A semântica proposta por Davidson é uma tentativa de uma resposta positiva a essa problema.

Mas neste ponto, pode emergir o questionamento de que haveria uma diferença crucial entre a primeira teoria e uma teoria da tradução: a primeira estabelece o suficiente para explicar o significado das expressões, pois, além de fornecer uma tradução, correlaciona a expressão mencionada com a usada por meio de uma correferência: a referência da expressão denotada por „,se no esquema- $\boldsymbol{M}\left(, s\right.$ significa $\left.p^{e c}\right)$ na primeira teoria é a mesma da expressão $p$ usada do lado direito. Ou seja, a primeira teoria diria também o que assegura a tradução: um mesmo conteúdo como significado. Em contrapartida, uma mera teoria da tradução, por não fazer referência ao conteúdo partilhado pelas expressões da linguagem objeto e da metalinguagem, não seria suficiente. A essa ponderação respondem Lepore \& Ludwig (2006):

Mas essa diferença tem a ver somente com o fato de que usar expressões para se referir aos seus próprios significados faz parecer que para entender os enunciados de significado devemos entender as expressões usadas, de forma que o entendimento da teoria nos dá o conhecimento dos significados das traduções relevantes na metalinguagem das sentenças da linguagem objeto. Contudo, na verdade, o domínio que temos sobre que entidade deve ser associada com uma expressão da linguagem objeto acorre por meio de uma descrição que podemos construir usando a expressão da metalinguagem, por exemplo, no caso [...] „o significado de "is ambitious"e. Referência ao significado, o que quer que ela seja, não é relevante. Pensamos sobre o significado dessa maneira, mas nós entendemos a expressão que usamos para capturá-lo, e este entendimento e a pressuposição de sinonímia são o que nos permitem entender a expressão da linguagem objeto (Lepore \& Ludwig 2006: 332). 
A eficácia da introdução de significado como entidade é ilusória. E esse engano é motivado por escolhermos termos na metaliguagem que são entendidos como traduções dos termos da linguagem objeto. Numa teoria em que se usa, para traduzir uma expressão da linguagem objeto, um termo na metalinguagem na mesma categoria semântica, tem-se a impressão de que é se referindo a algo que capturamos o significado das expressões entre aspas. O mecanismo de eliminar as aspas em „sentenças de significado " que empregam descrições (tais como „o significado de "x is intelligent” é $x$ é inteligente $e^{e q}$, provoca a ilusão de que o conhecimento das entidades postuladas na teoria é suficiente para entender os termos da linguagem objeto. Essa ilusão de utilidade da reificação é motivada, em grande medida, pelo fato de que nas línguas naturais falamos de significados como se fossem entidades às quais nos referimos. "Pensamos sobre significado dessa maneira". Somos induzidos, pelo próprio uso que fazemos das línguas naturais, a falar como se existissem coisas como significados. Sentenças como „o significado da palavra "chuva eee em Finlandês é ___ parecem, a princípio, ter a mesma estrutura de „o irmão do Paulo é ___ “. Assim como a pergunta „Qual o significado da palavra “chuva” em Finlandês"e, que sugere ter a mesma estrutura de „Quem é o irmão de Paulo? $?^{e e}$, uma vez que se apresenta como uma dúvida sobre um $x$ cujo valor é uma entidade que se quer identificar. Tal processo de reificação é tão produtivo em língua natural que podemos mobilizar todo o aparato de reificação disponível em nossas linguas para se "ferir" a supostos significados. Aparentemente quantificamos sobre significados em sentenças como

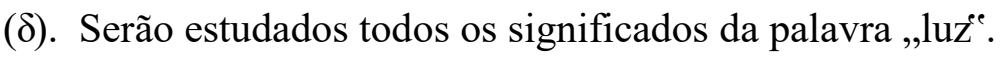

$\left(\delta^{e e}\right)$. Nem todo significado usado por Paulo é preciso.

E até empregamos pronomes demonstrativos para falar de significados:

$\left(\delta^{\text {ceeg }}\right)$ Este significado é o correto.

Tais modos de dizer em língua natural encorajaram, em grande parte, (i) modelos teóricas que adotam uma reificação do significado, assim como (ii) a tendência de interpretar tais teorias - como a nossa primeira micro-teoria - como dizendo algo essencial sobre o significado ao reificá-lo. Mas o aspecto crucial em teorias semelhantes ao nosso primeiro caso, como demonstradado, é que elas coordenam sentenças da linguagem objeto com sentenças da metalinguagem que as traduzem. Em essencial, um processo nada diferente de uma "uma teoria da tradução junto com o conhecimento de uma das línguas" (Lepore \& Ludwig 2006:333-334). Um mecanismo que, sem qualquer forma de quantificação sobre significados, atinge o mesmo propósito, pois é a própria combinação de uma 
expressão com outra que a traduz e que entendemos que realiza todo o trabalho. Referência a significado não é o que nos permitiu entender o aspecto composicional do significado do fragmento do Inglês que adotamos como nossa linguagem objeto. Dessa constação, podemos inferir, com suficiente segurança, a generalização de que a reificação não é necessária nem suficiente em qualquer teoria composicional do significado.

Guiado pela constatação da inutilidade explicativa do uso de uma ontologia de significados, conclui Davidson em "Truth and Meaning":

Paradoxalmente, uma coisa que significados parecem não fazer é azeitarem as engrenagens uma teoria do significado - contanto que exijamos ao menos de tal teoria que, de um modo não trivial, forneça o significado de toda sentença da língua. Minha objeção a significados na teoria do significado não é que eles são abstratos ou que suas condições de identidade são obscuras, mas porque eles não demonstram nenhuma utilidade (Davidson 1990 [1967]: 20-21).

Há dois fatos a serem considerados aqui. Em primeiro lugar, o fato de que é principalmente à luz do contexto de "Truth and Meaning" em que Davidson expõe suas objeções à reificação dos significados que um entendimento correto dessa posição pode ser formulado. Nela Davidson não está propondo eliminar qualquer noção de significado, muito menos de outros conceitos associados, como tradução e sinonímia. O que o fragmento acima sustenta é que em uma teoria do significado a introdução de significados como entidades não possui nenhuma relevância explicativa. Todo o trabalho de uma teoria que venha a fornecer um método efetivo para se gerar composicionalmente o significado de uma sentença arbitária de uma língua precisa, portanto, ser empreendido sem apelo à reificação. É isso que Davidson afirma quando diz: “contanto que exijamos [...] de tal teoria que, de um modo não trivial, forneça o significado de toda sentença da língua". O modo "não trivial" consiste justamente em um método que chegue ao significado sem entificar o mesmo. E não uma estratégia que substitua uma teoria do significado.

O segundo ponto da passagem é bastante importante de se destacar também, em parte porque dialoga com posições filosóficas fortes na tradição analítica e em parte porque ajuda a esclarecer a motivação principal da posição adotada por Davidson com base no argumento da utilidade. Ela consiste na preocupação de Davidson em marcar lugar quanto à natureza da sua rejeição da reificação no contexto do debate sobre a adoção de entidades abstratas em uma teoria. Esta rejeição não é da ordem de qualquer ceticismo quanto à existência de objetos abstratos, respaldado pela ausência de critérios rigorosos e não circulares de individuação dessas entidades que permitam que o princípio de identidade seja aplicado a elas. Aqui Davidson, em especial dialoga com a prescrição, bem marcada nos trabalhos de Quine (1948; 1960), segundo a qual as entidades postuladas em uma teoria precisam ser acompanhadas por condições de individuação 
precisas para que as aceitemos como povoando a ontologia da teoria. E que a ausência dessas condições para muitas entidades abstratas, entre elas proposições e propriedades (as quais são geralmente consideradas como significados de sentenças e expressões predicativas, respectivamente ${ }^{25}$ ), consiste numa considerável evidência em suporte do ceticismo quanto a sua existência. Davidson, então, intenta se distanciar desta postura quando destaca que a motivação central para o abandono de significados reificados é "porque eles não demonstram nenhuma utilidade" (Davidson 2001[1967]: 20-21), e não em decorrência de uma austeridade ontológica diretamente vinculada a razões independentes do critério de utilidade. ${ }^{26}$

Algumas lições essenciais para o projeto de fornecer uma teoria composicional do significado para uma língua natural emergem de toda essa discussão motivada pelo argumento da utilidade. Uma teoria cujo objetivo é iluminar o que qualquer sentença arbitrária de uma língua significa com base em axiomas sobre as expressões primitivas da língua e que visa assegurar que algum conhecimento da teoria é fundamental para o entendimento da linguagem objeto, precisa combinar sentenças da linguagem objeto com sentenças da metalinguagem que operam como traduções das sentenças da linguagem objeto. Não há como capturar em uma teoria da forma entrevista por Davidson os significados das expressões de uma língua natural sem usar termos tomados como tendo o mesmo significado. O entendimento das expressões e das sentenças da

\footnotetext{
${ }^{25}$ No caso das proposições, por exemplo, Quine sustenta a tese segundo a qual não há "um padrão de quando falar de proposições como idênticas e quando como distintas" (Quine 1960: 200). Isto é, não conseguimos formular condições precisas para a identidade de proposições. Poderíamos, pontua Quine, se caracterizarmos proposições como os significados das sentenças, definir uma proposição como a classe de todas as sentenças sinônimas, quer internas a uma língua quer entre todas as línguas. De maneira que duas proposições seriam idênticas se, e somente se, tivessem por membros as mesmas sentenças sinônimas. Não temos, contudo, também um critério preciso de individuação de sentenças sinônimas. Sinonímia é um conceito semântico que não estabelece determinações precisas, mas apenas sugere proximidades, semelhanças gradativas entre termos e sentenças. Em contrapartida, identidade não é uma questão de grau. Identidade é um princípio absoluto. Dois objetos não são mais idênticos ou menos idênticos. "Identidade, propriamente chamada, desconhece gradações" (Quine 1960: 203). Embora na linguagem cotidiana usemos a expressão ,idêntico "e para falar de semelhança, o critério de identidade que Quine tem em mente é um critério de individuação que faça valer o princípio de identidade para os objetos de uma linguagem. Assim, como formular uma definição de identidade para proposições, sendo proposições os significados das sentenças, mobilizando a noção de semelhança de significado, quando nem sequer teríamos uma noção substancial do que é significado? Como pode ser visto, as posições de Quine, se corretas, colocam consideráveis desafios para a viabilidade de uma teoria semântica para as línguas naturais. Ainda que no decorrer da tese alguns desses pontos reapareçam, eles não serão examinados com o rigor que merecem. Isso porque para tanto exigiriam uma tese concentrada apenas neles.

${ }^{26}$ A referência de Davidson, na passagem citada, à posição de que supostas entidades cujas "condições de identidade são obscuras" (Davidson 2001[1967:20-21) devem ser descartadas, será retomada quando tratarmos da ontologia de eventos proposta por Davidson para incorporar na sua teoria semântica uma explicação composicional dos advérbios, sentenças de ação e sentenças causais que capture relações inferenciais fundamentais entre sentenças. Davidson tentará construir um critério de identidade entre eventos em termos de relações causais que, mais tarde, por causa de uma objeção de Quine ao mesmo, apontando sua circularidade, será abandonado, sem uma outra solução seja proposta. Contudo, a falta de um critério não será suficiente para Davidson jogar fora a quantificação sobre eventos na descrição da forma lógica de sentenças de ação e com advérbios, uma vez que, para ele, descartar a reificação de eventos implicaria não somente a recusa de uma estratégia que consegue explicar, pela primeira vez, consistentemente um fragmento considerável das línguas naturais (i.e., sentenças de ação e causais modificadas por advérbios e as redes inferências que estabelecem), mas também a posição de que todas as sentenças desse fragmento seriam falsas. Sobre este tópico, ver capítulo III.
} 
linguagem objeto é atingido justamente por esse processo de usar expressões com o mesmo significado. Mas o propósito de Davidson não é de equiparar uma teoria do significado com uma teoria da tradução. Isso porque uma teoria que instancia o esquema- $M$ acima para uma sentença qualquer diz apenas que a sentença referida pela descrição que substitui „, ${ }^{\text {ee }}$ tem o mesmo significado que a sentença que substitui,$p^{\text {ee }}$. Ela apenas equipara sentenças na linguagem objeto com sentenças na metalinguagem que as traduzem. E as etapas de "composição" de uma sentença são reduzidas a combinar partes da sentença com partes sinônimas na metalinguagem. A impressão de que tal teoria elucida o aspecto composicional do significado é ilusória. O máximo que se atinge é um método sistemático de mapear sentenças em sentenças que as traduzem via o assinalamento de traduções, na metalinguagem, às expressões componentes das sentenças da linguagem objeto. $\mathrm{O}$ fato adicional de se conseguir em muitas traduções usar expressões da mesma forma gramatical dos termos traduzidos acentua essa impressão de que se está em posse de uma teoria composicional. Mas esse recurso não exaure o papel de uma teoria do significado, porque não diz nada sobre a composicionalidade das condições de verdade das sentenças, um aspecto essencial do significado, na leitura de Davidson. E, presumivelmente, não exibe como as expressões de uma língua natural operam sistematicamente para determinar as condições de verdade das sentenças nas quais ocorrem. Um manual de traduação entre duas línguas não é suficiente para fornecer uma teoria do significado. Ele no máximo fornece uma explicação de como um falante do Português pode mapear sistematicamente as sentenças de uma língua que está aprendo, por exemplo, o Hindi, em sentenças do Português. Um manual de tradução apenas ilumina a competência semântica que temos de traduzir uma língua para uma outra da qual temos conhecimento. Dado isso, é crucial entender que o projeto de Davidson demanda que uma teoria do significado torne manifestas mais estruturas do que as que são suficientes para elaborar meramente um manual de tradução.

O otimismo de Davidson é de que uma teoria do significado, mediante o emprego de uma teoria interpretativa da verdade inspirada em Tarski, pode cumprir simultaneamente ambos os papéis: traduzir e exibir as condições de satisfação das expressões subsentenciais. A teoria da verdade deverá possuir axiomas na metalinguagem que usam termos que traduzem as expressões da linguagem objeto. E, por meio do uso desses termos na composição das condições de verdade das sentenças, fornecer, na estrutura de uma prova, sentenças-T interpretativas, i.e., em que a sentença que substitui a variável „p pe no esquema “ “s’ é verdadeira sse p” traduz a sentença descrita pela expressão que substitui , $s^{\text {ee }}$. O emprego de uma teoria da verdade a serviço de uma teoria semântica iluminaria o mecanismo composicional do significado porque, atribuindo, nas provas das sentenças$\mathrm{T}$, condições de satisfação (axiomas) e referência aos primitivos semânticos de uma língua, faz uso (i) de expressões na metalinguagem que os traduzem e (ii) exibe como as propriedades extensionais 
dos termos e os seus modos de combinação fixam as condições de verdade das sentenças. A vantagem que Davidson enxerga na teoria que advoga, portanto, é que ela consistiria numa estratégia que nos informaria sobre a contribuição sistemática das expressões das línguas naturais para o significado das sentenças e as redes inferencias que se estabelecem entre elas. Como veremos, em uma teoria composicional do tipo vislumbrada, o significado de cada sentença $s$ de uma linguagem objeto não será dado só pelo teorema que contêm s, mas pela classe infinita de teoremas de todas as outras sentenças que contenham os componentes subsentenciais de $s$.

O sistema semântico que Davidson propõe, portanto, não consiste, como equivocadamente se costuma apresentá-lo, em um método que persegue a eliminação da noção de que uma camada do significado das sentenças, do conteúdo informacional (sentido, intensão) que elas expressam. O que Davidson sustenta é que se pode construir uma teoria em que a admissão da distinção entre referência e conteúdo informacional não implica o comprometimento com este último como entidade. A primeira menção à possibilidade de que se possa entrever tal teoria aparece já no primeiro texto conhecido de Davidson, que ainda é anterior ao seu contato com os trabalhos de Tarski sobre verdade, sobretudo a Monografia do lógico polonês. Em 1954, Davidson apresenta um texto, na Universidade de Berkley, Califórnia, sobre o método de intensão e extensão de Carnap. Esse texto sofrerá várias modificações até assumir uma forma definitiva publicada em $1963 .{ }^{27}$ Embora o artigo se caracterize mais como uma exposição minuciosa e crítica da semântica de Carnap, situando-a dentro de uma classificacão das semânticas existentes, e poderando sobre algumas de suas vantagens e desvantagens, nele Davidson inclui, nesta própria tipologia que propõe, um possível método, ainda não elaborado, mas que viria a se tornar a ambição do seu projeto. Diz Davidson:

Alguns sistemas não aceitam distinção entre referência e significado (ou extensão e intensão, ou sentido e nominatum). Para tais sistemas só há referência. Outros sistemas admitem uma distinção, mas negam que ter um significado ou intensão envolve uma entidade, $e$, portanto, negam a existência de expressões que se referem a tais entidades. Sistemas destes dois tipos podemos chamar de sistemas semânticos de primeiro nível. ${ }^{28}$ Outros sistemas, como o de Church e Frege, envolvem uma série infinita de níveis interligados de expressões e entidades, com as entidades em cada nível servindo como os sentidos de algumas (possíveis) expressões e nominata de outras (possíveis) expressões. Podemos dizer que tais sistemas possuem níveis semânticos infinitos. Por fim, seria em teoria possível parar as séries em algum ponto ao negar às expressões em algum nível um sentido ou um nominatum, uma extensão ou uma intensão. Tal sistema seria um sistema semântico de nível-n, onde n é o número de níveis de entidades. Deve ser observado que essa classificação não tem

\footnotetext{
${ }^{27} \mathrm{O}$ texto é publicado, na data menicionada, sob o título „,The Method of Intension and Extension ${ }^{\text {ee }}$, no livro The Philosophy of Rudolf Carnap, editado por Paul Arthur Schilpp. O livro é o Volume XI da famosa coleção The Library of Living Philosophers, publicada pela Cambridge University Press.

${ }^{28}$ A parte em itálico é nossa.
} 
nada a ver com os tipos de entidades envolvidas (exceto que algumas devem ser os significados e intensões quando o sistema é mais do que o de primeiro nível); e que a obtenção de níveis acima do segundo depende inteiramente do fato de que algumas entidades servem tanto como extensão quanto intensões. O método de extensão e intensão de Carnap, como seu nome talvez sugere, é um sistema semântico de nível-2 (Davidson 1963: 339-400).

A tipologia acima é bastante elucidativa de como Davidson entenderá o seu projeto e como ele o situará em relação a outras estratégias de elaboração de uma semântica sistemática. A diferenciação crucial entre as semânticas que assumem uma distinção entre referência e significada (sentido ou intensão) se assenta na reificação ou não do conteúdo informacional caracterizado como intensional. As semânticas de Frege, Church e Carnap adotariam uma reificação deste conteúdo, e uma semântica de tipo davidsoniana negaria que o apelo às noções de sentido ou intensão se traduza necessariamente em tomá-las como entidades. A tarefa de Davidson é justamente articular um quadro teórico que demonstre que a reificação do significado não é essencial para um sistema semântico. Davidson classifica as semânticas de Frege e Church como sistemas de uma hierarquia infinita de entidades. Isso porque, tais métodos, implicitamente, como no caso de Frege, ou explicitamente como na semântica intensional de Church, permitem que, em contextos intensionais em que novos verbos de atitudes proposicionais tomam como argumento sentenças que já contêm verbos deste tipo, novos sentidos ou intensões são introduzidos para servirem como conteúdos semânticos e referências das expressões. Isso é gerado justamente pelo aspecto iterativo desses verbos. O método de Carnap consiste numa tentativa de bloquear essa hierarquia no nível-2, i.e., toda expressão terá associada a ela apenas uma extensão e uma intensão. Em vista dos desafios que os problemas colocados pelos contextos intensionais gerados pelas sentenças de atitude proposicional impõem para qualquer teoria do significado, em especial para uma semântica do tipo davidsoniana, eles serão analisados, como já dito, no capítulo IV. O sucesso do projeto dependerá em grande parte de uma solução para tais contextos que assegure que eles recebam um tratamento que não tome sentenças sob o escopo de verbos de atitude proposicional como se referindo a proposições. Davidson acredita ter fornecido uma análise alternativa para essa classe de sentenças. Mas por ora, o que deve ficar em destaque com a passagem acima é que Davidson, já no seu primeiro texto, indica a natureza do que viria a ser o seu projeto de uma teoria do significado. Leituras que descrevem o seu projeto como uma semântica que dispensa as noções de significado, sentido, intensão, além de se revelarem interpretações prescipitadas dos seus textos programáticos (TMLL e TM), parecem mostrar um desconhecimento do contexto maior dos textos sobre semântica que compõem a sua obra filosófica. Davidson não partilha da tese extensionalista de que a atribuição de intensões às expressões de uma língua natural não é um procedimento que pode ser empiricamente testado pela observação do comportamento linguístico, e que por isso - mas também 
pelo aspecto "nebuloso" dos conceitos ditos intensionais, manifestado na dificuldade de fornecer definições para eles - seriam de duvidoso valor científico. O conceito de conteúdo informacional, quer seja rotulado de intensão ou sentido, é uma ferramenta fundamental, na teoria proposta por Davidson, para a análise do significado. Trata-se de uma noção útil e indispenável para uma análise semântica de uma língua natural. Sem o emprego da noção de conteúdo informacional e conceitos associados, como sinonímia e tradução, não é possível de se formular critérios de adequação formal e empírica para uma teoria da forma elaborada por Davidson. A distinção, para Davidson, do seu projeto em relação a teorias neo-fregeanas, é que é possível construir uma semântica formal que, ao empregar o conceito de conteúdo informacional e identificá-lo com o significado das sentenças, não se compromete com a reificação deste conteúdo. A mudança de foco no projeto de Davidson consiste em distanciar uma teoria do significado do empreedimento de tentar dizer que tipos de coisas são sentidos e intensões, em direção à ideia de buscar interpretar as sentenças de uma linguagem objeto procurando por um método que assegure o emprego satisfatório das noções semânticas de sinonímia e tradução. A ambição de Davidson não é de fornecer critérios de definição dessas noções, ou seja, de elaborar definições formalmente adequadas delas, mas sim de iluminar a relação entre os conceitos semânticos empregados na teoria e as disposições dos falantes de uma lingua para produzir e, especialmente, interpretar enunciados. A ambição geral do projeto é de que se conseguirmos formular condições que assegurem a interpretatividade de uma teoria da verdade, e que demonstrem como os conceitos mencionados, centrais em uma teoria do significado, podem ser empiricamente empregados sem incorrer na postulação de entidades intensionais, então poderemos fornecer um sistema semântico que, ainda que mantenha uma distinção entre referência e sentido, pode ser compreendido como uma alternativa a teorias de inspiração fregeana, em virtude da sua imunidade uma ontologia de sentidos. 


\section{CAPÍTULO II: A CONCEPÇÃO SEMÂNTICA DE VERDADE DE ALFRED TARSKI E AS OBJEÇÕES DO LÓGICO À SUA APLICAÇÃo ÀS LÍNGUAS NATURAIS.}

\section{Considerações iniciais.}

O projeto de Donald Davidson consiste em mobilizar a concepção semântica de verdade para linguagens formalizadas, construída pelo lógico e matemático polonês Alfred Tarski, como um veículo de uma teoria composicional do significado para as línguas naturais. A definição de verdade em termos de satisfação proposta por Tarski, na perspectiva de Davidson, pode ser posta a serviço de uma semântica formal das línguas naturais que intenta exibir como, em grande medida o significado das sentenças de uma língua natural é determinado por suas estruturas, i.e., pelos significados das suas expressões constituintes e pelo modo em que essas expressões se combinam. A definição de verdade Tarski em termos da relação de satisfação abriu a possibilidade de, pela primeira vez, defende Davidson, termos um método formal à disposição de uma teoria composicional empírica do significado para as línguas naturais e que pode ser empregado para descrever a habilidade dos falantes de uma língua em produzir e interpretar uma quantidade, em pontencial, infinita de novas sentenças.

O otimismo de Davidson com a possibilidade de adaptar o método tarskiano a uma teoria semântica das línguas naturais vincula-se à vantagem filosófica, no emprego de uma teoria da verdade do tipo tarskiana, de evitar reificar significados quer quantificando sobre eles quer tomando-os como entidades referidas pelas expressões da linguagem; estratégias que Davidson descarta, como demonstrado no capítulo precedente, argumentando contra a sua utilidade para a construção de uma teoria composicional do significado nas línguas naturais.

De início, no entanto, o otimismo teórico de Davidson já é bastante controverso. Isso porque ele intenta usar uma teoria da verdade como a de Tarski para iluminar o aspecto composicional do significado na linguagem ordinária. Indo na contramão das expectativas do próprio lógico polonês, que, no conjunto de artigos em que apresenta e defende sua definição ${ }^{29}$, esperou demonstrar com

\footnotetext{
${ }^{29}$ Os trabalhos fundamentais de Tarski, entre eles a sua monografia "The Concept of Truth in Formalized Languages", estão compilados no livro "Logic, Semantics, Metamathematics: papers from 1923 to 1938”, cuja primeira edição data de 1956, pela Oxford University Press. Nele constam 17 artigos de Tarski traduzidos para o Inglês por J.H. Woodger, e pela primeira vez juntados em um livro. Usarei como referência a edição revista de 1983 (segunda e última revisão do conteúdo), pela Hackett Publishing Company. O próprio Tarski colaborou nas mudanças que ocorrem nesta edição, que essencialmente são alterações de defeitos de tradução, clarificação de passagens e correções de erros de impressão constatados na primeira edição. Quanto ao conteúdo, não houve nenhuma ateração, permanecendo os 17 artigos contemplados na edição de 1956. As citações, no presente capítulo, das passagens dos trabalhos de Tarski são traduções nossas das versões em Inglês contidas na edição de 1983. Para a tradução de algumas passagens cotejamos nossa versão com a boa tradução para o Português dos textos semânticos de Tarski feita pelos professores Cezar Augusto Mortari e Luiz Henrique de Araújo Dutra, Jesus de Paula Assis e Celso Reni Brada, no livro A concepção semântica de verdade: textos clássicos de Tarski, 2006, publicado pela Editora Unesp.
} 
relativa exaustividade que, dada a própria "natureza inconsistente" das línguas naturais, sua definição de verdade estaria de antemão impossibilitada de ser estendida a elas.

Dado o papel indispensável e nuclear que uma teoria da verdade inspirada em Tarski desempenha no projeto de Davidson, entendo que, para uma profunda apreciação e exame crítico do projeto, em especial para o leitor não familiarizado com a concepção semântica de verdade elaborada pelo lógico polonês, é importante dedicar um capítulo a ela. Para tanto, foi preciso percorrer com certa exaustão as etapas essenciais de construção da definição, de maneira a explicitar as vantagens técnicas que Davidson entreve no edifício construído por Tarski. Além disso, contrastando o otimismo de Davidon com o ceticismo de Tarski quanto à aplicação do seu método à linguagem ordinária, espero expor também aqui os problemas que Tarski acredita comprometer o emprego da sua definição para a linguagem ordinária. Com isso, prepara-se o terreno para o terceiro capítulo da tese, onde serão investigados os problemas, desafios e possíveis limites que emergem do projeto davidsoniano e que pedem soluções para o próprio sucesso do projeto. Uma parte substancial do capítulo III será dedicada a testar a teoria semântica de Davidson contra fenômenos linguísticos que o próprio filósofo identifica como prementes e que devem receber um tratamento satisfatório pela teoria se esperamos que ela tome a forma de uma semântica empírica.

\section{A Semântica em Tarski.}

A formulação da sua concepção semântica de verdade, definida em termos de outro conceito semântico, o de satisfação, é parte de um projeto maior do lógico polonês, que consiste em estabelecer os fundamentos de uma "semântica científica", nas palavras do próprio Tarski. Essa semântica terá um escopo de aplicação bastante circunscrito: uma disciplina que trata fundamentalmente de conceitos que estabelecem relações entre expressões de uma linguagem e determinados objetos. Entre tais noções estariam os conceitos de referência, denotação, designação, definição, verdade e satisfação, todos eles conceitos que estabelecem conexões entre termos línguísticos e objetos, entre linguagens e domínios de objetos sobre os quais as linguagens falam. Em "The Establishment of Scientific Semantics" (1983 [1956]) ${ }^{30}$, Tarski define o domínio da Semântica como constituindo

[...] a totalidade das considerações que dizem respeito aos conceitos que [...] expressam certas conexões entre as expressões de uma linguagem e os objetos e

\footnotetext{
${ }^{30}$ Este artigo é um resumo de uma comunicação de Tarski realizada no Congresso Internacional de Filosofia Científica, em Paris, 1935. Primeiramente, este texto apareceu numa versão em Polonês, na revista Przegląd Filozofizny, volume 39 (1936), p. 50-57.
} 
estados de coisas a que se referem tais expressões. Como exemplos típicos de conceitos semânticos, podemos mencionar os conceitos de denotação, satisfação e definição [...] (Tarski 1983 [1956]: 401).

Tarski visa estabelecer a semântica como uma disciplina respeitável cientificamente, caracterizando de maneira precisa os conceitos semânticos. Ele estava convicto de que a Semântica poderia ser uma disciplina rigorosa e consistente, no sentido de que os conceitos no seu domínio poderiam ser definidos de maneira não circular e não pressupondo noções que ainda não receberam definições. Paralelo a isso, e mais importante, Tarski intenta demonstrar que esses conceitos não engendram necessariamente contradições, antinomias. O que faltaria era um método ou métodos adequados de definição e aplicação desses conceitos de maneira a não incorrer em paradoxos. Aqui reside uma constatação determinante para a inovação do seu pensamento. Tarski identifica que tentativas anteriores de definir tais conceitos falharam e levaram frequentemente a antinomias em decorrência da atitude de "não se ter em mente que os conceitos semânticos têm um caráter relativo, que eles devem sempre estar relacionados a uma linguagem particular" (Tarski 1983 [1956]: 402) e que “[...] a linguagem sobre a qual falamos não precisa de nenhum modo coincidir com a linguagem $n a$ qual falamos" (idem). O primeiro passo para se evitar contradições será justamente o requerimento de que a semântica de uma linguagem deve ser feita não na própria linguagem, mas em uma metalinguagem que a tem como objeto. A análise das antinomias realizada por Tarski, em especial a antinomia do mentiroso, mostra que os conceitos semânticos devem pertencem à metalinguagem, que eles "simplesmente não têm lugar na linguagem à qual se relacionam, que a linguagem que contém sua própria semântica, e na qual valem as leis usuais da lógica, inevitavelmente deve ser inconsistente" (idem). ${ }^{31}$ Como examinaremos mais à frente, é precisamente a analise das premissas nas quais a antinomia do mentiroso se baseia que motivará Tarski a ensaiar a construção de uma semântica teórica e uma definição consistente de verdade.

$\mathrm{Na}$ edificação do seu método, que consiste em dar uma resposta positiva a um problema abordado até então de forma bastante negativa - o problema da definição de verdade - Tarski reiteradamente utilizará as línguas naturais como exemplos de linguagens que limitariam, de partida, qualquer projeto inicial de uma definição rigorosa e consistente de verdade que intente estender a definição para a linguagem ordinária e linguagens que apresentam propriedades similares

\footnotetext{
${ }^{31}$ Independentemente da questão discutível de se Tarski abraçou por completo a doutrina do fisicalismo, bastante difundida pelos positivistas lógicos ao final da década de 1920, segundo a qual todos os conceitos de valor científico e intelectual deveriam ser definidos completamente em termos de conceitos lógico-matemáticos e das ciências físicas, é bastante reconhecido que Tarski pretendia reduzir conceitos semânticos a conceitos lógico-matemáticos. No caso da sua definição de verdade, esta será definida em termos de satisfação, e satisfação em termos de relações entre expressões de uma linguagem e sequências infinitas de objetos. Não cabe aqui discutir se Tarski atingiu esta estratégia, mas é central entender que o lógico polonês acreditava que nenhum termo semântico precisaria ser tomado como primitivo, não definido, e que tais termos podem receber definições não circulares.
} 
às propriedades nas línguas naturais que bloqueiam a aplicação consistente do conceito de verdade para elas. Antes, no entanto, de examinar essa objeção, abordemos a questão de como Tarski descreve o seu que projeto de uma definição de verdade e à qual concepção de verdade ele acredita que método deve se conformar.

\subsection{Capturando o conceito intuitivo de verdade.}

Quer em "The Semantic Concept of Truth in Formalized Languages" 32 - trabalho em que Tarski expõe pela primeira vez sua definição, e onde todo o percurso formal e técnico de construção da definição de verdade é apresentado - quer nos artigos não técnicos de divulgação e respostas a abjeções e polêmicas, fundamentalmente em "The Semantic Conception of Truth and the Foundations of Semantics" 33 e "Truth and Proof" ${ }^{34}$, Tarski descreve o objetivo do seu método como uma tentativa de "capturar o significado real de uma noção antiga" (Tarski 1944: 341), "seu significado intuitivo e intenção geral” (Tarski 1983[1933/1956]: 155) ${ }^{35}$. Mas que noção antiga e significado intuitivo Tarski tem em perspectiva? Trata-se especificamente da noção que se convencionou chamar na literatura de 'concepção clássica de verdade’. Tal concepção, na interpretação de Tarski, encontraria sua expressão de forma bastante precisa na definição aristotélica de verdade:

Dizer do que é que ele não é, ou do que não é que ele é, é falso, enquanto dizer do que é que ele é, e do que não é que ele não é, é verdadeiro. ${ }^{36}$

\footnotetext{
${ }^{32}$ Segundo Tarski, em nota no início da monografia, grande parte do conteúdo deste trabalho é divulgada pela primeira vez em 1929. Ela é discutido em duas comunicação de Tarski na seção de lógica na Sociedade Filosófica de Varsóvia, em 8 de outubro de 1930, e na Sociedade Filosófica Polonesa, em 5 de dezembro do mesmo ano. A primeira versão da monografia aparece em polonês, em 1933. Em seguida foi traduzida para diversas línguas: Alemão (1935), Inglês (1956), Italiano (1961), Francês (1972), etc. Sempre que citarmos aqui passagens da monografia usaremos as datas 1933 e 1956 para se referir, respectivamente, a sua primeira publicação, que ocorre em Polonês, e a sua primeira tradução para o Inglês.

${ }^{33}$ In Philosophy and Phenomenological Research, volume 4, 1944, 341-76.

${ }_{34}^{34}$ In Scientific American, 220, (6), 1969, 63-77.

${ }^{35}$ Tarski indica mais de uma vez nos textos mencionados que sua definição teria um caráter de explicação descritiva, no sentido de capturar o conceito intuitivo sujacente ao uso do termo „x é verdadeiro“ em uma linguagem. Contudo, em "Truth and Proof" (1969), ele aventa, tendo em vista uma viável leitura acerca do seu projeto, a possibilidade de sua definição não ser avaliada do ponto de vista da sua correção, mas da sua utilidade, e que ela poderia ser interpretada

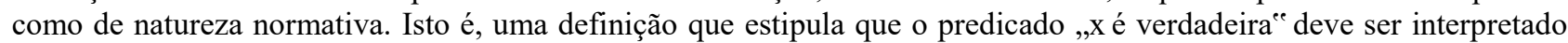
de determinada forma. Contudo, ainda que contemplando essa possibilidade, e dando a ela o merecido crédito, ainda assim Tarski continua mantendo que, mesmo que sua definição se revele de caráter mais prescritivo do que descritivo, ele acredita que ela esteja mais próxima do que outras definições do significado do termo no discurso ordinário. Para a tese de que a definição semântica de Tarski não capturaria nada sobre o conceito intuitivo de verdade, que ela apenas estipula verdade para uma linguagem, e que, por isso, deve ser lida como uma definição estipulativa, ver Etchemendy, J. "Tarski on Truth and Logical Consequence". The Jornal of Symbolic Logic, LIII, 1988: 51-79; Soames, S. "What is a Theory of Truth". The journal of Philosophy, LXXXI, 8, 1984: 411-429.

${ }^{36}$ Metafisica $\Gamma 1011 \mathrm{~b} 25$.
} 
Nos trabalhos mencionados de Tarski, uma teoria baseada na noção clássica é uma teoria regulada pela concepção correspondencialista de verdade, subjacente no uso cotidiano que fazemos de expressões como ,tal-e-tal é verdadeiro“e, „é verdade que tal-e-tal’, etc. Sob essa descrição, trata-se de uma noção que concebe verdade como alguma forma de correspondência com o mundo, a realidade.

Mencionaria apenas que, ao longo de todo este trabalho, ocuparei-me exclusivamente em apreender as intenções contidas na assim chamada concepção clássica de verdade (,verdadeiro ${ }^{e e}$ - correspondente à realidade). (Tarski 1983 [1933/1956]: 153).

O conteúdo intuitivo presente na definição de Aristóteles parece bastante claro: digo algo verdadeiro quando o que digo que é realmente é, quando digo que algo é o caso e algo realmente é o caso, e quando digo do que não é o caso que ele não é o caso. Tarski observa que a formulação aristotélica tem a vantagem de tomar verdade como uma relação entre enunciados de sentenças e o mundo ou fragmentos do mundo - dado o uso do verbo „dizer ${ }^{\text {ee }}$ não recorrendo a noções mais obscuras, como ideias, pensamentos, proposições. Na definição de Aristóteles, os portadores de verdade - para usar uma terminologia contemporânea - seriam, argumenta Tarski, entidades linguísticas. O lógico polonês exportará a mesma postura para sua concepção, em que, como mostrarei, as entidades na extensão do predicado de verdade serão sentenças de uma linguagem. A formulação aristotélica, ainda seria deficitáriam, entende Tarski, basicamente pelo fato de ela não possuir a generalidade requerida de uma definição de verdade. Isso porque rla "se refere apenas a sentenças que „dizem' de algo que „ele éce ou que „ele não éecc، (Tarski 1969: 63). Limitação essa que sugere que tentar colocar todas as sentenças no formato que a definição demanda, parece "dificilmente possível [...] sem enviesar o sentido da sentença e forçar o espírito da linguagem" (idem) sob investigação.

Tarski examina também tentativas de definições e versões correspondencionalistas mais contemporâneas e que também são exibidas como em acordo com a concepção clássica de verdade; em especial, as seguintes:

i). Uma sentença verdadeira é aquela que diz de um estado-de-coisas que ele é tal-etal, e o estado-de-coisas é tal-e-tal.

ii). Uma sentença é verdadeira se ela designa/denota um estado-de-coisas existente (um fato). 
iii). A verdade de uma sentença é sua conformidade (ou correspondência) com a realidade. ${ }^{37}$

Embora tais fórmulas estejam, em termos gerais, em concordância com o espírito da concepção clássica, uma vez que adotam uma posição correpondencionalista, o sentimento é de que, se as analisarmos de mais perto, perceberemos que elas são mais vagas, imprecisas e ambíguas do que a definição aristotélica. Esses termos técnicos do campo filosófico, como estado-de-coisas, correspondência, conformidade, fato, demandam definições prévias claras que elucidem sem ambiguidade seu significado e tornem sua aplicação precisa. De imediato aparece uma série de perguntas intrigantes que as próprias definições (i-iii) motivam. Qual o significado do termo “corresponder"? Que condições garantem a conformidade de uma sentença com um estado-decoisas? Quais são as condições de individuação de um estado-de-coisas? O que uma sentença compartilharia com um estado-de-coisas que garante que o que ela diz do estado-de-coisas descreve propriedades constituintes do mesmo? Os termos ,designar' e 'denotar', originalmente aplicados somente a nomes com referentes precisos, possuem o mesmo significado quando aplicados a sentenças? Nomear um estado-de-coisas é o mesmo que nomear um objeto, uma pessoa? Se as sentenças designam estado-de-coisas, então elas são seus nomes? O que significa tomar uma sentença como um nome? A postulação de fatos e estados-de coisas é indispensável em uma teoria semântica correspondencionalista da verdade? ${ }^{38}$

Em virtude da insuficiência de precisão dessas definições (e a enxurrada de interrogações que suscitam), as quais operam com conceitos que requerem também definições mais rigorosas, e que talvez sequer venham a receber caracterizações convincentes, imunes a objeções robustas, (i)(iii) são fontes de incompreensões que, muitas das vezes, levam a debates estéreis sobre a natureza desses conceitos. Haja vista os resultados pouco consensuais e frutíferos extraídos desses debates, à revelia do amplo debate na literatura sobre estados-de-coisas, fatos e a correspondência entre esses "fragmentos" do mundo e entidades tomadas como portadorzs de verdade (crenças, proposições, sentenças, enunciados, atos de fala, etc)

Imbuído da maioria das reticências e perguntas suscitadas por uma observação mais atenta das fórmulas (i)-(iii), Tarski defende a tese de que

todas essas formulações podem levar a diversas incompreensões, pois nenhuma delas é suficientemente precisa e clara (embora isso se aplique bem menos à formulação aristotélica original do que às outras); de qualquer forma, nenhuma delas pode ser

\footnotetext{
${ }^{37}$ Para uma exposição crítica dessas definições, ver Kirkham, R. L. Theories of Truth: a critical Introduction. The MIT Press, Cambridge, Massachesetts, 1997; em especial o capítulo 4.

${ }^{38}$ Ver capítulo I para temas relacionados a essas perguntas.
} 
considerada uma definição satisfatória de verdade. Cabe a nós procurar por uma expressão mais precisa de nossas intuições. (Tarski 1944: 343).

Ao pé da letra, a mensagem de Tarski é que, desde Aristóteles, não houve progresso algum quanto à introdução de uma definição de verdade, em concordância com o espírito do conceito intuitivo de verdade usado na vida diária, mas, por assim dizer, purgada das imprecisões, vaguezas e inconsistências do uso intuitivo deste conceito e que são fontes de muitos equívocos sobre a sua natureza. Em verdade, pode-se falar até em retrocesso, pois Tarski considera a definição aristotélica mais precisa e clara do que versões correspondecionalistas contemporâneas ${ }^{39}$. Na leitura de Tarski, sua estratégia inclusive não consiste em descartar a definição aristolélica, mas em "suplantar a formulação aristotélica enquanto preserva suas intenções basicas” (Tarski, 1969: 64), seu espírito, recorrendo, para isso, a "algumas técnicas da lógica contemporânea” (idem).

Para introduzir a sua proposta, Tarski nos convida a considerar uma sentença de uma linguagem natural cujo significado não levanta dúvidas e, portanto, não é fonte de debate. Sendo fiel ao clássico exemplo do autor, ilustremos um caso como este com a sentença do português ,,a neve é branca ${ }^{e e}$. Por questão de abreviação, designemos esta sentença pela letra $s$, no sentido de que $s$ opera aqui como uma abreviação de ,a neve é branca“e. Tarski nos provoca

O que significamos quando dizemos que $s$ é verdadeira ou $s$ é falsa? A resposta a essa pergunta é simples: no espírito da explicação aristotélica, dizer que $s$ é verdadeira significa simplesmente dizer que a neve é branca, e dizer que s é falsa significa dizer que a neve não é branca (Tarski 1969: 64).

Esta constatação, à primeira vista trivial, apresenta um elemento bastante importante: dizer da sentença ,a neve é branca ${ }^{e e}$ que ela é verdadeira quando a neve é branca, sugere que estamos aqui asseverando as condições de verdade da sentença, i.e., as condições no mundo que garantem a verdade de ,a neve é branca ${ }^{e}$. Sob este prisma, a verdade de uma sentença declarativa dependeria, então, do que ela diz ocorrer no mundo ocorrer mesmo no mundo. Com isso em mente, a verdade e falsidade de $s$ pode ser formulada introduzindo a equivalência lógica, recurso empregado em definições:

iv). ,a neve é branca é verdadeira $\leftrightarrow$ a neve é branca.

v). „a neve é brancaeé falsa $\leftrightarrow$ a neve não é branca. ${ }^{40}$

\footnotetext{
${ }^{39}$ Para posição semelhante, ver Davidson, D. "The Folly of Trying to Define Truth”, in Truth, Language, and History. Oxford University Press, 2009.

${ }^{40}$ Daqui em diante empregarei „↔“"como símbolo de equivalência material. Ele deve ser lido como ,se, e somente se“
} 
Como pode ser notado, as sentenças (iv) e (v) podem ser interpretadas como definições da verdade e falsidade da sentença "a neve é branca". Elas são conformadas de duas partes. Do lado esquerdo do bicondicional temos o definiendum, i.e., a expressão a ser definida, e do lado direito tem-se o definiens, i.e., a expressão definidora. No definiens explica-se o significado da expressão que ocupa a posição de definiendum. Nesse sentido, em (iv) e (v) o definiendum são as sentenças "a neve é branca"e é verdadeira"e e "a neve é branca"é falsa". Os termos „verdadeiro ${ }^{e e}$ e „falso ${ }^{\text {ee }}$ são aqui tomados como predicados de sentenças, e estão predicando a verdade e falsidade de ,a neve é branca $^{e e}$. Logo, ,a neve é branca ${ }^{e e}$ ocorre como sujeito das sentenças. O que significa que sua posição é a de um nome na predicação. As aspas indicam que „a neve é brancae é o nome da sentença. De maneira que (iv) e (v) dão as condições para que a sentença referida pelo seu nome esteja na

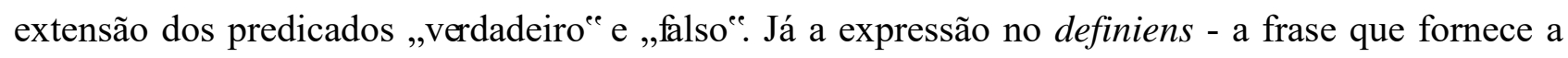
explicação - é a própria sentença referida no definiendum pelo seu nome. No lado direito eliminamse as aspas e os termos semânticos ,,verdadeiro ${ }^{\text {ee }}$ e „falso ${ }^{\text {ee }}$, e ficamos apenas com a própria sentença ou uma tradução dela.

O que temos em (iv) e (v) são, então, nas palavras de Tarski, definições parciais de verdade, pois apresentam condições de falsidade e verdade de uma sentença particular. As definições acima exibem uma estrutura que, na estratégia tarskiana, pode ser generalizada para outras sentenças, na medida em que se pretende para essas novas sentenças apresentar suas condições de verdade numa fórmula de definição como (iv) e (v). Cada definição parcial teria, assim, a seguinte estrutura geral

\section{1. , „Se é verdadeira em $\mathrm{L} \leftrightarrow p$}

onde do lado direito da equivalência tem-se uma variável entre aspas - que pode ser substituída pelo nome de uma sentença qualquer - e o predicado de verdade (que é uma unidade sintática do definiendum), e, do lado direito, a variável a ser ocupada pela própria sentença (ou uma tradução dela) que é nomeada do lado esquerdo. O modelo (1), chamado por Tarski de esquema-T, não é a definição de verdade, mas tão somente um esquema que ilustra a estrutura do que mais à frente será cunhado de sentenças-T, i.e., sentenças que instanciam (1). A definição de verdade de Tarski só será introduzida depois de se definir o conceito de satisfação, uma vez que verdade será definida em termos deste conceito. Como será investigado mais à frente neste capítulo, sentenças-T como (iv) e (v) deverão ser consequências lógicas de uma definição adequada de verdade.

Bom, agora estamos em posse de definições parciais de verdade que, segundo Tarski, captam o espírito da concepção clássica, e de um esquema geral que explicita a estrutura dessas definições. Com isso, estamos em condições de olhar para as línguas naturais e elucidar como que 
Tarski intentou demonstrar que qualquer método que instancia o esquema- $T$ com as sentenças de uma língua natural é inviável, e não em razão do método, mas da própria das línguas naturais. O uso adequado do termo predicativo ,verdadeiro ce para uma língua natural não será assegurado pelo método do esquema- $T$, pois inevitavelmente seremos levados a engendram contradições formais, em especial a antinomia do mentiroso.

\section{A antinomia do mentiroso e as línguas naturais.}

Muitas são as versões da antinomia do mentiroso, mas elaborarei a seguir uma bastante semelhante à versão apresentada em mais de uma oportunidade por Tarski e exibida pela primeira vez na seção 1 de "The Concept of Truth in Formalized Languages" 41 . Vejamos.

Primeiramente, tomemos o símbolo ,ce como abreviando a descrição definida ,a sentença numerada 2 nesta página ${ }^{e}$. Consideremos, então, a seguinte sentença:

2. c não é uma sentença verdadeira.

Sendo „ce uma abreviação de ,a sentença numerada 2 nesta página ${ }^{e e}$, podemos constatar empiricamente que

3. „c não é uma sentença verdadeira ${ }^{e e}$ idêntica a c.

pois „, não é uma sentença verdadeira ${ }^{e e ~ „, c e ~ s e ~ r e f e r e m ~ o u ~ d e s c r e v e m ~ a ~ m e s m a ~ s e n t e n c ̧ a, ~ a ~ s a b e r, ~}$ (2). A sentença-T de (2) é

4. „c não é uma sentença verdadeira ${ }^{e e}$ uma sentença verdadeira $\leftrightarrow$ c não é uma sentença verdadeira.

onde do lado direito da equivalência removo as aspas e escrevo a própria sentença. Por essa razão, tendo (3) e (4) como premissas, e pelo princípio de substitutividade que pode ser aplicado em

\footnotetext{
${ }^{41}$ Mas foi Leśniewski quem primeiro demonstrou que as linguagens naturais engendram contradições, que são infectadas com antinomias, e que por isso apresentam resultados negativos quanto à viabilidade de se aplicar consistentemente uma definição de verdade a elas. Segundo o próprio Tarski, essa perspectiva "foi desenvolvida por Leśniewski em suas palestras na universidade de Varsóvia (no ano acadêmico de 1919/20 em diante), em discussões científicas e em conversas privadas. Isso se aplica, em particular, a quase tudo que direi sobre expressões entre marcas de citação e as antinomias semânticas "(Tarski 1983[1956]: 155; nota 1). Para uma recuperação histórica do tratamento desenvolvido por Leśniewski para o paradoxo do mentiroso ver Betti (2004).
} 
função do enunciado de identidade (3), podemos substituir ,c não é uma sentença verdadeira ${ }^{e e}$ por „,ce, e teremos, como consequência, a seguinte contradição:

5. c é uma sentença verdadeira $\leftrightarrow$ c não é uma sentença verdadeira. ${ }^{42}$

Notem que (2)-(5) são todas sentenças, a princípio, bem formadas da Língua Portuguesa. São sentenças cujo significado pode ser apreendido, ainda que possa exigir um esforço lógico, por qualquer falante fluente do Português. Contudo, a gramaticalidade dessas sentenças possibilitou que gerássemos (5), que é claramente uma contradição lógica e viola, portanto, o princípio de nãocontradição. Mas quais são as fontes desta contradição? Que propriedades estas sentenças apresentaram que permitiu que engendrassem esta antinomia? Não contente meramente em exemplificar diferentes contextos nas línguas naturais em que o paradoxo do mentiroso é gerado, Tarski oferece um diagnóstico robusto de por que a linguagem ordinária origina essa antinomia, e, portanto, porque uma definição de verdade para a língua natural não é, na sua terminologia, materialmente adequada.

Tarski identifica a fonte da antinomia no fato de as línguas naturais serem o que ele chama de “universais". A linguagem ordinária é universal porque ela contém em potencial a capacidade de expressar tudo o que pode ser expresso em qualquer linguagem, em contraste com as linguagens formalizadas, cujo poder expressivo pode ser demarcado. Como uma lingua natural está sempre em expansão, ela não somente é formada pelos objetos linguísticos que a constituem (sílabas, expressões, palavras, sentenças, etc), mas também possui meios de se referir a essas mesmas sílabas, expressões, palavras, sentenças, etc. Argumenta Tarski em “The Concept of Truth in Formalized Languages":

Uma característica da linguagem coloquial (em contraste com diversas linguagens científicas) é sua universalidade. Não estaria em harmonia com o espírito desta linguagem se em outra linguagem ocorresse uma palavra que não pudesse ser

\footnotetext{
${ }^{42} \mathrm{O}$ primeiro aparecimento do paradoxo do mentiroso é atribuído à Grécia Antiga. A versão grega aparece da seguinte forma: supostamente um cretense de nome Epimênides teria certa vez dito que todos o cretenses são sempre mentirosos. A consequência do enunciado de Epimênides é que, se um mentiroso diz sempre a mentira, então se o enunciado de Epimênides é verdadeiro, então ele é falso. Já a versão mais recorrente envolve uma sentença auto-referencial, que fala de si mesma que ela é falsa. A sentença tem a forma

(S) esta sentença é falsa.

Suponha, agora, que (S) é verdadeira; então o que ela diz é o caso; logo, se o que ela diz é o caso, então ela é falsa. Por outro lado, suponha que ela seja falsa, então o que ela diz não é o caso. Logo (S) é verdadeira. Do que se deduz a contradição: (S) é verdadeira se, e somente se, (S) é falsa. Para a ilustração de mais versões da antinomia do mentiroso, ver Haack (1978), capítulo 8.
} 
traduzida nela. Poderia ser afirmado que ,se podemos falar de forma significativa sobre qualquer coisa, podemos também falar sobre isso na linguagem coloquiale. Se mantivermos tal universalidade da linguagem cotidiana em conexão com investigações semânticas, devemos, para sermos consistentes, adimitir nesta linguagem, além de suas sentenças, também os nomes dessas sentenças e expressões, e sentenças contendo esses nomes, assim como expressões do tipo ,sentença verdadeira"e, ,nome", ,denota"e, etc. Mas é presumivelmente essa universalidade da linguagem cotidiana que é a fonte primária de todas as antinomias semânticas, como as antinomias do mentiroso [...]. Essas antinomias parecem fornecer uma prova de que toda linguagem que é universal no sentido acima, e na qual as leis normais da lógica valem, deve ser inconsistente (Tarski 1983[1933/1956]: 164-165).

E retoma em "The Semantic Conception of Truth and the Foundations of Semantics":

\begin{abstract}
Assumimos [...] que a linguagem na qual a antinomia é construída contém, além das suas expressões, também nomes dessas expressões, assim como termos semânticos como o termo "verdadeiro" se referindo a sentenças dessa linguagem; também assumimos que todas as sentenças que determinam o uso adequado desse termo podem ser asseridas na linguagem. Uma linguagem com essas propriedades será chamada de "semanticamente fechada". (Tarski 1944: 348)
\end{abstract}

Na linguagem natural pode-se criar nomes de nomes, nomes de sentenças, nomes de sentenças no interior de sentenças (em especial pelo mecanismo de colocar expressões em citação, tal como quando digo ,a palavra “portuguesa” é uma expressão da Língua Portuguesa"), e assim por diante. Mas a linguagem natural não para por aí. Todos os termos semânticos que podem ocorrer em uma

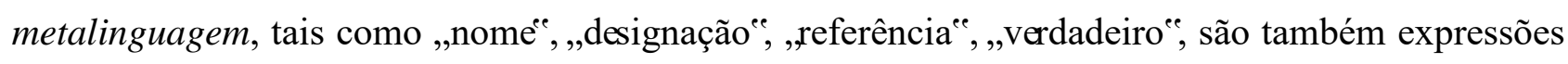
de uma linguagem natural.

Notem, portanto, que a antinomia do mentiroso é gerada pela conjugação do mecanismo na linguagem ordinária de nomear suas próprias sentenças, com o emprego do predicado „verdadeiro“e, que também seria uma expressão da linguagem coloquial. Assumindo que o termo ,verdadeiro ${ }^{c e} \mathrm{em}$ língua natural opera como um predicado de sentenças, em princípio, é possível gerar na linguagem ordinária sentenças em que a expressão predicativa „,verdadeiro“ toma como argumento um termo que se refere a uma sentença que também contém o predicado „verdadeiro ${ }^{\circledR}$. Isso é facilmente exibido em sentenças como
6. „a grama é verde é verdadeiraee é verdadeira.
$6^{\text {ee }}$, ,a grama é verde é falsa é verdadeira.

que, ainda que incomuns, pois não vemos pessoas no dia-a-dia produzindo sentenças como (6) e $\left(6^{\bullet}\right)$, são completamente possíveis de serem construídas. Observem que nelas a expressão entre aspas se refere a uma sentença da qual já foi predicado verdade falsidade, e a segunda ocorrência 
do predicado possui na sua extensão sentenças nas quais o próprio predicado é empregado. É essencialmente esse recurso expressivo que gera a antinomia do mentiroso, e expõe a inconsistência das línguas naturais, segundo Tasrki.

Tarski diagnostica, então, a origem imediata do paradoxo do mentiroso nas línguas naturais justamente em função de elas (i) possuírem os meios de se referir às suas próprias expressões e do fato (ii) de as expressões ,,verdadeiro ${ }^{\text {ee }}$,fallso ${ }^{\text {ee }}$, assim como outros termos semânticos, poderem aparecer nelas, em vários contextos, como predicados de suas próprias sentenças. Tarski convencionou chamar linguagens com as características (i) e (ii) de "semanticamente fechadas". Essas linguagens engendrariam contradições formais, então, em virtude de serem autorreferentes e possuirem predicados de verdade; em suma, de conterem suas próprias metalinguagens. Como pontua Kirkham, "uma linguagem semanticamente fechada é aquela que tem o poder de descrever as características semânticas de seus próprios elementos” (Kirkham 1997: 161). Em outros termos, linguagens "semanticamente fechadas" possuem a propriedade de poderem falar de si mesmas, de terem a si mesmas como objeto de descrição e referência. Sendo essa capacidade expressiva a fonte da sua inconsistência, e da impossibilidade de definir ' $x$ é verdadeira em $L$ ' (onde $L$ é uma língua natural) para linguagens com capacidade autorreferencial.

A análise da antinomia do mentiroso nas línguas naturais está, em vista do exposto acima, na base do projeto semântico de Tarski. É a partir da investigação de como o paradoxo pode ser construído e reconstruído na linguagem ordinária que Tarski acredita que essa antinomia pode "fornecer uma prova de que toda linguagem que é universal [...] e na qual as leis normais da lógica valem, deve ser inconsistente" (Tarski 1983[1933/1956]: 164-165). Já de antemão avesso a abandonar as leis da lógica clássica - especificamente o princípio de não-contradição - e tendo por referência negativa o comportamento da linguagem ordinária, apresentando-a como ilustração do fracasso de se perseguir uma teoria semântica da verdade para linguagens semanticamente fechadas, Tarski empreende, então, o projeto de estabelecer o uso adequado da expressão ,x é verdadeiro"e para uma linguagem $\mathrm{L}$ e de determinar as propriedades essenciais que L deve possuir e o que ela não pode conter para impedir que nela o paradoxos semânticos sejam reconstruídos.

\section{Linguagens formalizadas e a Convenção- $T$.}

O critério regulador de uma definição adequada de verdade proposta por Tarski (que é chamado ora de critério de adequação material, ora de Convenção-T), estipula que uma definição de verdade é dita adequada (leia-se: em conformidade com a concepção clássica de verdade), se tiver como consequência lógica todas as equivalências da forma (1), aqui repetida como (7) 


\section{7. ,peé verdadeira em $\mathrm{L} \leftrightarrow p$}

para todas as sentenças da linguagem sob investigação, em que ,,pe, ,no lado do definiendum) é substituída por uma descrição estrutural de uma sentença de L e $p$ (no lado do definiens) é substituída pela própria sentença - caso a metalinguagem contenha a linguagem objeto - ou por uma tradução da sentença referida pela descrição. Uma teoria da verdade para uma linguagem L é, portanto, materialmente adequada, se, e somente se, ela instancia o esquema-T (1) como teorema para toda sentença de L. Uma instanciação de (1) para uma dada sentença $p$ de L (que será uma definição parcial de verdade, como já dito acima, pois é uma definição de verdade para $p$ ) é chamada de a sentença-T de p.

O esquema (1), assim como a descrição estrutural e a tradução de uma sentença da linguagem objeto, são todas sentenças de uma metalinguagem. A distinção rígida entre metalinguagem e linguagem objeto será crucial para a estratégia tarskiana. Se a fonte do paradoxo em linguagens semanticamente fechadas decorre de elas conterem termos semânticos e mecanismos de autorreferência, uma definição de verdade materialmente adequada ocorrerá estabelecendo uma distinção entre duas linguagens. A linguagem sobre a qual se fala, ou seja, a linguagem para a qual se quer definir verdade, chamada por Tarski de linguagem objeto, e linguagem na qual se fala sobre a linguagem objeto, a saber, a metalinguagem. ${ }^{43}$ Nesse sentido, com um exame atento das propriedades que geram a inconsistência das linguagens semanticamente fechadas é fácil entrever uma prescrição dada por Tarski: sua definição só se aplica a linguagens que não possuem termos semânticos, em especial os predicados de verdade, tampouco meios de se referir a suas próprias expressões. Logo, o predicado „verdadeira em L“e de (1) é uma expressão da ML, e será definida na ML. E a sentença que substitui $p$ não conterá ela própria o predicado „é verdadeiro“

Após o diagnóstico acima investigado, Tarski conclui, na sua monografia:

[...] Se essas observações estão corretas, então toda possibilidade de um uso consistente da expressão, ,sentença verdadeira ${ }^{e e}$ em harmonia com as leis da lógica e o espírito da linguagem cotidiana parece ser bastante questionável, e, consequentemente, a mesma dúvida ocorre com respeito à possibilidade de construir uma definição correta dessa expressão. (Tarski 1983[1933/1956]: 165).

$\mathrm{Na}$ medida em que uma linguagem semanticamente fechada predica verdade de suas próprias sentenças e nomeia essas sentenças predicadas, não se pode consistentemente erigir uma teoria da verdade para ela. A solução de Tarski - reiterando - consistirá, diagnosticado isso, em abrir mão de

\footnotetext{
${ }^{43}$ De agora em diante abreviaremos o termo „metalinguagem' por ML, e a expressão ,linguagem objeto ${ }^{\text {ce }}$ por LO.
} 
um projeto mais geral de definir ,X é verdadeira em L“e, L incluindo as línguas naturais (já que não está disposto a pôr de lado as leis da lógica), e circunscrevê-lo apenas a linguagens formalizadas.

Linguagens formalizadas, no sentido caracterizado em "The Concept of Truth in Formalized Languages”, consiste em linguagens cuja estrutura é rigorosamente especificada. Tal especificação exige que determinemos precisamente a classe das expressões que são consideradas significativas. As propriedades essências que uma linguagem formalizada deve possuir são as seguintes:

( $\alpha$ ) para cada uma dessas linguagens uma lista ou descrição é dada em termos estruturais de todos os sinais com os quais as expressões da linguagem são formadas; $(\beta)$ entre todas as possíveis expressões que podem ser formadas com esses sinais aquelas chamadas sentenças são distinguidas por meio de propriedades puramente estruturais (Tarski 1983[1933/1956] 1969: 166).

É preciso uma lista das expressões constitutivas da linguagem (seu alfabeto, vocabulário), e definições que garantem a identificação das expressões e quando uma expressão é considerada uma sentença. Estas devem ser distinguidas das expressões não sentencias por propriedades estruturais explicitadas na sua definição. Essas propriedades estruturais distintivas das expressões denominadas sentenças operam como regras de reconhecimento. Uma vez presentes na expressão, asseguram sua sentencidade (sentencehood). ${ }^{44}$

Para a construção do conceito de verdade de Tarski, um método preciso de identificação da sentencidade de uma expressão será fundamental, pois a estratégia é de explicar o que é uma sentença verdadeira em uma dada linguagem fixada. A pergunta que Tarski persegue é: o que significa dizer que uma dada sentença de uma linguagem é verdadeira, que ' $x$ é verdadeira em $L$ '? O intuito é de, uma vez correta a definição de verdade para um linguagem, ter na extensão do predicado ,verdadeira em $\mathrm{L}^{\mathrm{e}}$ somente entidades sentenciais verdadeiras. Para tal, tem-se que ter em mãos um método de circunscrição da classe das sentenças de uma linguagem fixada para investigação. ${ }^{45}$ Isso posto, podemos agora nos debruçar sobre o processo de descrição da linguagem objeto de Tarski, a linguagem do cálculo das classes, e sobre o método de construção da ML onde

\footnotetext{
${ }^{44}$ Como ficará evidenciado à medida que progredirmos nas etapas de construção da definição de verdade, Tarski a atinge mediante uma série de passos essenciais. Em primeiro lugar se define o que é uma sentença de uma linguagem particular. Em segundo lugar, a relação de satisfação é caracterizada recursivamente, com uma definição de satisfação sendo fornecida. Por último, difine-se verdade para uma linguagem com base nos conceitos de sentença e satisfação.

${ }^{45}$ Contudo, como as linguagens sob tratamento nos trabalhos de Tarski são linguagens das ciências dedutivas, em especial a linguagem do cálculo das classes - para a qual se constrói na sua monografia uma definição de verdade - duas mais propriedades são acrescentadas: $(\delta)$ lista ou descrição estrutural das sentenças ditas axiomas e $(\gamma)$ regras de inferência, ou seja, regras para gerar sentenças a partir de sentenças. Embora Tarski esteja fundamentalmente interessado em linguagens formalizadas de sistemas dedutivos, a não especificação de $(\delta)$ e $(\gamma)$ para uma linguagem sob investigação não exclui a possibilidade do uso consistente do predicado de verdade para ela. As propriedades suficientes pra se dizer se uma linguagem é formalizada ou não são $(\alpha)$ e $(\beta)$. Se consigo, na especificação da estrutura de uma linguagem, referir-me tão somente à forma das suas expressões, então a linguagem é formalizada.
} 
será defina verdade para a LO. Mas antes, devemos examinar o elemento nuclear da definição de Tarski, que é a Convenção-T ou adequação material. Isso porque a condição imposta por Tarski para assegurar uma definição satisfatória de verdade para uma linguagem dada é em essência a Convenção-T. É ela o teste de adequação de uma definição semântica de verdade, i.e., de uma definição em concordância com a concepção clássica e imune a antinomias.

Tarski expressa a Convenção-T da seguinte maneira:

Uma definição formalmente correta do símbolo „Trre, formulada na metalinguagem, será chamada de uma definição adequada de verdade se ela tiver as seguintes consequências:

$(\alpha)$ todas as sentenças que são obtidas a partir da expressão „,x $\in \operatorname{Tr}$ se e somente se $\mathrm{p}^{\text {ee }}$ substituindo o símbolo ,X" $\mathrm{X}$ por um nome descritivo-estrutural de qualquer sentença da linguagem em questão e o símbolo ,pe pela expressão que forma a tradução desta sentença na metalinguagem;

$(\beta)$ a sentença ,para qualquer $\mathrm{x}$, se $\mathrm{x} \in \operatorname{Tr}$ então $\mathrm{x} \in \mathrm{S}^{\text {ee }}$ (em outras palavras „Tr $\subseteq$ $\left.\mathrm{S}^{\mathrm{ee}}\right)$.(Tarski 1983[1933/1956]: 187-188).

A Convenção- $T$ estipula, em sua cláusula $(\alpha)$, que toda definição de verdade deve ter, para cada sentença da LO investigada, como consequência uma sentença-T - i.e., da forma ' 's' é verdadeira se e somente $p$ ' - onde , „se é substituída por uma descrição estrutural de uma sentença qualquer da linguagem e $p$ pela própria sentença, caso a ML contenha a LO, ou uma tradução da sentença. Entende-se aqui por nome descritivo-estrutural de uma sentença um nome que descreve a sentença como uma concatenação estruturada de elementos. Uma descrição estrutural pode se dar no nível das palavras, como também no nível das sílabas que se concatenam na configuração de uma sentença (ou até mesmo dos fonemas). A necessidade de um nome descritivo-estrutural, em vez de meramente um nome de uma sentença que a apresenta como uma unidade não estruturada decorre do fato de que o propósito de Tarski, como será elucidado detalhadamente mais à frente, é de especificar as condições de verdade das sentenças de uma linguagem com base na sua estrutura e na contribuição de suas unidades constituintes para a geração das suas condições de verdade. Já a cláusula $(\beta)$ estabelece que sob a extensão do predicado de verdade só podem cair expressões que são sentenças. Do que se infere que as sentenças verdadeiras são um subconjunto das sentenças de LO.

Há duas características importantes da Convenção- $T$ para as quais é imperativo chamar a atenção aqui, pois, sem atentar a elas, corre-se o risco de uma incompreensão da relação entre verdade e significado na definição de Tarski, e, por consequência, de como Davidson reinterpreta e reorienta esta relação no contexto de conformação de uma teoria do significado para as línguas naturais. Em primeiro lugar, a cláusula $(\alpha)$ estabelece que, para a adequação de uma definição de verdade, as sentenças que ocorrem no lado direito das equivalências das sentenças- $T$ sejam 
traduções na ML das sentenças da LO, i.e., interpretações das sentenças de LO. Nesse sentido, a Convenção-T apela a uma compreensão prévia da noção de tradução, que Tarski não procure definir, para determinar se uma definição dada de verdade é adequada. Do que se depreende que, embora a preocupação de Tarski seja de fornecer uma definição de verdade, e não de conceitos tais como significado, sinônímia e tradução, este último cumpre um papel indispensável no estabelecimento do critério geral de adequação de uma teoria da verdade. Isso porque uma teoria na qual a ML não contém a LO, mas que não fornece traduções das sentenças de LO, necessariamente viola a Convenção-T.

Em segundo lugar, um exame atento da clausula $(\alpha)$ evidencia que ela ainda aponta para mais um papel decisivo que a noção de tradução cumpre na Covenção-T, se aceitarmos, seguindo Tarski, que uma definição materialmente adequada capturaria o conceito intuitivo de verdade. $\mathrm{Na}$ perspectiva de Tarski, o que asseguraria em alguma medida a conformação de uma definição com o conceito intuitivo de verdade é o fato de que um predicado de verdade em uma definição que acarreta uma sentença-T para cada sentença de uma LO - se a definição respeitar a Convenção- $T$ possui necessariamente na sua extensão somente a classe das sentenças verdadeiras de LO. Isso porque um aspecto constitutivo da noção intuitiva de verdade parece ser jutamente a ideia de que um predicado de verdade se aplica somente a sentenças verdadeiras.

Assim, uma vez que a Convenção- $T$ capturaria essa ideia, ao menos alguma propriedade importante do conceito geral e pré-teórico de verdade seria iluminada pela Convenção- $T$, ainda que uma definição formal de verdade seja sempre relativa a uma linguagem. Guiados por esse argumento, é fácil perceber que o apelo explícito à noção de tradução na Convenção-T sugere que deve haver uma conexão importante entre o conceito de verdade para uma língua particular e significado, em especial quando se quer falar em uma linguagem sobre a verdade das sentenças de outra linguagem. Essa conexão, no entanto, não é examinada nos trabalhos de Tarski. E uma razão para isso, mais determinante do que o fato de a preocupação central ser a de definir verdade, é que Tarski fornece sua definição para linguagens formais já interpretadas, sendo suficiente, nesses casos, associar a cada expressão da LO uma expressão da ML que se convenciona tratar como sendo sua tradução. Talvez por isso, num primeiro momento, a estratégia de tomar como certo uma compreensão prévia da noção de tradução pode aparentemente ter o efeito de diminuir a centralidade deste conceito. Mas um escrutínio atento da clásula $(\alpha)$ da Convenção- $T$ evidencia como que o conceito de tradução, sob a lente de Tarski, opera de forma decisiva, em particular 
quando a ML não contém a LO, na ponte entre uma definição de verdade adequada e o conceito ordinário de verdade. ${ }^{46} 47$

Por causa da centralidade na estratégia de Tarski da distição entre duas linguagens - LO e ML - é preciso que olhemos para elas agora e investiguemos as propriedades essências e recursos lógicos necessários à ML que Tarski constrói para interpretar a linguagem do cálculo das classes. Como ficará evidenciado, a estrutura da ML, em parte, reflete a estrutura da linguagem sobre a qual ela fala.

\subsection{Descrição da linguagem objeto}

A linguagem objeto para a qual Tarski constrói sua definição formal de verdade é relativamente simples: ela contém apenas quatro constantes lógicas - a saber, símbolos para inclusão, negação, disjunção e quantificação universal - e variáveis para classes de indivíduos, ou seja, variáveis que “representam nomes de classes indivíduos" (Tarski 1983[1933/1956]: 169) . Nesta linguagem não constam constantes individuais (nomes). Adotando a notação polonesa, Tarski simboliza as constantes da seguinte forma:

$$
\begin{aligned}
& \mathrm{N} \rightarrow \text { Negação } \\
& \mathrm{A} \rightarrow \text { Disjunção } \\
& \mathrm{I} \rightarrow \text { Inclusão } \\
& \Pi \rightarrow \text { Quantificação universal }
\end{aligned}
$$

e as variáveis para classes com índices subscritos

$$
\mathrm{X}_{\mathrm{I}}, \mathrm{X}_{\mathrm{II}}, \mathrm{X}_{\mathrm{III}}, \mathrm{X}_{\mathrm{IIII}}, \ldots
$$

Por fim, da concatenação das quatro constantes lógicas e as variáveis teremos as funções sentencias e sentenças da linguagem do cálculo das classes. Funções sentenciais e sentenças serão definidas mais à frente, após introduzirmos as expressões da ML, pois a definição de sentença também será dada na ML. Ilustremos algumas expressões da linguagem do cálculo das classes, formadas com as constantes e as variáveis acima expostas. Do lado esquerdo estão expressões da linguagem das classes, do lado direito, descrições do seu significado.

$$
\text { ,Nix } \mathrm{Ni}_{\mathrm{II}}{ }^{\text {ee }}
$$

\footnotetext{
${ }^{46}$ Ver Davidson $(1990 ; 2005)$.

${ }^{47}$ Uma generalização obtida a partir da Convenção- $T$ com respeito à ML deve ser observada: para qualquer definição de verdade que respeita o critério da adequação material, que tenha como consequência lógica sentenças- $\mathrm{T}$, a própria definição tem de ser uma sentença (da $M L$ ), pois somente sentenças têm sentenças como consequência lógica.
} 


$$
\begin{aligned}
& \text {,AIX } \mathrm{A}_{\mathrm{I}} \mathrm{x}_{\mathrm{II}} \mathrm{Ix}_{\mathrm{II}} \mathrm{X}_{\mathrm{I}}{ }^{e e} \\
& , \prod x_{i}{ }^{c e} \\
& , \prod \mathrm{x}_{\mathrm{I}} \mathrm{Ix}_{\mathrm{I}} \mathrm{x}_{\mathrm{I}}{ }^{e e} \\
& \text { "NIx } \mathrm{NI}_{\text {II }}{ }^{\text {ee }} \\
& \text {,II } \mathrm{III}_{\text {II }} \mathrm{X}_{\text {III }}
\end{aligned}
$$

Como pode ser notado, temos acima expressões mal formadas e bem formadas, assim como com variáveis livres e variáveis presas por quantificação universal. Serão as definições de função sentencial e sentença que regularão a identificação e especificação de cada uma das expressões ilustradas.

\subsection{Estrutura da metalinguagem}

Entre as expressões da ML podemos distinguir dois tipos. As de primeiro tipo seriam as expressões que Tarski chamou de "expressões de um caráter geral lógico" (Tarski 1983[1933/1956]: 170). Basicamente são expressões da lógica matemática e da teoria dos conjuntos. Entre elas estarão, por exemplo, expressões com o mesmo significado das constantes lógicas do cálculo das classes elencadas acima: negação, disjunção, inclusão, quantificador universal. Em virtude de a ML conter também essas constantes, poderemos traduzir nela as constantes da LO. Somadas a elas, teremos, ainda, símbolos para implicação, equivalência, quantificação existencial, identidade, nãoidentidade, pertinência e não-pertinência, números cardinais, números naturais, relações, etc. Isto é, expressões da lógica proposicional, de predicados, do cálculo das classes e teoria dos conjuntos. Essas expressões serão determinantes para empreender não somente a descrição da LO, mas também para forjar definições importantes para a introdução do conceito de satisfação. Por exemplo, o uso da expressão para relações de dois termos para definir sequência infinita de objetos/números e depois aplicá-la à definição de satisfação. Em suma, essas expressões serão mobilizadas, fundamentalmente, para definir verdade e regular, na ML, propriedades da LO.

Já as expressões de segundo tipo são os termos na ML que nomeiam os termos da LO. Por isso, chamá-las de expressões “de um caráter descritivo-estrutural” (Tarski 1983[1933/1956]: 172). Pertencem à ML também variáveis para as classes de indivíduos, sequências desses indivíduos, números naturais e seqüências de números naturais, expressões e classes de expressões. Ou seja, na ML é possível falar sobre as sentenças da LO, de conjuntos de sentenças com uma certa estrutura ou propriedade, das expressões que formam as sentenças, da sequência de números naturais que serão índices subescritos em expressões para classes de entidades, etc.

Antes de introduzir as definições de função sentencial e sentença, determinantes para a construção da definição de verdade, Tarski precisa de alguma maneira especificar, em ML, o que são as expressões da LO. Ele faz isso por meio da introdução de axiomas que regulam as expressões 
da LO. Não cabe aqui percorrê-los, basta destacar que esses axiomas precisam o vocabulário básico dos nomes descritivo.

Somado a isso, para preparar o vocabulário para definir função sentencial, Tarski introduz uma série de definições das operações fundamentais: inclusão, negação, quantificações universal e existencial. Com isso, define-se a operação básica, formadora de funções sentenciais - inclusão - , assim como a disjunção de inclusões de expressões, e as operações de negação e quantificação sobre expressões, que resultam em novas expressões.

Esses dois tipos de expressões da ML mostram que ela precisa tanto conter traduções de todas as expressões da LO, assim como nomes descritivo-estruturais dessas expressões. Nas sentenças-T, as traduções ocorrerão no definiens da equivalência, e os nomes descritivo-estruturais (que mencionam uma expressão) no definiendum. Numa sentença-T, então, traduz-se uma sentença referida por um nome. Por exemplo, o nome de uma sentença concreta como

$$
\prod \mathrm{x}_{\mathrm{I}} \prod \mathrm{x}_{\mathrm{II}} \mathrm{AIx}_{\mathrm{I}} \mathrm{x}_{\mathrm{II}} \mathrm{Ix}_{\mathrm{II}} \mathrm{x}_{\mathrm{I}}
$$

será, na notação de Tarski

$$
\bigcap_{1} \cap_{2}\left(\iota_{1,2}+\iota_{2,1}\right)
$$

onde $\cap$ nomeia o quantificador universal $\prod$, os numerais subescritos 1 e 2 nomeiam as variáveis para classes $\mathrm{x}_{\mathrm{I}}$ e $\mathrm{x}_{\mathrm{II}}$ respectivamente, + descreve a disjunção $\mathrm{A}$, e $\iota$ denota a inclusão $\mathrm{I}$.

Já quanto à tradução de , $\prod \mathrm{x}_{\mathrm{I}} \prod \mathrm{x}_{\mathrm{II}} \operatorname{AIx}_{\mathrm{I}} \mathrm{x}_{\mathrm{II}} \mathrm{Ix}_{\mathrm{II}} \mathrm{x}_{\mathrm{I}}^{\text {ee }}$ Tarski a apresenta em uma linguagem semiformalizada:

,para toda classe $a$ e $b$ temos $a \subseteq b$ ou $b \subseteq a^{\text {ee }}$

Substituindo no esquema- $T$,, ${ }^{\text {ee }}$ por,$\bigcap_{1} \cap_{2}\left(\iota_{1,2}+\iota_{2,1}\right)^{\text {ee }}$, e ,pe por ,para toda classe $a$ e $b$ temos $a \subseteq b$

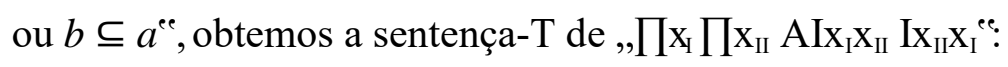

$$
\bigcap_{1} \cap_{2}\left(\iota_{1,2}+\iota_{2,1}\right) \text { é verdadeira } \leftrightarrow \text { para toda classe } a \text { e } b \text { temos } a \subseteq b \text { ou } b \subseteq a
$$

Geradas sentenças- $T$ na ML como a ilustrada acima, "explica-se de maneira precisa, em concordância com o uso linguístico, o significado de frases da forma „x é uma sentença verdadeirace que ocorrem nelas" (Tarski [1933] 1969: 187; trad. nossa). 
Tendo somente em conta a sentença- $T$ de,$\prod \mathrm{x}_{\mathrm{I}} \prod \mathrm{x}_{\mathrm{II}} \mathrm{AIx}_{\mathrm{I}} \mathrm{x}_{\mathrm{II}} \mathrm{Ix}_{\mathrm{II}} \mathrm{X}_{\mathrm{I}}$, é fácil perceber que a teoria não revela nada de novo sobre as condições de verdade da sentença de LO, que a própria sentença já não tenha expresso no seu significado. Mas o poder da teoria tarskiana não reside no fato de ela simplesmente apresentar uma lista de sentenças-T. A sua vantagem consiste em apresentar as condições de verdade das sentenças de uma LO como uma função das expressões que a formam e que ocorrem em outras sentenças. Isto é, a teoria mostra a contribuição de cada expressão na geração composicional e recursiva das condições de verdade das sentenças em que elas ocorrem. Por ora, ainda não expusemos como isso opera, pois ainda não temos à disposição as definições de função sentencial e sentença, tampouco a definição recursiva de satisfação, esta última responsável por explicitar o caráter composicional da definição semântica de verdade.

Primeiramente, então, tratemos das definições de função sentencial e sentença (ou em outra terminologia também usada por Tarski, sentença aberta e sentença fechada).

Tarski começa com a operação de inclusão como a operação básica formadora de funções sentenciais, e isso em virtude da LO sob investigação, que contém penas quatro constantes lógicas, sendo que a operação de negação, quantificação universal e disjunção são aplicadas quando funções sentencias já são formadas a partir da inclusão operando sobre variáveis para classes de indivíduos. Começemos com a função sentencial, porque sentença será caracterizada como um caso especial de função sentencial.

\section{Função sentencial e sentença como um caso especial de função sentencial.}

Vejamos a definição de função sentencial construída na Def 10 de "The Concept of Truth in Formalized Languages"

Definição 10: x é uma função sentencial se, e somente se, $x$ é uma expressão que satisfaz uma das seguintes quatro condições: $(\alpha)$ existe um número natural $\mathrm{k}$ e 1 tal que: $\mathrm{x}=\iota_{\mathrm{k}, \mathrm{l}} ;(\beta)$ existe uma função sentencial $\mathrm{y}$, tal que $\mathrm{x}=\bar{y} ;(\gamma)$ existem as funções sentenciais $\mathrm{y}$ e $\mathrm{z}$ tal que $\mathrm{x}=\mathrm{y}+\mathrm{z} ;(\delta)$ existe um número natural $\mathrm{k}$ e uma função sentencial y, tal que $\mathrm{x}=\cap_{\mathrm{k}} \mathrm{y}$. (Tarski 1983[1933/1956]: 177).

A cláusula $(\alpha)$ estipula que inclusões são funções sentenciais. $(\beta)$ garante que a negação de uma função sentencial é também uma função sentencial. $(\gamma)$, por seu turno, que uma disjunção de duas funções sentenciais resulta numa função sentencial. Por fim, $(\delta)$ assegura que uma quantificação universal consiste também em uma função sentencial.

Nesse sentido, de acordo com a Def. 10, pode-se distinguir quando estamos diante de uma função sentencial ou quando diante de uma expressão mal formada. Exemplos de funções sentenciais seriam: 


$$
\mathrm{Ix}_{\mathrm{I}} \mathrm{x}_{\mathrm{II}} ; \quad \mathrm{NIx}_{\mathrm{I}} \mathrm{x}_{\mathrm{II}} ; \quad \mathrm{AI} \mathrm{x}_{\mathrm{II}} \mathrm{x}_{\mathrm{IIII}} \mathrm{Ix}_{\mathrm{IIII}} \mathrm{x}_{\mathrm{I}} ; \quad \prod \mathrm{x}_{\mathrm{I}} \mathrm{NIx}_{\mathrm{I}} \mathrm{x}_{\mathrm{II}}
$$

Por outro lado, as expressões abaixo não são funções sentenciais:

$$
\prod ; \quad \mathrm{Ix} ; \quad \prod \mathrm{Ix}_{\mathrm{I}} \mathrm{x}_{\mathrm{II}}
$$

Como pode ser percebido, todas as funções sentenciais da LO negam ou afirmam inclusões, estabelecem disjunções de inclusões, quantificam universalmente, etc. Por essa razão, reiterando, a inclusão é a operação básica formadora de funções sentenciais. Outro elemento a ser destacado é que em todas as funções sentenciais ilustradas acima ocorrem variáveis livres, i.e., não presas por um quantificador universal, no caso da linguagem investigada por Tarski. Mesmo em,$\prod \mathrm{x}_{\mathrm{I}} \mathrm{NIx}_{\mathrm{I}} \mathrm{x}_{\mathrm{II}}{ }^{e}$ ocorre uma variável livre. Nesta função sentencial o quantificador prende somente „, $\mathrm{X}_{\mathrm{I}}^{\text {ce }}$, enquanto „, $\mathrm{X}_{\mathrm{II}}{ }^{e}$ ocorre livre. Para que ela não ocorra livre, é necessário um outro quantificador que a prenda. Assim, as funções sentenciais que não são do tipo sentença são aquelas nas quais ocorre ao menos uma variável livre. O papel das variáveis livres na atribuição de uma cláusula de satisfação para cada expressão da LO será determinante na geração recursiva das sentenças-T e para entendermos o que significará a definição de sentença verdadeira como sentença satisfeita por todas as sequências de classes de entidades. Quanto às expressões que não conformam funções sentenciais, isso ocorre porque ou falta alguma operação de inclusão, ou porque as outras constantes lógicas não ocorrem de forma correta: em „, $\mathrm{AIX}_{\mathrm{I}} \mathrm{X}_{\mathrm{II}}{ }^{\text {ee }}$ seria necessário mais uma inclusão, para aí sim aplicar a disjunção de duas inclusões, e em ,П $\mathrm{Ix}_{\mathrm{I}} \mathrm{x}_{\mathrm{II}}{ }^{e e} \mathrm{o}$ quantificador universal aparece sem uma variável, por isso a expressão é mal formada.

Em vista do que foi discorrido sobre as funções sentencias de LO e a noção de variável livre, fica fácil ver o que se configurará como uma sentença. Uma sentença será uma função na qual não ocorre nenhuma variável livre. No caso da LO de Tarski, isso só acontece quando quantificadores universais prendem todas as variáveis da função sentencial. Logo, serão sentenças somente funções sentenciais com quantificadores nas que não há nenhuma variável livre, uma vez que no vocabulário da LO em questão não há constantes individuais. Mesmo assim, a título de exposição, apresentemos a definição de sentenças: 
Definição 12. x é uma sentença (ou uma sentença significativa) [...] se e somente se $\mathrm{x}$ é uma função sentencial e nenhuma variável $\mathrm{v}_{\mathrm{k}}$ é uma variável livre da função $\mathrm{x}$. (Tarski 1983[1933/1956]: 178). ${ }^{48}$

Abaixo, alguns exemplos de sentenças da linguagem do cálculo das classes:

$$
\prod \mathrm{x}_{\mathrm{I}} \mathrm{Ix}_{\mathrm{I}} \mathrm{x}_{\mathrm{I}} ; \quad \prod \mathrm{x}_{\mathrm{I}} \prod \mathrm{x}_{\mathrm{III}} \mathrm{Ix}_{\mathrm{I}} \mathrm{x}_{\mathrm{III}} ; \quad \prod \mathrm{x}_{\mathrm{II}} \prod \mathrm{x}_{\mathrm{III}} \operatorname{AIx}_{\mathrm{II}} \mathrm{x}_{\mathrm{III}} \mathrm{Ix}_{\mathrm{III}} \mathrm{x}_{\mathrm{II}}
$$

Notem que nesses exemplos todas as variáveis estão ligadas por quantificadores universais, i.e., nenhuma está livre nas expressões.

Temos, até aqui, uma LO com sua estrutura especificada, com seu vocabulário e critérios de identificação das suas expressões, podendo distinguir uma sentença de uma outra expressão, assim como uma ML, com um vocabulário, recursos lógicos e definições que asseguram que tenhamos para cada expressão de LO um nome descritivo-estrutural e uma tradução da expressão, e construamos as sentenças-T. Ou seja, definida função sentencial, conseguimos, para cada função sentencial de LO, "automaticamente construir um nome descritivo-estrutural dessa função na metalinguagem" (Tarski [1933] 1969: 177), assim como uma tradução dela. Por conseguinte, dado que sentenças são formadas a partir de funções sentenciais, tendo um nome e uma tradução de cada função, com um método composicional, gero um nome e tradução para cada sentença de LO.

Agora que se construiu a linguagem na qual a definição de verdade será dada e a linguagem para qual a definição será empregada, finalmente podemos entrar na definição propriamente dita. Como já dito mais de uma vez ao longo do capítulo, a definição semântica de verdade será definida em função de outro conceito, o conceito de satisfação; e é aqui que residem a inovação técnica e a engenhosidade do método tarskiano.

\section{A definição em termos da relação de satisfação.}

Se Tarski estivesse interessado tão somente, por exemplo, na linguagem do cálculo proposicional, em que as expressões são apenas sentenças atômicas e conectivos verofuncionais, seria fácil dar

\footnotetext{
${ }^{48}$ Ao leitor interessado em percorrer todas as definições construídas na monografia de Tarski, ver a definirão 11, que ocorre antes da definição de sentença e consiste em especificar o que é uma variável livre. Para os propósitos deste capítulo, entendemos que é suficiente apenas descrever o que é uma variável livre, assim como outras expressões que recebem definições no texto, sem sobrecarregar este capítulo com definições que achamos não serem essenciais para que o leitor compreenda a definição semântica de verdade de Tarski. Esta postura também valerá para as definições construídas com o propósio de axiomatizar a linguagem das classes de modo concebê-la como uma linguagem das ciências dedutivas: definições tais como de consequência lógica, prova, completude, consistência, etc. Como a definição de verdade independe desta etapa, pois ela pode ser aplicada a linguagens formalizadas não axiomatizadas, i.e., com um vocabulário básico determinado e regras de formação de sentenças a partir deste vocabulário finito, detemo-nos na especificação do cálculo das classes como uma linguagem formalizada e adentraremos, em seguida, diretamente na definição de verdade para ela em termos de satisfação.
} 
uma caracterização recursiva de verdade fornecendo para cada sentença elementar da lógica proposicional uma sentença-T. Suponhamos que esta linguagem contenha cinco sentenças atômicas

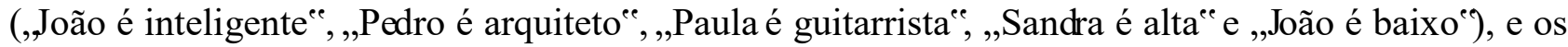
conectivos de conjunção, negação, disjunção e implicação. Além disso, as variáveis sentenciais „,P

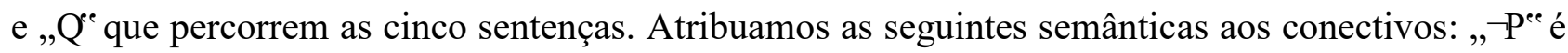
verdadeira $\leftrightarrow \mathrm{P}$ é falso; „P $\cdot \mathrm{Q}^{\mathrm{ec}}$ é verdadeiro $\leftrightarrow \mathrm{P}$ é verdadeira e Q é verdadeira; „P $\vee \mathrm{Q}^{\text {ee }}$ é verdadeira $\leftrightarrow \mathrm{P}$ é verdadeira ou $\mathrm{Q}$ é verdadeira; ,P $\rightarrow \mathrm{Q}^{\mathrm{ee}}$ é verdadeira $\leftrightarrow \mathrm{P}$ é falsa ou $\mathrm{Q}$ é verdadeira. Com isso, tendo o significado de cada conectivo à disposição, que pode ser exposto no método de tabela de verdade, pode-se construir a seguinte definição recursiva para esse fragmento de sentenças básicas:

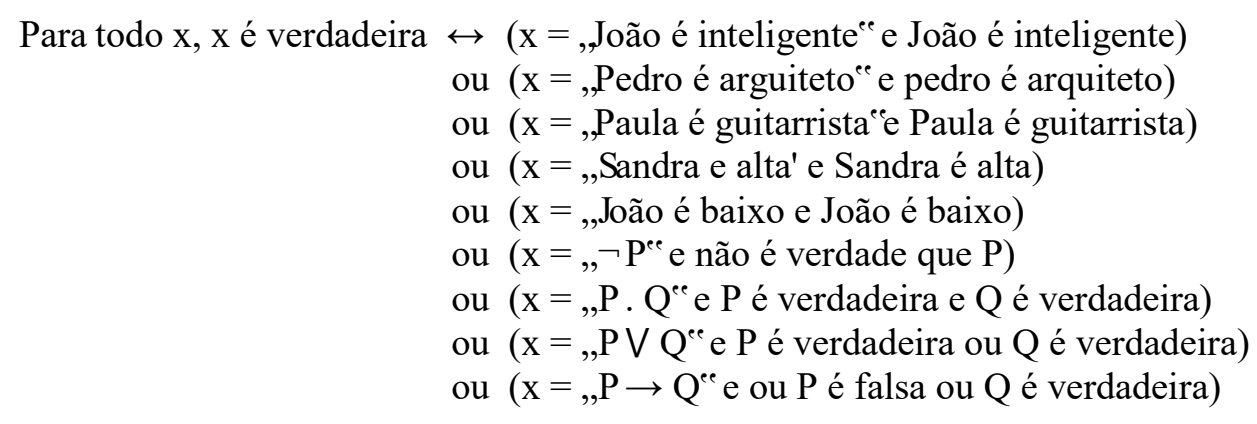

A definição precisa ser recursiva aqui porque, mediante a aplicação dos conectivos, a linguagem do cálculo proposicional pode engendrar infinitas sentenças. Com esse método recursivo consegue-se gerar para qualquer sentença elementar, como para qualquer sentença composta a partir dos conectivos lógicos, sua sentença-T. Por essa razão, uma definição como a acima, obedece à Convenção-T, pois tem para cada uma das sentenças da LO como consequência uma sentença da forma ' ' $x$ ' é verdadeira $\leftrightarrow p$ '.

No entanto, a linguagem para a qual Tarski define verdade é mais complexa, pois contem quantificadores e expressões com variáveis livres. Numa linguagem com esta estrutura, as sentenças não são formadas de sentenças básicas, mas pela composição de quantificadores universais e funções sentenciais. Em outros termos, pela combinação de duas expressões que não são sentenças. Há duas maneiras de transformar funções sentencias com variáveis livres em sentenças: substituindo a variável livre por um nome (o que não está à disposição da LO de Tarski) ou ligando as variáveis com quantificadores (único recurso disponível ao fragmento da LO em questão). Além disso, no fragmento da linguagem das classes investigado por Tarski é permitido formar funções sentenciais complexas usando conectivos e funções sentenciais. Ou seja, os conectivos podem ser aplicados a expressões com variáveis livres, que ainda não são sentenças, pois não foram quantificadas. Agumenta Tarski: 
A ideia de usar o método recursivo sugere a si mesma. Entre as sentenças de uma linguagem encontramos expressões de tipos mais variados do ponto de vista da estrutura lógica, algumas bastante elementares, outras mais ou menos complicadas. Seria então uma questão de primeiro dar todas as operações por meio das quais sentenças simples se combinam em compostas e então determinar o modo pelo qual a verdade ou falsidade das sentenças compostas depende da verdade ou falsidade das sentenças mais simples contidas nelas. Além disso, certas sentenças elementares poderiam ser selecionadas, a partir das quais, com a ajuda das operações mencionadas, todas as sentenças da linguagem poderiam ser construídas. $\mathrm{Na}$ tentativa de realizar esta idéia somos confrontados com um obstáculo sério. Até memo uma análise superficial de Defs. 10-12 [..] mostra que em geral sentenças compostas não são de nenhum modo compostas de sentenças simples. Funções sentenciais surgem [...] de funções elementares, i.e., de inclusões; sentenças por outro lado são casos especiais de funções sentenciais Em vista deste fato, nenhum método pode ser dado que nos permitiria definir o conceito requerido diretamente por meios recursivos. (Tarski 1983[1933/1956]: 189).

Aqui entra a vantagem do método de Tarski. O conceito de satisfação é uma noção semântica mais geral, como logo mais veremos, capaz de ser aplicada tanto a funções sentencias com variáveis livres quanto a funções sentenciais sem variável lívre. Satisfação será uma propriedade de ambas. E com esse conceito em mãos, poderemos definir as condições de verdade de sentenças quantificadas cujas partes são sentenças abertas como uma função das operações de satisfação aplicadas a essas partes. Sob essa descrição, é o conceito de satisfação (que será definido recursivamente) que garantirá que se construa uma definição recursiva para o cálculo das classes, assim como para a lógica de predicados, linguagens que possuem, além dos operadores verofuncionais, variáveis e quantificadores. Continua Tarski:

A possibilidade sugere a si mesma. [...] Introduzir um conceito mais geral que seja aplicável a qualquer função sentencial, que pode ser definido recursivamente, e, quando aplicado a sentenças, leva-nos diretamente ao conceito de verdade. Esses requerimentos são cumpridos pela noção de satisfação de uma função sentencial por dados objetos, e, no caso presente, por dadas classes de indivíduos (Tarski 1983[1933/1956]: 189).

Satisfação caracteriza-se como uma propriedade relacional, que estabelece uma relação entre uma sequência de objetos de um lado, e funções sentenciais do outro. Mas antes, comecemos de forma mais informal. Tomemos uma função sentencial com uma única variável, por exemplo, „x é azul ${ }^{e}$. Ela será satisfeita somente pelos objetos que são azuis. Assim, uma cláusula de satisfação para „x é azule seria:

Para todo objeto $a, a$ satisfaz a função sentencial „X é azule $\leftrightarrow a$ é azul. 
Por outro lado, um predicado relacional como ,x abraçou yee será satisfeito se, e somente se, o indivíduo x abraçou y. O mesmo com a função sentencial,$\downarrow_{1,2}{ }^{e e}$, ou seja, „Ix $\mathrm{I}_{\mathrm{I}} \mathrm{x}_{\mathrm{II}}{ }^{e}$. Podemos atribuir a ela a seguinte cláusula de satisfação:

Para toda classe $a$ e classe $b, a$ e $b$ satisfazem a função sentencial $\iota_{1,2} \leftrightarrow a \subseteq b$.

Mas como indicar que a variável x percorre um indivíduo que abraçou y, i.e., como indicar de forma uniforme essa relação? Como mostrar que $a$ e $b$ satisfazem a função acima, que $a$ e $b$ devem estar na relação afirmada? No caso de uma função com uma única variável falamos em objetos satisfazendo a função. Mas nos casos de funções sentenciais que estabelecem relações entre mais de um objeto, parece que temos de falar em conjuntos de pares ordenados satisfazendo essas funções. Contudo, Tarski está em busca de uma estratégia uniforme, que não tome entidades distintas satisfazendo distintas funções sentencias. Para as unárias, objetos, para as binárias, conjuntos de pares ordenados, por exemplo. Atento também, além disso, para os casos em que "uma dada função sentencial contém um número arbitrário de variáveis livres” (Tarski 1983[1933/1956]: 191), Tarski propõe, por causa de questões como as apontadas "que devemos daqui em diante dizer não que dados objetos, mas que sequências de objetos satisfazem uma dada função sentencial" (idem).

Uma sequência infinita de objetos, diferentemente de um conjunto, consiste numa sequência ordenada de objetos ${ }^{49}$, o que significa que a ordenação dos objetos é importante. Uma vez alterada a ordem dos objetos na sequência, modifica-se a sequência. Por exemplo, as duas sequências abaixo são distintas não pelos objetos que a formam, mas em decorrência da disposição dos objetos:

$\langle$ mesa, chuveiro, árvore, cachorro,... $\rangle$

$\langle$ mesa, árvore, cachorro, chuveiro,...〉

Uma sequência infinita não possui restrição quanto ao número de ocorrências de um mesmo objeto na sequência, de maneira que

$\langle$ mesa, mesa, mesa, mesa, chuveiro,...〉

também é uma sequência. Lembremos que as variáveis para classes na LO de Tarski ocorrem enumeradas em uma sequência, e que as expressões que nomeiam na ML as variáveis da LO estão também enumeradas, de maneira a explicitar essa correspondência entre as variáveis e seus nomes.

\footnotetext{
${ }^{49}$ Uma sequência é uma relação um-muitos tal que o contradomínio é a classe dos números naturais, exceto o 0.
} 
As classes que ocorrem nas sequências infinitas também receberão índices numéricos indicando a sua posição nas sequências. A estratégia é estabelecer uma relação de um-para-muitos entre as variáveis de uma função sentencial e os termos de uma sequência $f$ qualquer. Para toda variável corresponderá um elemento na sequência com o mesmo índice dela. Para uma sequência satisfazer uma função sentencial, teremos somente que olhar para o termo na sequência que possui o mesmo índice da variável. Um termo $f_{10}$ corresponderá na sequência à variável $v_{10}$ de uma função sentencial. Uma função sentencial como ,, $v_{10}$ é vermelho ${ }^{\text {ee }}$ será satisfeita por uma sequência $f$, se e somente se, o termo com índice 10 na sequência é vermelho. Mostremos esse procedimento com um exemplo concreto do cálculo das classes apresentado por Tarski ${ }^{50}$. A função sentencial , $\bigcap_{2} \iota_{1,2}{ }^{\text {ee }}$ será satisfeita por uma sequência infinita $f$ de classes de indivíduos se e somente se o termo $f_{1}$ da sequência, qualquer que seja a classe $b$, estiver contido em $b .^{51}$

Quanto às funções predicativas, tais como „, $v_{1}$ abraçou $v_{234}{ }^{\text {ee }}$, uma sequência $f$ a satisfará se, e somente se, o termo $f_{1}$ da sequência abraçou o termo $f_{234}$ da mesma sequência. Em posse desse método de sequência de objetos, não preciso postular conjuntos de pares ordenados que satisfazem funções binárias. Mediante sequências infinitas, consegue-se homogeneizar o método: funções sentenciais, quaisquer que elas sejam, serão satisfeitas por sequências de objetos.

Tarski formula, então, a definição recursiva geral de satisfação para LO da seguinte maneira:

Definição 22. A sequência $f$ satisfaz a função sentencial x se e somente se $f$ é uma sequência infinita de classes e $\mathrm{x}$ é uma função sentencial e $\mathrm{x}$ e $f$ são tais que ou $(\alpha)$ existem os números naturais $k$ e $l$ tal que $\mathrm{x}=\iota_{\mathrm{k}, 1}$ e $f_{\mathrm{k}} \subseteq f_{1}$; $(\beta)$ existe uma função sentencial y tal que $\mathrm{x}=\overline{\mathrm{y}}$ e $f$ não satisfaz a função $\mathrm{y} ;(\gamma)$ existem as funções sentenciais y e $\mathrm{z}$ tal que $\mathrm{x}=\mathrm{y}+\mathrm{z}$ e ou $f$ satisfiz y ou satisfaz $\mathrm{z}$; ou por fim $(\delta)$ existem um número natural $\mathrm{k}$ e uma função sentencial y tal que $\mathrm{x}=\bigcap_{\mathrm{k}} \mathrm{y}$ e toda sequência infinita de classes que difere de $f$ no máximo no k-ésimo lugar satisfaz a função y (Tarski 1983[1933/1956]: 193).

O conceito acima definido cobre todas as possíveis realizações concretas das funções sentenciais do cálculo das classes. A cláusula $(\alpha)$ especifica quando uma inclusão de variáveis para classes é satisfeita por uma sequência, a saber, quando a classe $f_{\mathrm{k}}$ de uma sequência $f$, que tem o mesmo índice da variável $\mathrm{k}$ da função, está contida na classe $f_{1}$ da mesma sequência, que possui também o mesmo índice da variável $l$ da função. ( $\beta$ ) determina que uma sequência satisfaz a negação de uma função quando ela não satisfaz a função negada. $(\gamma)$ assegura que uma sequência satisfaz uma

\footnotetext{
${ }^{50}$ Ver páginas 191-192 da monografia de Tarski.

${ }^{51}$ É fácil ver neste exemplo que esta classe tem de ser a classe vazia.
} 
disjunção de duas funções se, e somente se, ela satisfaz ao menos uma das duas funções. Já a quantificação universal, contemplada na cláusula $(\delta)$, "pede uma consideração especial” (Tarski 1983[1933/1956]: 192), como salienta Tarski, dada a maior complexidade da sua cláusula de satisfação.

Tomemos, então, uma função sentencial x qualquer. E suponhamos que saibamos quais sequências infinitas de classes de indivíduos satisfazem esta função. Tenhamos também em conta a operação do quantificador universal. Isto posto, dada a nossa definição de satisfação, perguntemos:

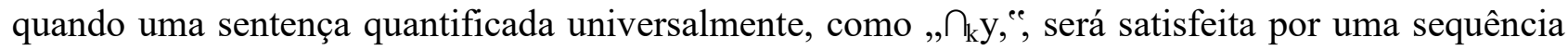
de classes? Uma sequência $f$ qualquer satisfaz „, $\cap_{\mathrm{k}} \mathrm{y}^{\text {ee }}$ se, e somente se, toda sequência $f$ ' que difere de $f$ no máximo no k-ésima termo, também satisfaz a função y. Isso significa que toda sequência que difere de $f$ no máximo no k-ésima lugar, ou seja, que difere na classe que ocupa esta posição, também satisfaz y porque a classe na k-ésima posição de $f$, assim como a classe na $k$-ésima posição $f$, cai sob a função y.

Como então uma sequência $f$ qualquer satisfaz a sentença , $\forall v_{10}: v_{10}$ é azulee? ${ }^{52}$ Somente quando (i) $f$ satisfaz a função sentencial,$v_{10}$ é azul ${ }^{\text {ee }}$, e isso ocorre quando o termo $f_{10}$ da sequência é azul; e (ii) tal função sentencial é satisfeita por toda sequência $f^{\prime}$ que difere de $f$ no máximo no termo $f^{\prime}{ }_{10}$, e o termo $f^{\prime}{ }_{10}$ também é azul.

Suponhamos que nossa LO contenha também o quantificador existencial. De acordo com o significado do existencial, que consiste em dizer que ao menos a um indivíduo em um domínio se aplica uma função sentencial $\Phi$ qualquer, é fácil de perceber a cláusula de satisfação que uma função sentencial da forma $, \exists v_{k}: \Phi\left(v_{k}\right)^{\text {ee }}$ deve receber. A cláusula é a que se segue:

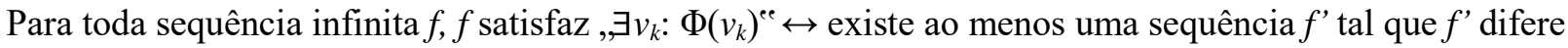
de $f$ no máximo no k-ésimo lugar e $f$ ' satisfaz „, $\Phi\left(v_{k}\right)^{e c}$.

As expectativas de Tarski com a Def. 22 de satisfação não é somente que o conceito de verdade possa ser definido em função do conceito de satisfação, mas também outros conceitos semânticos:

O conceito que acabou de ser definido [Def 22] é da maior importância para investigações da semântica da linguagem. Com sua ajuda os significados de uma série de conceitos neste campo podem facilmente ser definidos; por exemplo, os conceitos de denotação, definabilidade e verdade, sendo este último conceito com qual estamos especialmente preocupados aqui. (Tarski 1983[1933/1956]: 193-194).

\footnotetext{
${ }^{52}$ Adoto aqui o símbolo padrão „, $\forall$ ee para o quantificador universal.
} 
Em sua defesa do uso consistente dos conceitos semânticos, Tarski aventa na definição de satisfação a possibilidade de unificar tais conceitos, no sentido de definí-los todos em termos de satisfação. Vejamos a conceito de denotação, por exemplo, empregado recorrentemente na caracterização do significado das constantes individuais. É importante nos determos aqui um pouco, pois termos singulares são expressões das línguas naturais, e terão de ser tratados pela teoria semântica de Davidson. Qual seria, então, a solução em termos de satisfação para a denotação de constantes individuais (nomes, termos singulares) em linguagens que contêm tais expressões? Em nota Tarski propõe:

Dizer que o nome de $\mathrm{x}$ denota um dado objeto $a$ é o mesmo que estipular que o objeto $a$ (ou toda sequência em que $a$ é o termo correspondente) satisfaz uma função sentencial de um tipo particular. Na linguagem coloquial ela seria uma função que consiste de três partes na seguinte ordem: uma variável, a palavra ,éé, e o nome x. (Tarski 1983[1933/1956]: 194).

Uma cláusula de satisfação para uma constante individual como ,,joão , seria, então:

Para todo $f, f$ satisfaz a função sentencial ,, $\mathrm{V}_{\mathrm{k}}$ é joão ${ }^{\text {ee }} \leftrightarrow$ o termo $f_{\mathrm{k}}$ de $f$ é joão.

Por meio da cópula e introdução de uma variável Tarski reescreve constantes individuais como funções sentenciais. ${ }^{53}$

Voltemos para a definição de verdade, pois com a definição de satisfação já construída estamos muito próximos dela. Lembremos que as sentenças são um caso especial de função sentencial, i.e., em que não ocorrem variáveis livres. Elas são formadas da combinação de quantificadores e funções sentenciais com variáveis livres, e nenhuma das partes de uma sentença precisa ser uma sentença. Do que se deduz que as condições de satisfação de uma sentença é uma função das condições de satisfação atribuídas as suas unidades que as constiuem. A satisfação de uma sequência por uma função sentencial depende unicamente das entidades que a sequência

\footnotetext{
${ }^{53} \mathrm{O}$ leitor familiarizado com o debate sobre nomes próprios notará que esta solução se assemelha muito com a proposta de Quine, em Word and Object (1960), de traduzir os termos singulares como expressões predicativas (na terminologia de Quine, termos gerais) aplicáveis a um único indivíduo, com o intuito de mostrar que nomes próprios podem ser eliminados via a substituição de sentenças que os contém por sentenças contendo variáveis presas por quantificação existencial. Com a diferença que nas paráfrases de Quine, em vez de haver introduzão de uma cópula, numa postura ainda mais artificial, os nomes são reescritos como predicados. O debate sobre os nomes próprios é um dos mais controversos em filosofia da linguagem, e há uma infindável literatura sobre o assunto. $\mathrm{O}$ intuito aqui é claramente de não apresentar posições divergentes sobre a natureza dos nomes próprias. Mas unicamente de demonstrar que a estratégia de Tarski, ao introduzir variável e a copula, toma os nomes como um tipo de função sentencial, e, com isso, consegue tratar denotação em termos de satisfação. Ao mesmo tempo em que não se pode negligenciar que uma solução como esta pode ser fruto de uma tomada de posição quanto ao papel semântico dos nomes próprios, e, como tal, pode estar sujeito a objeções convincentes.
} 
atribui às variáveis livres das funções sentenciais. Nas palavras de Tarski: “[...] se uma dada sequência satisfaz ou não uma dada função sentencial depende somente daqueles termos da sequência que correspondem (em seus índices) às variáveis livres da função" (Tarski 1983 [1933/1956]: 194). Nesse sentido, quando se forma composicionalmente uma sentença, não há mais variáveis para corresponder a termos de sequências. A consequência, nada intuitiva, é que as sentenças verdadeiras serão satisfeitas por todas as sequências infinitas e sentenças falsas por nenhuma sequência. Cada sentença terá sua história, por assim dizer, composicional, gerando suas condições de verdade como uma função das condições de satisfação das expressões que a formam. Mas a verdade de uma sentença significará que ela é satisfeita por todas as sequências, e a falsidade por nenhuma. Dito isto, a definição de „x é uma sentença verdadeira em L $L^{c e}$ em termos de satisfação está diante de nós. E Tarski a apresenta na Def. 23. Vejamos:

Definição 23. $\mathrm{x}$ é uma sentença - em símbolos $\mathrm{x} \in \mathrm{Tr}$ - se e somente se $\mathrm{x} \in \mathrm{S}$ e toda sequência infinita de classes satisfaz x. (Tarski 1983 [1933/1956]: 195)

Uma sentença denotada por,$\bigcap_{1} \iota_{1,1}$ e será um exemplo de sentença verdadeira, pois afirma que toda classe está contida em si mesma; já , $\bigcup_{1} \overline{\iota 1,1}^{e 54}$ é um exemplo de sentença falsa, pois afirma que existe uma classe que não está contida em si mesma.

Aqui o leitor pode se perguntar: bom, chegou-se a uma definição de verdade em termos de satisfação, mas como mostrar que a Def 23 é materialmente adequada, ou seja, que segue a Convenção- $T$, que dela se extrai como consequência , $\mathrm{x} \in \operatorname{Tr} \leftrightarrow \operatorname{trad}(\mathrm{x})^{\text {ee }}$ para cada sentença do cálculo das classes? Tarski argumenta que para essa pergunta há uma resposta positiva. Contudo, a sua formulação exige que alcemos na hierarquia das linguagens, e que se construa a prova numa meta-metalinguagem. Contudo, para tanto o trabalho seria hercúleo, pois teria-se que construir as expressões dessa linguagem, os meios de falar na meta-metalinguagem sobre a metalinguagem, estabelecer uma série de axiomas e definições, etc. Além disso, a meta-metateoria "teria que ser precedida pela formalização da metateoria que forma a fundação das nossas investigações" (Tarski 1983[1933/1956]: 195). O estabelecimento de todo o aparato demandaria um esforço que tornaria o trabalho extremamente longo e de difícil absorção. A estratégia de Tarski para defender a adequação da sua definição consistirá apenas "na verificação das propriedades da Def. 23 em uma série de exemplos concretos", que, uma vez percorridos, podem servir de casos paradigmáticos da adequação material da definição. Mas uma prova de que a Def. 23 obedece à Convenção-T não é

\footnotetext{
${ }^{54} \mathrm{O}$ símbolo „U“e nomearia um termo da LO que expressa quantificação existencial (mas recordem que o fragmento do cálculo das classes que Tarski toma como LO não contém uma expressão para quantificação existencial) e a o traço sobre,$_{1,1}$ "enomeia a expressão de negação, que significa que se está negando uma inclusão.
} 
apresentada na monografia ${ }^{55}$. Tarski apostará que "o leitor sem dúvida terá alcançado a convicção subjetiva" (Tarski 1983 [1933/1956]: 197), pelo exemplo concreto apresentado de uma sentença, de que a definição é materialmente adequada.

Com as definições 22 e $\mathbf{2 3}$ Tarski demonstra, passo a passo, como que elas garantem gerar como consequência a sentença- $T$ correta na ML da sentença , $\prod \mathrm{x}_{I} \mathrm{~N} \prod \mathrm{x}_{\mathrm{II}} \mathrm{NIx}_{\mathrm{I}} \mathrm{x}_{\mathrm{II}}{ }^{e e}$ da $\mathrm{LO}$. O nome desta sentença na $M L$ é $\bigcap_{1} \cup_{2} \iota_{1,2}$. Tarski apresenta as etapas de obtenção da sentença- $T$ de ,$\prod \mathrm{x}_{\mathrm{I}} \mathrm{N} \prod \mathrm{x}_{\mathrm{II}} \mathrm{NIx}_{\mathrm{I}} \mathrm{x}_{\mathrm{II}}{ }^{\text {ee }}$ como teorema, da seguinte forma:

De acordo com a Def. 22 de função sentencial, $\iota_{1,2}$ é satisfeita por aquelas, e somente aquelas, sequências $f$ de classes às quais $f_{1} \subseteq f_{2}$ se aplica, mas sua negação, i.e., a função $\overline{l_{1,2}}$, somente pelas sequências às quais $f_{1} \nsubseteq f_{2}$ se aplica. Consequentemente, uma sequência $f$ satisfaz a função $\cap_{2} \overline{l_{1,2}}$, se toda sequência $g$ que difere de $f$ no máximo no segundo lugar satisfaz a função $\overline{\iota_{1,2}}$, e então verifica $g_{1} \nsubseteq g_{2}$. Dado que $g_{1}=f_{1}$ e classe $g_{2}$ pode ser bastante arbitrária, somente satisfazem a função $\cap_{2} \overline{l_{1,2}}$ aquelas sequências $f$ tais que $f_{1} \nsubseteq b$. Se procedermos de um modo análogo, alcançamos o resultado de que a sequência $f$ satisfaz a função $\cup_{2} \iota_{1,2}$, i.e., a negação da função $\cap_{2} \overline{\iota_{1,2}}$, , somente se existe uma classe b à qual $f_{1} \subseteq$ b se aplica. Além disso, a sentença $\bigcap_{1} \cup_{2} \iota_{1,2}$ é somente satisfeita (por uma sequência arbitrária $f$ ) se existe para uma classe arbitrária $a$, uma classe $b$ para a qual $a \subseteq b$ (Tarski 1983[1933/1956]:196).

Apresentadas todas as etapas composicionais das condições de satisfação que geram recursivamente as condições de verdade de,$\prod \mathrm{x}_{\mathrm{I}} \mathrm{N} \prod \mathrm{x}_{\mathrm{II}} \mathrm{NIx}_{\mathrm{I}} \mathrm{x}_{\mathrm{II}}{ }^{\text {ee }}$, basta introduzir a Def. 23, que temos, então, como consequência o teorema:

$\cap_{1} \cup_{2} \iota_{1,2}$ é verdadeira $\leftrightarrow$ para todas as classes $a$ existe uma classe $b$ tal que $a \subseteq b$.

Isto é, a sentença,$\prod \mathrm{x}_{\mathrm{I}} \mathrm{N} \prod \mathrm{x}_{\mathrm{II}} \mathrm{NIx}_{\mathrm{I}} \mathrm{x}_{\mathrm{II}}{ }^{\mathrm{e}}$ é verdadeira somente quando para cada classe tem-se ao menos uma classe na qual ela está contida. Para o leitor familiarizado com a lógica das classes, é fácil notar que esta é uma sentença verdadeira. ${ }^{56}$

Embora todas as sentenças verdadeiras, no método de Tarski, levem ao mesmo "lugar" uma vez que são satisfeitas por todas as sequências de objetos - suas estruturas são descritas em

\footnotetext{
${ }^{55}$ Muito menos nos textos de divulgação da sua concepção semântica, onde a defesa da definição se dá toda em linguagem coloquial, acessível a um público maior.

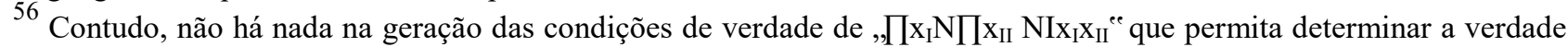
desta sentença. A Def. 23, introduzida para gerar a sentença-T acima ilustrada, "sozinha não dá um critério geral para verdade de uma sentença. Contudo, através dos teoremas obtidos, o significado das expressões correspondentes do tipo „X $\in \operatorname{Tr}^{\text {ec }}$ se torna inteligível e não-ambíguo” (Tarski 1983[1933/1956]: 197). A definição semântica de Tarski não fornece um método de verificação da verdade das sentenças de uma linguagem, e nem é desenhada para isso. O que ela fornece é um método de geração composicional das condições suficientes e necessárias da verdade das sentenças.
} 
termos de satisfação das funções sentencias que as constituem, sendo que diferentes atribuições de entidades a diferentes variáveis satisfazem diferentes funções sentenciais. Cada sentença terá um percurso composicional distinto que gera, ao final, um teorema - que é a sua sentença-T -, expondo, em cada etapa, as condições de satisfação que cada função sentencial que forma uma sentença possui e que contribui, semanticamente, na conformação das suas condições de verdade. Isso porque é o axioma ou cláusula de satisfação atribuída a cada expressão que vincula linguagem e um universo de discurso. 5758

A definição de verdade até aqui discutida foi atingida mediante uma série de passos. Mas o fundamental é ter em mente que, primeiramente, há uma definição do que são sentenças abertas e fechadas e então uma caracterização recursiva de satisfação (na forma de uma definição explícita). E, por fim, verdade é definida com base nos conceitos de função sentencial e satisfação. A introdução da relação de satisfação para caracterizar verdade estabelece relações entre as expressões formadoras de sentenças (em especial sentenças abertas) e sequências de objetos ou objetos. As condições de verdade das sentenças são explicitadas pelo apelo a propriedades semânticas das expressões constituidoras de sentenças. A conexão entre expressões da linguagem e objetos no mundo se dá via propriedades das palavras (fundamentalmente expressas em suas cláusulas de satisfação).

O otimismo de Davidson quanto à concepção semântica de verdade de Tarski resulta diretamente do fato de Davidson acreditar que a definição de verdade em função da relação de satisfação, pela primeira vez, conseguiu fornecer um método claro e rigoroso de caracterizar recursivamente a contribuição semântica das palavras na derivação das condições de verdade das sentenças. Porque, na perspectiva do filósofo, uma teoria da verdade de tipo tarskiana pode fornecer composicionalmente as condições de verdade das sentenças e exibir traduções das sentenças de uma LO sem reificar significado, Davidson enxerga no método de Tarski um instrumento que pode ser adaptado como veículo de uma teoria semântica das linguagens naturais, da produção e interpretação linguística. A serviço de uma teoria semântica empírica, e sofrendo as modificação

\footnotetext{
${ }^{57}$ Sobre esses diferentes caminhos composicionais que diferentes sentenças percorrem, sublinha Davidson: "[...] verdade é alcançada, na abordagem semântica, por diferentes rotas para diferentes sentenças. Todas as sentenças verdadeiras terminam no mesmo lugar, mas há diferentes estórias sobre como elas chegaram lá; uma teoria semântica da verdade conta a estória de uma sentença particular percorrendo os passos da explicação recursiva de satisfação apropriada a sentença” (Davidson 1990 [1969]: 49).

${ }^{58}$ Como deve ficar claro para o leitor na nossa discussão até agora, o objetivo de Tarski, ao assumir verdade como uma propriedade de sentenças, consiste em implementar uma definição que fixa a extensão do predicado ,x é verdadeira ${ }^{e e}$, i.e., capturara a classe das sentenças verdadeiras em uma linguagem particular. Tarski não intenta capturar o que se pode chamar de a intensão do predicado, no sentido de elucidar uma camada de significado distinta da extensão do termo. A definição de Tarski ilumina a extensionalidade, relativa a uma linguagem, do conceito de verdade.
} 
necessárias, seria um valioso instrumento para iluminar, com recursos formais, o aspecto composicional do significado nas línguas naturais.

Como examinado na seção sobre a antinomia do mentiroso, o ceticismo de Alfred Tarski quanto à aplicabilidade do seu método à linguagem coloquial repousa sobre o argumento robusto de que as línguas naturais engendariam paradoxos. Contudo, além desse argumento principal contra a possibiliade de definir verdade para linguagens que contêm termos semânticos, em especial o predicado de verdade, Tarski aponta outro aspecto, nada negligenciável, das línguas naturais que poderia bloquear ou dificultar a aplicação da sua definição a elas. Examinemos, então, na próxima seção essas pondenrações de Tarki.

\section{As línguas naturais não seriam formalmente especificáveis?}

Tarski aponta outra dificuldade no caminho do otimismo acerca de um tratamento formal das línguas naturais em conformidade com o seu critério. Ele afirma que a sintaxe das línguas naturais não seriam formalmente especificáveis. $\mathrm{O}$ argumento é de que uma evidência da ausência de uma sintaxe precisamente definida nas línguas naturais estaria expressa na dificuldade de se precisar quando uma expressão de uma língua natural é uma sentença. Há inúmeros contextos em que expressões lexicais funcionam como sentenças e sentenças funcionam como nomes. Mas uma teoria formal e recursiva da verdade para uma linguagem L exige uma especificação recursiva das expressões de L que garanta que, em posse de uma definição puramente sintática de sentença, possa-se descrever cada sentença de L como composta a partir de suas unidades constitutivas. Sem isso não seria possível atribuir condições de verdade com base em axiomas (ou cláusulas de uma definição explícita) formados com os termos primitivos de L. Recordem que o portador de verdade em Tarski são sentenças. Verdade é um predicado de sentenças. Do que se segue que, se não se pode determinar com precisão, com base em propriedades estruturais, quando uma expressão de uma linguagem L é uma sentença, tampouco posso definir o predicado de verdade para ela. Uma consequência ainda mais radical é que, sem um critério preciso sintático de distinção das expressões da linguagem, conclui Tarski, nem sequer posso investigar se tal linguagem L é semanticamente fechada ou não.

Nossa linguagem cotidiana não é certamente uma [linguagem] com uma estrutura especificada de forma exata. Não sabemos precisamente quais expressões são sentenças, e sabemos ainda num grau menor quais sentenças são para ser tomadas como assertíveis. Assim, o problema da consistência não tem nenhum significado exato com respeito a essa linguagem. Podemos no melhor apenas arriscar o palpite de que uma linguagem cuja estrutura foi especificada de forma exata e que se assemelha a nossa linguagem cotidiana o mais próximo possível cria inconsistente. (Tarski 1944: 349). 
A citação acima sugere que Tarski assume que, uma vez que recortamos um fragmento da linguagem coloquial para com esse fragmento exemplificar as propriedades de uma linguagem inconsistente, já impomos sobre as linguas naturais uma forma de semi-regimentação externo a elas. E é fácil de ver a razão disso. Para gerar o paradoxo do mentiroso adota-se a postura de que expressões usadas são sentenças e que os predicados semânticos são propriedades dessas sentenças. Sem postular isso de antemão é impossível de reconstruir a antinomia. O que ocorre é que Tarski, intencionalmente, supõe que a estrutura das línguas naturais são especificáveis, que os termos que emprega têm significados precisos (sem margens para ambiguidade), com o intuito metodológico de ilustrar, num fragmento bastante semelhante a expressões de uma língua natural, que as linguagens com estrutura especificada, mas semanticamente fechadas, são inconsistentes. Pois, rigorosamente falando, o problema da inconsistência das línguas naturais não poderia nem sequer ser checado, i.e., não se poderia nem afirmar nem negar se elas são fechadas ou não. Ainda que um fragmento com uma estrutura precisa atribuída a ele, bastante próximo de um linguagem coloquial, indique, de forma indireta, que se fosse passível submeter a linguagem coloquial a métodos exatos sua inconsistência imediatamente emergiria.

Retomando a hipótese da inconsistência das línguas naturais (ou melhor, das linguagens semanticamente fechas), e indicando outros aspectos que dificultam tratá-las à luz do seu método, Tarski reforça, nas últimas páginas de "The Concept of Truth in Formalized Languages":

[...] O conceito de verdade (assim como outros conceitos semânticos) quando aplicado à linguagem coloquial em conjunção com as leis normais da lógica leva inevitavelmente a confusões e contradições. Quem quer que deseje, apesar de todas as dificuldades, perseguir a semântica da linguagem coloquial com a ajuda de métodos exatos será levado primeiro a empreender o trabalho ingrato de uma reforma dessa linguagem. Ele achará necessário definir sua estrutura, superar a ambiguidade dos termos que ocorrem nela, e, por fim, dividir a linguagem em uma série de linguagens de maior e maior extensão, cada uma das quais está na mesma relação com a próxima tal como uma linguagem formalizada está com a metalinguagem. Pode, contudo, ser duvidado se a linguagem da vida diária, depois de ser "racionalizada" deste modo, ainda preservaria sua naturalidade e se ela não assumiria as características próprias das linguagens formalizadas (Tarski 1983 [1933/1956]: 267).

Tarski argumenta aqui que, dado o aspecto amorfo das línguas naturais, a sua subdeterminação estrutural - i.e., a ausência de expressões no seu interior com propriedades distintivas claras e de precisa identificação - aplicar um método formal a elas com o propósito de elucidar formalmente a sua estrutura semântica, requer, antes, uma regimentação da linguagem em uma linguagem formalizada, ou semi-formalizada para a qual possuímos uma teoria. Um exemplo desta estratégia é 
reescrever fragmentos da linguagem ordinária com o maquinário da linguagem de predicados. Para isso, faz-se necessário encontrar um método de eliminação da ambiguidade semântica em língua natural, que se prolifera tanto no nível lexical quanto sentencial. Todavia, Tarski suspeita desta empreitada. Uma suspeita com base em uma justificativa bastante convincente: regimentar a linguagem coloquial desta maneira seria uma forma de impor a lógica de uma linguagem artificial a uma linguagem natural. Ou seja, por meio desse método não se estaria, ao invés de descrever a estrutura de semântica de uma língua natural, reformando a linguagem e purgando ela das especificidades que dificultam o seu tratamento por um método formal? Para Tarski, é justamente isso que acaba correndo. No afã de formalizar a linguagem natural para torná-la suscetível de ser descrita por uma teoria da verdade à lá Tarski, acaba-se muito mais prescrevendo estruturas do que realmente descrevendo.

Como pode ser visto, os desafios impostos ao semantista e filósofo otimista quanto à possibilidade de estender uma teoria da verdade de tipo tarskiana para as línguas naturais não são nada fáceis de enfrentar. As abjeções fornecidas por Tarski são robustas, e não podem ser diminuídas, muito menos evitadas, se o objetivo for realmente sustentar de forma séria que uma definição à lá Tarski para as línguas naturais pode ser formalmente consistente e obedecer ao critério de adequação material. Os problemas apontados por Tarski são, entre outros tópicos, decisivos para a validação de se o programa davidsoniano pode cumprir a generalidade a que se propõe como uma semântica composicional das línguas naturais, ou até para a viabilidade como uma teoria parcial, necessariamente circunscrita a fragmentos de linguagem. Por essa razão, esses tópicos serão também retomados no próximo capítulo.

\section{Síntese informal da definição de Tarski.}

Nos seus trabalhos mencionados sobre verdade Tarski tem por objetivo uma definição de „sentença verdadeira $^{e e}$ para um conjunto de linguagens formais. Em particular, ele produziu uma definição de predicado de verdade para a linguagem que ele chamou de cálculo das classes. Tal linguagem é conformada por variáveis subescritas para classes, $\mathrm{x}_{1}, \mathrm{x}_{2}, \mathrm{x}_{3}$ (na verdade, Tarski emprega riscos subescritos, mas a noção com números nos parece mais legível), dois conectivos sentenciais negação e disjunção - um quantificador universal e um predicado de dois lugares - representado pelo sinal „ঙe -, cujo significado é a operação de inclusão, i.e., „é incluso eme . O cálculo das classes, sendo a linguagem para a qual o predicado de verdade é definido, é chamada de linguagem objeto (LO). A linguagem na qual é construída a definição, por sua vez, é a metalinguagem (ML). As sentenças da linguagem estudada, ou seja, da LO, são as fórmulas bem formadas nas quais não ocorrem variáveis livres. Uma característica crucial da sua definição é que para cada sentença $s$ de 
LO, deve haver em ML uma descrição estrututal de $s$ e uma tradução dela. Com isso em mãos, Tarski pode introduzir o seu famoso critério de adequação de uma definição de verdade para uma linguagem. Esse critério, chamado de Convenção- $T$, estipula que para uma definição adequada de „, é verdadeira em L $L^{c e}$, em que L é a linguagem objeto, é necessário que tenhamos como consequência lógica todas as sentenças obtidas a partir do esquema „x é verdadeira se, e somente se, $\mathrm{p}^{\mathrm{ee}}$, substituindo por , $\mathrm{X}^{\text {ee }}$ uma descrição estrutural de uma sentença de $\mathrm{L}$, e por $p$ uma tradução na metalinguagem da sentença de L descrita no lado esquerdo da equivalência. No caso de linguagens com um número infinito de sentenças, Tarski sugere que a definição pode ser recursiva, de maneira que se define, em primeiro lugar, o predicado de verdade para as sentenças mais simples, e, em seguida, mostra-se como a verdade ou falsidade das sentenças complexas pode ser definida em função da verdade ou falsidade das sentenças simples.

Contudo, como no caso do cálculo das classes, em linguagens nas quais ocorrem expressões quantificacionais, há sentenças não são formadas a partir de sentenças, mas a partir da concatenação de uma expressão quantificacional e fórmulas com variáveis livres. Tanto para um quantificador quanto para uma expressão com variável livre não é possível aplicar diretamente o predicado de verdade. Em vista disso, Tarski propõe introduzir o conceito semântico de satisfação (que estabelece uma relação entre expressões de uma linguagem e objetos), o qual pode ser aplicado a todas as expressões subsentenciais de uma linguagem objeto, e em função do qual a noção de verdade pode ser definida. Para definir satisfação Tarski recorre a sequências $f$ infinitas de objetos, no caso da sua linguagem objeto, sequências de classes. Para tanto, Tarski determina que o $k$-ésimo elemento de uma sequência $f$ esteja associado com a variável $\mathrm{x}_{\mathrm{k}}$. Como resultado, uma sequência $f$ satisfaz uma fórmula do tipo, $\mathrm{Ix}_{1} \mathrm{x}_{2}{ }^{\text {ee }}$, que se lê , $\mathrm{x}_{1}$ está inclusa em $\mathrm{x}_{2}{ }^{\text {ee }}$, se, e somente se, a classe $f_{1}$ da sequência está inclusa na classe $f_{2}$ da mesma sequência. No caso de uma fórmula disjuntiva, o método se sugere a si mesmo: uma sequência a satisfaz se, e somente se, satisfaz ao menos um dos termos disjuntos. Mas a vantagem crucial desse método é a capacidade de conseguir, composionalmente, fornecer uma cláusula de satisfação para fórmulas com quantificadores.

Para facilitar a apreciação, tomemos a função predicativa „, $\mathrm{x}_{\mathrm{n}}$ é verde ${ }^{e e}$. No caso de uma fórmula universalmente quantificada em que a variável presa pelo quantificador é „, $\mathrm{x}_{\mathrm{n}}{ }^{e}$, uma sequência $f$ qualquer satisfaz $, \forall x_{\mathrm{n}}: \mathrm{x}_{\mathrm{n}}$ é verde ${ }^{\text {ee }}$, se e somente se toda sequência $f$ ' que difere de $f$ no máximo no k-ésima termo, também satisfaz , $\mathrm{x}_{\mathrm{n}}$ é verde ${ }^{\mathrm{e}}$. Isso significa que toda sequência que difere de $f$ no máximo no k-ésima lugar, ou seja, que difere na classe que ocupa esta posição, também satisfaz „, $\mathrm{x}_{\mathrm{n}}$ é verde ${ }^{\text {ee }}$ porque o objeto na k-ésima posição de $f$, , assim como o objeto na késima posição $f$, cai sob a função , , $\mathrm{x}_{\mathrm{n}}$ é verde ${ }^{e e}$ Por fim, para sentenças em que não há variáveis livres para serem satisfeitas, a definição em termos de satisfação tem por consequência que uma 
sentença ou é satisfeita por todas as sequências ou por nenhuma. Logo, para qualquer linguagem objeto para a qual se tem uma definição de verdade que cumpre a Convenção-T, uma sentença verdadeira é aquela satisfeita por todas as sequências. 


\section{CAPÍTULO III: A PARTE PROPOSITIVA DO PROJETO DE DAVIDSON E DESAFIOS POSTOS.}

\section{Introduzindo a Proposta.}

O método de introdução de significados como entidades não mostrou ter qualquer utilidade real em um projeto de fornecer uma teoria composicional do significado. Esta é a conclusão, como examinamos detalhadamente no capítulo I, à que chega Davidson em "Truth and Meaning”. E é tendo em perspectiva esta tese, que chamamos de conteúdo crítico do projeto, que devemos, então, olhar para a proposta de Davidson de que uma teoria composicional pode ser construída por meio do emprego de uma teoria axiomática da verdade de tipo tarskiana, i.e., que respeita a Convenção$\mathbf{T}^{59}$. Uma teoria recursiva, nesse sentido, adaptada para as línguas naturais, que empregada a noção de satisfação, de maneira a relacionar expressões da linguagem sob investigação a sequências de objetos via axiomas que estabelecem condições de satisfação para essas expressões ${ }^{60}$.

A transição para a parte propositiva do projeto em TM começa com uma síntese das catacterísticas gerais essenciais da proposta.

A única maneira que conheço de lidar com essa dificuldade é simples e radical. A ansiedade de que estejamos enredados no intensional emana do uso das palavras

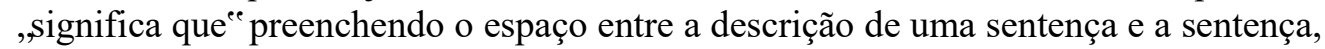
mas pode ser que o sucesso de nosso empreendimento não dependa do preenchimento, mas do que ele preenche. A teoria terá feito o seu trabalho se ela fornecer para toda sentença $s$ na linguagem sob estudo, uma sentença correspondente (a substituir , $p^{\text {ee }}$ ) que, de alguma maneira ainda a ser tornada clara, ,fornece o significado de $s^{\text {ee }}$. Um óbvio candidato é a própria sentença $s$, se a linguagem objeto estiver contida na metalinguagem; caso contrário, uma tradução de $s$ na metalinguagem. Como um último passa ousado, tentemos tratar a posição ocupada

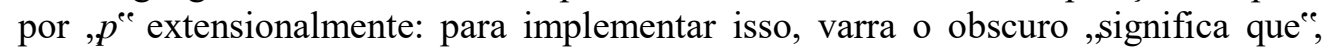
abasteça a sentença que substitui,$p^{\text {ee }}$ com um conectivo sentencial apropriado, e a descrição que substitui , ,"eom o seu próprio predicado. O resultado plausível é

(T) $s$ é $T$ se e somente se $p$

O que exigimos de uma teoria do significado para uma linguagem $L$ é que sem apelo a quaisquer (mais) noções semânticas ela imponha restrições suficientes sobre o predicado „é $T^{\mathrm{e}}$ de modo a acarretar todas as sentenças obtidas a partir do esquema

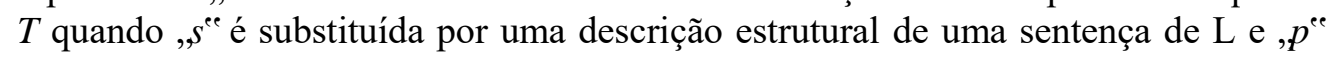
pela própria sentença. (Davidson 1990 [1967]: 23).

\footnotetext{
${ }^{59}$ Critério de adequação de uma teoria da verdade proposto por Tarski e examinado no capítulo II da presente tese.

${ }^{60}$ Em Tarski, como exibido no capítulo anterior, uma teoria da verdade para uma linguagem L assume a forma de uma definição explicita, com cláusulas de satisfação para os termos de L. Numa versão axiomática de uma teoria da verdade, uma vez que ela está construída não por meio de definições, está disponível para o teórico introduzir novos axiomas à medida que noças expressões ou classes de expressões de uma língua natural são incorporadas à teoria.
} 
Embora esta seja a passagem mais citada de "Truth and Meaning”, ela é talvez a principal fonte de interpretações equivocadas acerca do projeto. Tomado na maioria das vezes em isolado, removido do contexto maior do texto, em especial do conteúdo crítico que a antecede e que prepara a sua introdução (para não mencionar do contexto maior do conjunto dos textos programáticos), o fragmento acima muitas vezes é mobilizado como ilustração da tese de que Davidson intenta substituir uma teoria do significado por uma teoria da verdade, ou identificar esta com aquela ${ }^{61}$. Contudo, um exame detalhado do exerto à luz do contexto dos textos que conformam o projeto - e mesmo nos limitando a TM e TMLL - mostra que Davidson acredita que uma teoria axiomática e interpretativa da verdade pode ser posta a serviço de uma teoria do significado e não substituí-la.

Lembrem que no esquema da forma ,s significa (que) $p^{\text {ee }}$, embora tenhamos a ilusão de que capturamos o significado de , $s^{\text {ee }}$ se referindo ao seu significado via,,$p^{\mathrm{ee}}$, na verdade o que é crucial é que usamos na metalinguagem uma sentença que substui , $p^{\text {ee }}$ que traduz a sentença da linguagem

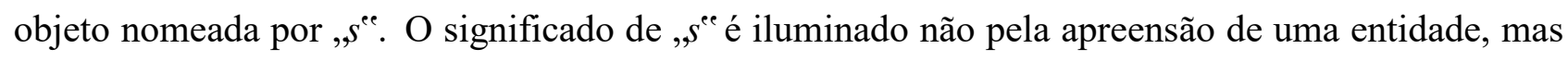
pelo uso de uma sentença $p$ que compreendemos e que traduz,,$s^{\text {ee }}$. Essa “dificuldade” embutida no esquema-M, uma vez que é a expressão ,significa (que) ${ }^{\text {ee }}$ - que parece criar um contexto intensional - a responsável por induzir a ilusão de utilidade da reificação, pode ser evitada por uma estratégia "radical": descartar o esquema-M. Mas notem que essa estratégia não implica um abandono do que é essencial no esquema-M, a saber, o emprego de uma sentença na metalinguagem que traduz uma sentença da linguagem objeto. Sem esse entendimento, é quase certo que o restante da passagem será mal interpretado. Essa característica essencial do esquema-M deve ser preservada na tarefa de fornecer uma teoria semântica composicional. E Davidson é claro quanto a isso na passagem, quando pontua que a "teoria terá feito o seu trabalho se ela fornecer para toda sentença $s$ na linguagem [...] uma sentença correspondente (a substituir , $p^{\text {ee }}$ ) que, de alguma maneira ainda a ser

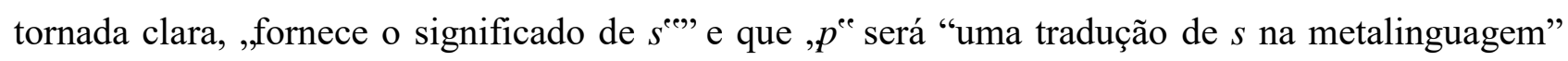
quando a linguagem objeto não está contida nela. Uma tarefa crucial para uma teoria do significado é justamente gerar os pares adequados de sentenças. O "sucesso [...] do empreendimento" de fornecer uma tradução não se assenta no tipo de "preechimento" do espaço entre , ,se e ,p que ocorre num esquema-M, isto é, a expressão intensional ,significa (que $)^{e e}$, mas em compreender , $p^{\text {ee }}$ e saber que,$p$ ' traduz,$s^{\text {ee }}{ }^{62}$

\footnotetext{
${ }^{61}$ Para interpretações que sustentam esta posição ou que a sugerem, ver Cummins 2002; Soames 1992 e Stich 1976. Mas talvez a interpretação mais equivocada seja a de Cummins, que chega ao ponto de concluir que Davidson reificaria condições de verdade e as condições de satistação atrituídas a cada expressão de uma língua L, tratando-as como entidades identificadas como os significados das sentenças e de suas partes.

${ }^{62}$ Como abordaremos na subseção sobre indexicais, em que o esquema-T será relativizado a parâmetros contextuais, a ideia de que o que aparece do lado direita da equivalência terá de ser flexibilizada.
} 
Mas o que Davidson intenta ao dizer que a sentença que substitui „,p "de alguma maneira ainda a ser tornada clara, ,fornece o significado de $s^{\text {eeen? }}$ Primeiramente, que , $p^{\text {ee }}$ na alternativa a ser proposta cumprirá o mesmo papel que desempenha no esquema-M, mas sem postular significados como entidades (uma estratégia que precisa ainda ser apresentada como viável no decorrer de TM). É essa mesma ideia que reaparece alguns parágrafos mais à frente quando Davidson menciona que sua teoria do significado termina não empregando significados: "meu uso livre da palavra „significado "e para o que chamo de teoria do significado afinal de contas acabou por não fazer uso de significados, quer de sentenças quer de palavras" (idem). Não usar significado aqui quer dizer empregar uma teoria que não associa às expressões e sentenças da linguagem sob estudo significados reificados. E de fato o uso da palavra "significado" é "livre" no sentido de que o projeto não intenta responder à pergunta “o que é significado?”, fornecer uma definição geral do termo ou, de partida, adotar uma tese sobre a natureza do significado. Esse não é o projeto semântico de Davidson. Com já é exposto em TMLL, o propósito é de perseguir uma teoria que descreva a dimensão composicional da interpretação das sentenças de uma língua, e empregar conceitos semânticos na caracterização desta habilidade linguística.

Ao colocar entre aspas "fornece o significado de $s$ " na argumentação acima, Davidson indica que há mais sobre o aspecto composicional do significado de uma sentença em uma língua $\mathrm{L}$ e que esse "mais" não é exaurido meramente substituindo , $p^{e e}$ pela própria sentença referida por ,,$^{\text {ee }}$ quando a linguagem objeto está contida na metalinguagem, ou uma tradução quando aquela não está contida nesta, o que é o caso das línguas naturais. E é aqui que entra "um último passa ousado": a proposta não se limita a descartar o esquema ,s significa (que) pe, preservando o mecanismo de tradução sem tratar , $p^{\text {ee }}$ como um termo referencial que denota uma entidade abstrata. Além disso, ela intenta exibir um aspecto substancial do significado das sentenças: a composicionalidade das suas condições de verdade. Isso porque substituir „,s significa p por „,s é verdadeiro em $\mathrm{L} \leftrightarrow p^{e e}$, consiste, para Davidson, em uma solução que, além de possibilitar emparelhar , , ${ }^{\text {ee }}$ com o uso de,$p^{\text {ee }}$ que a traduz e que evita colocar,$p^{\text {ee }}$ em uma posição intensional, assegura perseguir uma teoria que ilumina o papel das expressões de uma língua na conformação das suas condições de verdade.

O segundo parágrafo da passagem especifica que a teria do significado a ser esboçada, para ser adequada, deve obedecer a um critério similar ao do tipo estabelecido por Tarski como condição para que uma definição de um predicado de verdade para uma linguagem seja adequada. A demanda é que uma teoria do significado deve impor suficientes condições sobre um predicado de verdade para uma língua sob investigação de forma que para cada sentença da língua seja gerada uma instanciação do esquema-T, ou seja, um teorema, que interpreta a sentença, fornecendo suas 
condições de verdade. Davidson sustenta que uma teoria pode obedecer a esse critério sem o apelo a conceitos semânticas além dos necessários para implementar o mecanismo de geração composicional das sentenças-T. Essas noções semânticas são fundamentalmente os conceitos de referência, satisfação e tradução. Observem que em nenhum momento Davidson diz que uma teoria da verdade que satisfaz a convenção-T é uma teoria do significado. Ele apenas sustenta que uma teoria do significado para uma língua L exige que a teoria da verdade que emprega deve cumprir o critério. Contudo, no parágrafo subsequente, há um trecho que, isolado, pode sugerir a ideia de que a proposta de Davidson seria de substituir uma teoria do significado por uma teoria da verdade.

\begin{abstract}
Quaisquer dois predicados satisfazendo esta condição [a Convenção-T] têm a mesma extensão; então se a metalinguagem é rica o suficiente nada impede de colocar o que estou chamando de uma teoria do significado na forma de uma definição explícita de um predicado 'é $T$ '. ${ }^{63}$ Mas quer definido explicitamente quer caracterizado recursivamente, está claro que as sentenças às quais o predicado ,é Tec se aplica serão somente as sentenças de L, pois a condição que colocamos sobre teorias satisfatórias do significado é em essência a Convenção-T de Tarki, que testa a adequação de uma de finição semântica e formal de verdade (Davidson 1990 [1967]: 23).
\end{abstract}

Davidson reconhece no texto "Reply to Foster" (1974) - debate que examinaremos no capítulo V que pode haver partes de TM em que ele não foi feliz em explicitar "exatamente qual é a relação entre uma teoria da verdade e uma teoria do significado" (Davidson 1990 [1974): 171). Por exemplo, no trecho em itálico acima Davidson parece sugerir que tudo o que pode ser dito em uma teoria do significado pode ser circunscrito à forma puramente extensional de uma definição de verdade à lá Tarski. Mas como elaboraremos no momento oportuno, o projeto de Davidson não defende que o emprego de teoria da verdade na elaboração de uma teoria do significado consiste na postura de que uma teoria da verdade estabelece tudo o que é suficiente saber para que alguém a use para interpretar uma língua L. Uma teoria da verdade pode ser construída de forma puramente extensional, mas o que devemos saber acerca da teoria que nos permite tratá-la como interpretativa precisará recorrer a uma linguagem intensional. E é esse conjunto, uma teoria da verdade que respeita a Convenção-T e o conhecimento da teoria que, na perspectiva de Davidson, conformará a teoria do significado. Tendo isso em mente, a leitura mais adequada do trecho não tão claro é que, empregando uma teoria da verdade extensional que cumpre a Convenção-T, e que, portanto, instancia o esquema-T mediante sentenças-T interpretativas, podemos cumprir o mesmo objetivo de

\footnotetext{
${ }^{63}$ A parte em itálico é nossa.
} 
uma teoria da forma ,s significa (que) pe, pois ela pode fornecer do mesmo modo o significado das sentenças de uma linguagem objeto.

Mas mesmo em "Truth and Meaning” Davidson se preocupa em esclarecer que o objetivo de uma teoria composicional do significado deve ser de fornecer uma descrição das línguas naturais iluminando as propriedades semânticas composicionais das suas expressões. A intenção é construir uma teoria que capture a natureza composicional das estruturas das sentenças de uma língua L, e não de prescrever estruturas. Nas palavras de Davidson, “[...] a tarefa de uma teoria do significado como eu a concebo não é mudar, aperfeiçoar, ou reformar uma língua, mas a descrever e entender" (Davidson 1990 [1967]: 29). E recupera a mesma ideia, em “The Method of Truth in Metaphysics", texto de $1977^{64}$, no contexto de um debate sobre a eficácia do emprego da lógica de predicados para capturar estruturas de uma língua natural: “[...] uma vez que não estou interessado em aperfeiçoar a língua natural, mas em compreendê-la, eu vejo as linguagens formais ou notações canônicas como mecanismos para explorar a estrutura da língua natural" (Davidson 1990[1977]: 202). ${ }^{65}$ Aqui Davidson se preocupa fundamentalmente em se distanciar da tradição, que remonta novamente a Frege, de olhar para as línguas naturais com o intuito de identificar suas "imperfeições", de maneira a construir uma linguagem purgada dos defeitos da linguagem coloquial.

Há um conjunto significativo, entretando, de problemas que colocam dificuldades para o otimismo de que uma teoria do tipo esboçada possa ser fornecida para as línguas naturais. Considero que existem aqui duas classes de questões a serem enfrendadas pelo projeto davidsoniano. A primeira classe emerge diretamente da forma do projeto: o emprego de uma teoria da verdade inspirada em Taski na construção de uma teoria composicional do significado. Para grande parte desses problemas já nos chama a atenção Tarski, como expus no capítulo II, mas outros não menos importantes também surgem. Essa classe pode ser lida como a dos problemas que colocam em questão o próprio fundamento do projeto, pois dizem respeito diretamente às chances sérias de que uma teoria da verdade à lá Tarski possa ser posta a serviço de uma teoria semântica para as línguas naturais. Tais problemas são: (i) uma língua natural, em função de possuir predicados semânticos, em especial o predicado de verdade, engendra paradoxos semânticos uma vez que tentamos definir um predicado de verdade para ela. A antinomia do mentiroso emerge assim que tentamos aplicar um predicado de verdade a sentenças que contém o próprio predicado.

\footnotetext{
64 “The Method of Truth in Metaphysics" foi publicado pela primeira vez em Midwest Studies in Philosophy, 2: Studies in Philosophy of Language, The University of Minnesota, Morris, 1977.

${ }^{65}$ Examinaremos como Davidson concebe o papel de notações canônicas na descrição das línguas naturais e sua relação com a forma semântica das expressões, quando tratarmos da semântica de eventos proposta por Davidson para tratar dos advérbios, sentenças de ação e sentenças causais. Neste contexto ficará evidente como que Davidson compreende o papel de uma teoria da verdade na exposição da forma lógica das sentenças e da ontologia das línguas naturais.
} 
Esse fato de antemão inviabilizaria a possibilidade de que uma definição de verdade para uma língua L obedeça a Convenção-T; (ii) as expressões de uma língua natural são subespecificadas, i.e., não haveria critérios claros de determinação sintática do que é uma sentença em língua natural; logo, não se pode delimitar formalmente a classe das expressões às quais o predicado de verdade se aplicaria; (iii) muitas expressões e sentenças de uma língua natural são ambíguas, e seriam ilustrações do aspecto impreciso do significado em língua natural; (i), (ii) e (iii) evidenciariam, desse modo, que as "línguas naturais são muito confusas e amorfas para permitir uma aplicação direta de metodos formais"(Davidson 1990[1967]: 28). Do que se concluiria que, ao invés de descrever a estrutura semântica de uma língua natural, acaba-se muito mais prescrevendo estruturas, o que coloca em dúvida a própria possibilidade de fornecer uma teoria interpretativa da verdade para uma língua natural. A segunda classe de problemas diz respeito ao comportamento semântico de expressões de uma língua natural e a como dar um tratamento satisfatório dessas expressões que descreva adequadamento o papel que desempenham nas sentenças em que ocorrem, incorporandoas a uma teoria semântica. A questão toda é de como capturar a semântica dessas expressões via axiomas que estabelecam as suas condições de satisfação, i.e., as características que possuem que contribuem para as condições de verdade de todas as sentenças nas quais ocorrem e das sentenças que se inferem a partir delas. Aqui o desafio é de ampliação do fragmento de uma língua natural que pode ser capturado pelo método formal proposto. Tal ampliação demanda, como veremos, modificações substanciais na forma da teoria. Por exemplo, para incorporar expressões indexicais será necessário introduzir variáveis no esquema-T que capturam parâmetros contextuais, de modo a relativizar a verdade das sentenças às situações de uso. Quanto maior o fragmento maior o escopo explicativo da teoria, e, presumivelmente, maior a sua força como uma semântica empírica. Entre tais fragmentos das línguas naturais, daremos destaque aos seguintes: (i) pronomes pessoais e demonstrativos; (ii) quantificadores; (iii), expressões adverbiais e (iv) sentenças com verbos de ação e que estabelecem relações causais

Ambas as classes de problemas estão relacionadas e se complementam, mas nada impõe de antemão uma hierarquia na ordem de tentativas de tratamento dos problemas que as constituem. Ainda que certos desafios possam remeter mais diretamente aos fundamentos da teoria, e ao cabo demandem uma resposta séria sem a qual o projeto pode ser posto em dúvida, o seu adiamento não impede que se formulem soluções para os outros problemas. Meu propósito neste capítulo não é de mostrar que há uma solução para cada um dos problemas mencionados, mas antes de examinar o caráter desses problemas, abordar soluções apresentadas por Davidson, comentadores e críticos, indicar limites de algumas dessas soluções, e propor algumas saídas. Intenta-se, dito isso, expor e examinar o rico mosaico de questões que o projeto de Davidson motiva e defender que, ainda que 
haja pontos controversos que ainda exijam explicações e teses mais convincentes, na sua totalidade, o projeto têm se apresentado bastante promissor como uma teoria composicional para extensos fragmentos das línguas naturais e cumprido em grande medida o seu propósito. A sua força explicativa e preditiva, como veremos, não somente possibilitou a incorporação em uma teoria sistemática de vastos fragmentos das línguas naturais, mas também iluminou, por meio da caracterização das estruturas composionais das sentenças, i.e., por meio da especificação das suas formas semânticas, a ontologia que subjaz nas línguas naturais. Dividirei este capítulo em dua seções. Na primeira seção me concentrarei na segunda classe de problemas, a saber, os desafios colocados pelo comportamento de determinadas expressões linguísticas nas línguas naturais. $\mathrm{Na}$ segunda seção, examinarei as objeções levantadas por Tarski contra a viabilidade de se estender para as línguas naturais o seu método formal de definição de uma predicado de verdade.

\section{Capturando o comportamento semântico de algumas expressões linguísticas.}

\subsection{Elementos sensíveis ao contexto e revisão da Convenção-T.}

As sentenças das línguas naturais são realizadas em situações concretas de uso, e, ao contrário das sentenças de linguagens formais, sua verdade ou falsidade depende na maioria dos casos do contexto no qual são enunciadas. A sentença, por exemplo, „Eu estou com sono ${ }^{\text {ee }}$, pode ser verdadeira quando enunciada por um falante e falsa quando enunciada por outro. E mesmo mudar o seu valor de verdade quando dita por um mesmo falante em momentos distintos. As condições de

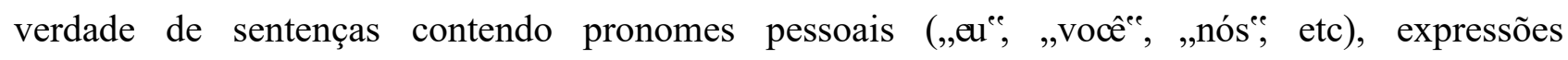

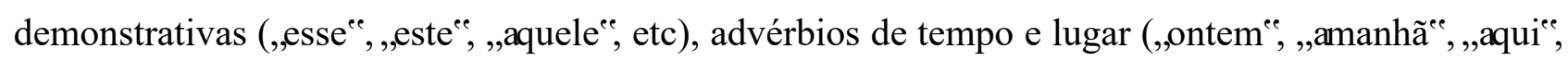
etc) são determinadas em relação a aspectos contextuais. Tais expressões, nomeadas de dêiticas ${ }^{66}$, que conformam uma subclasse do que se convencionou chamar de elementos indexicais, variam constantemente a sua referência de contexto de uso para contexto de uso. Mas evidentemente que essa variação não é arbitrária. É possível identificar aspectos ou parâmetros dos contextos que operam sistematicamente na determinação da referência de distintos termos indexicais. ${ }^{67}$ Por exemplo, o pronome pessoal „eu se referirá ao falante, ou seja, a quem enuncia uma sentença que contém tal pronome. E se tratarmos o tempo expresso pelos verbos como expressões demonstrativas, uma sentença como ,eu limpei a casa ${ }^{\text {ee }}$ remete a uma ação anterior ao momento de fala, de maneira que as condições de verdade da sentença estabelecem uma relação entre o momento em que a sentença é enunciada e uma ação que antecede este momento. O comportamento

\footnotetext{
${ }^{66}$ Do grego deiktikós: demonstrativo.

${ }^{67}$ Tem-se por referência aqui a taxonomia dos indexicais proposta por Kaplan em "On The Logic of Demonstratives", in Journal of Philosophical Logic, 8, 1979: 81-98.
} 
dos termos dêiticos, e dos indexicais em geral, indica que a maneira adequada de descrever o papel semântico que cumprem nas sentenças é de associar a eles regras que exibem como que a variação da sua referência está ancorada em parâmetros contextuais, i.e., em parâmetros extralinguísticos relevantes para a especificação do significado desses termos. Nesse sentido, uma teoria semântica adequada deve ser capaz de capturar essas propriedades contextuais das expressões indexicais, e integrá-las aos axiomas que estabelecem as condições de satisfação desses termos. Isso porque, presumivelmente, uma teoria que representa as condições de verdade das sentenças de uma língua natural como sendo indiferente ao contexto, não simplesmente fornece uma especificação bastante parcial das condições de verdade de sentenças em uso, mas pode representar erradamente as condições de verdade de uma sentença. Tomemos a seguinte sentença-T da sentença em Inglês „I am a great soccer playere:

$(\alpha)$. „I am a great soccer player"é verdadeira em Inglês $\leftrightarrow$ Eu sou um grande jogador de futebol.

Se eu empregar a sentença-T $(\alpha)$ para interpretar um falante que enuncia „I Iam a great soccer player nada impede que eu o interprete como atribuindo a mim a propriedade de ser um grande jogador. Isso mostra que, para representar adequadamente as condições de verdade da sentença em questão, é preciso relativizar o referente de , $\mathrm{I}^{\mathrm{ee}}$ ao falante e capturar a relativização ao tempo presente que o verbo na sentença indica.

$\mathrm{O}$ fato de as condições de verdade das sentenças das línguas naturais serem relativizadas a contextos de uso coloca, portanto, uma necessidade de modificar uma teoria da verdade à lá Tarski para que ela seja aplica às línguas naturais. Como demonstrado no capítulo II, o predicado de verdade se aplica diretamente a sentenças de uma linguagem L, sendo concebido, assim, como um predicado de sentenças. Não há, no método exposto por Tarski, ao menos na sua aplicação ao cálculo das classes, a necessidade de acomodar elementos linguísticos sensíveis ao contexto. Contudo, modificações precisam ser realizadas num predicado de verdade para que ele possa, em princípio, vir a ser aplicado a uma línguagem com expressões dêiticas. Aqui emerge a pergunta: quais modificações são necessárias e quais os seus efeitos sobre a forma que a teoria assume e suas condições de adequação?

Davidson, já em TMLL ${ }^{68}$, sublinha que a viabilidade de uma semântica formal das línguas naturais depende da capacidade de incorporar na sua descrição das sentenças variáveis para falante,

\footnotetext{
${ }^{68}$ Ver a primeira seção do capítulo I.
} 
tempo e circunstância, pois uma sentença é enunciada por um falante, em um período de tempo e em uma situação particular. Em "Semantics for Natural Languages” Davidson introduz este desafio, esta "mosca na sopa" (Davidson 1990[1967]: 33), remetendo à necessidade de rever a Convenção$\mathrm{T}$ :

Uma teoria da verdade para uma língua natural deve ter em conta o fato de que muitas sentenças variam de valor de verdade dependendo do momento em que elas são faladas, do falante, e até, talvez, da audiência. Podemos acomodar esse fenômeno tanto declarando que são enunciados particulares ou atos de fala, e não sentenças, que possuem valor de verdade, ou tornando verdade uma relação que se estabelece entre uma sentença, um falante, e um tempo.

Assim, acomodar os elementos indexicais, ou demonstrativos, consiste em aceitar uma mudança conceitual radical no modo em que verdade é definida, como será apreciado pela reflexão sobre como a Convenção-T deve ser revisada para tornar verdade sensível ao contexto. Mas a mudança não precisa significar um afastamento da formalidade (Davidson 1990[1970]: 58).

Um tema crucial é introduzido acima e pede que se detenha nele antes de adentrar na proposta de Davidson de revisão do esquema-T e, por conseguinte, da Convenção-T. Ao se estabelecer em uma teoria o vínculo entre sentença, falante e contexto, imediatamente emerge a questão de qual entidade de fato passa a ser a portadora de valor de verdade. Na comunicação linguística real, falantes expressam, de forma falada ou escrita, realizações concretas de sentenças. Tais atos linguísticos são indissociáveis da situação comunicativa em que ocorrem. E se as condições de verdade são determinadas com referência a falantes e circunstâncias, o adequado é relacionar verdade aos falantes na ação comunicativa. Do que se depreende que uma maneira possível de se acomodar este fenômeno na definição de verdade para uma língua L é aplicar o predicado de verdade a enunciados (ou atos de fala) sem referência a sentenças, i.e., quantificando sobre enunciados. Mas o papel desempenhado pela realização concreta das sentenças pode ser codificado quantificando sobre variáveis sentenciais e estabelendo uma relação entre falante, tempo e circunstância. E é essa segunda solução que Davidson advoga e e sistematiza. Concentremo-nos nela. ${ }^{69}$

\footnotetext{
${ }^{69}$ Embora Davidson não elucide o que motiva essa preferência, creio identificar uma razão. Ela me parece originar-se do fato de que o objetivo é de fornecer uma teoria que não se restringe a uma lista de sentenças-T, mas uma teoria axiomática, em que as sentenças-T são derivadas a partir de axiomas que estabelecem condições de satisfação para cada expressão básica de uma língua e que exibem a sua contribuição em potencial para o significado de qualquer sentença na qual possa ocorrer. Uma aplicação do predicado de verdade diretamente a enunciados acaba sugerindo as seguintes questões, que não são nada fáceis de serem respondidas, referentes à composicionalidade de enunciados: como seria modelar, em uma teoria da verdade, as unidades constitutivas de um enunciado? Se um enunciado (ou ato de fala) for uma unidade composta, o que seriam essas partes que conformam o enunciado? Entendo que Davidson parece ver a sua solução como uma estratégia que captura as informações contextuais relevantes para as condições de verdade das sentenças, com a vantagem de evitar ter de se debruçar sobre questões acerca da natureza dos enunciados e sua composicionalidade.
} 
$\mathrm{Na}$ estratégia de Davidson, quantificando sobre falante e tempo, e introduzindo essas variáveis para parâmetros contextuais nos axiomas que atribuem condições de satisfação aos termos primitivos, consegue-se determinar, composicionalmente, as condições de verdade por meio de sentenças-T que definem o predicado de verdade como uma relação triádica. Sob esta revisão, o esquema-T, então, assume a seguinte forma:

( $\beta) .(\forall \mathrm{r} \forall \mathrm{t})\left(s\right.$ é verdadeira em $\left.\mathrm{L}_{(\mathrm{r}, \mathrm{t})} \leftrightarrow p\right)$

onde ,re é uma variável para falante e ,t" para tempo. $(\beta)$ deve ser lida da seguinte forma: para todo falante $\mathrm{r}$ e tempo t, a sentença $s$ é verdadeira em uma língua L como (potencialmente) falada por $\mathrm{r}$ no tempo $t$ se, e somente se, $p$. Logo, dada a sentença „Eu sou atleta ${ }^{\text {'ee }}$, tem-se

$\left(\beta^{e e}\right)$,Eu sou atletae é verdadeira em Português como potencialmente falada por $\mathrm{r}$ no tempo $\mathrm{t}$ se, e somente se, ré atleta no tempo t. ${ }^{70}$

É importante notar que quando se instancia $(\beta)$ para uma sentença particular, como em $\left(\beta^{\text {ee }}\right)$, as variáveis para falante e tempo também aparecem no lado direito da equivalência; isso se deve ao requerimento de que a tradução (ou interpretação) adequada desta sentença deve especificar os aspectos contextuais do seu significado. Desse modo, sob esta descrição, e reescrevendo a sentença$\mathrm{T}$ de $\left(\beta^{\mathrm{ee}}\right)$ de forma mais formal, temos:

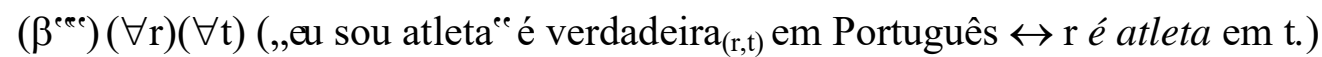

Mas para gerar $\left(\beta^{\text {cee }}\right)$ devo empregar axiomas para o pronome ,eu e a expressão predicativa „x é atleta $^{e e}$ que especificam suas condições de referência e satisfação, respectivamente. Uma vez que o pronome „eul se refere somente relativo a ocasiões de uso, um axioma para ele deve quantificar universalmente sobre falante e tempo. Para capturar o papel referencial deste pronome, i.e., de que „euce se refere à pessoa que o usa, o axioma deve exibir esse papel na forma de uma regra. Tal é o caso abaixo:

Ax1. $(\forall \mathrm{r})(\forall \mathrm{t})\left(\operatorname{Ref}\left(\right.\right.$ 'eu $\left.\left.^{\mathrm{ee}}, r, t\right)=\mathrm{r}\right)$

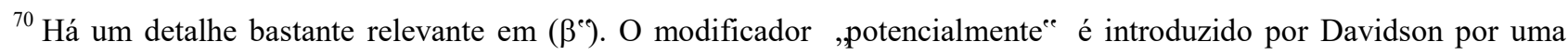
razão que não poderia ser negligenciada. Uma versão de $\left(\beta^{\text {co}}\right)$ em que o modificador está ausente resulta numa sentença$\mathrm{T}$ falsa se houver uma caso em que alguém é um atleta, mas nunca enunciou "Eu sou um atleta".
} 
Já um axioma para ,x é atleta ${ }^{e e}$ demanda, para sermos fiéis ao método de Tarski, que se empregue a noção de sequencias de objetos satisfazendo sentenças abertas.

\section{Ax2. $(\forall \mathrm{r})(\forall \mathrm{t})(\forall f)\left(f\right.$ satisfaz $_{(\mathrm{s}, \mathrm{t})}, \mathrm{x}_{k}$ é atletae $\leftrightarrow f\left(\mathrm{x}_{k}\right)$ é atleta em $\left.\mathrm{t}\right)$}

Onde $f$ é uma variável para sequência de objetos, e $\mathrm{x}_{k}$ a variável com indice $k$ de uma função sentencial. Nessa estratégia, em vez de se falar de um objeto safisfazendo a função sentencial, ao associar índices numéricos às variáveis das sentenças abertas, fala-se em sequências de objetos satisfazendo as expressões de uma língua. Nesse sentido, deve-se ler ,f( $\left.\mathrm{x}_{k}\right)$ é atleta em tec como: o $k$ ésimo objeto na sequência $f$ é atleta em t. De forma mais detalhada, uma sequência satisfaz , , $\mathrm{x}_{k}$ é atleta $^{e e}$ somente quando o objeto que ocupa a posição, na sequência, indicada pelo índice numérico subescrito na variável $x_{k}$ está na extensão da função sentencial em questão no tempo t. ${ }^{71}$ Notem que o axioma Ax1 de referência e a relação de satisfação no axioma Ax2 estão ambas relativizadas a falante e tempo. Com a aplicação dessas duas cláusulas podemos gerar as condições de verdade (acomodando parametros contextuais) de ,eu sou atleta ${ }^{e e}$ instanciando em $\left(\beta^{\text {ee }}\right)$ o esquema-T ilustrado em $(\beta) .^{72}$

Tomemos agora o pronome demonstrativo ,aquelee. Um papel bastante evidente desta expressão em Português é que ela se refere ao objeto ou evento que o falante demonstra quando a emprega. Logo, o axioma para ,aquele ${ }^{e e}$ deve capturar essa função. Uma primeira alternativa de axioma seria:

Ax3. $(\forall \mathrm{r})(\forall \mathrm{t})\left(\operatorname{Ref}\left(\right.\right.$ 'aquele $\left.^{\mathrm{ee}}, r, t\right)=\mathrm{o}$ objeto demonstrado por $\mathrm{r}$ em $\left.\mathrm{t}\right)$

onde a descrição definida do lado direito da identidade garante a unicidade do objeto demonstrado. Contudo, justamente o uso da descrição em Ax3 pode apresentar algumas dificuldades. Embora pronomes demonstrativos sejam expressões usadas rigidamente, a descrição definida ,o objeto demonstrado por $\mathrm{r}$ em tee $\mathrm{em}$ Ax3 não é rígida. Esse fato pode impor dificuldades para interpretar „aquele ce corretamente em contextos modais, se empregarmos Ax3. Uma solução à disposição é transformar a descrição do lado direito em uma descrição rígida via introdução da expressão „de fato ${ }^{e e}$ :

\footnotetext{
${ }^{71}$ Para uma exposição detalhada dos conceitos de satisfação e sequências de objetos, consultar o capítulo II.

${ }^{72}$ Em verdade, a aplicação dessas cláusulas mais regras de inferência.
} 


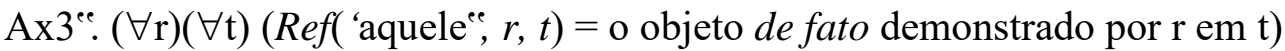

Mas Ax3 $3^{e e}$, embora possa evitar complicações em contextos modais, parece criar outro problema. Constantemente usamos expressões como, ,aquele ee em um tempo $t$ sem que estejamos necessariamente demonstrando um objeto à nossa frente. Se interpretarmos ,aquele ${ }^{\text {ee }}$ como Ax3 sugere, sentenças em tais situações serão sempre falsas. Em Lepore \& Ludwig (2009) é elaborada uma proposta que parece evitar isso. A ideia é de condicionalizar sobre um objeto demonstrado em um tempo. O axima proposto é o seguinte:

$$
\begin{gathered}
\mathrm{Ax}^{\text {cee }} .(\forall \mathrm{r})(\forall \mathrm{t})(\forall \mathrm{x})(\mathrm{x}=\mathrm{o} \text { objeto demonstrado por } \mathrm{r} \text { em } \mathrm{t} \text { usando, aquele } \\
t)=\mathrm{x})
\end{gathered}
$$

Há uma lição essencial a ser depreendida das revisões ilustradas acima do axioma para o demonstrativo ,aquele ${ }^{e e}$. As elaborações em uma teoria da verdade de axiomas que fornecem as condições de referência e satisfação relativas a falante e tempo das expressões de uma língua natural L devem ser testadas em relação aos seus possíveis usos por um falante na língua. Isso implica que quanto mais situações possíveis de emprego de uma expressão são contempladas na forma do axioma, maior a sua força preditiva, e, portanto, maior a sua adequação no sentido de iluminar a contibuição composicional da expressão para as condições de verdade das sentenças em que ela aparece. Por outro lado, quanto menor a cobertura por um axioma de possíveis situações de emprego de uma expressão, mais subespecificada será a descrição do seu papel composicional, e, consequentemente, mais parcial a exibição, se não incorreta, das condições de verdade das sentenças de que a expressão participa.

Notem que o propósito aqui ao acomodar a relativizão do predicado de verdade a ocasiões de uso consiste em avaliar a verdade de uma sentença de uma língua L em relação à sua interpretação. Isso é implementado mediante o emprego de parâmetros contextuais - falante e tempo - como inputs das regras exibidas nos axiomas que apresentam a contribuição composicional de termos sensíveis ao contexto para as condições de verdade das sentenças. ${ }^{73}$ Relativizando a falante e tempo, o lado direito da equivalência na sentença-T deve expressar o que a sentença descrita no lado esquerdo expressaria como usada por um falante em um tempo determinado. Nesse sentido, fornecer o significado consiste em interpretar uma sentença relativa ao contexto, i.e., interpretá-la

\footnotetext{
${ }^{73}$ Outros aspectos do contexto podem, se for necessário, ser incluídos na atribuição de condições de satisfação para as expressões de uma língua, tal como uma variável para localização. Mas acreditamos que falante e tempo foram suficientes para ilustrar por meio de regras o papel que o contexto de uso cumpre na especificação do significado dos termos exemplificados nesta subseção.
} 
como se fosse enunciada. O emprego de variáveis contextuais para falante e tempo nos axiomas de satisfação tem por propósito modelar, na forma de regras de uso, a contribuição do contexto para o que palavras e sentenças significam não meramente em cada realização particular efetiva, mas em cada uso em potencial.

A introdução de parâmetros contextuais pode levantar a questão sobre a distinção entre o significado das palavras e sentenças e o que os falantes intentam ao usá-las. Mas uma posição a ser discernida aqui é que, sob a abordagem proposta, o fato de o significado de uma sentença , se $^{\text {ser }}$

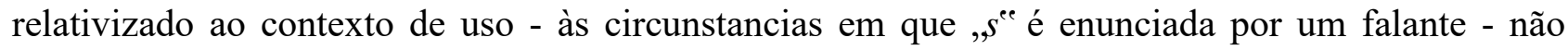
implica uma identificação do seu significado com a intenção com que ela é proferida, ou seja, com o que é para um falante significar algo ao enunciar uma sentença. O que um falante intenta transmitir para a sua audiência ao enunciar uma sentença, os efeitos que espera provocar, etc., estão para além do que o projeto vislumbra capturar. Em verdade, o projeto se apóia na pressuposição de que há um significado "literal" das sentenças que pode ser capturado independentemente das intenções e finalidades dos falantes. Davidson defende que ambas as noções de significado "são relativas às circunstâncias da performance [...]” (Davidson 1990[1969]: 46), mas no caso do significado "literal”, "abstraímos as intenções extra-linguísticas do falante”. Essa distinção pode ser ilustrada com um caso simples. Imagine a seguinte situação: um falante profere „Hoje é Sábado ${ }^{\text {ee }} \mathrm{em}$ uma conversação em que ele tem a intenção de, por meio deste ato linguístico, lembrar sua audiência, que neste caso são seus dois amigos de festa, que sábado é o dia de sair à noite. Neste exemplo, as condições de verdade da sentença e as intenções do falante são apreendidas pela audiência em relação ao contexto em que o falante profere a sentença. Mas a teoria se circunscreve a especificar as condições de verdade da sentença, a saber, que „„Hojé é sábado“é verdadeira se, e somente, proferida por um falante no sétimo dia da semana ${ }^{e e}$; ou seja, se for sábado no momento em que o falante enuncia a sentença. Do ponto de vista da teoria advogada, portanto, na produção dos enunciados, ainda que haja outros significados (intenção do falante, metafórico, idiomático, etc), está-se interessado "não no que a pessoa significou ao enunciar a sentença, mas o que a sentença, tal como enunciada, significou" (idem). Nesse sentido, ao adotar como foco de investigação o significado das sentenças expressas por um falante, o projeto davidsoniano induz uma distinção entre significado da sentença e a intenção do falante ao expressar a sentença ${ }^{74}$.

Essa revisão necessária - se pretendermos que o método possa representar a estrutura das disposições dos falantes em falar e compreender o significado das sentenças - demanda, por seu turno, uma modificação do requerimento de adequação proposto por Tarski, i.e., a Convenção-T.

\footnotetext{
${ }^{74} \mathrm{O}$ que não quer dizer, evidentemente, que a intenção do falante muitas vezes não coincida com os significados das sentenças.
} 
Lembrem, como exibido no capítulo II, que o critério em Tarski é estabelecido para linguagens formalizadas e insensíveis ao contexto. A Convenção-T para tais linguagens pode ser expresssa da sequinte forma:

Convenção-T. Uma teoria da verdade formalmente correta para uma linguagem objeto será chamada de uma teoria adequada se ela tiver como consequência todas as

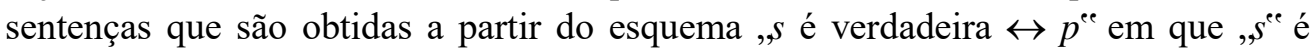
substituída por uma descrição estrutural de uma sentença da linguagem objeto e , $p^{\text {ee }}$ por uma tradução de , $s^{\text {ee }}$ na metalinguagem.

A Convenção-T exige que uma teoria tenha entre seus teoremas todas as sentenças-T que instanciam o esquema-T, ou seja, que fornecem uma descrição de uma sentença da linguagem objeto e uma tradução na metalinguagem da sentença descrita. Uma teoria que obedece a esse critério de adequação conterá, então, sentenças-T que fornecem as condições de verdade das sentenças da linguagem objeto e traduções delas. Nesse sentido, esses teoremas especificam os significados das sentenças. Pode-se dizer, por isso, que uma instanciação do esquema-T implicará a verdade de uma sentença-M, pois se o que substitui,$p^{\text {ee }}$ em,$s$ é verdadeiro em $\mathrm{L} \leftrightarrow p^{\text {ee }}$ traduz,$s^{\text {ee }}$, então,,s significa $\mathrm{p}^{\text {ee }}$

Uma construção do requerimento de adequação para teorias cuja linguagem objeto é sensível ao contexto, em vista do que já abordamos nesta seção, sugere a si mesma. Deve-se fornecer um critério cuja revisão consiste em relativizar o predicado de verdade a falante e tempo. O critério pode ser exposto da seguinte maneira:

Convenção- $\mathbf{T}_{\mathbf{r}}$. Uma teoria da verdade formalmente correta para uma linguagem objeto sensível ao contexto será chamada de uma teoria adequada se ela tiver como consequência todas as sentenças que são obtidas a partir do esquema ,s é verdadeira expressa por um falante $\mathrm{r}$ num tempo $\mathrm{t} \leftrightarrow p^{\text {ee }}$ em que ,se é substituída por uma descrição estrutural de uma sentença da linguagem objeto e , $p$ "e por uma sentença da metalinguagem que interpreta, ${ }^{\text {ee }}$ como usada por um falante $\mathrm{r}$ em um tempo $\mathrm{t}$.

Nesta versão para linguagens sensíveis ao contexto foram introduzidas variáveis para falante e tempo no esquema-T. Também a relativização ao contexto indica que as noções de tradução e sinonímia deixam de ter uma "aplicação precisa", pois a idéia agora é de que as sentenças da metalinguagem que substituem,$p^{\text {ee }}$ devem interpretar as sentenças da linguagem objeto como usadas por um falante em um tempo t. Sob esta forma, a noção de tradução na metalinguagem das expressões e sentenças da linguagem objeto, por assim dizer, é flexibilizada, pois o que se almeja é fornecer o significado das sentenças relativas a situações de uso. Tarski mostrou como que em uma teoria-T adequada para uma linguagem formalizada e insensível ao contexto tudo o que aparece do 
lado direito da equivalência é uma tradução da sentença descrita no lado esquerdo quando a metalinguagem não contém a linguagem objeto, e a própria sentença quando a linguagem objeto está contida na metalinguagem. O que significa que a sentença-T caracteriza verdade para uma dada sentença apenas com os recursos disponíveis na própria sentença. Todavia, o mesmo resultado não pode ser transposto para uma linguagem sensível ao contexto, uma vez que a relativização a parâmetros contextuais requer que as condições de verdade de uma sentença não sejam determinadas apenas via uma tradução, mas com referência a esses parâmetros que extrapolam a própria sentença. Em “The Method of Truth in Mephysics”, Davidson argumenta:

Uma teoria da verdade para uma língua natural deve relativizar a verdade de uma sentença a circunstâncias do enunciado, e quando isso é feito uma sentença-T não mais traduzirá a sentença descrita, nem será possível evitar o uso de conceitos que são talvez semânticos, ao fornecer as condições de verdade de uma sentença com termos indexicais. Mais importante, a noção de tradução, que pode ser tornada precisa para linguagens artificias sobre as quais interpretações são impostas por decreto, não tem aplicação precisa, ou nem mesmo clara, para as línguas naturais (Davidson 1990 [1977]: 204).

No caso de sentenças-T relativizadas ao contexto de uso das sentenças de uma linguagem objeto, o intento é justamente de interpretar as sentenças nas circunstâncias em que são enunciadas. E para tal não é suficiente olhar tão somente para a sua forma e fornecer uma sentença correspondente que se postula como sendo sinônima dela. Do ponto de vista do emprego de uma teoria da verdade para as línguas naturais, o propósito é de, por meio da noção de verdade, "lançar luz sobre significado, interpretação e tradução" (idem), e não o contrário. O que aparece do lado direito do bicondicional deve "traduzir" uma sentença relativa a falante e tempo. No caso de uma linguagem formalizada e interpretada, o conceito de tradução é preciso porque não requer mais do que a postulação de que uma expressão $x$ servirá de tradução para uma expressão $y$ cujo significado já está de antemão especificado. $^{75}$

\footnotetext{
${ }^{75}$ Davidson, nesse sentido, intenta inverter a perspectiva de Tarski. Enquanto este, preocupado em definir verdade para linguagens formalizadas, pressupõe os conceitos de sinonímia e tradução, Davidson, em contrapartida, perseguirá, introduzindo o método do intérprete radical, iluminar esses conceitos assumindo uma compreensão prévia do conceito de verdade. Essa inversão ocorre em parte por causa da própria natureza das linguas naturais, mas em parte também porque o objetivo é de construir uma teoria do significado, e não uma teoria da verdade. O que o método do intérprete racial intenta mostrar é que armados com uma teoria da verdade informada empiricamente, e relativizada a parâmetros contextuais, "podemos chegar a algo como significado a partir de verdade" (2001: 74-75). Ainda que o papel do intérprete radical na semântica de Davidson seja um tema que, para ser examinado apropriadamente, demandaria uma outra tese, na última seção do capítulo $\mathrm{V}$, abordarei panoramicamente o tema. Indicarei, com isso, que para realizar uma investigação mais completa do projeto faz-se necessário incluir o intérprete radical, assim como espero mostrar que a separação que Lepore \& Ludwig entre a semântica formal propriamente dita e o método do intérprete radical acaba comprometendo alguns aspectos cruciais da semântica neo-davidsoniana que propõem.
} 
A relativização das sentenças-T também força o emprego de variáveis para falante e tempo no lado direito do bicondicional, ao contrário do que ocorre no método de Tarski. E isso é evidenciado pelo próprio papel que cumprem as expressões indexicais nas línguas naturais, como já abordado nesta seção. É difícil, e talvez impossível, entrever um modo de especificar a função semântica que essas expressões exercem nas sentenças em que aparecem sem empregar noções do campo semântico ou pragmático do lado direito da equivalência. Como fornecer uma sentença-T para uma sentença simples com um demonstrativo, como ,aquele é atleta ${ }^{e e}$, sem especificar que essa setença é verdadeira somente quando o objeto demonstrado pelo falante que enuncia a sentença em um tempo t é atleta no tempo t? As noções linguísticas de falante, tempo e mesmo enunciado parecem não ser elimináveis na última etapa da prova, que é a sentenca-T. O significado de ,se não será esgotado somente pela estrutura de , , $\varsigma^{\text {ee }}$, mas com referência também a parâmetros contextuais, e estes constarão no lado direito da equivalência. E isso naturalmente produz a uma consequência esperada acerca da Convenção- $\mathrm{T}_{\mathrm{r}}$ : ao contrário da Convenção-T, ela "não está mais disponível como um teste formal" (idem), mas como critério empregado para a avaliação empírica de uma teoria de um fragmento de uma língua.

É fácil ver aqui que, sob essa abordagem, uma teoria que obedece à Convenção- $\mathrm{T}_{\mathrm{r}}$, ao

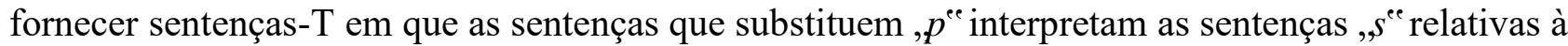
falante e tempo, implicará, por sua vez, a verdade de sentenças-M da forma ,s significa (expressa por $\mathrm{r}$ num tempo t) $p^{\text {ee }}$, ou seja, sentenças-M também parametrizadas. ${ }^{76}$

A respeito dessa relação entre uma sentença-T e uma sentença-M, Davidson comenta em "Semantics for Natural Languages":

Uma teoria da verdade implica, para cada sentença $s$, uma sentençada da forma,$s$ é

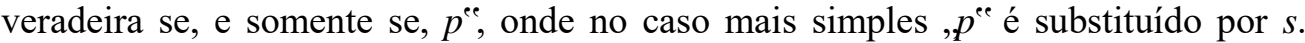
Uma vez que as palavras ,é verdadeira se, e somente se exão invariantes, podemos interpretá-las se nos agradar como significando ,significa que . Assim construída, uma amostra poderia ser lida "Socrates é sábio" significa que Socrates é sábio (Davidson 1990 [1970]: 60).

Ou seja, uma sentença-T que apresenta uma interpretação de uma sentença da linguagem objeto fornece o seu significado. No caso de uma linguagem insensivel ao contexto, o emprego de uma teoria da verdade que obedece à Convenção-T ilumina o significado porque fornece as condições de verdade de uma sentença usando uma sentença que a traduz. E no caso das línguas naturais, uma

\footnotetext{
${ }^{76}$ Lepore \& Ludwig $(2005$; 2007) especificam na própria estipulação da Convenção-T que uma teoria que obedece à ela acarretará sentenças-T às quais correspondem sentenças-M verdadeiras. Creio que isso seja um passo redundante, uma vez que sentenças-M serão implicadas por uma teoria que obedece à Convenção-T.
} 
teoria da verdadeira que respeita a Convenção- $\mathrm{T}_{\mathrm{r}}$ captura o significado porque exibe as condições de verdade de uma sentença interpretando-a relativa às situações de uso. Mas há uma observação logo nos dois parágrafos que se seguem imediatamente à passagem - e nos quais Davidson comenta o próprio fragmento citado - que chama a atenção para um elemento a mais que é fundamental em uma teoria semântica que toma a forma proposta. Continua Davidson:

Essa maneira de apresentar a relevância de uma teoria da verdade para questões do significado é iluminadora, mas devemos ter cuidado para não encorajar certos erros. Um erro é pensar que tudo o que podemos aprender de uma teoria da verdade sobre o significado de uma sentença particular está contido no bicondicional requerido pela Convenção-T. O que podemos apreender é apresentado antes na prova de tal bicondicional, pois a prova deve demonstrar, passo a passo, como o valor de verdade da sentença depende de uma estrutura recursivamente dada [...].

Ver a estrutura de uma sentença através dos olhos de uma teoria da verdade é vêla como construída por meio de mecanismos um número finito dos quais é suficiente para toda sentença; a estrutura da sentença, desse modo, determina a sua relação com outras sentenças. E de fato não há como fornecer as condições de verdade de todas as sentenças sem mostrar que algumas sentenças são consequências lógicas de outras (Davidson 1990 [1970]: 61).

Como o objetivo é de perseguir a estrutura composicional do significado das sentenças, uma teoria composicional da verdade deve permitir que olhemos para uma sentença-T tendo em perspectiva, por assim dizer, a trajetória composicional. É nos passos de derivação de uma sentença-T que se exibe a contribuição de cada expressão para as condições de verdade de todas as sentenças em que potencialmente a expressão pode ocorrer. É nos axiomas de satisfação para as expressões básicas que se modela a relação entre fragmentos da linguagem e objetos no mundo. E nesses axiomas apresenta-se no lado direito uma interpretação das expressões. Mediante esse processo, evidenciamse estruturalmente redes inferenciais entre sentenças. Isso porque a forma semântica de uma expressão capturada pelo axioma que nos dá as suas condições de satisfação permite que determinemos a contribuição semântica dessa expressão para as conexões inferenciais entre sentenças em muitas das quais a expressão aparece. Por exemplo, sabemos que a sentença „João pulou o muro rapidamente ${ }^{e c}$ implica que „João pulou o muroe ${ }^{e}$ Logo, uma teoria composicional da verdade deve exibir na prova da sentença-T de „João pulou ou muro rapidamente ${ }^{\text {ee }}$ arranjo estrutural que permite que inferir „João pulou o muro ${ }^{“ e}$. Se a construção de uma sentença-T para „João pulou o muro rapidamente ${ }^{e e}$ falha em exibir estruturalmente essa interdependência, então não obedecerá a Convenção-T e, logo, não poderemos dizer que ela nos fornece o significado da sentença. E como demonstraremos na seção sobre modificação adverbial, verbos de ação e relações causais, o papel estrutural de estabelecer redes inferenciais não será reduzido a expressões de uma língua natural que podemos interpretar como constantes lógicas, mas também a expressões que 
podem ser interpretadas como fornecendo quantificação implícita. Muitas sentenças apresentarão embora não empreguem nenhum termo descrito como uma constante lógica - uma forma semântica à luz da teoria da verdade na qual aparecem quantificações que garantem inferências lógicas entre sentenças.

A relativização do esquema-T e a Convenção- $\mathrm{T}_{\mathrm{r}}$ possibilitam que de fato se comece a visualizar seriamente como que uma teoria da verdade pode ter um papel central em uma semântica empírica. A introdução de variáveis que percorrem falantes e tempo para acomodar a relativização impõe que verdade seja caracterizada para uma sentença , se $^{\text {e }}$ com apelo a recursos que não estão em , $s^{\text {ee }}$, pois, como já dito, as variáveis para pessoa e tempo "devem aparecer no enunciado das condições de verdade" (Davidson 1990[1973]: 75). Uma teoria que gera sentenças-T na forma do esquema ,s é verdadeira em L expressa por $\mathrm{r}$ no tempo $\mathrm{t}$ se, e somente se, $p^{\text {ee }}$, “deve ser empírica em caráter e aberta a teste" (Davidson 1990[1973]: 73). O que significa que as sentenças-T de uma semântica empírica não podem ser verificadas unicamente pela sua estrutura, mas pela sua capacidade de iluminar condições de verdade de sentenças em uso. E é isso que garante que uma teoria da verdade como veículo de uma teoria do significado seja empírica. Como considera Davidson em "In Defense of Convention T" (1973) ${ }^{77}$, texto que já citamos algumas passagens neste parágrafo, "se tratarmos sentenças-T como verificáveis, então uma teoria da verdade mostra como podemos ir da verdade para algo como significado" (Davidson 1990[1973]: 74).

Há alguns pontos cruciais vagamente sugeridos acima que entendo essencial abordar aqui, para evitar falsas ideias e expectativas a respeito da relação entre teoria e evidência no projeto davidsoniano. Em uma teoria da verdade da forma contemplada por Davidson para uma língua natural intenta-se capturar estruturas das sentenças e não legislar sobre elas, no sentido de prescrevê-las. Uma descrição das estruturas das línguas naturais, uma vez que é aberta a testes, está “[...] sujeita a erro e condenada a ser até certo ponto incompleta e esquemática" (Davidson 1990[1970]: 59). Sob essa lente, a observação do caráter parcial da teoria, suscetível a revisões com base no comportamente das sentenças em uso de uma língua, não constitui um argumento contra a viabilidade do emprego de uma teoria formal para investigar as línguas naturais. O uso na teoria de noções semânticas tais como referência, satisfação, por um lado, e a análise das estruturas das sentenças em termos de nomes, quantificadores, predicados, conectivos, etc., por outro lado, são construções teóricas empregadas para predizer as condições de verdade das sentenças em uso. A teoria proposta é testada, então, pelo o que pode ser diretamente observável. E o que é aberto à

\footnotetext{
${ }^{77}$ Texto primeiramente lido em uma conferência intitulada Alternative Semantics, ocorrida na Temple University, em dezembro de 1970. Em 1973 o texto foi publicado no livro Truth, Syntax and Modality, editado pela Holland Publishing Company.
} 
observação, no caso das línguas naturais, é "o uso de sentenças no contexto" (Davidson 1990: 300). Por isso, uma teoria da verdade a serviço de uma teoria semântica é testada no nível das sentenças-T pelo o que é passível de observacão: o uso das sentenças por falantes em situações comunicativas. As sentenças-T em si não nos informam nada sobre os conceitos de satisfação e referência, ou sobre a estrutura de termos que não são sentenças. A postulação, no interior da teoria, de estruturas que compõem as sentenças e de conceitos semânticos tem a função de organizar, modelar os dados, de maneira a fornecer uma explicação do uso das sentenças. Em outros termos, o teste de uma teoria independe de intuições acerca do conceito semântico de satisfação que a teoria usa ou a sua classificação das categorias das expressões que não são sentenças. Uma vez que tais noções e categorias são "confrontadas diretamente com as evidências empíricas", seu valor empírico consiste na sua força explicativa e preditiva. Ou seja, tais construtos teóricos são avaliados pela adequação empírica das condições de verdade que fornecem, na estrutura das sentenças-T, para as sentenças de uma língua. Do que se segue que o teste da correção de uma classificação de uma expressão e da construção de uma cláusula de satisfação para ela, relacionando-a a objetos, dá-se na observação de como a descrição oferecida contribui para capturar as condições de verdade, relativas ao contexto, das sentenças. Em "Reality Without Reference" ${ }^{78}$, Davidson comenta sobre essa relação entre teoria e evidência:

\begin{abstract}
A teoria conterá, certamente, [...] um conceito como satisfação ou referência. Mas essas noções devem ser tratadas como construções teóricas cuja função é esgotada no estabelecimento das condições de verdade das sentenças. Do mesmo modo [...] para a forma lógica atribuída a sentenças, e todo o maquinário de termos, predicados, conectivos e quantificadores. Nada disso é aberto a confrontação direta com a evidência. Não faz sentido, nessa abordagem, queixar-se de que uma teoria oferece repetidas vezes as condições de verdade corretas, mas apresenta a forma lógica (ou estrutura profunda) incorreta. Devemos ter a mesma visão a respeito da referência. Uma teoria desse tipo não [...] explica referência, ao menos no seguinte sentido: ela não atribui conteúdo empírico diretamente a relações entre nomes ou predicados e objetos. Um conteúdo é fornecido indiretamenta a essas relações quando [um conteúdo é dado] às sentenças-T (Davidson 1990[1977]: 223).
\end{abstract}

A cláusula de satisfação, assim como a indicação de a qual categoria gramatical uma expressão pertence, estão sujeitas constantemente a revisões. Como exemplificamos com o caso do pronome demonstrativo „aquele ${ }^{e e}$ a revisão das condições de satisfação da expressão resultou diretamente da constatação de que descrições anteriores não davam conta de exibir as condições de verdade de algumas sentenças em que o demonstrativo aparece. Logo, a necessidade de modificação foi

\footnotetext{
${ }^{78} \mathrm{O}$ texto aparece pela primeira vez em um workshop sobre semântica e linguística na University of Estern Ontorio, Londres, em april de 1972. Com alterações importantes, ele foi publicado em 1977 na revista Dialectica, número 31, pp. 247-53.
} 
colocada pela observação de possíveis comportamentos de sentenças que a expressão compõe. É justamente a retalivização do esquema-T que abre a possibilidade de fornecer condições de verdade em conexão com os falantes de uma língua. O que se espera, com isso, é que o papel teórico de classificar as estruturas subsentenciais seja testado empiricamente. Sendo "sentenças o foco da interpretação empírica", os conceitos de referência e satisfação são circusncritos a sua função teórica no corpo de uma teoria que busca fornecer as condições de verdade das sentenças. Embora tais conceitos não sejam elimináveis teoricamente, Davidson não vê a necessidade de fornecer uma análise deles que seja independente da teoria. Isso porque, do ponto de vista do projeto, tais noções são empregadas na teoria tão somente como instrumentos que viabilizam um método de especificar composicionalmente os significados das sentenças, i.e., de exibí-las como resultando em parte "da sua estrutura e propriedades semânticas de suas partes" (Davidson 1990: 300). Além disso, uma vez que a axiomatização é testada pelas sentenças-T que gera, também as entidades que os axiomas de referência e satisfação relacionam com as expressões de uma língua povoam a ontologia da teoria se indispensáveis para a sua força explanatória.

A perspectiva que se ganha aqui, para concluir esta subseção, a respeito do projeto é que, dentro da teoria, as estruturas e objetos não observáveis postulados não precisam encontrar confirmação independente além da função que cumprem para caracterizar as condições de verdade das sentenças. E é no nível das sentenças, entidades observáveis e conectadas "com atividades e propósitos humanos" (Davidson 1990 [1977]: 222) que se testa a força preditiva do aparato formal empregado. A possibilidade de que essas estruturas postuladas sejam confrontadas com a evidência emerge da relativição do esquema-T às circunstâncias de uso das sentenças. Categorias gramaticais das palavras, noções semânticas e entidades necessarias para a construção de uma teoria formal da verdade são, no caso de uma teoria para as línguas naturais, sujeitas a revisões impostas pelo próprio caráter empírico que a teoria deve assumir. De maneira que o aspecto esquemático e sempre incompleto da teoria resulta da própria possibilidade de que ela seja empírica, aberta a testes. O que teremos são fragmentos da linguagem natural acomodados pela teoria, e novas evidências podem desafiar ou fortalecer o escopo de fenômenos linguísticos que a teoria consegue capturar. A relação entre teoria e evidência será, como em uma teoria com valor empírico, a de fornecer explicações capazes de descrever e prever determinados fenômenos. Por essa razão, é um equívoco esperar que uma teoria da verdade empregada em uma semântica para as línguas naturais deva realizar o mesmo grau de especificação formal da linguagem objeto que uma teoria para uma linguagem formalizada pode fornecer. Sentenças-T geradas composicionalmente serão confrontradas com as evidências referentes ao uso das sentenças de uma língua, e a subdeterminação das condições de verdade das sentenças demandará reajustes na própria caracterização das condições de satisfação previamente 
sugeridas para as expressões da linguagem. Fato esse que submete a teoria a constantes modificações e revisões. E é isso que se deve esperar, pois na verdade uma eventual rigidez e engessamento da teoria é que me parece uma evidência de que se estaria - ao invés de buscando explicar o comportamento das sentenças em uso - impondo estruturas exatas e não sujeitas a alterações.

\subsection{Quantificação em língua natural.}

Tarski nos mostrou como que a estrutura quantificacional presente no cálculo das classes, assim como na lógica de predicados, requer que abandonemos na construção de teorias da verdade para essas linguagens um método que fornece para as sentenças elementares uma lista de sentenças-T e que caracteriza recursivamente apenas os conectivos lógicos. A solução inaugural dos trabalhos de Tarski sobre a verdade consiste justamente no fato de que a introdução da relação de satisfação e a definição de verdade em termos daquele conceito permite que sejam elaboradas teorias nas quais os teoremas-T são gerados operando-se composicionalmente sobre a estrutura interna das sentenças de uma linguagem. Mediante cláusulas de satisfação, da forma ,, $(\forall f)(f \text { satisfaz ... } \leftrightarrow \text {... ... })^{\text {ee }}$, para as expressões predicativas e quantificadores de uma linguagem objeto, em que $f$ percorre sequências de objetos, pode-se especificar a contribuição dessas expressões subsentenciais que constituem as sentenças para as condições de verdade das sentenças nas quais aparecem. Esse mérito inovador de Tarski assume a forma de uma teoria recursiva da verdade que ilumina o papel das variáveis, predicados, conectivos e quantificadores para as condições de verdade das sentenças. Evidentemente que para Tarski chegar a esse resultado ele percorreu caminhos trilhados anteriormente. Frege já havia construído uma teoria da quantificação, sendo quem, pela primeira vez, possibilitou uma semântica que fosse além de um tratamento verofuncional das sentenças compostas. Contudo, somente a partir de Tarski pôde-se acomodar as expressões predicativas e os quantificadores em uma teoria formal da verdade para uma linguagem.

Em "True to The Facts" ${ }^{79}$ Davidson sintetiza de forma bastante esclarecedora como que a definição de verdade em termos da relação de satisfação soluciona o impasse colocado pela estrutura quantificacional para uma teoria da verdade:

O problema apresentado pela estrutura quantificacional para uma teoria recursiva da verdade é $[. .$.$] que embora sentenças de qualquer tamanho possam ser construídas a$ partir de um pequeno fornecimento de variáveis, conectivos, predicados e

\footnotetext{
${ }^{79}$ Artigo pela primeira vez apresentado em um simpósio sobre verdade, de 1969, promovido pela Eastern Division of the American Philosophical Association. No mesmo ano, ele foi publicado na revista Journal of Philosophy, 66, 748-64. É o terceiro texto de Inquiries into Truth and Interpretation.
} 
quantificadores, nenhuma parte das sentenças precisa ser por sua vez uma sentença; portanto, a verdade de uma sentença complexa não pode ser explicada em termos da verdade de suas partes.

Tarski nos ensinou a apreciar o problema e ele forneceu uma solução engenhosa. A solução depende, em primeiro lugar, de caracterizar uma relação chamada satisfação e então definir verdade por meio dela. As entidades que são satisfeitas são sentenças abertas e fechadas; os satisfadores (satisfiers) são funções que mapeiam as variáveis da linguagem objeto nas entidades que elas percorrem quase tudo, se a linguagem é o Inglês. Uma função satisfaz um predicado não estruturado $n$-ário com variáveis nos $n$ lugares se o predicado é verdadeiro das entidades (de forma ordenada) que a função assinala a essas variáveis. Então se,$x$

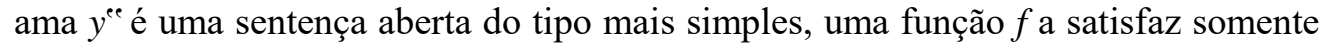
no caso em que a entidade que $f$ assinala a, $x^{\text {ec }}$ ama a entidade que $f$ assinala a, $y^{\text {ee }}$. A caracterização recursiva de satisfação deve percorrer, por sua vez, todo predicado primitivo. Ela lida com conectivos da maneira óbvia: assim, uma conjunção de duas sentenças $s$ e $t$ (abertas ou fechadas) é satisfeita por $f$ contanto que $f$ satisfaça $s$ e $f$ satisfaça $t$. A quantificação universal de um sentença aberta $s$ com respeito a uma variável $v$ é satisfeita por $f$ caso $f$, e toda outra função como $f$ exceto no que ela assinala a $v$, satisfaz $s$ (a sentença anterior funciona com ,existencial ${ }^{\text {ee }}$ substituindo „universale $\mathrm{e}$,ou algum ${ }^{\text {ee }}$ substituindo „e todo "). Se uma função particular satisfaz ou não uma sentença depende inteiramente de quais entidades ela assinala às variáveis livres da sentença. De maneira que se a sentença não tem variáveis livres - se ela é uma sentença fechada, ou genuína - então ela deve ser satisfeita por toda função ou nenhuma. E, como é claro nos detalhes da recursão, aquelas sentenças fechadas que são satisfeitas por todas as funções são verdadeiras; aquelas que nenhuma satisfaz são falsas (Davidson 1990[1969]: 48).

Ao definir verdade em termos de satisfação o que o método taskiano consegue é, via essa relação, acomodar em uma teoria as partes das sentenças às quais não se pode aplicar diretamente o predicado de verdade. Empregando o conceito de satisfação, que Davidson enxerga como "uma forma generalizada de referência (Davidson 1990: 296), na conformação de cláusulas ou axiomas das expressões que não são sentenças - o que possibilita relacionar partes de uma linguagem com os objetos sobre os quais a linguagem fala - a estratégia tarskiana codifica a estrutura quantificadorvariável . Por meio desse movimento, concebe-se, portanto, um modo indireto de aplicar o conceito de verdade ao cálculo de predicados. Mas como as conquistas desse método podem nos ajudar a construir teorias da verdade para as linguas naturais? Estudos em linguística sobre a interface sintaxe-semântica sugerem que podemos progredir significativamente no estudo das línguas naturais se tratarmos as estruturas internas das suas sentenças como codificando algo semelhante à forma quantificador-variável do cálculo de predicados. Fazendo uso na metalinguagem de uma notação da lógica de predicados podemos acomodar fragmentos das línguas naturais em que o comportamento semântico das sentenças indicam consistentemente padrões de quantificação, de maneira que podemos abstrair dessas sentenças expressões que operam basicamente como quantificadores. 
Todavia, não é preciso um exame muito detalhado para perceber que quantificação em língua natural é mais complexa do que na lógica de predicados. Há expressões que podem ser consideradas quantificadores, ou apresentarem em contextos específicos um comportamento de

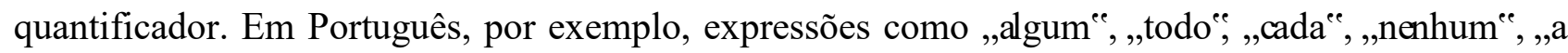
maioria de $e^{e e}$, ,todos ${ }^{e e}$, a minoria de $e^{e e},$, a totalidade de ${ }^{e e},$, um, ,o/a $a^{e e}$, etc. Além disso, quantificação em língua natural é, na maioria das vezes (talvez sempre) restrita, ou seja, a maioria dos quantificadores funciona como operando sobre conjuntos circunscritos de entidades. Casos como „todo menino", „,algum menino se houvesse uma variável encoberta, restrita ao conjunto dos meninos, presa pelo quantificador. Fatos como esses precisam ser acomodados numa teoria que emprega o método de Tarski para iluminar o papel das expressões ditas quantificacionais nas línguas naturais. Como mostraremos, adaptações nos axiomas de satisfações para os quantificadores restritos das línguas naturais possibilitam codificar a quantificação restrita em formas semânticas bastante precisas, de modo a acomodar fragmentos quantificados das linguas naturais em uma teoria da verdade à lá Tarski.

Mas antes de exibir axiomas para quantificadores restritos, retomemos como Tarski concebe satisfação para quantificações universal e existencial irrestritas. Adotarei daqui em diante, em consonância com Davidson, funções como satisfadores das expressões linguísticas. Recordem que para Tarski sequências de objetos aparecem como satisfazendo as expressões de uma linguagem. No seu método esse papel é mediado pela atribuição de índices numéricos às variáveis das expressões; as condições de satisfação são fornecidas correlacionando os objetos nas sequências às variáveis com índices. A opção de Davidson em usar funções como satisfadores é porque ela consiste numa estratégia mais direta de associar objetos às variáveis das expressões. Mas entendemos que ambas as alternativas, sequências ou funções, cumprem o mesmo papel, e a preferência por uma em detrimento da outra não altera a forma geral do método. $\mathrm{O}$ uso de funções apenas simplifica o procedimento.

Um quantificador pode ser concebido como um operador que, prefixado a uma expressão predicatica ,Fx ${ }^{e e}$, transforma-a em uma fórmula fechada. No caso de o quantificador ser universal, que aqui representamos com a notação $\forall$, a fórmula , $\forall \mathrm{x}$ : Fx ${ }^{\text {ee }}$ será verdadeira se, e somente se, os valores de x possuírem o predicado F. Já no caso de o quantificador ser existencial, representado aqui pela notação $\exists$, a fórmula,$\exists x$ : Fx $x^{e e}$ será verdadeira se, e somente se, ao menos um valor da varável x possuir F. Em uma teoria da verdade como a em questão, pode-se exibir o papel desses dois quantificadores mediante os seguintes axiomas de satisfação:

AX4. $(\forall f)(\forall \Phi)\left(f\right.$ satisfaz $\mathrm{QU}(\Phi, \mathrm{x}) \leftrightarrow \forall f^{\prime} \neq f$ no máximo no valor que atribui a $\mathrm{x}$ também 
satisfaz $\Phi)$.

AX5. $(\forall f)(\forall \Phi)\left(f\right.$ satisfaz $\mathrm{QE}(\Phi, \mathrm{x}) \leftrightarrow \exists f^{\prime} \neq f$ no máximo no valor que atribui a $\mathrm{x}$ também satisfaz $\Phi)$.

onde $f$ e $f^{\prime}$ são variáveis para as funções que satisfazem as expressões de uma linguagem, $\Phi$ representa uma expressão predicativa, QU e QE abreviam os quantificadores universal e existencial, respectivamente, e $\neq$ abrevia a expressão "que difere de". Tal forma de quantificação sobre funções que satisfazem expressões assinalando objetos às suas variáveis captura corretamente a quantificação sobre os objetos que as variáveis percorrem. De maneira que, via a aplicação da relação de satisfação para representar as quantificações universal e existencial, expõe-se, na forma de condições de satisfação, a contribuição dessas duas constantes lógicas na determinação das condições de verdade de sentenças quantificadas. Portanto, para uma fórmula do tipo „Qx: $\Phi x^{e e}$, em que ${ } Q^{\text {ee }}$ representa um dos dois quantificadores, consideram-se as funções $f$ ' que diferem de $f$ no máximo com respeito ao objeto assinalado à variável x presa pelo quantificador. Quando a quantificação é universal, toda função $f^{\text {ee } q u e ~ d i f e r e ~ d e ~} f$ no máximo no objeto que atribui à x deve satisfazer a expressão predicativa „, $\Phi^{\text {ee }}$, i.e., o objeto assinalado por $f^{\prime}$ deve também estar na extensão de,$\Phi^{\text {ee }}$. Quando a quantificação é existencial, basta uma $f^{\prime}$ que difere de $f$ no máximo no objeto que assinala à x satisfazer „Фx ${ }^{e e}$, i.e, retornar como valor de x um objeto que cai sob „, $\Phi^{e e}$.

Até agora tudo bem. Contudo, olhando para as línguas naturais, facilmente constata-se que a quantificação irrestrita representada em Ax4 e AX5, senão inexistente, é extremamente rara. Os quantificadores aparecem na grande maioria em estruturas sintáticas chamadas sintagmas nominais quantificados. Eles se concatenam a substantivos , como nas estruturas „,todo homem“e, ,algum gato ${ }^{\text {ee }}$, „muitos livros ${ }^{e e}$, etc. Por meio dessa forma de quantificação, em que ocorre uma restrição nominal, estamos interessando em dizer alguma coisa sobre um domínio restrito de objetos, e não sobre objetos em geral. Mesmo expressões como „todo mundo , ,,alguéme, não parecem ser empregadas para quantificar irrestritamente. $\mathrm{Na}$ maioria dos casos usamos essas expressões para quantificar sobre o domínio das pessoas.

Empregando aqui uma terminologia sintática, na sentença

\section{Todo filósofo escreve.}

o quantificador „todo“e se junta com a restrição nominal „filósofoee, para formar um sintagma quantificacional (em que o quantificador é o determinante) e, então, esse sintagma se liga ao 
sintagma verbal ,escreve ${ }^{\text {ee }}$ para formar um sintagma frasal, ou seja, uma sentença ${ }^{80}$. Neste caso, do ponto de vista semântico, o quantificador universal „todo ${ }^{\text {ee }}$ funciona como um operador que quantifica sobre o domínio dos filósofos e estabelece uma relação de implicação entre este domínio restrito e o domínio dos que escrevem: a sentença será verdadeira quando todas as entidades na

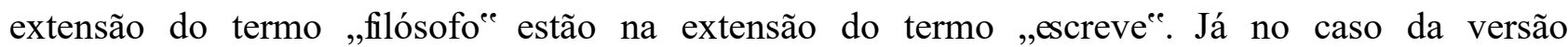
quantificada existencialmente da sentença,

\section{Algum filósofo escreve.}

o operador existencial ,algum ${ }^{\text {ee }}$ quantifica existencialmente sobre a conjunção dos dois domínios: a sentença será verdadeira quando houver ao menos uma entidade no domínio dos filósofos que também participa do domínio dos que escrevem.

A mensagem que se extrai do fato de que quantificação restrita é a forma dominante de quantificação em língua natural é que se queremos refletir nos axiomas de satisfação para os quantificadores das línguas naturais a semântica desses operadores temos de acomodar o seu comportamento. Uma estratégia correta a se adotar consiste em se apoiar na estrutura sintática mencionada acima, em que a quantificação restrita é vista como um sintagma quantificacional cujo determinante (,todoe, algum ${ }^{e e}$, „o/ae) se combina com um substantivo simples ou complexo (,mulhere, „mulher alta ${ }^{\text {ee }}$. O que precisamos, então, é fornecer uma cláusula de satisfação que exibe sob que condições funções satisfazem quantificações restritas. As sentenças „,todo filósofo escreve ${ }^{e e}$ e ,algum filósofo escreve ${ }^{e e}$, apresentam, de acordo com a sugestão sintática, a estrutura [s[snQx: $\left.\Phi]_{\mathrm{sv}} \Sigma\right]$. Interpretando, portanto, esta estrutura sintática, as revisões dos axiomas para os quantificadores universal e existencial são as seguintes:

AX6. $(\forall \mathrm{r})(\forall \mathrm{t})(\forall f)(\forall \Phi)(\forall \Sigma)(f$ satisfaz ,[todo x: $\Phi] \Sigma^{\text {ee }}$ expressa por $\mathrm{r}$ no tempo $\mathrm{t} \leftrightarrow \forall f^{\prime} \neq f$ no máximo no valor que atribui a $\mathrm{x}, f^{\prime}$ satisfaz $\Phi$ etambém satisfaz $\Sigma$ ).

AX7. $(\forall \mathrm{r})(\forall \mathrm{t})(\forall f)(\forall \Phi)(\forall \Sigma)(f$ satisfaz, ,[algum $\mathrm{x}: \Phi] \Sigma^{\mathrm{ee}}$ expressa por $\mathrm{r}$ no tempo $\mathrm{t} \leftrightarrow \exists f^{\prime} \neq f$ no máximo no valor que atribui a $\mathrm{x}$ e $f$ ' satisfaz $\Phi$ e também satisfaz $\Sigma$.). ${ }^{81}$

\footnotetext{
${ }^{80}$ Um sintagma é uma unidade sintática que pode ser formada por uma ou mais palavras. A definição do tipo de sintagma, se nominal, verbal, etc., dá-se de acordo com o seu núcleo. Se seu núcleo é um nome, o sintagma é nominal, se um verbo, o sintagma será verbal e se o se o núcleo é um quantificador o sintagma será quantificacional.

${ }^{81}$ Para um tratamento na mesma linha da quantificação restrita em língua natural ver Neale (1996; 2007) e Lepore \& Ludwig (2007).
} 
Notem que o que realizamos via os aximas AX6 e AX7 foi exibir nas suas condições de satisfação o comportamento dos quantificadores universal e existencial quando quantificam de forma restrita. Circunscrevemos as variáveis para as funções que satisfazem as expressões da linguagem objeto à expressão nominal que, junto com o quantificador, forma a estrutura de um sintagma quantificacional. Informados pelas teorias sintáticas e pelo comportamento semântico dos quantificadores em língua natural, ao representar os quantificadores restritos mediante a form geral „,[Qx: $\Phi(\mathrm{x})]^{\mathrm{ee}}$, conectamos estruturalmente o quantificador com a expressão predicativa que restringe o seu domínio de operação: o argumento do quantificador é uma expressão nominal cuja variável é presa pelo quantificador. E é essa estrutura complexa que se liga a outra expressão predicativa para formar uma sentença quantificada da forma, $[\mathrm{Qx}: \Phi(\mathrm{x})] \Sigma(\mathrm{x})^{e e}$. Representamos, portanto, nos axiomas acima essa operação que o quantificador estabelece entre duas expressões predicativas quando especificamos que toda função $f$ satisfaz uma sentença do tipo , $[\mathrm{Qx}: \Phi(\mathrm{x})] \Sigma(\mathrm{x})^{e e}$ quando toda função $f^{\prime}$ (no caso de quantificação universal), ou ao menos uma função $f^{\prime}$ (no caso de quantificação existencial), que difere de $f$ no máximo no valor que atribue à variável x, satisfaz tanto a expressão que ocupa o sintagma nominal quanto a expressão predicativa que aparece no sintagma verbal.

Mas a vantagem dessa estratégia não se restringe apenas ao fato de acomodar na teoria proposta a quantifição restrita. A sua generalidade permite que tratemos quantificadores em língua natural para os quais paráfrases em termos de quantificação sobre um condicional ou uma conjunção resultam em leituras equivacadas da semântica desses quantificadores. As sentenças „todo filósofo escreve ee $\mathrm{e}$,algum filósofo escreve ${ }^{e e}$ são adequadamente parafraseáveis na lógica de predicados e utilizando opeadores verofuncionais. A elas podem ser atribuídas as seguintes formas:

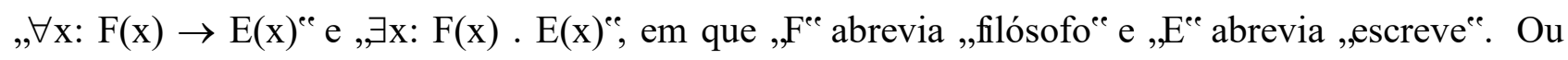
seja, paráfrases como „,todo x é tal que, se x é filósofo, então x escreve ${ }^{e e} \mathrm{e}$, ,existe ao menos um x tal que $x$ é filósofo e $x$ escreve ${ }^{e e}$. Todavia, se automaticamente realizarmos o mesmo procedimento com expressões quantificadoras como ,,a maioria $\mathrm{de}^{\mathrm{ee}}$, ,, $\mathrm{a}$ minoria $\mathrm{de}^{\mathrm{ee}}$, ,muitos ${ }^{\mathrm{ee}}$, etc, parece que não capturaremos as intuições dos falantes com respeito ao significado das sentenças em que essas expressões aparecem. Tomemos a sentença

\section{A maioria das atrizes é brasileira. ${ }^{82}$}

\footnotetext{
${ }^{82}$ Tomarei aqui „a maioria de cemo uma única palavra, embora essa expressão apresente uma estrutura interna formada por constituíntes que também são palavras. Mas vale apontar que em outras línguas esse quantificador pode ser expresso por uma única expressão, como no caso de ,moste, em Inglês, não apresentando problemas para tomá-lo como uma expressão básica. O propósito nesta subseção é tão somente de interpretar o significado dessa operação de quantificação na forma de um axioma de satisfação, partindo da evidência de que essa operação apareçe em diversas línguas na forma de um único vocábulo. Não está no escopo do que estamos tratando aqui uma análise morfossintática das expressões.
} 
Tal sentença só é verdadeira quando mais da metade das atrizes é brasileira. Por isso ela é falsa, já que o que ela diz não é o caso. Agora, atribuamos a seguinte paráfrase à (3): ,a maioria dos x é tal que, se x é atriz, então x é brasileira"e. O problema é que esta "paráfrase" não parece ser a maneira correta de regimentar (3): a paráfrase em termos de quantificação e uma estrutura condicional não seria equivalente à sentença em questão. O mesmo se dá se analisarmos (3) como ,a maioria dos x é tal que x é atriz e x é brasileirae ${ }^{e}$. O que essa interpretação diz é que a maioria das entidades é atriz e brasileira. Mas o significado de (3) é que a maioria das pessoas atrizes é brasileira. Portanto, tal alternativa também fracassa.

A lição, por isso, é que, embora (1) e (2) possam ser reescritas como quantificações tendo escopo sobre uma estrutura com conectivos verofuncionais articulando duas expressões predicativas, como comumente se mantém, o mesmo parece não ser extrapolável para (3). Operadores como ,a maioria de $\mathrm{de}^{\mathrm{ee}}$, , a minoria $\mathrm{de}^{\mathrm{ee}}$, ,,muitos ${ }^{\mathrm{ee}}$, seriam evidências convincentes de que há quantificações em língua natural que resistem a uma interpretação similar às paráfrases exibidas acima para ,todo ${ }^{e e}$ e, algum ${ }^{e e}$. E, por conseguinte, se queremos tratar de maneira a mais uniforme possível os quantificadores das linguas naturais, atribuir a todas as sentenças da forma „Q F são $G^{e e}$ estruturas equivalentes a „Qx: $\mathrm{F}(\mathrm{x}) \rightarrow \mathrm{G}(\mathrm{x})^{e e} \mathrm{e}$,QQx: $\mathrm{F}(\mathrm{x})$. G(x) é uma estratégia que fracassa. Mas os axiomas AX6 e AX7 já apontam para uma generalização mais promissora: tratar toda quantificação como circunscrita ao domínio das entidades na extensão da expressão nominal. Esse método trata a função semântica da expressão nominal ligada ao quantificador como sendo a de restringir o domínio da quantificação. Assim, o resultado é uma representação uniforme das sentenças quantificadas como ,,[Qx: $\Phi(\mathrm{x})] \Sigma(\mathrm{x})^{\text {ee }}$, onde a estrutura de um quantificador restrito é exibida, como já indicado acima, na forma ,,[Qx: $\Phi(\mathrm{x})]^{e e}$. O que se espera é que a expressão predicativa , $\Phi(\mathrm{x})^{e e}$ restrinja o domínio da quantificação, e que só então o quantificador também se aplique a,$\Sigma(\mathrm{x})^{e e}$. Para tanto, tem-se que restringir as funções avaliadas com relação à , $\Sigma(\mathrm{x})^{e e}$ somente às funções que satisfazem , $\Phi(\mathrm{x})^{\mathrm{ee}}$. E é isso que realizamos em Ax6 e Ax7, e que pode ser empregado também para a ,a maioria de ${ }^{e e}$, como abaixo:

AX8. $(\forall \mathrm{r})(\forall \mathrm{t})(\forall f)(\forall \Phi)(\forall \Sigma)(f$ satisfaz ,[a-maioria-dos $\mathrm{x}: \Phi] \Sigma^{\mathrm{ee}}$ expressa por $\mathrm{r}$ no tempo $\mathrm{t} \leftrightarrow$ a maioria $\operatorname{dos} f^{\prime} \neq f$ no máximo no valor que atribui a $\mathrm{x}$ satisfaz $\Phi$ e também satisfaz $\Sigma$ ).

A generalização para qualquer quantificação imediatamente sugere a si mesma: basta substituir

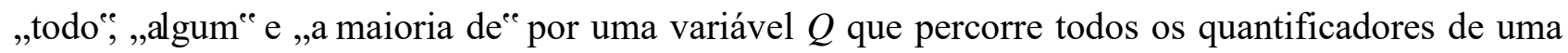
língua natural e que seja, por sua vez, quantificada universalmente: 
AX9. $(\forall \mathrm{r})(\forall \mathrm{t})(\forall f)(\forall Q)(\forall \Phi)(\forall \Sigma)\left(f\right.$ satisfaz , $[Q \mathrm{x}: \Phi] \Sigma^{e e}$ expressa por $\mathrm{r}$ no tempo $\mathrm{t} \leftrightarrow Q f^{\prime} \neq f$ no máximo no valor que atribui a x satisfaz $\Phi$ e também satisfaz $\Sigma$ ).

A título de ilustração da abrangência de AX9, olhemos para mais algumas estruturas quantificionais que, automaticamente, podem ser acomodadas por axiomas com a forma geral de AX9. Começemos com os artigos definidos, interpretados à lá Russell como introduzindo estrutras quantificacionais. Expressões como „o/a estudante ${ }^{\mathrm{ee}}$, representadas na forma „,[0/a x: $\left.\Phi\right] \Sigma^{\mathrm{ee}}$, recebem o seguinte axioma semântico:

AX10. $(\forall \mathrm{r})(\forall \mathrm{t})(\forall f)(\forall \Phi)(\forall \Sigma)(f$ satisfaz ,[o/a x: $\Phi] \Sigma^{\mathrm{ee}}$ expressa por r no tempo $\mathrm{t} \leftrightarrow \exists f^{\prime}(\forall g(g$ satisfaz $\Phi \leftrightarrow f^{\prime}=g$ ) e $f^{\prime} \neq f$ no máximo no valor que atribui a x e $f^{\prime}$ satisfaz $\Phi$ e também satisfaz $\Sigma$ ).

Mas presumivelmente AX10 pode ser simplificado, de maneira a não envolver explicitamente o uso da notação quantificacional empregada para descrever a unicidade veiculada pelo artigo definido:

AX10 $10 .(\forall \mathrm{r})(\forall \mathrm{t})(\forall f)(\forall \Phi)(\forall \Sigma)(f$ satisfaz ,[o/a x: $\Phi] \Sigma^{\mathrm{ee}}$ expressa por $\mathrm{r}$ no tempo $\mathrm{t} \leftrightarrow$ existe exatamente uma $f^{\prime} \neq f$ no máximo no valor que atribui a $x$ e $f^{\prime}$ satisfaz $\Phi$ e também satisfaz $\Sigma)$.

O quantificador „,nenhum “e também pode ser capturado com um axioma de satisfação. Basta negar no lado direiro da equivalência que exista uma função $f^{\prime}$ que satisfaça a expressão em questão:

AX11. $(\forall \mathrm{r})(\forall \mathrm{t})(\forall f)(\forall \Phi)(\forall \Sigma)(f$ satisfaz ,[nenhum $\mathrm{x}: \Phi] \Sigma^{\text {ee }}$ expressa por $\mathrm{r}$ no tempo $\mathrm{t} \leftrightarrow$ não existe uma $f^{\prime} \neq f$ no máximo no valor que atribui a x e $f^{\prime}$ satisfaz $\Phi$ e também satisfaz $\Sigma$ ).

O método pode imediatamente ser estendido para a quantifição numérica, como „três crianças ${ }^{\text {ee }}$, ,dez casas ${ }^{e e}$, etc. As condições de satisfação, por exemplo, para forma ,,[três x: $\left.\Phi\right] \Sigma^{\text {ee }}$, são:

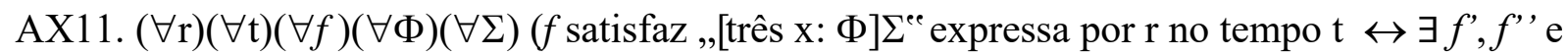

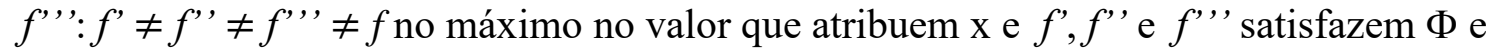
também satisfazem $\Sigma$ ).

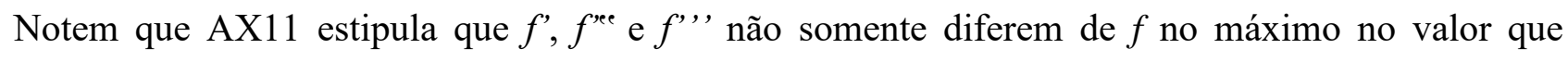
atribuem à variável x que ocorre em $\Phi$ e $\Sigma$, mas também entre si em relação ao valor que atribuem à x. E é isso que queríamos, pois sem essa condição não acomodaríamos a operação que „três ${ }^{\text {ee }}$ cumpre 
ao se ligar a uma expressão predicativa $\Phi$, que é justamente de selecionar três entidades distintas na extensão do predicado.

Para concluir esta subseção, quero chamar a atenção para a relação da proposta apresentada com outro método de tratamento dos quantificadores nas línguas naturais: a teoria dos quantificadores generalizados, desenvolvida por Barwise \& Cooper (1980) e bastante aceita na área. A viabilidade de se representar a quantificação restrita das sentenças quantificadas de uma língua natural em uma teoria que utiliza cláusulas de satisfação como as apresentadas acima mostra-se, quanto ao objetivo de uma semântica composicional, como uma alternativa a outras estratégias. Em especial à tese, bastante estabelecida em semântica formal, de que os sintagmas quantificacionais denotariam conjuntos de conjuntos de indivíduos. De acordo com esta perspectiva, as expressões „todo estudante estudantes $^{\text {ee }}$ denotariam os seguintes conjuntos:

$\alpha .[[\text { todo estudante }]]^{83}=\{\mathrm{X}:\{\mathrm{X}$ é estudante $\} \subseteq \mathrm{X}\}$

$\beta$. [[algum estudante $]]=\{\mathrm{X}:\{\mathrm{x}$ é estudante $\} \cap \mathrm{X} \neq \varnothing\}$

$\delta$. $[[$ nenhum estudante $]]=\{\mathrm{X}:\{\mathrm{x}$ é estudante $\} \cap \mathrm{X}=\varnothing\}$

$\phi .[[$ a maioria dos estudantes $]]=\left\{X: \mid\{\right.$ x é estudante $\left.\} \cap X \mid>\frac{\{\text { é estudante }\}}{2}\right\}$

$\gamma . \quad[[$ três estudante $]]=\{\mathrm{X}: \mid\{\mathrm{x}$ é estudante $\} \cap \mathrm{X} \mid=3\}$

Elucidemos em detalhe o que está em jogo nesta abordagem. Assume-se aqui que a denotação dos quantificadores é sempre uma relação entre conjuntos. A quantificação restrita $\alpha$ - resultante da composição do quantificador ,todo “eom a expressão predicativa ,estudante ${ }^{e e}$ denota o conjunto de todo conjunto $\mathrm{X}$ tal que o conjunto dos estudantes é um subconjunto de X. Logo, uma sentença como „todo estudante é inteligente ${ }^{e e}$ será verdadeira quando o conjunto dos estudantes for um subconjunto do conjunto das entidades inteligentes. ${ }^{84}$ Como pode ser notado, a distinção entre as expressões quantificacionais é representada por distintas operações estabelecidas entre os conjuntos e pela cardinalidade resultante dessas operações, como no caso de $\phi$ e $\gamma$. No caso $\phi$, a denotação de „a maioria dos estudantes ${ }^{e e}$ é o conjunto das intersecções do conjunto dos estudantes com X e que

\footnotetext{
${ }^{83}$ Os colchetes ,[[] ] ] colocados à esquerda e à direita das expressões linguísticas são notações padrões para representar a denotação das expressões.

${ }^{84}$ Para ficar mais claro, imaginem o seguinte cenário, em que $\mathrm{D}$ é o domínio de indivíduos: $\mathrm{D}=\{\mathrm{a}, \mathrm{b}, \mathrm{c}, \mathrm{d}, \mathrm{e}\}$; [[estudante] $]=\{\mathrm{a}, \mathrm{b}, \mathrm{c}\}$ e [[inteligente] $]=\{\mathrm{a}, \mathrm{b}, \mathrm{c}, \mathrm{d}\}$. Neste modelo,, todo estudante ${ }^{\text {ce }}$ denotará o seguinte conjunto de conjuntos: $\{\{\mathrm{a}, \mathrm{b}, \mathrm{c}\},\{\mathrm{a}, \mathrm{b}, \mathrm{c}, \mathrm{d}\},\{\mathrm{a}, \mathrm{b}, \mathrm{c}, \mathrm{e}\},\{\mathrm{a}, \mathrm{b}, \mathrm{c}, \mathrm{d}, \mathrm{e}\}\}$. Notem que o conjunto dos estudantes é um subconjunto de todos os conjuntos que pertencem ao conjunto denotado por ,todo estudante $e^{\text {ec }}$, inclusive o conjunto dos indivíduos inteligentes. De maneira que a sentença ,todo estudante é inteligente é é verdadeira - isto é, [[estudante] $] \subseteq[[$ inteligente $]]$ - se, e somente se, [[inteligente $]] \in[[$ todo aluno $]]$.
} 
possuem uma cardinalidade maior do que $\frac{\{\mathrm{x} \text { é estudante }\}}{2}$. Já „três estudantes ${ }^{\text {ee }}$ denotam o conjunto das interseções, de cardinalidade 3, do conjunto dos estudantes com X. Por fim, ,algum estudante denota o conjunto das inteseções não vazias do conjunto dos estudantes com $\mathrm{X}$, e „nenhum estudante ${ }^{e e}$, por seu turno, o conjunto das interseções vazias.

Tal maneira de tratar a quantificação implica evidentemente não apenas o uso de noções da teoria dos conjuntos em uma teoria semântica, mas a postura adicional de tomar conjuntos como denotações de certas expressões de uma linguagem objeto. Por outro lado, na nossa estratégia, conseguimos tratar a quantificação restrita sem apelar, na análise, a um maquinário que postula uma ontologia de conjuntos na extensão das expressões quantificacionais da linguagem sob investigação. Por meio do recurso de funções ou sequências de objetos, respeitamos o espírito das cláusulas de satisfação construídas por Tarski para os quantificadores irrestritos, e acomodamos a quantificação restrita sem analisar estruturas da forma , $[Q \mathrm{x}: \Phi(\mathrm{x})]^{\text {ee }}$ como conjuntos de conjuntos. ${ }^{85} \mathrm{O}$ propósito de uma teoria do significado como a sustentada aqui é, reiterando, de descrever o papel semântico das partes das sentenças na determinação das relações de implicação entre elas. Em especial no caso das constantes lógicas, que, pela sua própria semântica, operam fundamentalmente determinando redes inferenciais entre sentenças. Não está na barganha uma análise das expressões que intenta exibir mais estrutura do que é necessário para especificar a contribuição das palavras para as condições de verdade das sentenças. Entendo que não há nenhuma estrutura capturada pela tese ilustrada acima cuja ausência na estratégia que defendemos possa comprometer a descrição composicional do papel inferencial que as constantes lógicas acima cumprem nas línguas naturais. Espero ter mostrado, por essa razão, que para tratar a quantificação em língua natural no corpo de uma teoria composicional do significado não precisamos assumir entidades além das que são percorridas pelas variáveis das expressões predicativas. E, uma vez que se tem uma teoria que acomoda os mesmo dados com menos comprometimentos ontológicos, isso parace ser uma razão suficiente pela preferência por ela.

\subsection{Modificação adverbial e verbos de ação.}

\footnotetext{
${ }^{85} \mathrm{O}$ que não significa, evidentemente, que nenhuma categoria da teoria dos conjuntos é postulada. Observem que na metalinguagem empregamos funções ou sequências de objetos, que são conceitos da teoria dos conjuntos. Mas essas noções são parte dos conceitos e expressões da metalinguagem. Já a teoria dos quantificadores generalizados postula conjuntos como entidades na extensão das expressões da linguagem objeto.
} 
Em um conjunto de textos sobre ação, eventos e relações causais, mas especialmente nos artigos “The Logical Form of Action Sentences" (1967) ${ }^{86}$ " "The Method of Truth in Metaphysics" (1977) e “Adverbs of Action" (1985) ${ }^{87}$, Davidson fornece uma explicação geral de como tratar sentenças que contêm verbos de ação e advérbios. Nesta estratégia é defendida a tese de que as estruturas semânticas dessas sentenças podem ser exibidas tratando-as "como possuindo uma estrutura quantificacional não aparente na superfície” (1990 [1967]: 210-11). Nela, eventos como entidades entram em cena, e as sentenças de ação envolverão quantificação sobre variáveis que percorrem eventos. Como resultado, além de objetos, eventos são incluidos na ontologia das línguas naturais e acomodados em uma teoria da verdade como valores de variáveis nos axiomas de satisfação para uma classe importante de verbos. Há dois pontos salientes, que se complementam, e que alicerçam a defesa de Davidson de uma semântica de eventos. São eles: (i) o reconhecimento do nosso comprometimento ontológico com eventos ao usarmos a linguagem e uma inclusão adequada dessa categoria em uma teoria semântica dariam conta de capturar uma série de fenômenos linguísticos até então não satisfatoriamente explicados; e (ii) o método contribui para lançar luz sobre a relação entre uma teoria da verdade, forma lógica e ontologia da linguagem objeto. Nesta subseção, examinarei esses dois pontos e, no percurso, abordarei o debate entre Davidson e Quine acerca da existência de um critério formal que garanta a individuação de eventos como entidades particulares. Com isso, intento mostrar que o fato de o reconhecimento de Davidson quanto ao seu fracasso em fornecer um critério de admissibilidade ontológica para eventos não ter sido suficiente para que ele abandone uma ontologia de eventos, resulta fundamentalmente de duas razões que na filosofia de Davidson se conectam. Uma primeira, é que não parece haver uma alternativa sem a reificação de eventos que consiga fornecer um tratamento composicional das sentenças de ação com advérbios que elucide intuições triviais que qualquer falante de uma língua percebe acerca das redes inferencias que tais sentenças induzem. Ou seja, postular evento é útil, independentemente de se as condições de individuação dessa entidade sejam obscuras, porque assegura que um fragmento significativo das línguas naturais seja analisado no corpo de uma teoria sistemática. A segunda razão, que justifica, por assim dizer, uma posição metafísica de Davidson, consiste na visão de que negar a existência de eventos como entidades particulares nos comprometeria com uma ideia difícil de sustentar: que todas as sentenças que descrevem alguma forma de ação seriam falsas. Logo, qualquer metafísico que aceita que há sentenças sobre mudança que são verdadeiras, se as formas

\footnotetext{
${ }^{86}$ Texto primeiramente apresentado em uma conferência intitulada The Logic od Decision and Action, na Universidade de Pittsburg, em março de 1966. O artigo foi publicado no ano seguinte, no livro Logic of Decision and Action, University of Pittsburg Press, 1967.

${ }^{87}$ Artigo publicado pela primeira vez em Essays on Davidson: Actions and Events, editado por Bruce Vermazen e Merrill Hintikka, Oxford University Press, 1985.
} 
lógicas propostas por Davidson para essas sentenças estiverem corretas, terá de incluir eventos na sua ontologia. Vejamos de perto, então, a conformação da semântica de eventos proposta por Davidson.

\subsubsection{Forma lógica das sentenças de ação e modificadores adverbiais como predicados.}

Consideremos o conjunto de sentenças abaixo:

1. Pedro beijou Maria no parque pela manhã às $9 \mathrm{~h}$.

2. Pedro beijou Maria no parque pela manhã.

3. Pedro beijou Maria no parque.

4. Pedro beijou Maria.

Qualquer um que compreende os significados das sentenças acima aceita naturalmente que há entre elas fortes relações de inferência. A verdade da sentença (1) acarreta logicamente as sentenças (2) (3) e (4); da sentença (2) infiro as sentença (3), e desta deduzo (4). Um aspecto bastante evidente dessa rede inferencial consiste no fato de que as quatro sentenças parecem possui um mesmo verbo, „,beijaree, que indica movimento, mudança. Essa primeira evidência imediatamente indica que a direção mais acertada para se iniciar uma hipótese acerca das estruturas que conectam essas sentenças seja já de início assumir como relativamente claro que o verbo „beijare cumpre um papel determinante para as inferências intuídas. Tal constatação, aparentemente trivial, sugere que as expressões adverbiais ,no parque ${ }^{e e}$, ,pela manhãee e ,às $9 \mathrm{~h}^{\text {ee }}$ parecem modificar a ação indicada pelo verbo. Contudo, a estratégia mais comum para representar as quatro sentenças acima, empregando a simbolização padrão para exibir a adicidade dos verbos, negligencia de antemão o caminho que o próprio comportamento das sentenças indica. E essa postura é bastante recorrente em muitos livros introdutórios de lógica. Tomemos a sentença (1). Numa análise convencional, é comum simbolizar (1) como uma sentença com um verbo que pede cinco $\operatorname{argumentos,~i.e.,~,Beijar~}(x, y, u, v, z)^{\text {ee }}$, em que $x$ e $y$ são substituídas pelos termos singulares „Pedro ${ }^{c e} \mathrm{e}$, ,Maria ${ }^{c e}, \mathrm{e} u, v, z$ pelas expressões adverbiais „,pela manhãe ${ }^{e e}$, ,no parque ${ }^{e e}$, ,pela manhã ${ }^{\text {ee }} \mathrm{e}$, ,às $9 \mathrm{~h}^{\text {ee }}$, respectivamente. Agora, como então simbolizar a sentença (2)? Bem, o método sugere-se a si mesmo: tratar „beijar"e como um verbo de 4-lugares, que estabelece uma relação entre os referentes de „Pedroe, „Maria ${ }^{e e}$, „no parque ${ }^{e e}$, e ,pela manhã ${ }^{e e}$. Isso posto, é evidente a receita a seguir para as sentenças subsequentes. (3) resulta numa sentença com um verbo que pede três argumentos e que estabelece uma relação entre „Pedro , „Maria e „, no parque $^{e e}$ na ordem indicada pela própria sentença. Por fim, a sentença (4) apresenta um verbo de dois lugares, sendo os dois argumentos ocupados pelos referentes de „Pedro“e „Maria ${ }^{c e}$, 
respectivamente. Mas notem que essa proposta é uma falsa solução, pois, com respeito a iluminar a dependência semântica entre as sentenças, nos deixa no mesmo lugar de antes. O custo de analisar as quantro sentenças como contendo distintos verbos é que essa estratégia não explica as relações de inferência entre (1-4). Um aspecto importante de se aprender o significado de um verbo é saber quantos argumentos ele pede, pois a sua adicidade é parte integrante do seu significado. Logo, uma vez que tal análise assume cada uma das sentenças como possuindo um verbo distinto, com um significado distinto, ela não ilumina o que é essencial na intuição dos falantes sobre (1-4) e que, em parte, assegura o acarretamento entre as sentenças: que elas todas descrevem uma mesma ação e que partilham um mesmo verbo. Como resultado, essa abordagem, contra o entendimento dos falantes, descreve as quatro sentenças como tendo significados distintos e independentes. O que implica que, sempre que adicionarmos uma nova expressão adverbial a uma sentença com um verbo de ação, estaremos diante de um novo verbo.

Dessa posição emergem consequências, do ponto de vista do projeto davidsoniano, comprometedoras para uma teoria semântica das línguas naturais. Dado que a nossa capacidade linguística de introdução de novas expressões adverbiais parece consistir num mecanismo de iteração, somos forçados, sob essa descrição, a concluir que todo termo verbal que denota ação é, em potência, infinitamente polissêmico. É facil de ver aqui que isso quer dizer que tal análise exibe uma língua natural com um vocabuário básico infinito de verbos, violando, assim, o critério de aprendizagem, pois a apresenta como impossível de ser adquirida por um ser finito e com capacidades finitas. O método de conceber um novo verbo a cada nova expressão adverbial introduzida, fracassa, portanto, em duas frentes substanciais: não respeita o critério de aprendizagem e não exibe como que as estruturas das sentenças com verbos de ação e expressões adverbiais operam na determinação das redes de inferência entre as sentenças.

Mas há uma proposta alternativa que tenta superar em especial o fato de a estratégia anterior não permitir que da verdade de (1) possamos inferir a verdade das outras três sentenças. A tese é de que sentenças de ação sem expressões adverbiais são elipses de sentenças com quantificação. (4e) seria uma elipse de de (4):

\section{Pedro beijou Maria em algum lugar.}

A vantagem imediata dessa solução sobre a anterior é que ela permite que (3) formalmente implique (4) e (4`), pois se ,Pedro beijou Maria no parque ${ }^{e e}$, então „Pedro Beijou Maria ${ }^{e e}$, que não é senão a forma elíptica de $\left(4^{e `}\right)$. Consequentemente, posso explicar as relações entre as quatro sentenças em questão. Isso porque Pedro ter beijado Maria no parque pela manhã às $9 \mathrm{~h}$ acarreta que Pedro beijou 
Maria em algum lugar, em algum período e em algum instante. A consequência é que (4) terá, na verdade, uma elípse para cada uma das expressões adverbiais que aparecem em (1). Algo como

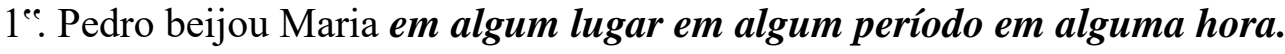

Contudo, essa estratégia também apresenta algumas dificuldades. Ela não pode especificar de antemão o número de expressões predicativas que podem operar como argumentos de um verbo de ação; pois não é necessário ter um limite para a introdução de novas expressões adverbiais. Qualquer sugestão de restrição soa claramente ad hoc. Como resultado, uma vez que sempre podemos adicionar mais um modificador adverbial a uma sentença de ação que já contenha um conjunto de modificadores, para acomodar a dependência estrutural entre (4) e

5. Pedro beijou Maria no parque pela manhã às 9h no dia 21 de março de 2002.

temos de assumir que (4) seja elipse de

\section{$5^{\mathrm{e}}$. Alguém beijou alguém em algum lugar em alguma hora em algum dia de algum ano.}

O que sugere uma simbolização como

$$
5^{\text {eee }} . \exists x_{1} \exists x_{2} \exists x_{3} \exists x_{4} \exists x_{5} \exists x_{6} \exists x_{7} \operatorname{Beijar}\left(x_{1}, x_{2}, x_{3}, x_{4}, x_{5}, x_{6}, x_{7}\right) \text {. }
$$

em que o verbo „,beijar ${ }^{\text {ee }}$ passa a pedir 7-lugares e quantifica-se existencialmente sobre cada uma das variáveis que ocupam as posições de argumento. Mas por que sete e não oito, ou trinta argumentos? Parece ser, em princípio, infinito o número de expressões adverbiais que podemos adicionar à simbolização ( $5^{\text {eee }}$ ) sem sacrificar a gramaticalidade das sentenças. Logo, impossibilitados de decidir sobre a adicidade do verbo „beijare, seria mais apropriado representá-lo como

$$
5^{\text {eceee }} \exists x_{1} \exists x_{2} \exists x_{3}, \ldots, \exists x_{n} \operatorname{Beijar}\left(x_{1}, x_{2} x_{3}, \ldots, x_{n}\right) \text {. }
$$

Com isso, indicamos a possível infinitude da sua adicidade. A generalização que resulta desta proposta é imediata: todos os verbos de ação passam a ser concebidos como tendo uma adicidade que não pode ser especificada. Tal problema Anthony Kenny cunhou de o impasse da 
"poliadicidade das variáveis" dos verbos de ação ${ }^{88}$. Mas uma análise que induz essa conclusão tem implicações desastrosas para uma teoria do significado. Uma vez que o número de modificadores potenciais que um verbo pode tomar parece não ter um limite especificado, e tendo em mente que parte da habilidade de compreender um verbo consiste em reconher sua adicidade, em princípio parece que nosso conhecimento de um verbo seria no mínimo parcial. Pois, como resultado desta perspectiva, uma condição necessária para o conhecimento completo de um verbo de mudança/ação seria que, ao aprendermos um verbo, aprendemos sua adicidade indeterminada. Mas isso parece impossível para um ser finito. Consequentemente, nossa mortalidade evitaria que compreendêssemos qualquer verbo de mudança. Essa segunda proposta, portanto, ainda que tenha a vantagem sobre a primeira no sentido de fornecer uma explicação para as inferencias entre as quatro sentenças, ainda é deficitária, pois sacrificaria o princípio de aprendizagem.

Desse modo, não podemos nem tratar (1-4) como contendo distintos verbos, tampouco que verbos de mudança possuem, a princípio, uma adicidade indeterminada. Precisamos de uma solução semântica que explicite a nossa intuição, como falantes, de que há inferencias válidas entre as quatro sentenças como resultante de uma estrutura composicional comum a elas.

A proposta de Davidson é concebida como uma resposta aos problemas acima, i.e., como uma alternativa que supera as dificuldades das estratégias anteriores. Em "The Logical Form of Action Sentences", Davidson introduz a essência da sua análise na seguinte passagem:

A ideia básica é que verbos de ação - verbos que dizem „o que alguém fez ${ }^{\text {e }}$ - deveriam ser construídos como contendo um lugar para termos singulares ou variáveis, que eles não parecem conter. Por exemplo, normalmente supomos que ,Shem kicked Shaun ${ }^{\text {ee } 89}$ contenha dois nomes e um predicado de dois lugares. Sugiro que, contudo, pensemos ,chutou ${ }^{\text {ec }}$ como um predicado de três lugares, e que a sentença tenha a seguinte forma:

$(\exists x)($ Kicked(Shem, Shaun, $x))$.

Se tentarmos uma sentença em Inglês que diretamente reflete essa forma, encontraremos dificuldades. „There is an event $\mathrm{x}$ such that $\mathrm{x}$ is a kicking of Shaun by Shem ${ }^{e 90}$ é o melhor que posso fazer, mas devemos lembrar que „a kicking ${ }^{\bullet e}$ não é um termo singular (Davidson 2011[1967]: 118-19).

Olhemos de perto (1-4) sob a lente fornecida neste fragmento. Em primeiro lugar, de imediato percebe-se que uma simbolização do verbo „beijarec como um predicado de três lugares, em que um dos argumentos consiste em uma variável quantificada existencialmente e cujo valor é um evento, permite que representemos as quatro sentenças como descrevendo um mesmo evento de Pedro

\footnotetext{
${ }^{88}$ Ver Kenny, A.J.P., Action, Emotion and Will. Routledge and Kegan Paul, London, 1963.

89 ,Shem chutou Shaun ${ }^{\text {ee }}$.

90 ,Existe um evento x tal que x é um chutar de Shaun por Shem ${ }^{e e}$.
} 
beijar Maria. Sentenças de ação são interpretadas como introduzindo uma quantificação existencial encoberta que prende uma variável que percorre eventos. Sob essa descrição, o verbo „beijar contribuiria com a seguinte estrutura semântica nas sentenças (1-4):

6. (ᄏe) (Beijar(e, pedro, maria)).

$\mathrm{Na}$ forma (6) ,beijar ${ }^{\text {ee }}$ descreve um evento em que um indivíduo (pedro) beija outro (maria). Notem que essa forma não é senão uma simbolização da sentença (4). Essa constatação já dá uma indicação de que estamos no caminho certo, pois é fácil de ver que a estrutura representada em (6) está presente nas sentenças (1-4). Também é de fácil percepção que (1-3) possuem mais estruturas do que (4), uma vez que nelas aparecem expressões adverbiais. O que coloca a questão: que papel estrutural cumprem ,no parque ${ }^{e e}$, ,pela manhãee e, às $9 h^{\text {ee }}$ no percurso de inferências que queremos descrever? Sem uma caracterização correta da modificação adverbal a análise resulta parcial, e ficamos, por assim dizer, a meio caminho de atribuir uma base semântica para as inferências que identificamos. Aqui é um caso em que a gramática tradicional nos dá uma pista. A função dos modificadores adverbias é modificar o verbo. Embora essa descrição não revele muita coisa, ela aponta na direção correta e indica onde olhar. Mas a análise da estrutura semântica interna do verbo „,beijar ${ }^{\text {ee }}$ sugere o tipo de modificação que „no parque ${ }^{e e}$, ,pela manhãe e ,às $9 \mathrm{hs}^{\text {ee }}$ cumprem. Essas expressões modificam o evento de Pedro beijar Maria: tal evento ocorreu no parque, pela manhã e às 9hs. Modificadores adverbiais passam a ser encarados como predicados de eventos, caracterizando-os e contribuindo para a sua identificação. Desse modo, as inferências em (1-4) são iluminadas por uma forma lógica que (i) apresenta um operador existencial que quantifica sobre um evento, (ii) um predicado verbal de três lugares - ,beijar(e, pedro, maria') - e (iii) modificadores adverbiais como predicados de eventos ligados por conjunção ao verbo. De maneira informal, mediante tal tratamento especificamos as condições de verdade de (1). Esta é verdadeira se, e somente se, existe um evento de Paulo beijar Maria, tal evento ocorreu no parque, tal evento foi pela manhã e tal evento aconteceu às $9 \mathrm{~h}$. Do que infiro que existe um evento de Paulo beijar Maria e tal evento ocorreu no parque e tal evento foi pela manhã, que, por sua vez, acarreta que existe um evento de Paulo beijar Maria e tal evento aconteceu às $9 \mathrm{~h}$; do qual concluo que existe um evento de paulo beijar maria. As representações em forma lógica, propostas por Davidson, para (1-4), são as seguintes:

7. ヨe: (beijar(e, pedro, maria) \& no parque $(e) \&$ pela manhã $(e) \&$ às $9 \mathrm{~h}(\mathrm{e})$

8. $\exists$ e: beijar(e, pedro, maria) \& no parque(e) \& pela manhã(e) 
9. ヨe: beijar(e, pedro, maria) \& no parque(e)

10. $\exists$ e: beijar(e, pedro, maria)

As formas lógicas acima têm a vantagem de revelarem as conexões intuitivas de significado que um falante percebe entre as quatro sentenças. Um mérito importante de tratar os verbos de ação como contendo um argumento para evento e de descrever os modificadores adverbiais como predicados ligados por conjunção ao verbo, e não como parte integrante do mesmo, é que as inferências válidas em (1-4) são explicadas mediante a regra simples de que predicados ligados por conjunção podem ser subtraídos e a verdade continua sendo preservada. Se um predicado complexo „F(x) \& G(x) é verdadeiro do mesmo objeto, então ambos os predicados simples também o são. Mediante a regra da conjunção verofuncional - isto é, a regra que diz que uma conjunção é verdadeira somente no caso em que seus conjuntos são verdadeiros - mais o tratamento dos modificadores como predicados de um mesmo evento, conseguimos exibir composicionalmente as relações inferenciais. E aqui o paralelo com o comportamento dos adjetivos não é mera coincidência. Da mesma maneira que a verdade de uma sentença como „Maria é bonita e alta"e, em função da regra da conjunção, acarreta que „Maria é bonita ${ }^{e e}$, „Pedro beijou Maria no parque pela manhãee, pela mesma regra da conjunção, acarreta que „Pedro beijou Maria no parque ${ }^{e e}$, que, por seu turno, acarreta que „Pedro beijou Maria ${ }^{e e}$. Nesse tratamento, ,no parque ${ }^{e e}$, pela manhãe e ,às $9 h^{\text {ee }}$ são atributos de um mesmo evento trasnversal às quatro sentenças. Além do mais, a remoção de um modificador adverbial via aplicação da regra de eliminação da conjunção respeita um aspecto distintivo do comportamento sentencial dessas expressões: todos os modificadores adverbiais que aparecem em uma sentença podem ser removidos e ainda e tem-se como resultado uma sentença. E é exatamente isso que ocorre com (4). Portanto, podemos tratar assim a regra de eliminação aplicada a modificadores adverbiais lidos como predicados de eventos:

i. $\exists$ e: Pe \& Qe

$\therefore \exists \mathrm{e}: \mathrm{Pe} \quad$ (i, eliminação de \&)

A tese de que em nossa fala sobre ação pressupomos a existência de eventos, de que a forma lógica das sentenças de ação exibe uma quantificação existencial sobre eventos, sendo os modificadores adverbiais predicados dessas entidades quantificadas, aponta para a solução de um conjunto relevante de problemas semânticos. Vejamos em detalhe alguns deles.

Tal estratégia facilmente explica a relação entre sentenças de ação e sua transformação em descrições definidas. Posso descrever (3) como 
11. O beijo de Pedro em Maria foi no parque.

Na análise de Davidson sentenças como „Pedro beijou Maria “e não descrevem, tampouco se referem, a qualquer evento em particular. Elas possuem um quantificador existencial ligando uma varável para evento. Em função do seu significado somente não há nada na forma lógica de sentenças simples de ação que decreva um único evento. E essa generalidade está bastante em conformidade com nosso uso dessas sentenças. „Pedro beijou Maria ${ }^{e e}$ pode claramente descrever mais de um evento de beijar. Ao enunciar essa sentença não me comprometo com qualquer ideia de unicidade, apenas indico que houve ao menos um evento de beijar. Mas tenho à disposição o mecanismo gramatical de nominalização dos verbos de ação antecedido por um artigo definido quando intento transmitir não apenas a ideia de existência, mas também de unicidade de um evento. (11) descreve um único evento de beijar. Da mesma maneira que empregamos descrições definidas para falar de pessoas e objetos, também o fazemos no caso de eventos. Parafraseando as descrições definidas de eventos também como estruturas quantificacionais, consegue-se incorporar esses casos a paráfrases russellianas. Com isso, elucidamos as diferenças de significado entre (3) e (11), e como de (11) posso inferir (3). Assim como a verdade da descrição definida „O irmão da Maria viajou acarreta que „Algum irmão da Maria viajoue, mas a verdade da última não acarreta a da primeira, de „o beijo de João em Maria foi pela manhãe, conclui-se que „João beijou Maria pela manhã ${ }^{e c}$. A forma lógica de (11) acarreta a forma lógica de (3):

12. $\exists$ e: $\forall \mathrm{e}^{e e}\left(\right.$ beijar( $\left(\mathrm{e}^{e e}\right.$, pedro, maria) \& pela-manhã $\left.\left(\mathrm{e}^{e \mathrm{e}}\right) \leftrightarrow \mathrm{e}^{\mathrm{ee}}=\mathrm{e}\right) \&$ foi-pela-manhã $\left.(\mathrm{e})\right)$. $\therefore \exists$ e: beijar(e, pedro, maria) \& pela-manhã(e).

Uma consequência positiva essencial desta proposta de Davidson diz repeito à individuação de um mesmo evento por meio da aplicação de predicados complexos que contenham distintas descrições de um indivíduo. Se Maria casou com o seu ex-vizinho, e seu ex-vizinho é o dono da mercearia do bairro, então a codenotação de „o seu ex-vizinho ${ }^{\text {ee }}$, „o dono da mercearia do bairro ${ }^{\text {ee }}$ assegura que os predicados,$x$ é um casamento de Maria com seu ex-vizinho ${ }^{c e} \mathrm{e}, x$ é um casamento de Maria com o dono da mercearia do bairro ${ }^{\text {ce }}$ sejam coextensivos. Logo, „o casamento de Maria com o seu ex-

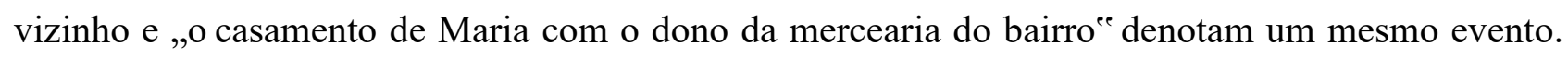
Assim, o princípio de substitutividade é garantido.

Descritas como frases existenciais, Davidson, portanto, incorpora as sentenças de ação à teoria russelliana das descrições definidas e indefinidas. Estratégia que se apresenta como solução 
unificadora e empiricamente sustentada, pois dá conta de abarcar um conjunto maior de fenômenos linguísticos via uma única teoria.

A quantificação sobre eventos também ilumina o uso anafórico de pronomes que retomam expressões previamente mencionadas que não descrevem indivíduos, mas ações. Os pronomes como „ele ${ }^{e e}$, „ela (retomam) a termos anteriormente usados. Em uma interpretação de „Pedro acha que ele ganhará a corrida $^{\text {ee }}$, por exemplo, „ele correfere com „Pedro“. Em termos mais técnicos, dizemos que pronomes anafóricos precisam de um outro sintagma nominal (sua anáfora) para determinar a sua referência. Mas pronomes anafóricos parecem não somente correferir com expressões que denotam

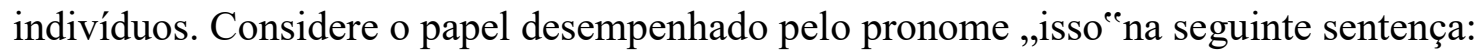

13. Pedro pintou o quarto e fez isso sem a ajuda de Paulo.

Qual é a anáfora de „isso ${ }^{\text {ee }}$ „Pedro“e, tampouco „o quarto outro sintagma nominal. Então o que mais pode ser a anáfora de „isso assume eventos como argumentos dos verbos de movimento dá uma resposta simples: „isso “e se

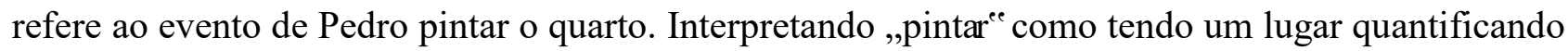
existencialmente sobre eventos, (13) pode ser reescrito da seguinte forma:

14. $\exists \boldsymbol{e}$, tal que $\underline{\boldsymbol{e}}$ é um evento de Pedro pintar o quarto, e $\underline{\boldsymbol{e}}$ ocorreu sem a ajuda de Paulo.

A solução para a quantificação universal explícita em sentenças como „Todo jogo de futebol atrai platéia emerge naturalmente. Esta sentença pode ser parafraseada como

15. $\forall$ e: jogo-de-futebol(e) $\rightarrow$ atrai-platéia(e).

Sentenças que indicam relações causais são incorporadas também a uma semântica de eventos. Este esquema explicativo fornece um tratamento do verbo ,causar ${ }^{\text {ee }}$ como um predicado relacional que toma dois eventos como argumentos. A sentença „A explosão causou a queda da ponte ${ }^{e e}$ é, então, interpretada como estabelendo uma relação entre dois eventos particulares denotados por descrições definidas. E isso é evidenciado na paráfrase

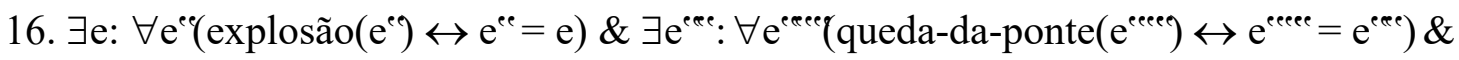
e causou $\mathrm{e}^{\text {ecee }}$ 
Em (16) o verbo „causar ${ }^{\text {ee }}$ funciona como um predicado de dois lugares que estabelece uma relação de causalidade entre eventos. Esta abordagem original pode ser estendida para outros verbos que expressam noções de causalidade, como „provocare, „ocasionar ${ }^{\text {ee }}$, „derrubar"e, etc. Sentenças que indicam relações temporais via o emprego de advérbios de tempo como „antes exibem estruturas semelhantes à (16). „O casamento de Maria foi depois do casamento de Joana Neste caso, „depois ${ }^{\text {ee }}$ estalece uma relação de precedência de um evento particular com respeito a outro evento particular.

A estrutura partilhada que garante referências entre sentenças com quantificação explícita e implícita sobre eventos pode ser também explicitada agora. Por exemplo, a estrutura do silogismo abaixo

\section{Todo correr queima caloria}

João correu

Logo, caloria foi queimada ${ }^{91}$.

pode ser capturada na paráfrase

18. $\forall \mathrm{e}: \operatorname{correr}(\mathrm{e}) \rightarrow \exists \mathrm{e}^{\mathrm{ee}}:$ queima-de-caloria( $\left.\mathrm{e}^{\mathrm{e}}\right) \& \mathrm{e}$ causa $\mathrm{e}^{\mathrm{ee}}$

$\exists \mathrm{e}^{\text {eeee }} \operatorname{correr}\left(\mathrm{e}^{\mathrm{ecee}}\right.$, joão $\left.)\right)$

$\therefore \exists \mathrm{e}^{\text {ecees }}$ queima-de-caloria( $\left.\mathrm{e}^{\text {eceee }}\right){ }^{92}$

A quantificação universal explícita - na primeira premissa- sobre eventos de correr é articulada logicamente com a quantificação existencial implícita sobre eventos na segunda premissa. O tratamento com eventos explicita a conclusão inferida das duas premissas. Se todo evento de correr provoca um evento de queima de caloria, e existiu um evento de João correr, conclui-se que ocorreu um evento de caloria ser queimada. ${ }^{93}$

Do que foi mostrado até agora segue-se que, se as formas lógicas acima para sentenças de ação estiverem corretas, todo o aparato de reificação e referência disponível nas línguas naturais: quantificação, pronomes, descrições definidas e indefinidas, enunciados de identidade, contagens,

\footnotetext{
${ }^{91}$ Exemplo adaptado de Lepore \& Pelletier (2007).

92 Como evidenciado na representação semiformal, apresentamos a possibilidade de tratar um evento de correr como causa de um outro evento, a saber, evento de queimar (gastar) caloria.

${ }^{93}$ Como ficará evidenciado na subseção 2.5 .2 , relações causais serão mobilizadas para a formulação davidsonina de um critério geral de individuação de eventos.
} 
etc., são empregados também para descrever e se referir a eventos. O que significa que, ao reificar eventos, aparentemente motivados por nossa própria linguagem, tratando-os como entidades que percorrem o domínio de variáveis ligadas por quantificação, nos comprometemos com a existência de eventos como entidades particulares que pertencem à ontologia do discurso ordinário. Além de pessoas e objetos físicos povoando o mundo, haveria eventos. Sobre isso sublinha Davidson em "Events as Particulars" ${ }^{94}$ :

[...] Se aceitarmos essas expressões e sentenças como tendo a forma lógica que elas aparentam ter, então estamos comprometidos com uma ontologia de eventos como particulares que não se repetem (,indivíduos concretos ${ }^{\circ}$ ). São a esses eventos que nos referimos, ou pretendemos nos referir, quando usamos descrições como ,a morte de Montiverdiee, ,sua segunda entrevista depois do julgamento na noite anterior"; são de eventos como esses que [...] asserimos a existência quando dizemos ,teve uma festa barulhenta no apartamento de Gwen na última semana ${ }^{\text {ec }}$ [...] são eventos desses tipos sobre os quais quantificamos em „Todas as guerras são evitáveis” e „Nem toda mentira tem más consequências"(Davidson 2011 [1970]: 181).

A tese central de que eventos são necessários para a especificação adequada da forma lógica das sentenças de ação modificadas por advérbios é fortalecida por evidências linguísticas sugeridas pela própria superfície das línguas naturais. Por outro lado, é a postulação de eventos como argumentos ligados por quantificação encoberta em sentenças como „Pedro beijou Maria no parque pela manhã às $9 \mathrm{~h}^{\mathrm{ee}}$, fornecendo uma forma lógica que exibe o encadeamento de interdependência logica entre (1-4), que garante que a hipótese de eventos não se apoie unicamente nos mecanismos explícitos de descrição e referência presentes nas línguas. Isso porque o aparato de reificação na linguagem coloquial aparenta não ter limites definíveis quanto ao que tomar como "entidades". Lembremos que os mesmo artifícios são empregados, por exemplo, para falar sobre significados ("o significado de ,automóvel é é...”, ,esse significado corresponde ao primeiro significado que você tinha em mente ${ }^{e e}$,,algum significado não foi mencionadoe, etc), ou para reificar termos gerais (,a felicidade é uma benção ${ }^{e e}$, „a alegria de Paulo foi enorme, ela contagiou a classe ${ }^{e e}$, „todo amizade é bem vinda ${ }^{e e}$, etc). E nem por isso introduzimos tais entidades em nossa teoria. O que mostra que não é a mera observação da superfície das sentenças que encoraja Davidson a tomar eventos como entidades do nosso universo de discurso. Afinal, "aprendemos a ser cautelosos [...] com o que a superfície da linguagem sugere, especialmente quando se trata de ontologia” (Davidson 2011 [1970]: 181). Pelo contrário. É o fato de que redes inferenciais entre sentenças de ação e sentenças que indicam relações causais "podem ser explicadas tratando-as como tendo uma estrutura quantificacional não

\footnotetext{
${ }^{94}$ Artigo publicado pela primeira vez na revista Nous 4, 1970, editada pela Wayne State University, Detroit, Michigan. Ele aparece como artigo 9 no livro Assays on Actions and Events, segundo volume das obras de Davidson.
} 
aparente na superfície" (Davidson 1990[1977]: 210-11), e que quantifica sobre eventos, a justificativa principal para que a teoria adote uma ontologia de eventos. O que está aos olhos de todos, por assim dizer, é mencionado para reforçar a hipótese e mostrar que ela pode ser empregada para cobrir outros fragmentos das linguas naturais.

Essas considerações colocam duas questões importantes sobre o projeto de Davidson e que pedem alguma elucidação aqui. Em primeiro lugar, um esclarecimento da relação entre forma lógica e notações canônicas em uma teoria semântica. E, em segundo lugar, entre quantificação e ontologia em uma teoria da verdade. Na subseção que se segue esboçarei alguns comentários que espero que iluminem aspectos dessas duas questões.

\subsection{Quantificação, Ontologia e Forma Lógica.}

$\mathrm{Na}$ caracterização de um predicado de verdade para um fragmento de linguagem que contenha apenas um número finito de nomes, predicados e conectivos verofuncionais (conjunção, disjunção, negação, etc), por exemplo, não há nada que impeça que se forneça as condições de verdade das sentenças atômicas diretamente, i.e., tomando a lista finita de sentenças atômicas como o vocabulário básico da linguagem sob investigação. Neste caso, “[...] as próprias sentenças-T poderiam servir de axiomas" (Davidson 1990[1977]: 206), e a parte recursiva ficaria circunscrita aos mecanismos responsáveis por construir sentenças a partir de sentenças, i.e., os conectivos lógicos. Isso porque, dado que haveria somente uma lista finita de nomes e predicados, conclui-se que existiria apenas um conjunto finito de sentenças básicas. A possibilidade de tratar, em uma teoria da verdade, um fragmento composto somente de nomes e predicados como uma lista finita de sentenças, sem a necessidade de entrar na estrutura interna das mesmas, indica que uma teoria satisfatória para uma linguagem sem estruturas quantificacionais não requer comprometimentos ontológicos além da existência de sentenças. Entretanto, quando uma linguagem apresenta estruturas semânticas mais complexas, em especial mecanismos de quantificação, a questão da ontologia da linguagem objeto entra em cena, pois o tratamento das expressões quantificacionais em uma teoria da verdade exige que se estabeleçam relações sistemáticas entre as expressões da linguagem e objetos. Observa Davidson, em "The Method of Truth in Metaphysics":

A questão da ontologia é forçada a aparecer somente onde a teoria encontra estrutura quantificacional, e aqui é onde a teoria melhor explica o padrão de dependências de verdade relacionando sistematicamente expressões a objetos. Enquanto nossa atenção é focada sobre sentenças simples, podemos nos perguntar por que uma explicação da verdade deveria ter na ontologia termos singulares mais do que predicados. A classe dos objetos sábios (ou a propriedade da sabedoria) ofere-se como o que poderia corresponder ao predicado „sábio em "Sócrates é sábio“e da mesma forma que Socrates corresponde a ,Socrates ${ }^{e e}$ [...] Nenhum número finito de tais sentenças requer que uma teoria da verdade introduza ontologia. Quando encontramos [...] 
quantificação e predicados de qualquer grau de complexidade, contudo, o quadro muda. Com estrutura quantificacional complexa a teoria combinará expressões com objetos. Mas não há necessidade, contanto que a lógica subjacente seja de primeira ordem, de introduzir entidades que correspondam a predicados. O reconhecimento desse fato certamente não resolverá o problema de se existem coisas como universais ou classes. Mas ele demonstra que há uma diferença entre termo singular e predicado; pois, de qualquer maneira, para grandes extensões da linguagem variáveis, quantificadores e termos singulares devem ser construídos como tendo função referencial; não sendo o mesmo para predicados (Davidson 1990 [1977]: 210).

É a estrutura quantificacional das sentenças de uma linguagem objeto que revelará a ontologia desta linguagem. Lembrem que o conceito de satisfação é introduzido por Tarski como um método que permite caracterizar verdade para as sentenças de uma linguagem via a atribuição sistemática de condições de satisfação para as expressões que compõem as sentenças: quantificadores, predicados e nomes (caso a linguagem contenha nomes). É a presença de expressões que quantificam sobre objetos acerca dos quais a linguagem fala que justifica o emprego do conceito de satisfação como uma relação entre expressões da linguagem e objetos. Nessa estratégia, os únicos objetos assumidos são os que são percorridos pelas variáveis das expressões linguísticas. De maneira que o comprometimento ontológico recai sobre os objetos que as cláusulas de satisfação atribuem às variáveis. E, uma vez que a o conceito de satisfação ilumina como que as constantes lógicas operam estruturalmente, relacionando funções predicativas e sequências de objetos, na especificação das condições de verdade das sentenças em que elas parecem, a teoria fornece uma explicação composicional de como as estruturas quantificacionais das sentenças determinam padrões de inferências. Em nenhuma etapa da teoria é necessário, para caracterizar a composicionalidade do significado das sentenças, postular qualquer entidade correspondendo às funções predicativas. Basta relacionar as variáveis dos predicados aos objetos que elas percorrem. O que não implica que uma teoria da verdade à lá Tarski soluciona o problema da existencia de propriedades, universais. Se Davidson mantivesse tal posição, ele estaria sem dúvida inferindo mais do que a teoria fornece. $\mathrm{O}$ que a teoria mostra é que para amplos fragmentos de uma língua natural é possivel fornecer uma teoria composicional sem assinalar entidades abstratas às expressões predicativas.

O que deve ficar bastante claro, e o fragmento acima em certa medida elucida isso, é que Davidson entende que a existência de nomes por si não força a teoria a empregar a relação de referência entre partes da linguagem e fragmentos do mundo. Isso porque, como já sugerimos, é a estrutura quantificacional que exige a substituição de uma teoria que simplesmente disponibiliza uma lista de axiomas da forma ,s é verdadeira $\leftrightarrow p^{\text {ee }}$, por uma que, mediante o emprego da noção de satisfação, fornece para as expressões da linguagem, em especial os predicados e quantificadores, axiomas da forma,$\forall f\left(f \operatorname{satisfaz}_{(\mathrm{r}, \mathrm{t})} \ldots \leftrightarrow \ldots f \ldots\right)^{\mathrm{ee}}$. É, por assim dizer, no ponto em que as sentenças de uma linguagem objeto, à luz da teoria, exigem que as suas condições de verdade só podem ser 
explicadas se se vislumbrar um método de gerá-las com base na análise da sua estrutura e das propriedades semânticas das partes, que a teoria começa a lidar com a questão da ontologia da linguagem objeto.

Mas a quantificação nas línguas naturais nem sempre parece estar imediatamente expressa em termos realizados na superfíce das sentenças e que operam como quantificadores. No processo de capturar em uma teoria da verdade estruturas que determinam relações de implicação entre sentenças de um dado tipo, algumas vezes a postulação de operações quantificacionais subjacentes mostra-se uma estratégia com um poder explicativo inegável. Há casos em que "uma sentença cumpre um papel que pode ser explicado somente tratando-a como possuindo uma estrutura não aparente na superfície" (Davidson 1990[1977]: 211). A descrição das sentenças de ação como possuindo uma forma lógica que introduz quantificação existencial sobre eventos, como examinado na subseção 2.3.1, possibilitou dar uma explicação, em conformidade com os critérios reguladores de uma teoria do significado ${ }^{95}$, de como que os significados das sentenças de ação dependem da sua estrutura composicional. $\mathrm{O}$ apelo à quantificação sobre eventos ilustra um ponto crucial: a questão de quando é necessário exibir na teoria a forma lógica de determinadas sentenças recorrendo, por assim dizer, a estruturas não observáveis. Esta necessidade está vinculada ao entendimento de que a interdependência de significado entre diversos conjuntos de sentenças, observadas nas inferências entre elas, indica a existência de articulações lógicas entre as suas estruturas e que, por isso, uma análise do significado dessas sentenças deve capturar essas estruturas. É neste contexto que a questão da forma lógica assume uma centralidade no projeto davidsoniano. E para compreendermos o papel que cumpre a noção de forma lógica na semântica de Davidson devemos distinguir entre a sua definição geral de forma lógica e as tentativas de especificar para classes específicas de expressões quais são suas formas lógicas.

Há duas passagens de distintos textos nas quais Davidson expõe de maneira bastante precisa o que ele entende por forma lógica. A primeira aparece em "On Saying That", a segunda em "Criticism, Comment, and Defence" ${ }^{96}$. Vejamos ambas:

O que devemos exigir de uma explicação adequada da forma lógica de uma sentença? Sobretudo, eu diria, tal explicação deve nos levar a ver o caráter semântico da sentença - sua verdade ou falsidade - como devido a como ela é composta, por um número finito de aplicações de algum número finito de mecânismos suficientes para a linguagem como um todo, a partir de elementos extraídos de um estoque finito (o vocabulário) suficiente para a língua como um todo. Ver uma sentença sob esta perspectiva é vê-la à luz de uma teoria para essa linguagem, uma teoria que fornece a

\footnotetext{
${ }_{95}^{95}$ Ver Capítulo I para uma exposição pormenorizada desses critérios.

${ }^{96}$ Este texto é um conjunto de respostas de Davidson a críticas de interlocutores às suas teses sobre eventos e ações. Ele está em Essays on Actions and Events.
} 
forma de toda sentença naquela linguagem. Uma maneira de fornecer essa teoria é por meio de uma caracterização recursiva de um predicado de verdade, na linha sugerida por Tarski (1990[1968]: 94).

[...] tudo o que significo ao dizer que ,Jones buttered the toast" tem a forma lógica de uma sentença quantificada existencialmente, e que ,buttered é é um predicado de três lugares, é que uma teoria da verdade que satisfaz o critério de Tarski implicaria que essa sentença é verdadeira se e somente se existe... etc. [...] Fornecemos a forma lógica de uma sentença quando fornecemos as condições de verdade da sentença no contexto de uma teoria da verdade aplicada à linguagem como um todo. Tal teoria deve identificar algum estoque finito de elementos relevantes para a verdade das sentenças, e, explicitamente, explicar cada sentença com base em como seus elementos operam nela; então, fornecer a forma lógica de uma sentença é descrevê-la como composta de elementos que a teoria isola" (2011[180]: 143).

A forma lógica de uma sentença é a estrutura a ela atribuída no curso de fornecer uma sentença-T para ela como consequência de uma teoria da verdade para o fragmento de linguagem do qual a sentença faz parte. Ela será a forma semântica que a sentença exibe à luz de uma teoria da verdade. Ao revelar a forma lógica de uma sentença $s$ qualquer "no contexto de uma teoria da verdade", revela-se, simultaneamente, como a forma lógica é composta pela contribuição semântica dos termos que formam a sentença. Mas como isso se dá? Recordem que a solução para (1-4) em termos de quantificação sobre eventos exibe a contribuição do verbo „,beijar ${ }^{\text {ee }}$ nas quatro sentenças. A teoria especifica „beijaree como um primitivo semântico, um predicado de três lugares, em que um dos argumentos é um evento. Numa teoria axiomática, „beijar ${ }^{\text {ee }}$ recebe uma cláusula de satisfação que exibe a sua adicidade e a estrutura que esse predicado compartilha com todos os outros predicados de três lugares que pedem um argumento para evento. Do ponto de vista da teoria, os próprios termos primitivos que a teoria especifica possuem uma forma lógica, e ela é exibida nos axiomas de satisfação que se atribui aos termos. Nesse sentido, a forma lógica de ,beijare é justamente a estrutura que ela partilha com outros verbos de ação. Estrutura essa que também determina como que „beijar ${ }^{e e}$ interage com as outras expressões da linguagem que possuem estruturas distintas; por exemplo, como que interage com nomes e quantificadores. Exibir a "forma lógica de uma sentença quando fornecemos as condições de verdade da sentença no contexto de uma teoria da verdade aplicada à linguagem" significa apresentar a forma lógica das sentenças nas sentenças-T geradas composicionalmente. Por exemplo: uma vez que todos os axiomas de satisfação para verbos como „,beijarce possuem uma forma comum, que é o que caracteriza a forma lógica desses verbos, as condições de verdade de „Pedro beijou Maria ${ }^{\text {e }}$ „Pedro Abraçou Maria“e geradas pela teoria também mostram a forma lógica que ambas as sentenças partilham.

Pode-se dizer que Davidson enxerga a forma lógica de um termo como uma espécie de categoria semântica. Sob uma tal descrição, a forma lógica dos predicados „,beijare e ,abraçare seria algo como , $\Phi(\mathrm{e}, \mathrm{x}, \mathrm{y})^{\mathrm{e}}$, ou seja, um predicado ternário, com dois argumentos para indívíduos e um 
para evento. É fácil de ver aqui que isso claramente define toda uma classe de expressões. Consequentemente, uma teoria da verdade para o fragmento de uma língua, ao mesmo tempo em que fornece as condições de verdade de uma sentença $s$ como uma função das condições de satisfação das suas unidades constitutivas, informa também a forma lógica de $s$. Como resultado, quando uma forma lógica atribuída a uma sentença $s$ contém estrutura quantificacional, e, portanto, constante(s) lógica(s), imediatamente é fácil de perceber como que uma especificação das condições de verdade que esteja em conformação com a forma lógica da sentença revela as estruturas relevantes para determinar inferências. No caso das inferências em (1-4), o que realmente importa são as propriedades que o verbo „beijar"e compartilha com os outros verbos de ação e a quantificação existencial que sentenças com esses verbos introduzem. Tanto é que a forma lógica de (1-4) pode ser exibida sem empregar as expressões que ocorrem em (1-4), tomando „Ф $\Phi^{e e}$ como uma

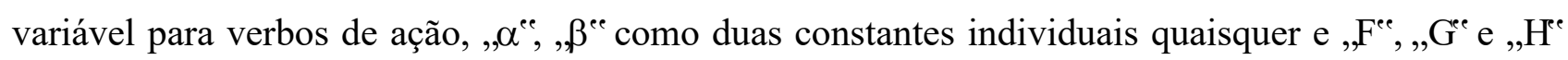
como abreviações para três predicados quaisquer de eventos:

i. $\exists$ e: $\Phi(\mathrm{e}, \alpha, \beta) \& \mathrm{~F}(\mathrm{e}) \& \mathrm{G}(\mathrm{e}) \& \mathrm{H}(\mathrm{e})$.

ii. $\exists$ e: $\Phi(\mathrm{e}, \alpha, \beta) \& \mathrm{~F}(\mathrm{e}) \& \mathrm{G}(\mathrm{e})$.

iii. $\exists \mathrm{e}: \Phi(\mathrm{e}, \alpha, \beta) \& \mathrm{~F}(\mathrm{e})$.

iv. $\exists \mathrm{e}: \Phi(\mathrm{e}, \alpha, \beta)$.

Seguem-se das considerações gerais de Davidson sobre forma lógica numa teoria do significado e da sua argumentação em defesa da sua solução particular para as sentenças de ação, três critérios cruciais para testar a adequação de uma forma lógica fornecida pela teoria: (i) exibir estruturas suficientes que validam inferências percebidas entre sentenças sob o escrutínio da teoria; (ii) a forma lógica de uma sentença deve ser determinada pela forma lógica dos itens lexicais que a formam; e (iii) as formas lógicas fornecidas não podem conflitar com o princípio de aprendizagem. Notem que os critérios (i-iii) são versões, para o caso das formas lógicas, das condições elaboradas em TMLL. É esta conexão que assegura que a investigação da forma lógica de sentenças de uma linguagem seja empreendida "à luz de uma teoria do significado para essa língua” e, portanto, em conformidade com condições que regulam a forma geral de uma teoria composicional do significado. E a forma lógica proposta por Davidson para as sentenças de ação e de relações causais respeita rigorosamente os três critérios mencionados.

Davidson expõe a forma lógica das sentenças de ação por meio de paráfrases em uma linguagem quantificacional de primeira ordem. Esse recurso levanta uma questão: qual a função que o emprego de uma lógica de primeira ordem, que possui sua própria semântica, desempenha em 
uma teoria da verdade para uma língua natural? Davidson argumenta em defesa desse mecanismo de paráfrase da seguinte maneira:

[...] uma vez que não estou interessado em aperfeiçoar a linguagem natural, mas em compreedê-la, eu vejo linguagens formais ou notações canônicas como mecanismos para explorar a estrutura da língua natural. Sabemos como fornecer uma teoria da verdade para a linguagem formal; portanto, se também soubéssemos como trasnformar as sentenças de uma língua natural sistematicamente em sentenças de uma linguagem formal, teríamos uma teoria da verdade para a língua natural. Desse ponto de vista, linguagens formais padrões são mecanismos intermediários que nos ajudam a tratar línguas naturais como linguagens formais mais complexas (Davidson 1990 [1977]: 203).

Uma série de posições são condensadas nesta reflexão de "The Method of Truth in Metaphysics". Em primeiro lugar, Davidson se preocupa mais uma vez em sublinhar que não pretende utilizar métodos formais como instrumentos para iluminar as "imperfeições" das línguas formais e, por meio disso, elaborar uma línguagem formal purificada e com uma semântica precisa. Com isso, Davidson quer se distanciar das posturas de Frege e Quine a respeito das linguagens regimentadas. A diretriz do projeto consiste em empregar a regimentação "como parte de uma teoria" (idem) das línguas naturais. Como isso se dá? Davidson sugere que, uma vez que Tarski mostrou como construir uma teoria da verdade para uma linguagem formal, e dada a precisão semântica dessas linguagens, se conseguirmos especificar as condições de verdade das sentenças de uma língua natural em uma linguagem para a qual já se tem uma teoria, teremos um método sistemático de estender uma teoria da verdade para fragmentos das línguas naturais. Considerem a paráfrase de (14) na forma quantificacional. Os acarretamentos entre sentenças que dependem fundamentalmente de estruturas quantificacionais podem ser formalizados. Ao se sugerir que as inferências em (1-4) podem ser articuladas, via notação canônica, em uma estrutura formal como (i-iv), fornece-se uma método para testarmos, no escopo de uma teoria da verdade, se uma forma lógica hipotetizada para uma classe de sentenças de uma língua natural acomoda as inferências que os falantes reconhecem no emprego dessas sentenças. Ao colocar as sentenças de ação e sobre relações causais na forma de uma estrutura quantificacional, possibilitamos que uma teoria composicional do significado da forma proposta seja aplicável a essas sentenças. Essa estratégia de mobilizar a lógica de quantificação de primeira ordem "como um mecanismo intermediário" para auxiliar na atribuição de estruturas semânticas a sentenças de uma língua natural, revela-se inclusive um instrumento poderoso para capturar ambiguidades estruturais de sentenças. Tomemos a seguinte sentença:

19. Todo homem na festa foi beijado por uma mulher. 
Tal sentença permite ao menos duas interpretações: $(\alpha)$ que cada homem na festa foi beijado por uma mulher distinta; ou ( $\beta$ ) que uma única mulher beijou todos os homens na festa. Na ampla literatura sobre o comportamento sintático e semântico de expressões das línguas naturais que aparentam operar como quantificadores é bastante compartilhada a hipótese de que sentenças como (19) são semanticamente ambíguas em função das possíveis interações de escopo entre suas expressões quantificacionais. Em (19) tais expressões são „todo homeme e „uma mulher. O que se sugere é que quando a interação entre os quantificadores respeita a ordem em que aparecem explicitamente na sentença, a interpretação de (19) é ( $\alpha$ ). Já quando „uma mulher é interpretada como tendo escopo sobre „todo homem“, a interpretação é ( $\beta$ ). Se essa forma de explicar a ambuiguidade de (19) for correta, o que parece estar em jogo é que nem sempre o significado de uma sentença espelha o ordenamento realizado dos seus constituíntes. De maneira que (19) pode ser compreendida como tendo, na verdade, duas fórmas lógicas. Ou podemos dar um passo além, e sustentar que, da mesma maneira que posso tomar palavras ambíguas, como „banco dois termos primitivos que são realizados foneticamente por um mesmo conjunto de sons, que (19) pode realizar duas estruturas sentenciais, e que somente o contexto em que (19) é enunciada é que dirá qual estrutura está operando. Uma lição que se depreende de sentenças como (19) é que muitas sentenças não podem ser diretamente analisadas pela teoria. Elas só podem ser adequadamente interpretadas pela teoria semântica depois de serem transformadas (traduzidas) em sentenças que explicitam seus possíveis significados. Por exemplo, se tenho um método de mapear (19) em duas formas lógicas, automaticamente posso gerar as duas condições de verdade possíveis de (19). Basta que a teoria, em vez de operar diretamente sobre (19), interprete as formas lógicas possíveis de (19) exibidas em uma linguagem regimentada. No nosso exemplo, a teoria deve fornecer duas sentençasT para (19). As duas paráfrases em questão em uma linguagem de quantificação de primeira ordem seriam

$$
\begin{aligned}
& 19^{\text {ee }} . \forall \mathrm{x}: \operatorname{homem}(\mathrm{x}) \rightarrow \exists \mathrm{y}: \operatorname{mulher}(\mathrm{y}) \& \operatorname{beijou}(\mathrm{y}, \mathrm{x}) . \\
& 19^{\text {ceee }} \exists \mathrm{y}: \operatorname{mulher}(\mathrm{y}) \& \forall \mathrm{x}: \operatorname{homem}(\mathrm{x}) \rightarrow \operatorname{beijou}(\mathrm{y}, \mathrm{x}) .
\end{aligned}
$$

O mecanismo de transformar sentenças de uma língua natural em sentenças (semi)-regimentas antes de submetê-las à interpretação em uma teoria semântica parece essencial se o que se espera é que métodos semânticos formais possam ser aplicados para a investigação das línguas naturais. Mas essa postura inevitavelmente induz a questão: mediante esse processo de regimentação não se estaria, de alguma forma, impondo a lógica da linguagem de predicados sobre uma língua natural? Em certa medida esta questão não parece ser um problema para Davidson. Retomando um ponto 
que levantamos na subseção 2.1 deste capítulo, a lógica e os conceitos semânticos empregados por uma teoria da verdade cumprem a função de descrever, do ponto de vista da teoria, o que é observável: enunciados em contextos de uso. A pergunta mais apropriada a se fazer, da perspectiva de Davidson, é: as estruturas não "observadas diretamente" que se atribuem às sentenças em uso são satisfatórias no sentido de fornecerem composicionalmente as condições de verdade dessas sentenças em uso? Para o projeto semântico davidsoniano, não há uma questão a respeito da correção de uma lógica e conceitos semânticos mobilizados além da pergunta de se eles contribuem para capturar as possíveis interpretações de uma sentença. Forma lógica, assim entendida, "será relativa à escolha de uma metalinguagem (com sua lógica) e a uma teoria da verdade" 1990[1973]: 71). Não há nada que impeça de antemão que diferentes teorias composicionais, com diferentes metalinguagens, lógicas e notações, capturem as condições de verdade de um mesmo conjunto de sentenças.

Para apreciar a noção de Davidson de forma lógica, é essencial atentar para o fato de que o projeto de fornecer as formas lógicas de um conjunto de sentenças semanticamente interdependentes, portanto, não se limita meramente a explicitar como uma rede inferêncial depende da forma das sentenças envolvidas. Essa é uma condição necessária, mas não suficiente. A enfase, central em Davidson, na prescrição de que a forma lógica de uma sentença, repito, é a forma atribuída no corpo de uma teoria do significado, que, por sua vez, é a forma associada a ela via uma teoria interpretativa da verdade, impõe sobre a elaboração das formas lógicas as mesmas condições que regulam uma teoria do significado para uma dada língua. Se elas não excluem de todo a possibilidade de que a forma lógica seja indeterminada, no sentido de poder haver formas lógicas não equivalentes que cobrem os mesmos dados, elas ao menos parecem reduzir essa indeterminação ao demandar que as formas lógicas estejam em conformidade com as condições gerais que devem regular uma teoria semântica para línguas naturais. Somado a isso, não se pode esquecer também o princípio metodológico de sempre optar pela explicação mais simples, elegante e parcimoniosa.

Sintetizando. As formas lógicas de uma língua natural $\mathrm{L}^{*}$ qualquer, por exemplo, são abstrações a partir da intuição dos falantes de $L^{*}$ acerca das relações de inferência entre sentenças, à luz de uma teoria do significado. Isso implica que as formas lógicas atribuídas a um conjunto $\mathrm{C}$ de sentenças de $\mathrm{L}^{*}$ devem permitir que uma teoria do significadof orneça uma interpretação composicional dessas sentenças e que capture as relações lógicas entre elas. Não há necessidade para esse empreendimento da prerrogativa de que haja uma única e correta forma lógica a ser associada a uma sentença. Em princípio, não há problemas em capturar o que Davidson chama de "localização semântica" de uma sentença - ou seja, os padrões de inferência que ela estabele com outras sentenças - mediante diferentes caminhos. Obedecidas as condições mencionadas, não há 
nada que impeça que a mesma intuição de um falantes de L* possa ser representada de maneiras distintas.

\subsection{Desafios ou limites à solução em termos de eventos.}

Até agora apenas exibimos as benesses da semântica de eventos e dos advérbios como predicados de eventos proposta por Davidson. Mas tal solução apresenta problemas também. Se aplicada de forma generalizada, a análise para os advérbios pode produzir consequências que não capturam a semântica de uma classe de sentenças de ação. Qual é esse problema? Como elucidamos na subseção 2.3.1, uma vantagem da análise é que nela os modificadores adverbiais são tratados como predicados dos eventos introduzidos pelos verbos de ação, de modo que a inferência de „João beijou Maria ${ }^{e e}$ a partir de „João beijou Maria no parque ${ }^{e e}$ recebe uma explicação puramente extensionalista. Todavia há uma classe de modificadores adverbiais que parece resistir a serem acomodados numa semântica extensional. Tomemos o advérbio ,propositadamente ${ }^{\text {ee }}$ e olhemos para as seguintes sentenças:

20. Pedro abraçou Joana propositadamente.

21. Joana é a irmã de Maria.

23. Pedro abraçou a irmã de Maria propositadamente.

Se forneço uma forma lógica para (20) da maneira sugerida pela análise de eventos, sou forçado a concluir que a verdade da conjunção de (20) e (21) necessariamente implica a verdade de (23). Mas suponha que Pedro não saiba que Joana é a irmã de Maria, tampouco conheça Maria e ainda, para ser mais ilustrativo, tem a crença falsa de que Joana é filha única. Neste contexto, embora a verdade da sentença (20) acarrete que João beijou a Irmã de Maria, ela não implica a sentença (23), pois neste caso esta é falsa: Pedro não teve a intenção de abraçar ,a irmã de Maria ${ }^{e e}$,já que ele não atribui esta descrição a Joana. Advérbios como „,propositadamente ${ }^{e e}$, ,intencionalmente ${ }^{e e}$, ,deliberadamente ${ }^{e e}$, etc., parecem, tal como verbos de atitude proposicional e operadores modais, criar contextos intensionais, i.e., em que a substituição de termos com a mesma extensão não assegura a preservação do valor de verdade.

A análise em termos de eventos não funciona para uma classe de advérbios - em especial os que indicam volição do agente de uma ação - que parecem criar contextos semanticamente opacos. Tais advérbios parecem não operar como os advérbios de tempo, espaço, instrumento, etc. O que é específico de sentenças como (20) é que elas não simplesmente descrevem uma ação, um evento, mas indicam a forma em que o agente "vê" a sua ação, a intencionalidade com a qual ela é 
empreendida. Um caminho para explicar esses advérbios é tratá-los como modificando proposições, os conteúdos veiculados pelas sentenças. Todavia, essa alternativa introduz conceitos que uma semântica rigorosamente davidsoniana quer evitar. Ainda que reconheça os limites da sua análise para acomodar tais advérbios, Davidson não ensaiou ou esboçou uma solução para eles no corpo da sua teoria semântica.

A lição e o progresso que fica é que ao menos se tem uma maneira de distinguir advérbios que podem ser facilmente acomodados em uma semântica de eventos daqueles que não podem. Mas presumivelmente isso não deve ser tudo o que se consegue fornecer. Ainda falta para uma semântica que pretende não recorrer a conceitos como proposição capturar essa classe de advérbios e sentenças de ação nas quais eles ocorrem.

\subsubsection{Eventos e ontologia.}

A solução de eventos funciona para uma ampla classe de sentenças, mas é um mecanismo que "precisa de uma ontologia para fazê-lo funcionar: [...] uma ontologia de eventos para „Jones cortou sua bochecha no banheiro sábado ${ }^{e e ’ "}$ (Davidson 1990 [1977]: 212-213). A introdução de eventos reificados na forma lógica configura-se como uma alternativa que, como vimos, evita problemas que outras soluções acarretam. A quantificação sobre eventos como argumentos de uma classe de verbos permitiu acomodar as sentenças de ação e causais em uma teoria semântica que obedece às condições expostas no capítulo I. Entretanto, Davidson pondera que, além da utilidade teórica de uma semântica de eventos, a sua adoção de imediato revelaria que, se correta a forma lógica sugerida para "sentenças sobre mudança, então a menos que existam eventos, não há sentenças verdadeiras dos tipos comuns sobre mudança. E se não há sentenças verdadeiras sobre mudança, não há sentenças verdadeiras sobre objetos que mudam” (Davidson 1990 [1977]: 214). O comprometimento com a verdade de sentenças sobre mudança necessariamente imporia o comprometimento com a existência de eventos.

Comprometer-se, entretanto, com a existência de pessoas e montanhas, por exemplo, parece, intuitivamente, não ser a mesma coisa do que se comprometer com eventos como objetos quantificáveis. Eventos mudam pessoas e objetos físicos. Por essa razão, temos de enfrentar, se queremos brincar seriamente de fazer ontologia, questões que sugerem a si mesmas: quantificar sobre pessoas e montanhas, nas estruturas de nossa linguagem, é o mesmo que quantificar sobre eventos? „Existe um objeto x, tal que... x...” tem o mesmo significado que „Existe um evento $e$, tal que ...e...ee? A questão está nos tipos de objetos quantificados ou no significado do operador existencial? Haveria mais de um significado para o operador existencial? 
No quadro que emerge da proposta davidsoniana, quando quantificamos sobre pessoas, objetos físicos e eventos estamos empreendendo um mesmo mecanismo de reificação: fixando os objetos dos universos admissíveis no aparato referencial de nossa linguagem. Via notação do cálculo de predicados, na qual a quantificação é um mecanismo para falar de objetos em geral, Davidson, justamente, procura assumir eventos como entidades do universo ôntico da linguagem. Entidades que, como qualquer entidade sobre a qual se pode falar, são percorridas pelas variáveis presas por quantificadores. Eventos contam como valores das variáveis de quantificação implícitas nos verbos de ação. Mas disso não se pode apressadamente concluir que Davidson sustente que, por reificarmos eventos, pessoas, montanhas, tais objetos, em nosso universo de discurso, são concebidos como compartilhando uma mesma estrutura interna e como tendo as mesmas condições de individuação. Quantificar sobre evento é assumir evento como entidade particular da nossa ontologia, mas pouco diz sobre a natureza interna desse tipo de entidade.

É nesse ponto, em que a investigação semântica detalhada nos conduziu a um "impasse" ontológico, que entendo fundamental retornar a Quine - cuja ideia de que ser consiste em ser o valor de uma variável foi fonte motivadora do empreendimento davidsoniano de se extrair consequências ontológicas de uma semântica correta - para ponderar mais atentamente sobre como o autor concebe o processo de reificação em teorias e esquemas conceituais e investigar o debate que ele travou com Davidson sobre reificação de eventos.

Em Word and Object (1960) e „On What There Is ${ }^{e e}(1960)$, Quine argumenta que nem tudo a que nossa linguagem, em princípio, parece se referir impõe de imediato um comprometimento ontologico. Exemplo disso é como Quine mostra que se pode eliminar via análise o comprometimento com a existência de seres ficcionais, propondo reescrever os nomes próprios como descrições definidas, tornando um nome ficcional um predicado. Com isso, o nome Pégasus é reescrito como „o único x, tal que x pegasiza ${ }^{e e}$. Sob tal interpretação, dizer que Pégasus não existe significará apenas dizer que a extensão do predicado pegasiza é vazia. O que não é um problema, pois não é nenhuma contradição dizer que existem descrições sem extensão. Interpretando Pegasus “como uma descrição sujeita à teoria das descrições de Russell [...] nos livramos da antiga noção de que não se pode dizer que Pégasus não é sem se pressupor em algum sentido que Pégasus é” (Quine 2004 [1960]: 183). Embora em Quine a existência de entidades seja sempre relativa a uma teoria, linguagem ou esquema conceitual, não se deve, de imediato, disso inferir que tudo o que uma linguagem parece assumir como objetos, i.e., tudo o que parece ser reificado no interior de uma linguagem, de pronto pertence à sua ontologia. "Pois qualquer um com escrúpulos sobre quais objetos ele assume" (Quine 2004 [1960]: 120) deve atentar para “a distinção entre reificação irresponsável e seu oposto" (idem). 
Mas o que caracterizaria então uma "reificação responsável”? A prescrição de Quine é que se só devem ser admitidas entidades para as quais é formulado um critério geral adequado de identidade, i.e., que garante a individuação de uma entidade. As coisas são idênticas, no sentido aristotélico, quando possuem as mesmas propriedades, i.e., o que quer que se predique de uma deve, necessariamente, predicar-se da outra. Por conseguinte, não podemos saber o que algo é sem saber como ele se distingue das outras coisas, "até onde você tem a mesma maçã e quando você obtém outra" (Quine 2004 [1960]: 115). Nesse sentido, o princípio de identidade só deve valer para as entidades para as quais é formulado um critério de identidade que dê as condições para se afirmar e negar identidade. A princípio, parece que temos esse critério para os objetos físicos, entidades modificadas por eventos. Dois objetos físicos são idênticos se, e somente se, ocupam a mesma porção do espaço-tempo. Mas o que asseguraria a individuação de um evento? Como fazer o princípio de identidade valer para um evento? Quais são as condições que garantem que um evento seja igual a si mesmo? Penso que o critério quineano de admissibilidade ontológica i.e., de que não há entidade sem identidade, seja uma bússola criteriosa na investigação das relações entre linguagem e ontologia. Mas a revisão de nossa ontologia deve ser empreendida quando "temos mecanismos substitutos prontos à mão que servirão ao mesmo propósito essencial” (Quine 1960: 124), como no caso em que nomes ficcionais são reescritos como predicados. Ou seja, a busca por uma regimentação que "simplifique" nossa ontologia, i.e., que corte com a navalha de Ockham "pseudo-entidades" (uma demanda metodológica interessante à qual se ater, para não sairmos por ai postulando irrestritamente entidades), precisa também dar conta dos dados que uma ontologia mais complicada conseguiu caracterizar rigorosamente. Tendo em vista a necessidade de um critério de identidade para se assumir uma entidade como pertencente à nossa ontologia, talvez o melhor percurso para se adotar uma ontologia seja atentar para a convergência entre poder explicativo, formulação de um critério de identidade e simplicidade. Prescrições muito em acordo com uma prática de investigação rigorosa e atenta. Tendo em perspectiva a prescrição quineana expressa na máxima não existe entidade sem identidade, Davidson, no artigo "The Individuation of Events", de $1969^{97}$, persegue a formulação de uma definição de individuação de eventos, recorrendo a relações causais entre eventos, com o intuito de apresentar um teste que garanta a admissibilidade de uma ontologia de eventos para a linguagem ordinária. Quine, mais de uma década mais tarde, publica um artigo, intitulado "Events and Reification" (1985), no qual faz objeções à solução de Davidson para

\footnotetext{
${ }^{97}$ Um primeiro espoço deste artigo foi apresententado, em 1967, em um colóqui na University of California. Ele foi publicado dois anos depois no livro Essays in Honor of Carl G. Hempel, editado por Nicholas D. Reidel Publishing Company, p. 216-34. O texto depois é reeditado em Essays on Actions and Events.
} 
o problema da identidade de eventos. Nas próximas subseções focaremos esse debate estimulante entre os dois filósofos.

\subsubsection{O critério de Davidson e a objeção de Quine.}

O critério geral de identidade em tese deve dar condições necessárias e suficientes para que entidades de um dado tipo sejam individuadas. No caso de eventos, uma definição que apresente a seguinte forma:

Se $\mathrm{x}$ and $\mathrm{y}$ são eventos, então $\mathrm{x}=\mathrm{y}$ se e somente...

Parece que temos enunciados de identidade para uma série de entidades. Por exemplo, objetos materiais são idênticos se e somente se eles ocupam o mesmo lugar ao mesmo tempo (coextensividade espaço-temporal), duas classes são idênticas se e somente se possuem os mesmos membros, dois lugares são idênticos se e somente se são justapostos pelos mesmos objetos, etc. Mas quanto aos processos de modificação de objetos (i.e., eventos), são eles suscetíveis de reificação via um critério de identidade que garanta o estabelecimento de condições necessárias e suficientes para se afirmar e negar identidade? Ou esse empreendimento estaria de antemão condenado a definições circulares? Somos encorajados a postular eventos em função, em termos wittgensteinianos, de confusões gramaticais, i.e., das extrapolações de regras gramaticais de um domínio da língua para um outro domínio? Teriam sido as regras de uso do nosso aparato de reificação, originariamente empregadas para denotar e descrever entidades físicas, transferidas para o domínio do discurso sobre mudança? Motivado por algumas dessas indagações, Davidson empreende uma tentativa de formular um critério preciso de identidade para eventos, de maneira a conseguir que eventos, por assim dizer, sobrevivam ao teste de "admissibilidade ontológica" requerido por Quine, erigindo, com isso, uma base de fundamentação lógica para uma ontologia que os inclua. Vejamos, na próxima seção, as etapas dessa argumentação, para, logo em seguida, expor as críticas de Quine à definição formulada por Davidson e as respostas deste às objeções de Quine. Em „The individuation

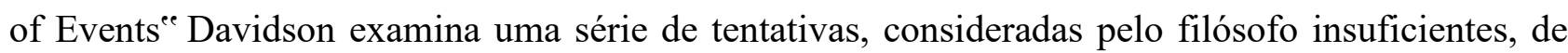
individuação de eventos, antes de apresentar a que ele espera que seja uma resposta satisfatória. Em algumas das tentativas que Davidson descarta apresentando contraexemplos que as colocam em xeque, são mobilizadas definições, a princípio, bem-sucedidas, de individuação de outros tipos de entidades, como objetos materiais, lugares, tempo, etc.

Uma tentativa é a de caracterizar eventos idênticos com base na noção de lugar. Eventos seriam idênticos quando ocupam o mesmo lugar. Mas qual é, por assim dizer, o lugar privilegiado 
de um evento? Poderíamos, a princípio, tentar localizar espacialmente um evento determinando, por exemplo, a substância que ele muda, i.e., identificar o evento com o lugar em que ele acontece (evento = lugar). Mas se evento se caracteriza como modificação de substâncias, então o lugar de um evento seria a substancia que ele altera. Mas essa estratégia coloca sérios problemas para a identificação de evento com o lugar da sua ocorrência. Por exemplo, qual a localização de um corte no braço de Pedro? Somente no local onde ocorre o corte, ou em todo o braço, ou ainda em todo o corpo de Pedro? Nota Davidson,

Se uma substância é parte de outra, uma mudança na primeira é uma mudança na segunda. Toda substância é parte do universo: logo, toda mudança é uma mudança no universo. Do que parece se seguir que eventos simultâneos têm a mesma localização (Davidson 2011 [1969]: 175).

Substâncias são inclusivas, no sentido que o braço de Pedro é parte de Pedro. E, dado que as substâncias são partes umas das outras, então o braço de Pedro é parte do corpo de Pedro, e Pedro é parte do local onde ele se encontra no momento em que ocorre o corte. E mais, sendo todas as substâncias do universo partes do universo, este pode ser caracterizado como uma espécie de substância universal. Assim, se identifico o corte no braço de Pedro com o lugar ocupado pelo braço, sou levado a concluir que um corte no braço de Pedro é uma mudança no seu braço, que, por inclusão, é uma mudança em Pedro e também uma mudança no lugar em que Pedro se encontrava quando ocorre o corte, que, por sua vez, é uma mudança no universo, já que toda mudança é uma mudança no universo. Com isso, somos necessariamente levados à conclusão - implicada pela conjunção de três premissas - no mínimo de difícl sustentação: (i) se a localização do evento é todo o espaço ocupado pela substância, (ii) todo evento é uma mudança no universo e (iii) todos os eventos simultâneos têm a mesma localização, então (iv) todos os eventos simultâneos são um e o mesmo evento, i.e, são idênticos.

Mas e se sustentarmos que a localização de um evento não é todo o espaço ocupado pela substância que ele modifica, mas “a localização da menor parte da substância cuja mudança é idêntica ao evento" (Davidson 2011 [1969]: 176)? Um risco num quadro de escrever é somente uma mudança na porção do quadro em que o risco é realizado? E quanto a eventos mentais, faz sentido localizar numa porção da minha cabeça um evento de recordar a festa em que estive ontem? Tomemos eventos metais. Suponha que identifiquemos eventos mentais com a pessoa que os têm, i.e., que o lugar de um evento mental é a pessoa. Nesse caso, o problema das partes ressurge, sem que nem precisemos recorrer ao universo. Pois, sendo eventos mentais identificados com a substância que mudam, no caso as pessoas, dois eventos simultâneos em uma pessoa, como sentir 
saudade e medo, teriam que ser considerados como idênticos. Conclusão também de difícil adesão. 98

Se a determinação de eventos em termos meramente espaciais se mostrou insustentável, a conjunção de tempo e espaço melhoraria a nossa situação? Ou seja, é necessário e suficiente que eventos idênticos ocupem exatamente ao mesmo tempo o mesmo espaço? Trata-se neste caso de investigar se um evento pode ser identificado com uma porção do espaço-tempo. Davidson também levanta dúvidas quanto a essa estratégica e ilustra sua objeção com um caso interessantíssimo: "se uma bola de metal se torna mais quente durante um minuto, e durante o mesmo minuto tem uma rotação de 35 graus, devemos dizer que ambos são o mesmo evento?” (Davidson 2011 [1969]:178). O esquentar da bola e a sua rotação ocorrem ao mesmo tempo e no mesmo espaço, e ainda assim não estamos certos se são um e o mesmo evento.

Após descartar ensaios de formulação de critérios de identidade entre eventos via referência a porções do espaço-tempo, Davidson recorre a relações causais entre eventos para fundamentar a sua proposta. Lembremos que Davidson - em grande medida em função de descrevermos recorrentemente ações e eventos em termos das suas relações de causa e efeito - concebe relações causais como relações entre eventos e atribui a uma sentença como „A explosão causou a queda da ponte $^{e c}$ a forma lógica que revela uma relação entre dois eventos descritos pelas descrições definidas „,a explosão e e, a queda da ponte ${ }^{e e}$. A proposta é de que eventos são idênticos se, e somente se, eles possuem as mesmas causas e efeitos. A definição é a seguinte (onde $e, e$ ', assim como $\mathbf{z}$, são variáveis para eventos):

$$
\text { 24. } \left.\left.e=e^{\prime} \leftrightarrow \forall z \text { ( } z \text { causou } e \leftrightarrow z \text { causou } e^{\prime}\right) \& \forall z \text { ( } e \text { causou } z \leftrightarrow e^{\prime} \text { causou } z\right)
$$

Essa proposta poderia garantir a individuação porque eventos pareceriam ter "uma posição única no quadro das relações causais" (Davidson [1969] 2011: 179). No sentido de que, se identifico o(s) eventos(s) a(s) causa(s) de um evento e o(s) evento(s) efeito(s) deste evento, determino a posição de um evento num encadeamento de determinações causais. Na perspectiva de Davidson, se a sua definição estiver correta, "é fácil apreciar porque tão frequentemente identificamos ou descrevemos eventos em termos de suas causas e efeitos" (ibidem 2011[1969]: 179). Isso se deve principalmente ao fato de que causas e efeitos "são características que garantem a individuação de eventos, no sentido não somente de distingui-los, mas também de identificá-los" (ibidem 2011[1969]: 179).

\footnotetext{
${ }^{98}$ Um outro problema levantado por Davidson é a respeito de eventos matemáticos. Pergunta o filósofo: faz sentido se perguntar onde o cálculo infinitesimal foi inventado? Ou seja, eventos matemáticos são suscetíveis de identificação espacial? E mais, faz sentido localizar um evento matemático na pessoa que o formulou? Se seguirmos nesse raciocínio, certamente terminaremos identificando eventos matemáticos distintos, o que seria um absurdo.
} 
Davidson reconhece que "uma coisa é um critério ser correto, e outra coisa é ele ser útil" (ibidem 2011[1969]: 179). As imprecisões dos termos de nossa linguagem usados para se referir e delimitar entidades no mundo não são sanadas por meio de um critério geral correto. Nem é esse o propósito de se formular uma definição geral para se individuar um tipo de entidade. A imprecisão é própria da nossa maneira de falar sobre o mundo, e a procura por uma definição que individue determinada entidade está vinculada à tentativa de dar um estatuto ontológico a entidades que nossa linguagem, a princípio, parece postular como existentes. Um critério de identidade consiste, então, num conceito geral que, se correto, garante tão somente a existência de um tipo de entidade em uma dada ontologia. Mas Davidson argumenta que, mesmo que seu critério de individuação e o critério em termos espaço-temporais estivessem ambos corretos, em casos específicos, a sua proposta, além de correta, revela-se mais útil para se sustentar a identidade entre dois eventos específicos, do que qualquer critério que apele à coextensividade espaço-temporal. Um caso hipotético fornecido é da possível identidade entre uma dor que alguém sente em uma situação e um evento fisiológico complexo. Suponha que a dor seja um incômodo no ombro. Em termos espaço-temporais, é realmente difícil, senão impossível, identificar a dor localizada no ombro por um período de tempo, com o conjunto de informações enviadas pelos músculos ao sistema nervoso central e de informações que retornam, etc. A melhor evidência que teríamos para se sustentar um identidade entre a dor e o evento físiológico, são causas e efeitos que entendemos serem os mesmos tanto da dor quanto da mudança fisiológica. ${ }^{99}$

No artigo "Events and Reification" (1985) Quine, todavia, levanta uma robusta objeção ao critério de individuação de Davidson. Nele procura-se examinar as implicações da teoria de eventos para a lógica, linguagem e ontologia, de forma a "considerar quais lições podem ser tiradas delas acerca da natureza da reificação" (Quine 2008 [1985]: 129). Quine constata que o critério de Davidson é uma definição circular, pois ele procura individuar eventos quantificando sobre eventos eles mesmos. Procedimento que se configuraria como um caso de definição impredicativa, i.e., uma definição de algo por apelo a uma totalidade que inclui ou depende da coisa a ser definida, caracterizando-se, por essa razão, como uma definição circular. Em termos simples, uma definição que inclui aquilo que é para ser definido. Mas não haveria a priori nada de errado ou danoso em empreender definições desse tipo ${ }^{100}$, como alguns matemáticos e filósofos costumam considerar. $\mathrm{O}$

\footnotetext{
${ }^{99}$ Mas mesmo em casos como de uma dor física, a identificação da dor com um evento fisiológico me parece bastante problemática e obscura, não sendo fácil de ser mobilizada como testemunha em favor da proposta de Davidson. Não poderíamos, em vez de identificar uma dor específica com um evento fisiológico complexo, descrever este próprio evento fisiológico como causa da dor, ou ao menos como causa parcial da dor? E mesmo que tentemos identificar os dois eventos, é possível que exista uma classe de efeitos e causas de ambos os eventos, sem que exista uma classe de apenas um evento que seja, por sua vez, causa ou efeito da dor, mas não da mudança físiológica, ou vice-versa?

${ }^{100}$ Poincaré e Russell se debruçaram sobre a circularidade das definições impredicativas em matemática.
} 
problema emerge, na sua visão, quando se pretende individuar objetos de forma impredicativa. E é isso que diferencia uma definição predicativa de uma impredicativa no caso de um critério de identidade para objetos/entidades: a possibilidade de individuação via definição. Em (24), a referência a eventos ocorre também no lado direito do bicondicional, ou seja, no definiens. Neste o quantificador universal quantifica sobre uma variável $\mathbf{z}$ para eventos. De maneira que, na própria definição, acaba-se por pressupor como já definido o que se espera justamente definir. Tome-se a definição de identidade de classes, a saber, a que diz serem duas classes idênticas quando elas possuem os mesmos membros. Ela individua classes "apenas na proporção em que seus membros são individuados" (Quine 2008 [1985]: 134). Do mesmo modo, a definição (24) somente valeria como critério de individuação se eventos já tivessem sido individuados, o que não é o caso. Mas o paradoxo é que (24) é apresentada como um critério geral de individuação de eventos. Logo, (24) não cumpreria o papel a ela atribuído. No texto em questão Quine manterá a mesma posição já sustentada em Word and Object: que ainda o critério mais seguro de identidade entre eventos é o da coextensividade espaço-temporal. Eventos então também seriam concebidos como porções do espaço-tempo

Objetos físicos, concebidos então [...] no espaço-tempo, não devem ser distinguidos de eventos, ou, no sentido concreto do termo, processos. Cada um compreende simplesmente o conteúdo, por mais heterogêneo, de alguma porção do espaço-tempo, por mais descontínuo e rearranjado (Quine 1960: 171).

Mas não é justamente ao apelo ao critério espaço-temporal para se individuar eventos que Davidson levanta a objeção bastante forte do exemplo da bola de metal? Como já mencionado, suponha uma bola de metal que no curso de um minuto aumenta a sua temperatura e, durante exatamente o mesmo minuto, sofre uma rotação de 35 graus. O esquentar da bola e a rotação, que ocorrem no mesmo lugar ao mesmo tempo, são o mesmo evento? Parece que somos tentados a considerar eventos distintos. E, se de fato são distintos, esse exemplo é um forte candidato para bloquear a alternativa do critério espaço-temporal. Um proponente da concepção de que eventos possam ser caracterizados como porções do espaço-tempo precisaria fornecer uma solução convincente para casos como da bola de metal. Contudo, Quine não é dissuadido pelo exemplo de Davidson, e não vê problema em identificar o esquentar da bola com a sua rotação:

Dado que o aquecer da bola esquenta as suas adjacências, eu admito que a sua rotação, nesse exemplo, esquenta também as adjacências. Estou contente do mesmo modo em concluir que o mascar chicletes de Sebastian o fez atravessar Bolonha, se ele coincidir [espaço-temporalmente] com seu caminhar (Quine 2011 [1985]: 135). 
Para todos os eventos que tomam a mesma porção do espaço-tempo não há razão para não considerá-los idênticos. Se mastigo algo somente enquanto atravesso o meu quarto, tanto o mastigar quanto o atravessar ocorrem na mesma porção do espaço-tempo, e, por isso, são idênticos. O mesmo com o caso da bola. A distinção entre esses eventos, em contrapartida, emerge de forma bastante nítida quando observados sob a perspectiva dos seus feitos, pois o esquentar da bola pode ter efeitos diferentes dos provocados por sua rotação: por exemplo, a rotação da bola pode ser a causa da queda de um cisco que nela estava, enquanto o seu esquentar não. O mesmo ocorre com o mastigar. Posso morder minha língua como resultado do mastigar, e não do caminhar. Mas, como aqui mobilizaríamos relações de causa e efeito, fazemos a diferenciação tendo por base o critério geral (22), que se revelou falho, em função da sua circularidade como definição. Entretanto, Quine observa que o caso da bola de metal levanta um problema ainda maior. Suponha que a rotação da bola seja rápida e o seu esquentar devagar. Podemos dizer, por causa disso, que esse evento é rápido e devagar? Quine conclui que, em função desse problema, "talvez devemos recuar [...] para uma versão mais complexa, construindo um evento como um par de um objeto físico e um conjunto distintivo de algum tipo" (ibidem 2011[1985]: 136). Mas não se aventura em formular essa nova versão e permanece tratando eventos como porções do espaço-tempo. Ao menos neste artigo, Quine varre para debaixo do tapete o problema de se atribuir predicados contrários por meio da sua conjunção a um mesmo evento, e não apresenta uma solução. A conclusão de Quine é que a vagueza que entrevemos assim que tentamos impor uma precisão maior na demarcação de objetos físicos e eventos está vinculada muito mais ao uso dos termos de nossa linguagem e aos propósitos com os quais usamos esses termos do que uma imperfeição do critério de coextensividade espaçotemporal. Por essa razão, e tendo em perspectiva o fracasso da estratégia davidsoniana, o critério espaço-temporal se configura, na leitura de Quine, como a melhor alternativa, aplicável tanto a objetos quanto a eventos. Um único critério abarcando duas entidades essencialmente vinculadas: objetos e modificações em objetos. Enquanto porções do espaço-tempo, projeções de uma mesma matriz comum, objetos físicos e eventos emergiriam como entidades interdependentes: não há objetos físicos que não sofrem mudanças, assim como não há mudanças sem que sejam mudanças em objetos. Mudança pressupõe permanência, que, por usa vez, pressupõe a mudança.

Em um texto em resposta às objeções de Quine, intitulado "Reply to Quine on Events"101, Davidson acata as críticas recebidas e abandona a definição de identidade de eventos proposta no artigo de 1969, reconhecendo a sua insuficiência e circularidade. Ainda no artigo de 1969 Davidson já especula que a identidade entre a rotação da esfera com o seu esquentar poderia talvez ser

\footnotetext{
${ }^{101} \mathrm{O}$ texto aparece como apêndice B da última seção de artigos no livro Assays on Actions and Events.
} 
defendida com a ajuda de uma teoria científica. Talvez seria viável ensaiar uma identificação entre os dois eventos, por exemplo, envolvendo as partículas constituintes da bola. "Poderia ser mantido que o esquentar da bola durante $m$ é idêntico à soma dos movimentos das partículas que constituem a bola durante $m$; e o mesmo com a rotação" (Davidson 2011 [1969]: 178-179). Mas tal estratégia acrescenta novas dificuldades. Temos de pressupor uma série de teorias científicas, e entidades postuladas por essas teorias. O que impõe problemas ainda maiores; problemas referentes, por exemplo, ao deslocamento e posição de partículas subatômicas. Além disso, o paradoxo a que fomos levados ao identificar um evento com o lugar da substância não reapareceria aqui também? Se as partículas da bola forem partes (inclusivas) da bola, e os movimentos das partículas eventos que modificam essas mesmas partículas, os quais, por sua vez, são identificados com os lugares nos quais as partículas se encontram em um dado instante, não somos conduzidos à conclusão de que todos os eventos que ocorrem simultaneamente na bola são identificados com o lugar que a bola ocupa, e que, portanto, todos os eventos que modificam concomitantemente a esfera seriam um e o mesmo evento?

No artigo mencionado acima Davidson descarta a solução com apelo a teorias científicas, e conclui justamente que “o critério de Quine é mais claro e melhor, pois não precisa de uma teoria científica como apoio" (Davidson 2011: 310). Davidson reconhece a circularidade da sua definição e acata a solução quineana, ainda que muito mais por ausência de um critério que substitua sua proposta de 1969. Na resposta a Quine, Davidson, em nenhum momento, contudo, menciona o problema colocado pela identificação da rotação da esfera com o seu esquentar, se concebermos que a rotação pode ser rápida e o esquentar lento. Isto é, se num cenário como esse podemos ou não dizer que o evento é simultaneamente rápido e lento.

Mas embora Davidson, por um lado, acabe aceitando o critério de coextensividade espaçotemporal para eventos, por outro, ele levanta um novo problema, talvez mais desafiador ainda: casos limites em que parece que tanto posso conceber uma entidade como objeto físico quanto como evento. Casos que, crê Davidson, questionam a distinção que ele atribui a Quine: de que pode ser que eventos ocorram uma vez em um lugar, enquanto objetos físicos ocupem diferentes lugares em diferentes tempos ${ }^{102}$. Se, por exemplo, "uma onda cruza um oceano, isso é um evento do ponto de vista, por assim dizer, do oceano. Mas também a onda é um objeto, no seu próprio direito, mantendo uma forma geral enquanto rapidamente mudando de águas" (Davidson 2011: 310). Uma

\footnotetext{
102 Davidson argumenta, na resposta de 1985, que o fato de Quine identificar eventos, assim como objetos, com porções do espaço-tempo, não significa que o filosofo colapsa objetos físicos com eventos, no sentido de não haver meios de diferencia-los. Pois, segundo Davidson, Quine concebe que eventos e objetos podem estar relacionados a localizações no espaço-tempo de maneiras distintas, podendo ser que eventos ocorram em um tempo em um lugar, enquanto objetos ocupam lugares distintos em momentos distintos. Não encontramos essa distinção formulada no artigo Events and Reification, tampouco Davidson se refere ao texto onde essa posição estaria exposta.
} 
montanha pode ser vista como objeto, como comumente no discurso ordinário, ou como apenas um evento da história geológica da Terra. A distinção quineana (ou melhor, atribuída por Davidson a Quine) pode inclusive ser questionada sem exemplos que colocam dificuldades para se decidir entre eventos e objetos. Não seria uma guerra um evento que pode parar por um tempo e ser reiniciado em outro local mais tarde, e que ainda assim continuamos considerando a mesma guerra? Nesse sentido, áreas do espaço-tempo, por si, em alguns casos não são suficientes para distinguir entre coisas que permanecem as mesmas na mudança (objetos físicos) e mudanças em coisas (eventos). Os exemplos da montanha e da onda se configurariam, parece-me, como casos em que a vagueza é entre conceber como objeto físico ou conceber como evento. Assim, tendo em perspectiva esses casos, podemos cogitar que uma onda e uma montanha são entidades indeterminadas? Se eles são, continuamos insistindo em fazer distinções em situações distintas e com propósitos distintos. Então quem ou o que faz a distinção? Quem ou que não permite essa indiferença? "Nossos predicados, nossa gramática básica, nossos modos de escolher” (idem) fazem essas distinções. “A gramática não permite confusões" (idem), conclui Davidson. Por fim, o que temos então é a nossa gramática, nossos modos de predicar, i.e., nossa linguagem, talvez menos vaga do que imaginávamos? Só nos resta, então, procurarmos unicamente nela a metafísica implícita, as entidades que, se não existissem, teríamos de acreditar que sim, pois nossa linguagem não nos deixaria escolha?

\subsubsection{Impasse não resolvido?}

O que permanece como mais desafiador para a pesquisa filosófica sobre eventos são os casos borderlines de indeterminação entre objetos e eventos. Se uma montanha pode ser designada tanto como objeto quanto como evento, devemos fazer as seguintes perguntas: em última instância, todo objeto físico pode ser concebido como um evento e todo evento como um objeto físico? E se assim o for, ou melhor, se assumimos essa postura, quais são as suas implicações? Se o que determina que uma entidade seja vista como um objeto ou um evento são nossos "ways of sorting", nossas descrições, então o que devemos perseguir, caso rejeitarmos a solução espaço-temporal, é um critério geral de individuação que cubra entidades vistas como objetos materiais ou eventos? Um critério geral independentemente das distinções que nosso modo comum de falar sobre o mundo faz, i.e., independentemente da nossa habilidade cognitiva de adotar distintas perspectivas sobre uma mesma situação perceptiva? Se a definição espaço-temporal for a mais vantajosa, termina-se quantificando sobre porções do espaço-tempo e, de acordo com os predicados aplicados a essas porções em circunstâncias determinadas, acabamos vendo essas porções como processos ou objetos. Mas, então, no limite, nenhuma entidade espaço-temporal é em si mesma um objeto físico ou evento. Estaríamos dispostos a sustentar esse raciocínio? Adotá-lo implica que todos os objetos 
físicos sofrem mudanças enquanto são também mudanças, e que, por seu turno, mudanças podem também ser objetos que sofrem mudanças. Somos conduzidos, portanto, a um dilema insolúvel, um ponto de indecisão, que não é senão o resultado da implosão da distinção ontológica entre substância e processo. Mas se, como último recurso, decidimos só pela mudança, a mudança muda o quê? Mas também não queremos um universo estático, constituído apenas de substâncias.

Contudo, ainda que o problema ontológico permaneca, nossa linguagem nos força recorrentemente a conceber o conteúdo de uma situação perceptiva como objeto ou evento. No labirinto da nossa linguagem convivemos com esse dilema, uma vez que só aparece como um dilema para quem tenta olhar para ele como que de fora do labirinto. Pode ser que um caminho, caso não queiramos a todo custo nos comprometer com o colapso ontológico entre substância e evento, é continuar procurando por um critério geral de identidade restrito somente a eventos. Mas existe tal critério? Podemos ainda sustentar uma ontologia de eventos como particulares sem implodir a possibilidade de distinguir se estamos diante de um objeto ou evento? A dificuldade de conceber evento como uma entidade distinta, um particular oposto aos objetos, com seu próprio critério rigoroso de individuação - considerando os casos de fronteiras borradas - ajudou a balançar a própria noção de objetos como particulares com um critério independente. Do ponto de vista de um metafísico, não dizemos muito afirmando que nossa linguagem faz a distinção. Casos em que não podemos distinguir objetos de eventos podem refletir uma indeterminação ontológica para a qual parece não haver uma solução semântica. Em contrapartida, para o semanticista que não quer manter seu empreendimento sob o fardo de uma austeridade ontológica acarretada pelo critério de admissibilidade mantido por Quine, há um argumento convincente em favor de um universo mais populoso: comumente damos um estatuto ontológico positivo a entidades para as quais ainda nos falta um critério de identidade claro. Confiamos, presumivelmente, que existem pessoas em nosso universo embora pareça que ainda não temos formulado um critério claro de identidade pessoal. E a falta de uma definição clara não é suficiente, por razões mais do que suficientes, para convidar as pessoas a, ao menos temporariamente, até que encontremos um bom critério, se retirar da nossa ontologia, como assinalou Haack (1978). Além disso, em termos de uma teoria semântica para as línguas naturais, um modo prático de evitar essa austeridade tem sido a postulação de entidades à revelia de qualquer empreendimento filosófico a procura de um critério de individuação. Na maioria das vezes a balança tendeu para a postura de relaxar o rigor do critério de admissibilidade ontológica, e permitiu a introdução de novas entidades, mesmo sob o risco de não encontrar um critério de identidade para elas, sempre que tal tolerância ajuda a expandir o escopo de uma teoria semântica, estendendo, portanto, o horizonte de nossas previsões, como ocorreu com a introdução de eventos. E ao cabo esta passa a ser a posição de Davidson: submeter a adesão ao critério de 
admissibilidade ontológica às vantagens da ampliação do horizonte explicativo de uma teoria. Com eventos como argumentos quantificados de verbos, Davidson forneceu um método composicional e recursivo de tratar a modificação adverbial. Desse modo, para o projeto de uma semântica de condições de verdade para as línguas naturais, manter eventos é mais promissor, do ponto de vista empírico, do que uma restrição ontológica que o critério de Quine impõe de partida. Em virtude da dificuldade geral de formular um critério preciso de individuação de entidades, a postulação de eventos tem, portanto, um grande apelo instrumental: a solução de Davidson descreve a validade de algumas inferências como um resultado do modo que sentenças são construídas a partir de suas partes constitutivas. A capacidade de mostrar relações inferenciais como composicionalmente estruturadas é uma condição necessária para uma semântica que pretende ser uma teoria formal da linguagem ordinária, sendo, nesse sentido, um fator central para avaliar sua adequação.

Eventos como nós na rede de ligações inferenciais entre sentenças, roubando aqui uma metáfora quineana, expande o alcance explanatório de uma teoria composicional. Se tivermos um critério de individuação de eventos, muito melhor! Mas, se não tivermos, não precisamos começar do início novamente. Continuemos construindo nossa semântica com as ferramentas que forjam o caminho. O critério de admissibilidade ontológica - uma vez afrouxado - deve funcionar mais como um princípio regulador que sugere prudência na postulação de novas entidades na busca por explicar inferências intuitivamente percebidas em uma linguagem sob escrutínio, e não um postulado suficiente para bloquear a introdução de uma entidade em uma teoria semântica, visto que o aspecto mais perigoso de uma teoria do significado não é de longe as entidades que ela assume, mas o risco de ser uma teoria que se configure como impossível de ser aprendida por um ser finito, como no caso de teorias com um vocabulário básico infinito. Seguir rigorosamente a prescrição de que não se deve postular uma entidade sem que se esteja em posse de uma definição que a individue, pode minar o otimismo de forjar uma teoria formal do significado para fragmentos importantes das línguas naturais, como as sentenças de ação. E, dado os resultados alcançados até agora, me parece que seria inconsequente abandonar este otimismo.

\section{De volta ao Paradoxo do Mentiroso.}

Como vimos na seção 3 do capítulo II, paradoxos semânticos - especialmente o do mentiroso parecem apresentar dificuldades incontornáveis para o emprego de uma teoria da verdade de tipo tarskiana na construção de uma semântica para as línguas naturais ${ }^{103}$. Recordem que fonte da antinomia do mentiroso nas línguas naturais decorreria do fato de elas possuirem recursos

\footnotetext{
${ }^{103}$ Ver o capítulo II para uma exposição detalhada de como o paradoxo pode ser construído nas línguas naturais.
} 
expressivos para falar das propriedades semânticas das suas próprias expressões. Isso porque uma língua natural possui (i) meios de se referir aos próprios objetos linguísticos que a constituem, incluindo suas sentenças, (ii) assim como contêm seu próprio predicado de verdade e outros termos semânticos. Pressupondo que as línguas naturais estão em conformidade com os princípios lógicos fundamentais, o diagnostico é que justamente a conjunção das propriedades (i) e (ii) permite engendrar a antinomia do mentiroso, nos casos em que se tenta fornecer sentenças-T para sentenças que já contenham seu próprio predicado de verdade. A consequência disso, para Tarki, é que uma teoria da verdade da qual se derivam contradições formais não pode ser verdadeira. Ele conclui, então, que uma definição semântica de verdade não pode ser consistentemente fornecida para linguagens objetos que possuem seus próprios predicados de verdade. Com base nisso, a estratégia sugerida é de definir verdade somente para linguagens que não apresentam entre suas expressões termos predicativos como , $\mathrm{x}$ é verdadeira ${ }^{e e} \mathrm{e}, \mathrm{x}$ é falsa

A literatura sobre paradoxos semânticos na linguagem coloquial, em particular a antinomia do mentiroso, é vasta e pouco consensual. O objetivo aqui não é de percorrer toda essa literatura. No que se segue, o propósito é de focar duas questões. Em primeiro lugar, examinar o que Davidson sugere como resposta aos possíveis desafios impostos pelo paradoxo do mentiroso. Para ele a derivação do paradoxo do mentiroso se revela um problema localizado, ou seja, circunscrito apenas às sentenças com predicados de verdade, e que ele não precisa afetar a viabilidade de uma teoria da verdade como veículo de uma teoria composicional do significado para fragmentos de sentenças de uma língua natural nas quais não ocorrem tais predicados. Em segundo lugar, entretanto, pretendo destacar algumas consequências oriundas fato de que tal posição, se correta, condena uma teoria interpretativa da verdade para uma língua natural à parcialidade.

As reflexões de Davidson sobre o tópico são mais sugestões do que posições definidoras. As passagens dos textos em que ele aborda o problema são concisas, e não recebem o destaque que comumente se esperaria, dada a importância que se atribui aos paradoxos semânticos como evidências robustas contra o projeto que o próprio Davidson persegue. Essa pouca atenção à questão é sintomática da sua postura com respeito a ela. Visto que Davidson não vê que, ainda que fragmentos das linguas naturais possam ser infectados pela antinomia do mentiroso, isto seja razão suficiente para inviabilizar seu projeto, antes de nos determos a tal problema, sugere ele, mais imperativo é demonstrar que uma teoria interpretativa da verdade possa ser formulada e modificada de modo a demonstrar que ela fornece um tratamento adequado de fenômenos linguísticos, digamos, mais elementares das linguas naturais que escapam às linguagens formalizadas: o fato das condições de verdade das sentenças serem relativizadas a falante e tempo, a diversidade da estrutura quantificacional, a relação entre as sentenças de ação e os advérbios, contextos opacos, etc. Se 
Davidson não acreditasse que o problema do paradoxo, se existente, é um fenômeno localizado, e que, embora possa se revelar imune a soluções, não coloca em risco todo o empreendimento, parece-me que seu esforço de enfrentar antes fenômenos como os exibidos nas seções precedentes não teria razão de adquirir destacada prioridade. Davidson não acredita que o exercício de propor soluções para os fenômenos mencionados esteja em todo momento sob o risco de se revelar vão, se ao cabo uma solução convincente também não for construída para o paradoxo.

Uma passagem textual bem ilustradora da sugestão de Davidson de que o padadoxo do mentiroso é um problema local que não coloca em risco a teoria aparece em "In Defense of Convention-T". Diz Davidson:

\begin{abstract}
Uma vez que tudo isso é permitido [recursos para se referira às proprias sentenças e predicar verdade delas] na linguagem, antinomias semânticas são geradas. A ideia de uma teoria da verdade para uma língua natural em uma língua natural é, portanto, inatingível se nos restringirmos aos métodos de Tarski. A questão que surge então é: como ceder o menos possível; e aqui teorias permitidas pela Convenção-T parecem, em aspectos importantes, ótimas. [...] É somente o predicado de verdade (e o predicado de satisfação) que não podem estar na linguagem objeto (Davidson 1990 [1973]: 72).
\end{abstract}

A ideia é de que as omissões dos termos semânticos e do aparato referencial em sentenças que originam paradoxos do tipo do mentiroso não afetam o resto da linguagem objeto e não comprometem a formulação para ela de uma teoria que obedece à Convenção-T. $\mathrm{O}$ fato de se "exorcizar" da linguagem objeto seu vocabulário semântico não interferiria no significado dos termos não semânticos. Se essa postura estiver correta, e formos capazes de construir uma teoria interpretativa da verdade para o restante da linguagem, podemos iluminar para todas as sentenças "não-semânticas", como que seu significado é uma função do significado de suas partes e do seu modo de combinação.

O percurso é basicamente extrair da língua natural sob investigação os recursos disponíveis para se falar na própria língua das propriedades semânticas de suas expressões. O resultado é uma linguagem menos rica no seu poder de expressão, mas ainda suficientemente vasta e inalterada nos seus recursos expressivos que não envolvem predicar verdade das suas próprias sentenças. $\mathrm{O}$ argumento subjacente a essa estratégia é basicamente o seguinte: ainda que o intento de fornecer uma teoria do significado via uma teoria da verdade para toda uma língua jamais seja cumprido, os amplos fragmentos que podem ser incorporados e descritos pela teoria demonstrariam o seu significativo alcance empírico e a precipitação injustificada do peso dado aos paradoxos semânticos. Em outras palavras, mesmo sendo as línguas naturais sujeitas ao paradoxo do mentiroso, não precisamos de imediato concluir que tal fenômeno seja suficiente como obstáculo incontornável que condenaria ao fracasso o empreendimento de se construir uma teoria semântica 
de tipo tarskiana para o restante de uma língua natural. Aqui é importante sublinhar que tal posição parece incompatível com a adoção de um holismo semântico radical; pois, se a exclusão de um termo ou a modificação do seu significado necesssariamente resultar na alteração do significado de todos os outros termos da linguagem, a defesa do paradoxo do mentiroso apenas como um problema localizado, que não compromete uma teoria do significado para o restante de uma língua natural, se torna insustentável.

Ainda que a sugestão de Davidson esteja correta, e creio que esteja, o fato de uma teoria interpretativa da verdade ser consistentemente aplicável somente a fragmentos das línguas naturais que não contêm predicados de verdade e outros termos semânticos (de maneira que na teoria não seja preciso construir axiomas para os predicados semânticos que ocorrem nas línguas naturais), acarreta a consequência nada desprezível de que uma tal teoria está de antemão fadada a cobrir apenas fragmentos da linguagem coloquial, e, portanto, necessariamente a ser uma teoria parcial, por maior que seja o escopo dos fenômenos linguísticos passíveis de serem tratados por ela. E não me parece nada desprezível ou de valor menor as consequências de uma estratégia que omite uma explicação das sentenças com termos semânticos. Isso porque a capacidade de descrever as características semânticas de suas próprias expressões e de se referir a elas não é um procedimento, em língua natural, meramente residual, esporádico. Pelo contrário. No jogo de interpretar um falante e ser interpretado, falar dos próprios elementos linguísticos enunciados, tê-los como objetos de referência, é mais recorrente do que nos damos conta. Tais recursos parecem cumprir um papel considerável na interpretação linguística. Mecanismos de citação, discursos direto e indireto, e atribuição de verdade a sentenças, etc., permeiam as trocas linguísticas e operam na determinação das interpretações. À luz dessas considerações, muito do que é recorrente e determinante no uso cotidiano da linguagem fica à margem de receber um tratamento em uma semântica composicional como a proposta. Por conseguinte, muito do que seria interessante e enriquecedor para se perseguir em uma semântica para a linguagem coloquial, a saber, conseguir explicar essa capacidade de autoreferência, de criar nomes de nomes, nomes de sentenças, nomes de sentenças no interior de sentenças, resulta, de antemão, fora do escopo explicativo da teoria. Sem uma solução para esses fenômenos comuns no nosso uso da linguagem, o que temos é uma teoria que não somente não cumpre a sua ambição inicial, como também, em virtude da sua parcialidade e de onde esta incide, resulta significativamente empobrecida, uma vez que a linguagem que explica é consideravelmente mais empoprecida do que a que qualquer falante conhece e usa.

\section{Ausência de estruturas exatas nas línguas naturais: um problema de fato?}


Outra dificuldade para a qual Tarski chama a atenção diz respeito à subespecificação sintática das expressões de uma língua natural. A ideia é de que as línguas naturais não possuem estruturas sintáticas exatas, com base nas quais se consiga determinar a categoria dos termos que formam seu vocabulário, assim como individuar quais expressões são sentenças. Uma teoria recursiva para uma linguagem objeto demanda uma caracterização formal das suas expressões que garanta, na posse de uma definição precisa de sentença, gerar as condições de verdade de uma sentença a partir das condições de satisfação atribuídas às unidades subsentenciais (seu vocabulário) que a constituem. Entretanto, não é nada trivial determinar exatamente o vocabulário de uma língua natural. Recorrentemente expressões lexicais podem funcionar como sentenças e estruturas que, quando usadas, operam como sentenças, em contextos em que são mencionadas funcionam como nomes. Além disso, a indicação da gramaticalidade de construções linguísticas nas línguas naturais não é um procedimento que pode simplesmente ser determinado com critérios sintáticos. A perspectiva de transformações e desenvolvimentos históricos de uma língua, para não mencionar variações sincrônicas, indicam que palavras e construções que num dado período são consideradas gramaticais, em um período subsequente já podem não ser.

Mas os fatos acima sobre as línguas naturais seriam suficientes para tornar vão o empreedimento de desenvolver uma semântica formal para as línguas naturais? São tais fatos barreiras que inviabilizam a especificação de um vocabulário e gramática para amplos fragmentos de uma língua, de maneira que uma teoria da verdade possa ser aplicada a eles? Não creio que a resposta seja afirmativa. Como já argumentada na subseção 2.1 do presente capítulo, uma teoria da forma proposta por Davidson, e que se destina a ser empírica, hipotetiza as estruturas de uma língua, de maneira a, mediante estas categorias postuladas, predizer as condições de verdade das sentenças em uso. A regimentação de um fragmento de uma língua em nomes, quantificadores, predicados, conectivos, etc., está sempre sujeita a novas observações e suscetível de ser revista com base no comportamento das sentenças em uso. O que ocorre é a formulação de estruturas que operam na modelação e organização dos dados. Logo, seu valor empírico consiste no papel que cumprem na conformação das explicações e predições. $O$ teste de se a classificação de uma classe de expressões é adequada ocorre na observação de se as expressões assim caracterizadas, e às quais são atribuídas cláusulas de satisfação, contribuem para capturar as condições de verdade das sentenças em uso nas quais aparecem. O critério para identificar se o que foi enunciado por um falante pode ser caracterizado como uma sentença (declarativa) é a expressão poder ser tomada como verdadeira ou falsa. É tal atitude, que se dá na prática comunicativa, a bússula da sentencidade de algo enunciado. São esses sons e inscrições reais, que não carregam inscritos neles suas estruturas, os únicos materiais linguísticos observáveis. 
A teoria da verdade não é aplicada diretamente à lígua natural investigada, mas a uma versão regimentada dela. Para usar a teoria para interpretar um conjunto de sentenças é necessário mapear essas sentenças em versões regimentadas para as quais se tem interpretações. Inclusive é mediante este procedimento que uma sentença ambígua, i.e., com mais de um significado, pode ser mapeada em mais de uma estrutura, indicando, assim, que ela pode receber distintas interpretações, e, por conseguinte, distintas sentenças- $\mathrm{T}$ de acordo com as sentenças regimentadas nas quais é mapeada. O mesmo percurso ocorrendo em casos de ambiguidade lexical. Se uma palavra pode ter dois significados, como no caso de „, banco ${ }^{c e}$, a estratégia é colocar subescritos na expressão, de maneira a indicar a interpretação correspondente ao subescrito. Tarski vê todo esse empreendimento de forma bastante negativa, compreendendo-o como um recurso que impõe a estrutura de uma linguagem artificial a uma língua natural, o que se caracterizaria muito mais como uma prescrição de estruturas do que uma descrição. Não há dúvida de que opções arbitrárias são tomas algumas vezes, e que o maquinário da lógica de predicados usado na regimentação das sentenças pode não corresponder às estruturas das sentenças em uso. Mas como qualquer teoria empírica, uma semântica formal para fragmentos de uma língua natural opera com idealizações e, como dito, postula estruturas não observáveis com base em uma linguagem lógica que contribui para fornecer composicionalmente sentenças- $\mathrm{T}$.

Cabe destacar, além disso, que é um recurso usual em linguística, seja em morfologia, sintaxe ou semântica, descrever expressões das línguas naturais como possuindo propriedades e categorias que não são manifestas fonologicamente. E que postular estruturas não observáveis tem sido um procedimento em linguística teórica que - não há como negligenciar - tem permitido uma compreensão significativa das línguas naturais. Ressalvas exageradas quanto a essa prática comum em outras ciências, e pouco questionada, se adotadas por linguistas, teriam no mínimo freado, indubitavelmente, o desenvolvimento e a aplicabilidade impressionante da ciência linguística. $\mathrm{O}$ estágio de consolidação da linguística hoje, um resultado direto do conhecimento que tem produzido, parece-me a melhor resposta positiva ao ceticismo de Tarski, que, não se pode deixar de dizer, foi pronunciado num momento em que ainda estava na sua infância e, por isso, de difícil apreciação, tanto a ciência linguística quanto a contribuição determinante que métodos formais poderiam ter para o desenvolvimento da disciplina. 


\section{CAPÍTULO IV: CONTEXTOS OPACOS: PEDRA NO CAMINHO DE UMA SEMÂNTICA DAVIDSONIANA?}

Há certas frases que se iluminam pelo opaco. Manoel de Barros

\section{O problema.}

Contextos sentenciais opacos são um dos principais desafios a uma semântica de tipo davidsoniana, i.e., a uma teoria que pretende iluminar "aspectos intensionais" da linguagem objeto mediante uma metalinguagem extensional. Qualquer semântica sistemática cujo objetivo é se conformar como uma teoria do significado, mas que pretende evitar apelo direto a entidades intensionais, inevitavelmente enfrenta dificuldades para apresentar uma análise composicional e recursiva que atribua condições de verdade adequadas a sentenças com verbos que introduzem contextos opacos. São ditos opacos contextos que, a princípio, parecem violar o princípio de substitutividade, i.e., construções em que a intersubstituição de expressões coextensivas não assegura a preservação do valor de verdade das sentenças. O princípio de substitutividade pode ser expresso de duas formas:

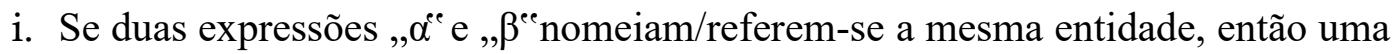
sentença não alterará o seu valor de verdade quando nela uma das expressões é substituída pela outra;

ii. Se uma sentença de identidade,$\alpha=\beta^{\text {ee }}$ é verdadeira, então as expressõesargumento „,e e , $\beta^{\text {ee }}$ são substituíveis uma pela outra (em todo lugar) salva veritate.

A primeira definição menciona diretamente a coextensividade de duas expressões, i.e., a referência a uma mesma entidade. Já a segunda faz isso de forma implícita, em termos da verdade de uma sentença de identidade. Nos critérios acima a substitutibilidade de expressões com o mesmo referente funciona tando para posições dentro de termos singulares complexos quanto para posições em sentenças. A ilustração mais evitente de tais contextos são os casos dos termos singulares na

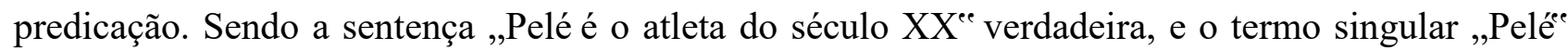
tendo o mesmo referente do termo singular „Edson Arantes do Nascimento "e então a sentença „Edson Arantes do Nascimento é o atleta do século XX 
Os contextos opacos, no entanto, parecem conflitar com os critérios (i-ii). Assumindo, a título de exemplo, que descrições definidas sejam termos singulares ${ }^{104}$, se na sentença

1. O mais velho linguista do MIT é autor de Linguística Cartesiana.

substituo a expressão descritiva „o mais velho linguista do $\mathrm{MIT}^{\mathrm{ee}}$ por „o mais famoso crítico da política externa dos EUA', o seu valor de verdade é preservado, pois ambos os termos denotam o mesmo objeto. E como o valor de verdade de uma sentença é uma função da extensão de suas unidades constitutivas, sendo (1) verdadeira, (2) também será.

2. O mais famoso crítico da política externa dos EUA é autor de Linguística Cartesiana.

Agora considere a seguinte suposição. Pedro é um amante de linguística, e sabe (acha) que não há ninguém no departamento de linguística do MIT mais velho do que Noam Chomsky. Pedro frequentemente enuncia (1). No entanto, ele não se interessa por política, e desconhece que Chomsky, além de ser o mais velho linguista do MIT, escreve livros sobre a política externa dos Estados Unidos, sendo internacionalmente reconhecido por isso . Neste contexto, se reporto

3. Pedro diz que o mais famoso crítico da política externa dos EUA é autor de Linguística Cartesiana.

enuncio uma sentença falsa, embora

4. Pedro diz que o mais velho linguista do MIT é autor de Linguística Cartesiana.

seja verdadeira. Mas por que „o mais velho linguista do MIT $^{e e}$ e „o mais famoso crítico da política externa dos EUA', ainda que termos coextensivos, quando substituídos em sentenças que reportam indiretamente o que alguém disse, podem não preservar o valor de verdade da sentença? Uma primeira pista para se enfrentar esse problema é a intuição de que em discursos indiretos parece que não estamos preocupados com as palavras que alguém usou, mas com o significado do que foi dito, com o conteúdo semântico do que é reportado.

\footnotetext{
${ }^{104}$ A controvérsia acerca da análise das descrições definidas e do seu estatuto semântico não interfere neste momento no exemplo em questão, por isso assumimos neles que descrições sejam termos singulares.
} 
Frege foi o primeiro a apontar contextos sentenciais - como (3-4) - para os quais o princípio de substitutividade, num primeiro olhar, parece não valer. Numa teoria de raiz fregeana, que toma toda expressão como tendo, por assim dizer, duas camadas de significado, i.e., além de seu referentelextensão, um termo possui sentido/intensão, o problema da substituição em construções opacas recebe um tratamento a princípio satisfatório, uma vez que a introdução da noção de sentido/intensão como parte do significado das expressões garante uma explicação na qual o princípio de substitutividade não é violado. Sob a lente de uma semântica fregeana, termos e sentenças que ocorrem como complementos de expressões verbais como ,dizer que ${ }^{e e}$,„pensar que „,acreditar que ${ }^{e e}$, etc., referem-se ao sentido que ordinariamente possuem em contextos não opacos, ao seu sentido costumeiro, no vocabulário de Frege. Em contextos opacos, a referência do termo ou sentença é, portanto, o seu sentido costumeiro. ${ }^{105}$

A resposta de Frege, bastante sagaz, para o fato de (3) e (4) não possuírem o mesmo valor de verdade é que em tais contextos sentenciais „o mais velho linguista do MIT“e e „o mais famoso dos críticos da política externa dos EUA"e se referem a diferentes sentidos, denotam distintos "modos de apresentação”. E, dado que Pedro, no contexto imaginado, desconhece que o sentido de „o mais famoso dos críticos da política externa dos EUA ${ }^{c e}$ fixa o mesmo referente que o sentido de „o mais velho linguista do $\mathrm{MIT}^{\mathrm{ee}}$, (3) pode ser falsa enquanto (4) é verdadeira. ${ }^{106}$ Além disso, sendo o sentido de uma sentença a proposição que ela veicula (em termos fregeano, pensamento), as sentenças em contextos opacos se referem à proposição que veiculam, que é uma função do sentido dos termos que a compõem. Nessa linha, em (3) e (4) temos distintas proposições como referentes. Verbos que introduzem discurso indireto e verbos de atitude proposicional em geral, então, criariam contextos em que as palavras que se seguem passam a se referir ao seu sentido costumeiro, e mapeiam indivíduos e proposições a valores de verdade. De modo que tais verbos estabelecem uma

\footnotetext{
105 Nesses casos, Frege concebe o sentido costumeiro como sendo a referência indireta de uma expressão ou sentença.

${ }^{106}$ Primeiramente, a introdução por Frege da noção de sentido como uma propriedade semântica além da referência foi motivada pelo problema da informatividade de enunciados de identidade do tipo $a=b$, em contraposição à trivialidade de enunciados do tipo $a=a$. Consideremos o exemplo clássico de Frege sobre o planeta Vênus em Sentido e Referência (1892). Se o significado de uma expressão for identificado com seu referente, não podemos explicar por que um enunciado de identidade do tipo "A estrela da manhã é a estrela da tarde" pode ampliar o conhecimento empírico e "A estrela da manhã é a estrela da manhã" não nos informa nada sobre o mundo. Isto é, ao descobrir que "a estrela da manhã" e "a estrela da tarde" referem-se a Vênus, tomo conhecimento de uma descoberta empírica da astronomia. Inclusive, qualquer falante competente do Português compreende "A estrela da manhã é a estrela da tarde" sem que precise saber o seu valor de verdade. No entanto, se o significado de uma sentença fosse identificado com o seu valor de verdade, seria impossível compreender "A estrela da manhã é a estrela da tarde" sem saber seu valor de verdade. Com isso, Frege sustenta que o sentido de um nome próprio - o modo de apresentação de um objeto - é a parte do seu significado que determina o seu referente. A estratégia de mobilizar sentido para tratar de contextos opacos é, por assim dizer, parte do pacote da teoria, no sentido de mostrar como que essa divisão do significado em duas camadas pode ser estendida como modelo explicativo para outros casos desafiadores.
} 
relação entre um falante e uma proposição, e a verdade ou falsidade de (3) e (4) depende de se o referente de Pedro veiculou ou não a proposição a ele atribuída.

A identificação da referência indireta com o sentido costumeiro evita, assim, o problema da substituição em sentenças complementos de verbos de atitude proposicional. Mas resulta numa teoria que postula proposições como entidades passíveis de serem referidas por sentenças. Para a postura chamada de proposicionalista, que toma proposições como explanatoriamente fundamentais num teoria semântica - como tendo um papel central na explicação acerca da nossa compreensão da linguagem que falamos - complementos sentenciais de verbos de atitude proposicional, assim como de operadores modais (,é necessário que considerados o bastião mais robusto em sua defesa. Tais contextos justificariam a tese do papel legítimo do apelo a proposições como parte da ontologia de uma teoria, uma vez que eles sugeririam que proposições compõem a ontologia da linguagem ordinária, entidades que tomamos como podendo ser referidas ou denotadas por expressões e sentenças. Sentenças com essa classe de verbos, também por vezes chamadas de sentenças psicológicas, seriam evidência, na linguagem objeto, para a adoção teórica da noção de proposição.

Recordem que no capítulo I examinamos argumentos robustos, elaborados por Davidson e refinados por Lepore \& Ludwig, contra a necessidade de invocar proposições, ou qualquer forma de reificação do significado de sentenças e expressões subsentenciais, em uma teoria semântica. A conclusão dos autores é de que não há justificativa para a atribuição de proposições às sentenças de uma linguagem objeto com base no assinalamento de sentidos como conteúdos reificados às expressões subsentenciais, porque essa estratégia apenas gera a ilusão de algum progresso explanatório. Ela em si não lança uma luz sobre o significado das sentenças. É o uso de traduções em uma linguagem que já conhecemos que codifica na teoria os significados das sentenças de uma linguagem objeto. Contudo, construções opacas colocam, pelas razões acima expostas, desafios para essa pespectiva. O ônus da prova recai sobre a felicidade de fornecer um modelo explicativo alternativo dos contextos intensionais em que as sentenças complementos não se referem a seus sentidos/intensões. Quer por razões de ordem de utilidade teórica, quer por escrúpulos de natureza ontológica, há na literatura algumas propostas de explicação que intentam evitar uma solução de tradição fregeana. Entre elas, a de Davidson no texto "On Saying That” (1968) ${ }^{107}$, em que uma análise é fornecida particularmente para sentenças de discurso indireto, mas também se aponta a

\footnotetext{
${ }^{107}$ Artigo publicado primeiramente numa edição especial da revista Synthese dedicada ao trabalho de Quine (19(19689), p.130-146). Em seguida foi publicado no livro Words and Objections, Assays on the Work of W. V. Quine, editado por D. Davidson e J. Hintikka, D. Reidel, 1969, p. 158-74, D. Reidel Publishing Compay, Dordrecht, Holland. O texto aparece como o artigo 7 de Inquires into Truth and Interpretation. As citações que fazemos do texto são da edição de 1990 de Inquiries.
} 
viabilidade da mesma proposta ser estendida para setenças de crença, e generalizada também para outras sentenças de atitude proposicional. Mas antes de tratar da estratégia de Davidson, abordarei duas propostas de destaque na literatura sobre o assunto, que antecedem a versão de Davidson e com as quais esta dialóga, e que também intentam percursos que evitam uma referência direta a proposições. Com isso, quero principalmente mostrar que o que hoje são chamados de análises sentencialistas das sentenças de atitude proposicional, i.e., métodos que tratam os verbos de atitude proposicional como relacionando seus sujeitos a sentenças ou enunciados, têm suas primeiras versões em duas propostas anteriores a "On Saying That", e cujas dificuldades que apresentam estimulam Davidson a perseguir uma alternativa. Iniciarei com a análise sugerida por Carnap em Meaning and Necessity (1943), e discorrerei sobre a robusta objeção de Alonzo Church a ela em "On Carnapees Analysis of Statements of Assertion and Belief” (1950). Em seguida, abordarei a análise de Quine em Word and Object (1960). Por fim, percorrerei detalhadamente a solução de Davidson, pontuando o que ela possui de vantagem sobre os métodos anteriores. Concluirei este capítulo destacando alguns problemas com a análise de Davidson, e procurarei mostrar que é essencial que ela apresente explicações convincentes para esses casos, uma vez que eles impõem sérios desafios ao seu escopo explicativo, limitando-a a apenas a um fragmento bem restrito das sentenças de atitude proposicional.

\subsection{A análise de Carnap.}

A solução de Carnap emerge no corpo do método de análise semântica construído por ele em Meaning and Necessity ${ }^{108}$, e rotulado de Método da Extensão e Intensão. Entre as motivações para sua proposta de interpretação das sentenças contendo verbos psicológicos e de introdução de discurso indireto, é importante destacar que ela é elabora como uma estratégia para se evitar uma análise que implique o comprometimento com uma hierarquia infinita de entidades intensionais, como no caso da semântica intensional de Church. ${ }^{109}$ A semântica de MN assinala a cada expressão de uma linguagem objeto uma extensão e uma intensão, e mesmo nos contextos intensionais essa atribuição de apenas duas entidades é preservada. Para ilustrar a análise das sentenças com verbos psicológicos em MN tomemos a seguinte sentença do Português:

5. Galileo acredita que a Terra se move.

\footnotetext{
${ }^{108}$ Doravante abreviado como MN.

${ }^{109}$ Ver Capítulo I.
} 
Uma interpretação sentencialista na linha de Carnap para (5) seria expressa - empregando para o propósito aqui a noção intuitiva de tradução, em substituição ao conceito preciso de isomorfismo intensional (intentional isomorphism) desenvolvido em $\mathrm{MN}$, decisão essa que, em vez de comprometer o que estamos discutindo, facilita para o leitor a sua compreensão ${ }^{110}$ - pela seguinte sentença:

6. Existe uma sentença $S$ em $L$, tal que $(\alpha)$ a tradução de $S$ como uma sentença de $L$ para o Português é „A terra se move e $(\beta)$ Galileo tem a disposição de uma resposta afirmativa à S como uma sentença de L.

Notem que (6) parece analisar (5) como uma sentença em Português sobre uma relação entre o referente do sujeito de ,acredita que e uma sentença de uma língua L, digamos o Italiano, que seria uma tradução da sentença complemento em Português. Nenhuma relação entre o referente de „Galileo e e uma proposição é postulada. É a noção de tradução que cumpre o papel de relacionar o conteúdo semântico da sentença complemento enunciada por um falante com a sentença em L em relação a qual o referente do sujeito de (5) é descrito com possuindo uma disposição linguística. (6), além de evitar referência a uma proposição, descreve um estado psicológico, o de crença, como uma disposição comportamental em tomar uma sentença em uma língua como verdadeira.

A interpretação de tipo carnapiana, todavia, esbarraria no que ficou conhecido como o teste de tradução de Church, que parte da premissa de que uma boa tradução deve preservar os referentes

\footnotetext{
${ }^{110}$ Para introduzir o conceito de isomorfismo intensional Carnap emprega a noção de Equivalência-L, que em MN pode ser estabelecida entre expressões de todas as categorias semânticas e entre expressões de linguagens diferentes. Equivalência-L é definida em MN da seguinte forma: duas expressões A e B são L-equivalentes se, e somente se, „A =

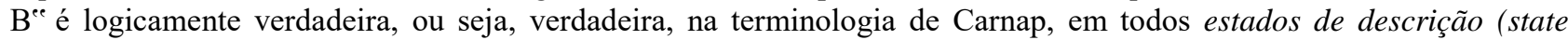
descriptions), e numa terminologia mais contemporânea, em todos os mundos possíveis. Carnap mobiliza então a noção de Equivalência -L para introduzir a noção de „ter a mesma intensão"e. Duas expressões terão a mesma intensão se elas são L-equivalentes, por exemplo, os predicados „Homem “e „Animal Racional““. Equipado com esses conceitos, Carnap caracteriza o que é para as expressões complexas de uma mesma linguagem ou entre linguagens distintas serem intensionalmente isomórficas. Superficialmente falando - mas suficiente para o propósito de pontuar que tal conceito, certamente apresentando condições mais fortes, aproxima-se da noção de tradução, como Carnap destaca em MN, e que pode por ela ser substituído numa formulação mais informal da análise carnapiana das sentenças com verbos psicológicos, não comprometendo o espírito da sua proposta - duas expressões complexas são intensionalmente isomórficas se, e somente se, elas são (i) L-equivalentes e são (ii) construídas (compostas) da mesma forma a partir de espressões L-equivalentes. Em outros termos, elas precisam ter a mesma intensão e a mesma estrutura. Carnap formula este conceito justamente para fornecer uma semântica para os verbos psicológicos. Em MN as linguagens objetos sob análise semântica são linguagens formais, que Carnap chama de Sistemas Semânticos, e as quais são conformadas por um vocabulário e um sistema de regras determinados. O conceito de isomorfismo intensional estabelece uma relação entre pares ordenados de sentenças e sistemas semânticos, de maneira que, tomando dois sistemas semânticos S e S"e duas sentenças $s$ e $s^{\text {"e }}$, a primeira pertendendo à $S$ e a segunda à $S^{\text {"e }}$, e $s$ sendo uma sentença que contenha $o$ verbo ,acredita que e o sujeto $O$, por exemplo, a estrutura em (6) apareceria reescrita como: Existe uma sentença s em um sistema semântico $\mathrm{S}$, tal que $(\alpha)$ s como uma sentença de $\mathrm{S}$ é semanticamente isomórfica a uma sentença $\mathrm{s}^{\text {"e }}$ do sistema semântico $S^{\text {ce e }}(\beta) O$ tem a disposição de uma resposta afirmativa à $\mathrm{S}$ como uma sentença de $\mathrm{S}$. Optamos por empregar a noçao de tradução aqui, por um lado, por estarmos lidando com línguas naturais, e por outro, para tornar mais acessível ao leitor o espirito da proposta de análise das sentenças de atitude proposicional em MN.
} 
dos termos singulares traduzidos. Church observa que a análise (6) acaba tornando uma reportagem sobre a crença de alguém em uma reportagem que relaciona uma sentença de L a uma sentença em Português, de forma que a tradução da análise (6) para o Inglês, por exemplo,

7. There is a sentence $S$ in $L$, such that $(\alpha)$ the translation of $S$ as a sentence of $L$ into Portuguese is „A Terra se move ee and $(\beta)$ Galileo is disposed to an affirmative response to $\mathrm{S}$ as a sentence of $\mathrm{L}$.

resulta em uma tradução para o Inglês de uma análise em Português - (6) - de um sentença em Português (5). Mas para um falante de Inglês que desconhece completamente o Português, (7) não o informa sobre o significado de „A Terra se move $e^{\text {ee }}$ Logo, entende Church, a tradução para o Inglês da análise de uma sentença de crença em Inglês, neste caso, é a análise em Inglês da tradução para o Inglês da sentença original em Português. No nosso exemplo, uma análise em Inglês da tradução abaixo:

8. Galileo believes that the earth moves.

Ou seja, a senguinte paráfrase

9. There is a sentence $S$ in $L$, such that $(\alpha)$ the translation of $S$ as a sentence of L into English is „The Earth movies ${ }^{\text {ee }}$ and $(\beta)$ Galileo is disposed to an affirmative response to $\mathrm{S}$ as a sentence of $\mathrm{L}$.

Desse modo, dado que (6) é uma paráfrase cuja tradução para uma outra língua, no caso o Inglês, só é suficientemente informativa se, de antemão, se sabe que

10. „A Terra se move

então mesmo (6) seria deficitária como uma análise de (5). A conclusão de Church é que a raíz dos problemas apontados está em qualquer análise que, como a de Carnap, menciona uma sentença por meio do mecanismo das aspas - portanto fazer referência a ela via um nome - e a relativiza a uma linguagem.

Em contrapartida, uma análise que simplesmente quantifica sobre uma proposição e a toma como sendo o conteúdo da crença de Galileo, independentemente da língua que emprega, serve de 
interpretação para qualquer sentença, de qualquer língua, que atribui a mesma proposição a Galileo. Por exemplo, as sentenças abaixo

11. Existe uma proposição p, tal que p é a proposição de que a Terra se move e Galileo acredita que $\mathrm{p}$.

12. There is a proposition $p$, such that $p$ is the proposition that the Earth moves and Galileo believes that $\mathrm{p}$.

operam ambas como análises tanto de (5) quanto de (7).

A crítica de Church é desenhada, portanto, como uma objeção à proposta de Carnap, e como um argumento que testemunharia em favor de uma perspectiva proposicionalista.

\subsection{Quine sobre quantificação em contextos opacos.}

Para Quine, contextos opacos (quer criados por operadores modais, quer por verbos de atitude proposicional) e quantificação não podem ser combinados. Isso significa que nenhuma variável dentro de uma construção opaca pode ser ligada por um operador fora dela. Os exemplos mais utilizados por Quine para ilustrar esta tese são sentenças com o operador modal de necessidade. Primeiramente, ele recorre a construções modais sem variáveis para construir seu argumento. É uma verdade da aritmética que

11. 63 é necessariamente maior do que 62 .

Assim como é uma verdade da astronomia que

12. O número de luas de Júpiter $=63$.

Contudo, de (11) e (12) é-se tentado a infere a sentença falsa

13. O número de luas de Júpiter é necessariamente maior que 62.

Com base no princípio de substitutividade, esperia-se que „o número de luas de Júpiter ${ }^{\text {ee }}$ „63e dada sua coextensividade, pudessem ser substituídos em (13), e que (13) fosse verdadeira. Mas isso não ocorre porque em (11) e (13) o operador „necessariamente ${ }^{e e}$ criaria um contexto não extensional. Vimos que, do ponto de vista de um fregeano, pode-se argumentar que a falsidade de (13) decorre 
do fato de nela „o número de luas de Júpiter e e,63 designarem os sentidos que expressam quando aparecem em constuções intensionais. Suspeito quanto ao emprego de entidades intensionais, Quine oferece uma outra tese. Ele restringe o termo „designação “e apenas à ocorrencia das expressões em construções extensionais. Ou seja, somente em tais casos as expressões de uma linguagem designariam um objeto. Enquanto Frege atribui uma outra referência para „O número de luas de Júpiter $^{e e}$ e „63 $63^{\text {ee }}$ contextos intensionais, estendendo assim o princípio de substitutividade para eles, a solução de Quine é negar que em (11-13) essas expressões - nomes e descrições - continuam designando. Para ele, elas parecem perder sua função designativa quando em construções não extensionais. Logo, o princípio de substitutividade não se aplica a essas ocorrências, que ele cunha de „não puramente designativas ${ }^{\text {ee }}$ (not purely designatives).

Uma palavra ou frase substantiva que designa um objeto pode ocorrer de forma puramente designativa em alguns contextos e não puramente designativa em outros. Esse segundo tipo de contexto, embora não menos "correto" do que o primeiro, não está sujeito à lei da substitutividade nem às leis da aplicação e generalização existencial. Além disso, nenhum pronome (ou variável de quantificação) em um contexto do segundo tipo pode se referir a um antecedente (ou quantificador) fora desse contexto (Quine 1943: 127).

Um ponto importante na conclusão acima, e central na análise de Quine são as variáveis. Estas deixariam em construções intensionais de funcionar como em contextos extensionais, de maneira que um quantificador fora de uma construção opaca não poderia ligar a variável dentro dela. Consequentemente, no exemplo

14. $\exists \mathrm{x}$, tal que necessariamente $\mathrm{x}$ é maior que 62

o segundo x ocorreria livre, e (14) deixaria de ser uma sentença. Na verdade se configuraria como uma expressão mal formada. O que implica que não existe uma inferência válida de (13) para (14), ou seja, a generalização existencial também não seria aplicável aos exemplos em questão.

Os contextos de "segundo tipo" são todos não extensionais, e, portanto, devem incluir sentenças com verbos de atitude proposicional. A consequência disso é que Quine terá de fornecer uma análise dessas sentenças que, a princípio, parecem ser interpretadas como se um operador quantificacional ocupasse encobertamente uma posição fora da construção intensional e ligando uma varíavel dentro dela. A seguinte sentença

15. Marcos acredita que um homem é o prefeito de São Paulo. 
pode receber o que na literatura é chamada de „leitura específica ${ }^{e e}$, ou seja, em que Marcos crê que um determinado homem será prefeito de São Paulo. Tradicionalmente, é associada a essa possível leitura a seguinte forma semi-regimentada:

16. $\exists \mathrm{x}$ : x é homem \& João acredita que x é o prefeito de São Paulo.

onde a expressão indefinida é tomada como uma quantifição existencial restrita tendo escopo sobre o verbo „crer ${ }^{\text {ee }}$ Numa abordagem quineana, (16) é uma representação errônea de (15), pelas mesmas razões expostas nos casos anteriores. A variável „,Xe de „X será o próximo prefeito de São Paulo não pode ser presa por,$\exists x^{e e}$. Como, contudo, representar a interpretação específica de (15) partindo dessa premissa? Um modo de fazer isso, sugere Quine, é demonstrar que em (15) „acreditar pode ser concebido como parte de um termo relativo triádico ,acreditar de homem, que ele possui uma propriedade. Por exemplo, se Marcos tiver a crença de que Fernando Haddad é o prefeito de São Paulo, então Marcos acredita, de Haddad, que ele é o prefeito de São Paulo. Assim, Quine representa (15) da seguinte maneira:

17. $\exists \mathrm{x}: \mathrm{x}$ é homem \& Marcos acredita $y[y$ é prefeito de São Paulo $]$ de $\mathrm{x}$.

Na notação de Quine o uso dos colchetes é um mecanismo para indicar que essas expressões estão ocorrendo em contextos opacos. Ele chama esse recurso de ,abstração intensional ${ }^{\text {ee }}$ (intensional abstraction). Essa notação é empregada para distinguí-la da que ele usa para classes, a saber, ,$\hat{y}(\mathrm{~F} y)^{\mathrm{ee}}$, e para indicar que,$y[\mathrm{~F} y]^{\mathrm{ee}}$ pode ser concebida, para o teórico afeito à noção de propriedade, como uma notação para ela. Note que a variável „, $x^{\text {ee }}$ ocorre fora dos colchetes, e, portanto, é interpretada de forma transparente, i.e., extensionalmente, podendo ser ligada pelo quantificador existencial $^{111}$.

Para ficar mais claro esse mecanismo, tomemos uma versão de (15) sem quantificação:

18. Marcos acredita que Haddad é o prefeito de São Paulo.

Neste caso, o termo singular „Haddad“é interpretado na posição da variável em (17):

\footnotetext{
${ }^{111}$ É importante observar que o ,y $y^{\text {ee }}$ que imediatamente antecede os conchetes é parte da estrutura opaca, e, portanto, participa da abstração intensional. Talvez para evitar confusão, o mais adequado seria incluír a primeira ocorrência de ,$y^{\text {ee }}$ também dentro dos conchetes. i.e., algo como [ $y / y$ é prefeito de São Paulo]. Todavia, optou-se por ser fiél à notação de Quine.
} 
19. Marcos acredita $y[y$ é prefeito de São Paulo] de Haddad.

Com os exemplos acima fica fácil também de perceber, voltando para os casos de modalidade, qual paráfrase Quine vislumbra para (11):

20. $x[x$ é maior que 62] é necessário de 63.

onde o termo singular "63e é interpretado numa posição puramente referencial, de forma que pode ser substituído por „o número de luas de Júpitere. Assim, enquando (20) é verdadeira,

21. $x[x$ é maior que 62] é necessário de o número de luas de Júpiter.

é falsa, pelo simples fato de que, no caso das luas de Júpiter, o atributo , $x[x \text { é maior que } 62]^{e e}$ ser contingente.

Essa solução é capaz de extrair as variáveis e termos singulares dos contextos opacos, preservando, assim, a sua função meramente extensional. Para Quine essa realização é uma vantagem fundamental do procedimento, porque, especialmente no caso das variáveis de quantificação, evita ter de atribuir a elas uma intensão, e uma mudança de domínio das entidades que percorrem. E, dado que em Quine o fardo do compromisso ontológico embutido em uma linguagem recai sobre as variáveis de suas expressões ligadas por quantificadores, elaborar uma notação que dispensa reinterpretar variáveis e termos singulares nas posições modais - como no sistema de Church, em que um operador modal toma como argumento uma proposição, e as expressões que formam a sentença sob o operador seus sentidos - implica uma neutralidade quanto a postular que o sentido das expressões sejam entidades. Estratégia que, ainda que não conclusiva, como veremos em seguida, não deixa de testemunhar em favor de se perseguir uma análise dos contextos opacos sem incorrer numa proliferação de entidades intensionais.

Entretando, como Quine destaca, ainda há, nas paráfrases oferecidas, o uso das expressões com a forma,$_{2}[\mathrm{~F} y]^{e e}$, i.e., a notação de abstração intensional. Tal recurso pode sugerir que em (20), por exemplo, , $x[x \text { é maior que } 62]^{\text {ee }}$ funcionaria como um termo designando uma entidade, no caso, uma propriedade. Essa consequência Quine quer também evitar numa análise da modalidade e sentenças de crença, uma vez que, do seu ponto de vista, propriedades e proposições não apresentam critérios razoáveis de individuação, e, por isso, não podem ser adotada como existentes e como objetos de atititudes proposicionais ou como argumentos de operadores modais, ainda que aparentemente possam cumprir um papel explicativo. Mas o que dizer, então, de construções em 
que a quantificação parece ser interpretada sob o escopo de um verbo de crença, indicando que a atitude proposicional não consiste em atribuir uma propriedade a um objeto no domínio de uma variável fora do escopo do verbo, como ilustrado em (17)? Tomemos a sentença

21. Marcos acredita que uma mulher roubou a casa dele.

Ela pode descrever uma situação em que Marcos não tem nenhuma mulher específica em mente, mas está convicto de quem quer que possa ter roubado sua casa, essa pessoa é uma mulher. Ainda (21) pode ser verdadeira até em um contexto em que ninguém roubou a casa de Marcos e que, portanto, sua crença é falsa. É comum vermos tais leituras serem parafraseadas como se segue:

22. Marcos acredita que $\exists x$ : $x$ é mulher \& $x$ roubou a casa dele.

Tendo em vista este tratamento, Quine coloca toda a sentença sob o escopo do verbo „acreditare dentro dos colchetes:

23. Marcos acredita que [uma mulher roubou a casa dele].

indicando sua interpretação opaca. Mas visto desta forma, em (23) [uma mulher roubou a casa dele] não estaria se comportando como o nome de uma proposição, se uma proposição for tomada como o significado de uma sentença? Logo, retornaríamos a conceber ,crer em (21) como estabelendo uma relação entre um indivíduo e uma proposição? Quine apresenta dois percursos para tentar enfrentar essa dificuldade, não sem destacar alguns dos problemas que acarretam e, por conseguinte, seu aspecto inconclusivo.

Em Word and Object, no capítulo "Flight from Intension", Quine sugere adotar sentenças como objetos das atitudes proposicionais. No caso das crenças, por exemplo, uma vez que as coisas que acreditamos possuem valores de verdade e outras propriedades semânticas, os objetos alternativos a proposições podem ser entidades linguísticas como sentenças. Tomemos uma versão da sentença usada por Quine para ilustrar uma possível análise sentencialista:

24. Tom acredita que Cícero denunciou Catilina.

Sendo agora, não mais proposições portadoras de verdade, mas sentenças, o caminho oferecido é de uma paráfrase que recorre a um mecanismo de citação, em que expressões complemento do verbo 
„,crer ${ }^{\text {ee }}$ aparecem entre aspas, operando, então, como nomes de sentenças, e o verbo proposicional é acompanhado do predicado ,verdadeiro ${ }^{c e}$, para explicitar que o referente de „Tom ${ }^{\text {ee }}$ crê verdadeira uma dada sentença:

\section{Tom acredita-verdadeira „Cícero denunciou Catilina ${ }^{e e}$.}

De modo geral, a citação passa a ser uma estrutura que pode, em princípo, ser extrapolada para sentenças de atitude proposicional e modais. Aqui as citaçãos, concebidas como nomes das formas linguísticas que aparecem no seu interior, explicitam que o verbo proposicional continua um verbo relacional, mas agora um dos seus argumentos sendo expressões linguísticas. No caso específico de (25), uma sentença fechada. Contudo, como já vimos, há sentenças de crença em que o objeto da crença atribuída ao sujeito não é uma sentença, como na leitura específica de (15). A solução de Quine é, na paráfrase sentencialista, atribuir ao sujeito da sentença a crença em uma sentença aberta, ou seja, com uma ou mais variáveis livres:

26. $\exists x$ : x é homem \& Marcos acredita ,y é prefeito de São Pauloee de x.

Num paralelo com a abstração intensional, em que a variável quantificada ocorre fora da estrutura opaca, em (26) ela aparece fora da citação. E é isso que se espera, pois uma vez que a citação transforma expressões, sejam elas quais forem, em nomes, ,ye acima se refere à letra do alfabeto, logo não poderia ser presa pelo quantificador existencial. Em outros termos, é impossível um quantificador fora de contextos em que termos são mencionados e não usados, ligar "variáveis" dentro. Por exemplo, em

27. $\exists x$, tal que $x$ escreveu ,x é maior que $62^{\text {ee }}$

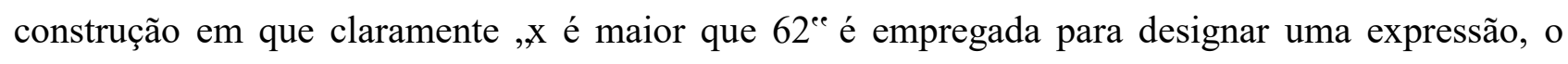
quantificador existencial está estruturalmente bloqueado de prender a "variável" dentro das aspas. ${ }^{112}$ Nesse sentido, a similaridade do comportamento da quantificação em construções modais/de atitudes proposicionais com as construções com citação, fomenta uma saída sentencialista que toma a citação "como forma vívida à qual reduzir todas as outras construções opacas" (Quine 1960: 212). Mas as paráfrases (25-26) não contam ainda toda a trama. Uma sentença, sendo um padrão repetível

\footnotetext{
${ }^{112}$ Exemplo adaptado de Quine (1960: 166).
} 
de som, é sempre relativa a uma linguagem. De maneira que, se crer, é crer em uma sentença, ou melhor, em types de sentenças, então é sempre crer que uma sentença de uma dada língua é verdadeira. Assim, se Tom é um monolíngue falante de Português, um argumento para uma linguagem precisa ser introduzido na paráfrase sentencialista:

\section{Tom acredita-verdadeira em Português „Cícero denunciou Catilina ${ }^{e e}$}

Se essa for a maneira mais adequada de se parafrasear (24) via referência a uma sentença, então de imediato aparece a mesma dificuldade notada por Church na análise de Carnap. E Quine, presumivelmente, não deixa de observar esse problema. Uma tradução para o Inglês de (28) seria

\section{Tom believes-true in Portuguese „Cícero denunciou Catilina}

na qual o referente da expressão entre aspas é preservado, uma vez aceito que um termo referencial, seja ele simples ou formado por citação, deve preservar o mesmo referente quando traduzido. Um falante monolíngue de Inglês, ignorante quanto ao Português, no entanto, a partir de (29) não entenderia o significado da sentença atribuída a Tom. Isso ocorreria somente com uma completa tradução de „Tom acredita que Cícero denunciou Catilina Inglês, somente o significado de (28), e que, uma vez que a tradução (28) por si só não dá acesso ao significado de (24), então mesmo (28) falharia como análise de (24).

Quine propõe, então, ao invés de interpretar as sentenças complementos de verbos de atitude proposicional como relativas a uma linguagem, parafraseá-las como enunciadas por um falante, o que resulta em interpretá-las relativas a quem as expressa.

Seria melhor se referir aqui não a uma linguagem $l$, mas a um falante $z[\ldots]:, w$ acreditaverdadeira $s$ no sentido de $z^{\text {ee }}$. Teríamos então um termo relativo triádico irredutível ,...acredita-verdadeira...no sentido de... ${ }^{e}$, relacionando um homem, uma forma línguística e um homem. (Quine 1960: 214).

Nessa acepção, o substituto de ,Z̋e é quem enuncia a sentença de atitude proposional, de maneira que (24) pode ser interpretada como: "Tom acredita numa sentença que tem o mesmo sentido que „Cícero denunciou Catilina ${ }^{e e}$ tem para mim”. Ou seja, o falante indiretamente atribui a Tom a crença em uma sentença, e relaciona o sentido dessa sentença com o sentido que a sentença complemento 
tem relativa a ele, falante. ${ }^{113}$ Entretanto, coerente com sua suspeita da noção de „mesmo significado ${ }^{e e}$,i.e., „sinonímia ${ }^{e e}$, com base em parte no mesmo argumento para linguagens - de que um princípio de individuação para determinar quando duas sentenças têm o mesmo significado é obscuro - Quine propõe uma última alternativa: manter o método de abstração intensional, mas dispensar as entidades que tal método a princípio parece pressupor.

O raciocíneo parece ser o seguinte: por um lado, adotar sentenças relativizadas a uma linguagem como sendo os objetos das atitudes proposicionais fracassou, em função da plausível força da objeção de Church, mas também é uma saída suspeita por causa da ausência de critérios de individuação claros na determinação de uma linguagem. Por outro lado, a relativização das sentenças complementos a quem as enuncia pede a introdução da noção de identida entre sentidos de sentenças, também uma noção bastante indeterminada. Ao cabo, portanto, esses dois esboços sentencialistas aparentam não ser mais promissores do que o método da abstração intensional. Em vista disso, Quine sugere, como último passo, no desfecho dos seus ensaios de paráfrases para sentenças de crença, no capítulo já referido, abandonar a tendência a conceber a abstração intensional como um mecanismo formador de nomes de entidades intensionais, e tratar ,acreditar

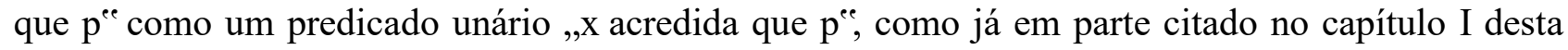
tese e retomado abaixo:

Podemos continuar a elaborar as atitudes proposicionais com a ajuda das notações de abstração intensional, [...] mas apenas deixar de ver essas notações como termos singulares. Isso significa ver „Tom acredita [Cícero denunciou Catilina] ${ }^{\text {"e }}$ não mais como da forma ,Fabee, com $a=$ Tom e $b=$ [Cícero denunciou Catilina], mas ao invés como tendo a forma , $F a^{\text {ee }}, \operatorname{com} a=$ Tom e o compleo „, $\mathrm{F}^{\mathrm{ee}}$. O verbo, acreditar ${ }^{\text {ee }}$ aqui deixa de ser um termo e se torna parte de um operador, acredita que ,acredita [ ] $]^{\text {ee }}$, que, aplicado a uma sentença, produz um termo geral absoluto [absolute general term] do qual a sentença é um constituinte imediato. De forma semelhante o verbo ,acredita ${ }^{c e} \mathrm{em}$ „Tom acredita $y[y$ denunciou Catilina $]$ de Cícero ${ }^{\text {"e }}$ torna-se parte de um operador que liga variáveis [variable-binding operator] e o qual, aplicado diretamente à sentença aberta ,y denunciou Catilina ${ }^{e e} \mathrm{e} \mathrm{à} \mathrm{variável} \mathrm{,y} \mathrm{y}^{\mathrm{ec}}$, produz o termo geral relativo [relative general term], acredita $\mathrm{y}[y$ denunciou Catilina] de e. Do mesmo modo para duas ou mais variáveis e para outros verbos de atitude proposicional. [...] No seu novo status de não serem termos, os abstratos intensionais permanecem, irredutivelmente, como partes de termos gerais compostos. Termos gerais, por seu turno, cessam de sempre contar como simples do ponto de vista da notação canônica, e passam a admitir sentenças fechadas ou abertas e variáveis como constituintes imediatos (Quine 1960: 216).

\footnotetext{
${ }^{113}$ Como o leitor verá na próxima subseção, esta proposta de Quine se assemelha à paráfrase que Davidson propõe do verbo ,dizer" em construções de discurso indireto. E Davidson não deixa de conceder a Quine o mérito de indicar a viabilidade desse percurso.
} 
Um primeiro ponto importante a notar nesta proposta é que ela intenta ser uma explicação não

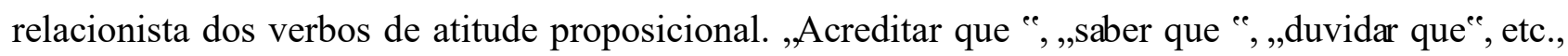
formam um operador que toma uma sentença como argumento, constituindo assim um termo geral, ou seja, um predicado unário, que se aplica a um indivíduo. Essa seria, portanto, a função sintática do operador ,verbo-que ${ }^{e}$. Do ponto de vista prático, essa solução intenta incorporar esses verbos a uma semântica composicional. Por si só ela aparece como uma saída parcial, uma vez que não fornece uma semântica para o operador. Mas é perceptível na passagem acima que Quine a formula com o intento de evitar que o seu tratamento dos contextos opacos via o mecanismo da notação da abstração intensional o comprometa com tratá-los como nomes e, portanto, como termos que designam algo: se a abstração intensional é de uma sentença, ela designaria uma proposição, se de um predicado, uma propriedade. O desafio essencial para Quine, lembremos, era em primeiro lugar apresentar uma notação que extraísse as variáveis quantificadas dos colchetes intensionais, salvando a sua função extensional e evitando ter de atribuir uma intensão a elas. Com isso, ao demonstrar que sentenças em que variáveis que aparentemente ocorrem dentro das construções opacas podem ser reescritas com as variáveis fora da abstração intensional, Quine prova que há uma saída, digamos, técnica, em uma notação canônica, para a sua suspeita da viabilidade de quantificadores ligarem variáveis “opacas”. Esse é um feito admirável, sobretudo do ponto de vista de um extensionalista, pois se configura como uma solução técnica em face de suspeitas de ordem ontológica. Ou seja, de que é possível que as variáveis para indivíduos não sejam afetadas por complicações postas pelos contextos opacos, preservando os mesmos objetos na sua extensão. Entretando, como extensionalista radical, Quine não se contenta com essa resolução, e quer dispensar tratar as expressões complemento dos verbos de atitude proposicional como nomes.

Ainda que a explicação desses verbos em termos de constituintes de um operador exiba um resultado composicional em que o aspecto relacional do verbo é sintaticamente eliminado, não é apresentada uma explicação semântica de como o operador toma uma sentença aberta ou fechada, e a transforma em uma sentença que sofre uma abstração intensional. Parece-me que essa lacuna na narrativa precisaria ser preenchida, pare que se tenha de fato uma explicação não relacional desses verbos mais conclusiva. Independentemente disso, há dois méritos inegáveis do percurso traçado por Quine na passagem acima: (i) de que o vocabulário do discurso sobre construções intensionais não deve ser tomado ao pé letra (at face value), pois é plausível de se construir alternativas ao caminho dominante e mais à disposição, i.e., de se assumir verbos psicológicos como expressando uma relação entre indivíduos e entidades chamadas de proposições - entendidas como conteúdos das atitudes; (ii) e que nem a noção de que esses verbos sejam relacionais, sejam quais forem os objetos dessa relação, pode ser tomada como uma premissa já estabelecida e inquestionável. 
Um segundo ponto a destacar é que a proposta de conceber ,acreditar que como um operador formador de predicados unários complexos parece conflitar, para Davidson, com uma das condições reguladoras de uma teoria formal do significado: apresentar a linguagem objeto como possuindo um vocabulário finito. Lembremos que é essa a objeção que Davidson levanta contra esta análise em TMLL, como examinado no capítulo I. Simplificadamente, o argumento é de que, uma vez que o número de sentenças que podem ser complemento de ,acreditar que é infinito, segue-se que a lista de predicados unários complexos resulta infinita. Essa consequência, se extraída de uma análise semântica, apresentaria a linguagem objeto investigada como impossível de ser aprendida. O eixo da crítica de Davidson à solução de Quine se centra fundamentalmente neste aspecto. Nenhuma posição é elaborada acerca das paráfrases sugeridas para as construções opacas. Em verdade, o esforço de Quine em oferecer explicações que evitem a quantificação em construções opacas e que apontem a viabilidade de uma alternativa sentencialista, motivou a convicção de Davidson de que uma análise não proposicionalista dos contextos intensionais deve ser perseguida. A tese paratática de Davidson, que examinaremos em seguida, é fruto dessa direção apontada por análises como a de Quine. No que se refere à objeção ao tratamento de „crer que ${ }^{e e}$ como operador, considero-a no mínimo inconclusiva. Para concluir essa seção, quero colocar duas observações em defesa de Quine.

A primeira é que não creio que o requerimento de um vocabulário finito deva incidir sobre predicados complexos. Se a condição de finitude é correta, é suficiente restringí-la ao vocabulário básico, pois se regras de composição de predicados complexos forem introduzidas, basta o domínio de tais regras, o conhecimentos das expressões básicas que compõem esses predicados complexos, e seu modo de combinação, para formar o significado desses predicados novos. E Quine fornece, embora ainda de maneira vaga, demandando uma elaboração mais refinada, justamente um método que contempla essas condições. Tomemos a sentença „Cícero denunciou Catilina ${ }^{e e}$. Ela, antes de ser tomada pelo operador, pode ser formada a partir de cláusulas de satisficação para os termos singulares „Cícero ${ }^{e e} \mathrm{e}$ „Catilina ${ }^{e e}$, e para a função predicativa relacional „x denunciou $\mathrm{y}^{\text {ee }}$. Uma vez construída, o operador ,acreditar que a toma como argumento, para então gerar o predicado complexo „x acredita que Cícero denunciou Catilina ${ }^{e e}$, que poderá também receber uma cláusula de satisfação. E da composição do predicado complexo com o termo „Tome, temos „Tom acredita que Cícero denunciou Catilina ${ }^{e e}$. Não é dificíl de entrever como todas as etapas composições dessa sentença podem ser incorporadas a uma teoria axiomática da verdade, em que uma sentença-T para ela é composicionalmente fornecida. É verdade que se o propósito for de exibir uma regra para o operador „crer que ${ }^{e e}$ que especifique como que ele, aplicado a uma sentença, a retorna como um termo geral a ser interpretado opacamente, algo mais é preciso introduzir, pois o que Quine oferece 
é apenas uma regra sintática de formação desses predicados complexos. Alguém poderia argumentar que o que faltaria à estratégia é uma integração entre as paráfrases sugeridas e o papel composicional do operador. Contudo, não creio que Quine veja isso como um requisito. Ele não tem a pretensão de fornecer uma teoria do significado. Aliás, Quine é cético quanto à viabilidade de uma semântica sistemática para as línguas naturais. Talvez a mensagem da sua proposta de tratar „,acreditar que cemo um operador formador de termos gerais é justamente de demonstrar que o seu papel composicional pode ser especificado dessa maneira. Ficando o papel da interpretação dos significados das sentenças em que tais operadores aparecem ao plano das paráfrases em notação canônica. Quine não pretende e nem espera que ambas as estratégias sejam coordenadas coerentemente no corpo de uma teoria semântica. Mas mesmo que faltasse um aprimoramento do papel composicional desses operadores, essa lacuna também me parece imune à crítica de Davidson. Pois, ainda que parcial, a tese dos operadores justamente permite que não tomemos os predicados complexos formados com sua ajuda como um todo não analizado. Um dos méritos da tese é não esconder a estrutura interna desses predicados.

\section{O método paratático de Davidson para o discurso indireto.}

O comportamento de sentenças compostas cujo valor de verdade não depende, ao menos de forma óbvia, do valor de verdade das suas sentenças constitutivas, dificulta a sua incorporação a uma teoria semântica da forma proposta por Davidson. A princípio, é difícil conceber como sentenças de discurso indireto, em particular, e de atitudes proposicionais em geral, podem receber um tratamento que define satisfação para sentenças complexas em termos de satisfação das sentenças que a formam. Ou seja, um tratamento puramente extensional dessa classe de sentenças, que dispensa propriedades e proposições, tem de enfrentar de forma convincente o problema de que termos coextensivos, quando em contextos opacos, parecem não ser substitutíveis salva veritate. Dado que o valor de verdade de uma sentença como

30. Galileo disse que a terra se move.

parece não ser determinado pelas propriedades extensionais dos termos na sentença complemento do verbo principal, o desafio posto é: como encontrar uma estrutura recursiva de tipo tarskiana uma vez que há em potencial um número infinito de sentenças da forma 'Galileo disse que p' - que acomode nossa habilidade de compreender um número infinito de sentenças de discurso indireto não sinônimas em que a estrutura 'Galileo disse que ' é constante e as sentenças complemento variam? 
Parte do sucesso ou fracasso do programa davidsoniano como uma teoria semântica não restrita tão somente aos contextos ditos extensionais das línguas naturais depende da viabilidade de propor uma explicação satisfatória da estrutura semântica de sentenças com verbos de atitude proposicional. Sentenças de discurso indireto estão na "lista impressionante de dificuldades e enigmas que permanecem" (Davidson 1990 [1967]: 35) e com os quais "uma teoria compreensível do significado deve lidar com sucesso" (idem).

A proposta de Davidson aparece pela primeira vez em "On Saying That" (1968), no qual é concebida sua análise paratática do discurso indireto, e indicada a plausibilidade de sua ampliação para as sentenças de crença.

$\mathrm{Na}$ estratégia de Davidson, sentenças de discurso indireto operam semanticamente como duas sentenças, e a seguinte forma é atribuída à (29):

31. Galileo disse (que -demonst $^{114}$. A terra se move.

onde na primeira sentença de (30) o termo 'que -demonst' é concebido como um pronome demonstrativo que, quando empregado num enunciado como (30) se refere ao enunciado ,a Terra se move ${ }^{e e}$, que é a uma realização concreta, em uma situação de fala, de uma sentença. 'que -demonst' é construído como um termo referencial, mas cujo referente é um enunciado que se seque ao enunciado „Galileo disse (que ${ }^{- \text {demonst }}$ ) ${ }^{\text {ee }}$. Por isso, a denominação de análise paratática do discurso indireto. Parte da originalidade da análise é justamente tomar tais sentenças como sendo estruturalmente duas. Nesta estratégia Davidson vincula, de forma forte, os conceitos de enunciado e ato de fala, no sentido de que um enunciado, como ato linguístico concreto, circunscrito a uma situação de fala, configura-se como um ato de fala. Propõe o filósofo:

...seria melhor, ao lidar com esse assunto, falar em [...] enunciados e atos de fala, e evitar referência a sentenças. Pois o que um enunciado de "Galileo disse que faz é anunciar uma outra sentença. Como qualquer enunciado, esse primeiro pode ser bobo, assertivo ou brincalhão (Davidson [1968] 1990: 106-107) ${ }^{115}$.

\footnotetext{
${ }^{114}$ Davidson evidentemente usa o exemplo de (29) em Inglês, que é 'Galileo said that the earth movies'. Em Inglês, o pronome ,that' pode funcionar tanto como pronome relativo quanto como pronome demonstrativo. No caso do Inglês, há lastro para tratar ,that ${ }^{\text {ee }}$ no discurso indireto como um demonstrativo. Visto que não temos em Português uma correspondência de forma entre um pronome relativo e um pronome demonstrativo, optei pela representação ,que demonst' para indicar ao leitor que estou tratando aqui o pronome 'que' como um demonstrativo.

${ }^{115}$ Essa postura suscita, sem dúvida, questões, pois toca num problema bastante controverso na literatura acerca dos portadores de verdade: são eles sentenças, enunciados/atos de fala ou proposições? Problema esse que está colocado para o programa proposto por Davidson, que precisa relativizar o predicado „é verdadeiro “e a falante e tempo, em especial nas sentenças/enunciados/atos de fala com termos demonstrativos. Essa controvérsia tem implicações para uma divisão ou não entre semântica e pragmática.
} 
O que temos, então, são dois enunciados, sendo que o primeiro se refere ao segundo. Desse modo, o que alguém assevera ao dizer (30) é „Galileu disse que ${ }^{\text {ee }}$, com „que ${ }^{\text {ee }}$ se referindo ao enuncidado „A Terra se moveee, o qual não precisa ser asseverado. É evidente, no entanto, que Galileo não enunciou o próprio enunciado „A Terra se move ee (29), pois quem o enuncia é quem diz ou escreve (30). É muito provável que Galileo nem sequer falasse Português. E é justamente esse aspecto o mais definidor da particularidade semântica de tais sentenças.

Por isso, um elemento nuclear da abordagem de Davidson é a noção de ,samesaying' (dizero-mesmo), introduzida para indicar que se digo (30), ela é verdadeira se, e somente se, Galileo disse uma sentença que significou na sua boca o mesmo que „A Terra se move $e^{\text {ee }}$ significou na minha. Do que se segue que ,samesaying ${ }^{c e}$ aparece como um predicado relacional diático, que estabelece uma relação entre dois enunciados: no caso de (30), entre o enunciado em Português ,,a terra se move ${ }^{\text {ee }}$ um enunciado dito por Galileu, provavelmente em Italiano ou Latim. Mas o que significa dizer que um enunciado do falante $f_{1}$ samesays um enunciado de $f_{2}$ ? Naturalmente, a tendência é que um enunciado da sentença $p$ samesays um enunciado da sentença $q$ quando ambas são sinônimas, possuem o mesmo significado (no contexto de uso) ou quando uma pode ser compreendida como tradução da outra. ${ }^{116}$ Contudo, notem que definir ,samesaying ${ }^{\text {ee }}$ em termos das noções de tradução ou sinonímia - para além do fato de tais conceitos serem de difícil definição - coloca problemas se atentarmos para casos de discurso indireto que tendemos a tomar como verdadeiros, ainda que não possamos neles pensar em termos de tradução e sinonímia ${ }^{117}$. Observemos o seguinte exemplo:

32. João: Eu preferiria morrer a perder o show dos Rolling Stones.

Laura: João disse que não perderá por nada o show dos Rolling Stones.

Dificilmente julgamos a fala de Laura como sendo falsa, porque não seria uma referência acurada à fala de João. Tendemos a tomar o que Laura disse como verdadeiro. Se ,samesaying ce consiste em uma relação entre enunciados e não sentenças, e a consideramos como uma noção aplicável ao caso (32), fica difícil explicá-la com os conceitos semânticos mencionados, pois discursos indiretos muitas vezes mais parafraseam do que expressam estritamente o mesmo conteúdo semântico de outras sentenças enunciadas. Tendo esse desafio em perspectiva, Cappelen e Lepore (1999) propõem uma abordagem interessante desta noção introduzida por Davidson. „Samesaying ${ }^{\text {ee }}$ seria um conceito relacional primitivo determinado pelas práticas, em contextos comunicativos, de emprego dos discursos indiretos. Ou seja, que enunciado samesays outro enunciado é fixado pela

\footnotetext{
${ }^{116}$ Ver no capítulo V, o debate em torno desses conceitos na semântica de Davidson.

${ }^{117}$ Ver Cappelen \& Lepore 1997 e 1999.
} 
própria prática da citação indireta. Seria próprio nos contextos de discurso indireto, por exemplo, não impor restrições rigorosas sobre o que pode ser considerado como dizendo o mesmo. De maneira que o que pode ser visto como uma má tradução, ou um enunciado claramente não sinônimo do enunciado reportado, ainda assim pode ser tomado como um discurso indireto verdadeiro. Essa explicação substancialmente circunscrebe ,samesaying ${ }^{\text {ee }}$ ao plano pragmático, onde é suficiente que essa noção seja empregada para, digamos, rastrear as práticas e fatos envolvidos na determinação do que é considerado como um discurso indireto adequado. Logo, a explicação de „,samesaying ${ }^{\text {ee }}$ mediante conceitos semânticos não daria conta de capturar os casos de enunciados que reportam enunciados, e que frequentemente não significam o mesmo que reportam. Pensem, por exemplo, nos vários casos em que nos reportamos a uma fala de alguém com ironia, sarcasmo, ou metaforicamente. Enfim, destacar o aspecto fundamentalmente pragmático deste conceito é o suficente aqui para elucidar que Davidson, ao empreender, no caso do discurso indireto, uma análise baseada mais na noção de enunciado do que de sentença, intenta forjar ,samesaying ${ }^{\text {ee }}$ como um predicado primitivo, e que, portanto, não precisa receber uma definição, mas que lastreia e abarca não somente os discursos indiretos em que parece que quem reporta está veiculando o mesmo conteúdo do que é reportado, como casos semelhantes à (30), em que essa restrição não é necessária para que uma reportagem adequada se realize. A proposta de Cappelen e Lepore (1999), que retoma e desenvolve a análise de Davidson, ainda que venha a se revelar inconclusiva, indica que é justificável empregar ,samesayingee sem incorrer numa reintrodução da reificação do significado, não mais como referência da sentença complemento, mas como pressuposto embutido na noção de ,,samesaying ${ }^{e e}$, como pensou Foster (1977). Objeção essa que à luz de uma interpretação mais detalhada dos conceitos envolvidos na proposta de Davidson aparece como precipitada, como argumentaremos ainda neste capítulo. Elucidados esses pontos, voltemos aos detalhes técnicos da análise paratática, e a partir deles pontuemos vantagens importantes dessa alternativa, bem como algumas desvantages ou desafios que ela acarreta e que pedem explicações mais convincentes.

As duas passagens a seguir de "On Saying That" ilustram bem, do ponto de vista da análise paratática, como se daria a interpretação de enunciado de discurso indireto do tipo (29):

Galileo enuncia suas palavras „Eppur se muove move $^{\text {ee }}$. Não há problema [...] em reconhecer que somos samesayers; um enunciado meu corresponde a um enunciado dele em significado. Não estou agora usando minhas palavras para ajudar a se referer a uma sentença; eu falo for mim mesmo, e minhas palavras se referem do seu modo usual a terra e seu movimento. Se o enunciado „Eppur si

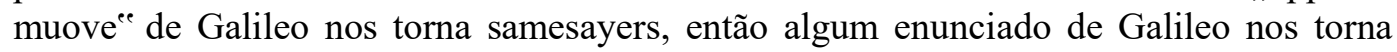
seamesayers. A forma (o enunciado $\mathrm{x}$ de Galileo e meu enunciado y nos torna samesayers) "é então um modo de atribuir qualquer dito que me agrada a Galileo, contanto que encontre um modo de substituir, $\mathrm{y}^{\text {ee }}$ por uma palavra ou frase que se refere a um enunciado meu que seja apropriado. E certamente há um modo em que posso fazer 
isso: preciso somente produzir o enunciado esperado e substituir ,y por uma referência a ele (Davidson [1968] 1983: 105).

E, mais à frente, após citar uma passagem do dicionário Oxford de Inglês, no qual consta que, diacronicamente, o uso de 'that' como pronome relativo se originou do seu uso como demonstrativo, Davidson sintetiza sua tese:

A proposta então é a seguinte: sentenças em discurso indireto [...] têm a sua forma lógica dentro da manga [...]. Elas consistem de uma expressão que se refere a um falante, o predicado de dois lugares ,disse $e^{e e}$, e um demonstrativo se referindo a um enunciado. Ponto final. O que se segue apresenta o conteúdo do que é dito pelo sujeito, mas não tem nenhuma conexão lógica ou semântica com a atribuição original de um ato de dizer. Esse último ponto é sem dúvida o ponto novo, e dele tudo depende: de um ponto de vista semântico a sentença-conteúdo no discurso indireto não está contida [...] na sentença que termina com ,that" (Davidson [1968] 1990: 106).

Trata-se de uma estratégia na qual,$x$ disse que $p^{\text {ee }}$ envolve referência a um enunciado do falante que está relacionado com um enunciado de x porque $\mathrm{p}$,samesays ${ }^{\text {ee }}$ um enunciado dito/escrito por $\mathrm{x}$. Notem que o verbo „dizere permanece sendo um termo relacional, um predicado de dois lugares, mas que tem um pronome demonstrativo como argumento, o qual, por sua vez, se refere a um enunciado $p$. O resultado é também uma análise relacional das sentenças de discurso indireto, mas atribuindo a um indivíduo um enunciado referido por intermédio de um pronome demonstrativo.

À luz dessa proposta, então, o primeiro enunciado da sentença (30) é representado como tendo as seguintes condições de verdade (relativizando (30) à falante e tempo, de modo a acomodar aspectos sensíveis ao contexto nas línguas naturais):

33. „Galileo disse que é verdadeira $[f, t]$ em Português $\leftrightarrow \exists \mathrm{t}^{\mathrm{ee}}: \mathrm{t}^{\mathrm{ec}}<\mathrm{t} \wedge$ Galieu diz em $\mathrm{t}^{\mathrm{ee}} r e f\left(\right.$,que ${ }^{\mathrm{ee}}, f$, $t)$.

onde ,f „,é a variável para falante, ,fֹ para o tempo no qual o enunciado „Galileo disse que é produzido, „tee remetendo ao tempo do enunciado de Galieo que antecede t, por isso o uso de „, Por sua vez, ,ref(,que $\left.{ }^{e e}, f, t\right)^{\text {ee }}$ deve ser lida como ,, a referência de ,que ${ }^{e e}$ falada por $f$ em $t^{\text {ee }}$. Ou seja, „ref(,que $\left.{ }^{e e}, f, t\right)^{\text {ee }}$ instanciado para falante e tempo resulta no objeto demonstrado pelo falante com o uso de „que

Com o propósito de elucidar como deve ser interpretado o verbo „dizere numa construção de discurso indireto como (30), Davidson fornece a seguinte paráfrase, na qual é empregado o termo técnico,samesayse: 
34. $\exists x$, tal que $x$ é um enunciado de Galileo e meu último enunciado, ,a terra se move samesays $\mathrm{X}$.

Esta paráfrase deve elucidar um aspecto do significado do verbo que não é explicitável nas condições de verdade (33) fornecida por uma teoria-T. ,samesays é empregado em (34) mais como um termo usado de forma heurística para capturar uma parte do significado de „dizere quando no discurso indireto, e que não é ,visívele ${ }^{e e}$ uma teoria da verdade. Retornarei a este ponto quando abordar a interpretação de Foster sobre a noção de „samesayingee, na parte sobre os desafios da proposta e críticas a ela.

Por ora, é fundamental sublinhar que, com sua análise paratática, Davidson crê dissolver os contextos intensionais criados por sentenças como (30). Isso porque o verbo ,dizere, interpretado como uma relação extensional estabelecida entre um falante e um enunciado, viabilizaria a incorporação de sentenças do tipo (30) a uma teoria da verdade extensional.

\subsection{Vantagem da análise paratática.}

Há uma realização importante e distintiva da abordagem de Davidson que outras alternativas não proposicionalistas não alcançaram. A aparente violação do princípio de substitutividade nas sentenças de discurso indireto recebe uma explicação extensionalista, mas sem precisar recorrer à ideia de que em tais construções os termos mudam seu significado ou referência. Trata-se de uma análise que preserva a chamada "inocência semântica" das expressões linguísticas. A mudança aparente de significado é explicada pelo fato de, equivocadamente, tomarmos duas sentenças independentes por uma. Nesse sendido, sendo „Galileo disse que e , ,a terra se move “e “...] semanticamente independentes, não há razão em predizer, com base somente na forma, qualquer efeito particular sobre a verdade da primeira a partir da mudança na segunda" (Davidson 1990

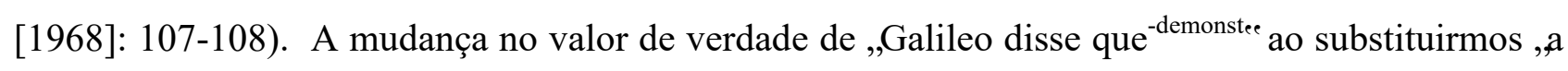
terra ${ }^{e e}$ por „o terceiro planeta do sistema solar ${ }^{\text {ee }}$, decorre do fato de, com essa substituição, o referente

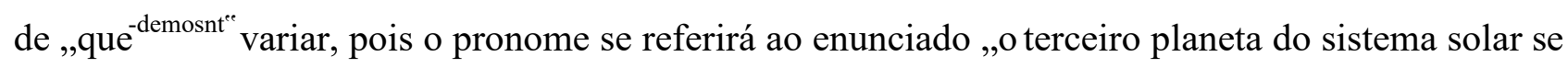
move . O mérito dessa explicação é justamente o fato de nela as unidades constitutivas de ,a terra se move $^{e e}$,, terceiro planeta do sistema solar se move em contextos opacos preservarem sua extensão, isto é, não alterarem, por meios obscuros, a sua referência. Em (30) o referente de ,a terrac é a própria terra, não um conteúdo abstrato reificado, ou a própria expressão dentro das aspas, etc. Por isso, Davidson demarca sua análise, se apropriada, como uma alternativa efetiva a um tratamento de inspiração fregeana, e que apresenta uma solução para a seguinte ambição: 
Desde Frege, filósofos têm se apegado à ideia de que as sentenças-conteúdo em discussões sobre atitudes proposicionais podem estranhamente se referir a entidades como intensões, proposições, sentenças, e inscrições. O que é estranho não são as entidades, que estão todas em seus devidos lugares (se tiverem algum), mas a noção de que palavras comuns para planetas, pessoas, mesas, hipopótamos no discurso indireto podem trocar sua referência usual pelas exóticas. Se pudéssemos recobrir nossa inocência pré-fregeana, penso que pareceria para nós claramente incrível que as palavras „A Terra se move", enunciadas depois das palavras „Galileo disse que", significam qualquer coisa diferente, ou se referem a qualquer coisa que não seja de seu costume quando aparecem em outros ambientes [...]. A linguagem é o instrumento que é porque a mesma expressão, com as características semânticas (significados) não alteradas, pode servir a incontáveis propósitos (Davidson 1990 [1968]: 108).

Se (33) for toda a história da contribuição composicional do verbo „dizere para as condições de verdade de „Galileo disse que ex exibidas em uma teoria da verdade, então o método paratático consegue atribuir uma estrutura às sentenças de discurso indireto, fundamentalmente às expressões das sentenças complementos do verbo ,dizer que ${ }^{e e}$, em que as palavras preservam o significado e referência atribuídos a elas nos contextos extensionais. Logo, na teoria, será suficiente um axioma para „Terra ${ }^{\text {ee }}$ um para o verbo „moveree, que nos dá suas condições de satisfação. E é evidente, se assim o for, que essa seria uma vantagem substancial, no sentido de demonstrar que com um método extensional pode se chegar mais longe do que comumente se considera. Para tal, nem mesmo foi necessário recorrem à ideia de que em contextos opacos o que se tem são nomes de sentenças, como na sugestão de Quine. Além de radicalmente extensional, ela evita os problemas da estratégia da citação e sua referência a uma linguagem particular.

\subsection{Desafios da análise paratática.}

Os desafios postos para o método de Davidson surgem de uma série de objeções levantadas por línguístas e filósofos a ele. Não listarei todas aqui. Apenas me deterei nas que considero mais importantes e recorrentes. Onde creio que haja contra argumentos para rebater algumas das objeções, eles serão exibidos. Por razão de ser parte do importante debate entre Davidson e Foster sobre os limites do seu projeto semântico, em que aquele é estimulado a responder às críticas deste e, por isso, elucidar melhor também a sua proposta paratática, dedicarei uma atenção especial aqui a esse ponto das objeções de Foster. Como ficará ainda mais percepitível deliberadamente no último capítulo, desafios fundamentais para aquilo que a semântica de Davidson ambiciona cumprir intersectam, não por acaso, com questões presentes na análise paratática do discurso indireto.

Iniciememos pela objeção de ordem sintática, distribuída em três pontos. Parece haver um conflito entre a sintaxe de „Galileu disse que a Terra se move e a proposta paratática, se generalizarmos essa análise para todas as línguas. „That eem Inglês é usado como demonstrativo, e Davidson recorre a este fato para defender que, mesmo em discurso indireto, „that é um pronome. 
E há base diacrônica para isso, como Davidson mesmo ilustra, em "On Saying That", com uma passagem do dicionário Oxford de Inglês, no qual se pontua que "é geralmente sustentado que o uso de „that ${ }^{\text {ee }}$ surgiu do uso demonstrativo do pronome apontando para a oração que ele introduz”. ${ }^{118}$ Todavia, os termos correlatos em outras línguas, como „que em Português e Francês, não são empregados como demonstrativos. ${ }^{119}$

Outro problema é listado por Hand (1991), que demonstra que em Inglês há relações estruturais de subordinação que ocorrem entre a sentença complemento e a sentença principal no discurso indireto que a análise paratática não captura, gerando inclusive uma interpretação errônea do significado da sentença complexa. Tomem a sentença em Inglês

35. I didn"et say that I went anywhere.

Numa análise paratática interpreta-se (33) como

36. I didn ${ }^{e e}$ say that. I went anywhere.

De acordo com Hand, se tratarmos (35) como (36), o resultado é que (35) é verdadeira somento no caso em que eu não enunciei algo que samesays „I went anywhere ${ }^{\text {ec }}$. Como sentença sozinha, „I went anywhere é é considerada não gramatical em Inglês. Além disso, na análise paratática ela é apresentada como semânticamente independente de „I didn ${ }^{e e}$ say that ${ }^{\text {ee }}$. E o problema é que (35) é interpretada pelos falantes de Inglês como significando „I didnè say I went somewhere ${ }^{\text {ee }}$. Numa teoria sintática essa especificidade da interpretação de (35) reside na interação estrututural entre a sentença principal e a complemento e em como essa interação afeta e é afetada por operadores existenciais e de negação. Mas como acomodar em uma sintaxe de tipo paratática este comportamento de sentenças de discurso indireto com negação na sentença principal e quantificação existencial na sentença complemento - com esta última, em função de ocorrer como complemento, ser considerada gramatical, ainda que sozinha não - é um desafío ainda em aberto.

Um terceito problema com a solução paratática diz respeito às construções de discurso indireto em Inglês com quantificação universal e pronomes que podem ser interpretados como ligados pelo quantificador. Por exemplo, em uma leitura de

37. Every boy said that he loves chocolate.

\footnotetext{
118 J. A. H. Murray et al (eds). The Oxford English Dictionary, 253.

${ }^{119}$ Ver Schiffer (2006), em The Oxford Handbook of Philosophy of Language, parte 3, artigo 13.
} 
o pronome „he pode ser lido como ligado pelo sintagma quantificacional ,every boy paráfrase

38. $\forall \mathrm{x}: \mathrm{x}$ is a boy $\rightarrow \mathrm{x}$ said that $\mathrm{x}$ loves chocolate.

Por outro lado, quantificação universal operando para além da fronteira de duas ou mais sentenças sem vínculo de subordinação é considerado problemático em Inglês. Em

39. Every boy loves chocolate. He ate three bars of chocolete.

parece ser difícil atribuir uma leitura em que „he é uma variável presa por „every boy caso, então a explicação de Davidson fracassaria para capturar a leitura de (37) representada em (38), pois apresenta (37) como duas sentenças independentes: "Every boy said that. He loves chocolate. Isso porque em Davidson o objeto gramatical de „said é um termo referencial e não uma sentença, como recorrentemente se concebe, e cuja função é somente de se referir a um enunciado de uma sentença. Em outras palavras, a unica relação da estrutura , $\alpha$ said that ${ }^{e e}$ com uma sentença $s$ que se segue é que ,that ${ }^{e e}$ aponta um enunciado de s. Nada mais é estabelecido. Não parece haver um meio que permita quantificar sobre um constituinte do que se está apontando com ,thatee

Uma outra crítica bastante séria é levantada por Foster (1976) e Burge (1987), e envolve sentenças com discurso indireto iterado, i.e., quando „dizer que ${ }^{\text {ee }}$ toma como complemento uma sentença que já é uma sentença de discurso indireto. Esta objeção sustenta que a análise paratática não consegue acomodar tais sentenças. Considere as duas sentenças abaixo, em que a primeira foi enunciada por Carlos e a segunda por outro falante (chamemos ele de „Fernando ${ }^{c e}$ ):

40. Pedro disse que Vênus é um planeta.

41. Carlos disse que [Pedro disse que Vênus é um planeta].

(41) será verdadeira se, e somentente se, é verdadeiro que Carlos disse (40). Contudo, uma explicação paratática parece conflitar com essa inferência. Na leitura de Foster, para (41) ser verdadeira na análise de Davidson, „[Pedro disse que Vênus é um planeta] precisa ter o mesmo conteúdo do enunciado 40 (de Carlos). A objeção é que isso não ocorre porque (40) contém um demonstrativo que demonstra o enunciado de Carlos „Vênus é um planeta ${ }^{\text {ee }}$, enquando (41) contém um demonstrativo „que ${ }^{\text {ee }}$ que demonstra o enunciado de Fernando ,[Pedro disse que Vênus é um 
planeta'], e um „que dentro dos colchetes tendo por referente um enunciado distinto do demonstrado em (40). Ou seja, os demonstrativos possuem distintas referências. E, sob a suposição de que a relação de ter o mesmo significado - empregada para descrever como compreedemos o significado de „dizere em discurso indireto e elucidar a noção de ,samesaying ${ }^{\text {ee }}$ - deve preservar os referentes dos termos singulares, para „Pedro disse que Vênus é um planeta ${ }^{\text {ee }} \mathrm{e}$ „Pedro disse que Vênus é um planeta] expressarem o mesmo significado os demonstrativos „que“, de ambos teriam de ter a mesma referência. Para essa exigência valer também deve-se sustentar que a contribuição semântica de qualquer demonstrativo para o significado da sentença em que ocorre é o seu referente. À luz essas premissas, a análise paratática geraria, então, condições de verdade inadequadas para sentenças de discurso indireto com iteração do verbo „dizere.

Também tem sido argumentado que a análise paratática encontra sérias dificuldades de ser generalizada para explicar outras sentenças de atitude proposicional. A objeção repousa sobre o fato de que em muitas dessas construções pode não haver um enunciado do referente do sujeito da sentença que um enunciado do falante possa traduzir ou ,samesay ${ }^{e}$. Considere a sentença de crença

42. Pedro acredita que água é $\mathrm{H}_{2} 0$.

A dificuldade é que Pedro pode acreditar que a água é $\mathrm{H}_{2} 0$ sem jamais ter enunciado uma sentença que expresse esse conteúdo. Contudo, a solução de Davidson - tal como elaborada para o discurso indireto - apliacada à (40) requer que haja um enunciado dito ou escrito por Pedro que samesays o enuncidado ,água é $\mathrm{H}_{2} \mathrm{O}^{e}$. Embora essa crítica se aplique a uma transferência ipsis litteris da análise do discurso indireto para outras atitudes proposicionais, ela não significa uma refutação de imediato à proposta. Modificações são necessárias para acomodar sentenças com diferentes verbos psicológicos. A questão em debate é se essas alterações infrigem as linhas gerais da proposta paratática, ao ponto de se distanciarem substancialmente dela. O próprio Davidson sugere, em "Thought and Talk" ${ }^{120}$, uma paráfrase informal de sentenças do tipo (40) que, ainda que mais engenhosa, está em conformidade com seu método. Expõe Davidson:

Se afirmo „Jones acredita que a neve é branca“e, meu enunciado de ,a neve é brancae pode não ter um enunciado efetivo de Jones para imitar. Ainda assim poderíamos adotar a linha de que o que afirmo é que Jones estaria honestamente dizendo o que pensa se enunciasse uma sentença traduzindo a minha. [...] Quando digo, ,Jones acredita que a neve é brancae eu descrevo o estado mental de Jones diretamente: é na verdade o estado mental de

\footnotetext{
${ }^{120} \mathrm{O}$ conteúdo deste artigo foi primeramente apresentado na forma de uma conferência (Wolfson College Lecture, Oxford), em 1974. No ano seguindo o artigo é publicado no livro Mind and language, editado por Samuel Guttenplan, Oxford University Press. É o ensaio 11 de Inquiries into Truth and Interpretation.
} 
alguém que honestamente poderia asseverar „A neve é brança ${ }^{\text {ee }}$ se ele falasse Inglês, mas que pode ser um estado no qual uma criatura sem linguagem poderia estar (Davidson 1990 [1976]: 167).

Nos termos acima, uma paráfrase de (42) seria algo da forma:

43. Jones estaria honestamente dizendo o que pensa se fosse enunciar uma sentença samesaying meu enunciado, ,água é $\mathrm{H}_{2} 0^{\text {ee }}$

Como pode ser notado, uma tal paráfrase de sentenças de crença apresenta uma estrutura condicional em interação com tempos verbais. Além disso, atribui um estado mental ao referente do sujeito da sentença matriz, tomando este, por assim dizer, como uma disposição para enunciar e asseverar a verdade de um enunciado que samesays a ,água é $\mathrm{H}_{2} 0^{\text {ec }}$. É uma paráfrase que tem o mérito de relacionar uma crença, em criaturas portadoras de linguagem verbal, com uma disposição comportamental de produzir um dado enunciado e asseverar a sua verdade. Evidentemente que essa solução pode suscitar um debate - que extrapola o desafio de fornecer uma teoria para essas sentenças - sobre quais perspectivas de estados mentais e disposições comportamentais estariam nela embutidas ou fomentadas. Mas enquanto sugestão semântica de ampliação de uma análise paratática para sentenças de crença, ela parece se revelar, até onde consigo enxergar, uma opção viável que fortalece a proposta. Assim como ,dizer que ${ }^{e e}$,,acreditar que em (42) é analisada como estabelendo uma relação entre um enunciado do falante e um enunciado de Pedro. Com a distinção de que, no caso de ,acreditar que ${ }^{e e}$, não se requer que o enunciado do sujeito tenha sido efetivado, pois tal relação, a de ,samesaying ${ }^{e e}$, é incorporada a uma estrutural condicional, e Pedro é representado com estando num estado mental associado a uma disposição comportamental de ordem linguística. Entretanto, é fácil de perceber que as mesmas quatro objeções acima também podem ser levantadas quanto a esse tratamento paratático das sentenças de crença.

A última objeção que abordaremos é a segunda crítica de Foster ao tratamento paratático. Esta crítica decorre, principalmente, do fato de Foster interpretar a paráfrase de Davidson descrevendo o significado de ,dizer ${ }^{\text {ee }}$ como sendo parte da forma lógica das sentenças de discurso indireto. Foster tem em perspectiva, portanto, a paráfrase (34) de „dizere em construções „, disse $q^{e} e^{e}$. Orientado por essa interpretação questionável, um exame da solução davidsoniana, de acordo com o filósofo, mostra que, ainda que ela não tome sentenças em contextos opacos como "obscuramente" modificando sua referência, passando a denotar entidades como intensões, proposições, etc., ainda assim tal estratégia tende a supor um intermediário reificado entre os enunciados de uma linguagem e os fatos do mundo, um conteúdo semântico que assegura um apelo 
à noção de sinonímia sentencial. Este percurso reintroduziria, assim, tais entidades, em especial por causa da suposição de mesmo conteúdo subjacente na explicação de ,samesaying ${ }^{\text {ee }}$, que aparece na paráfrase. Foster parece nos remeter a passagens de "On Saying That" como a seguinte, em que Davidson explicitamente fala em sinonímia:

[...] o que um enuncida de „Galileo disse quee faz é anunciar outro enunciado. Como qualquer enunciado, este primeiro pode ser sério, tolo, assertivo ou divertido; mas se ele é verdadeiro, ele deve ser seguido de um enunciado sinônimo de algum outro. O segundo enunciado, o ato introduzido, pode também ser verdadeiro ou falso, ser feito de modo assertivo ou de brincadeira. Mas se é anunciado, ele deve servir ao menos ao propósito de transmitir o conteúdo do que alguém disse (Davidson [1968] 1990: 106-107).

As perguntas que se colocam são: na paráfrase do predicado „dizere, o emprego da noção de „,samesaying ${ }^{\text {ee }}$, que pressupõe uma correspondência de conteúdo, entidades intensionais não seriam indiretamente recobradas? Essa estratégia não se conformaria como um recurso de intensionalização, embora por uma manobra, por assim dizer, indireta, por meio de um deslocamento de onde é identificada a referência a entidades intensionais? Sendo essa referência não mais obra do comportamento especial apresentado pelas sentenças nesses contextos opacos, como numa solução explicitamente proposicionalista, mas reemergindo na paráfrase do comportamento de determinados verbos?

A partir dessas questões, a dificuldade que desponta, na visão de Foster, após um exame da proposta paratática, é que, mesmo que ela tenha a vantagem de evitar que "palavras usuais para planetas, pessoas, cadeiras e hipopótamos em discurso indireto possam abandonar sua referência usual pela exótica", ela parece não conseguir eliminar de todo na sua explicação o uso de um vocabulário que repousa sobre a pressuposição de significados reificados, evidenciados no conceito de samesayeing, que dependeria de noções de sinonímia, mesmo conteúdo, para fazer sentido.

Davidson, ciente de que um exame do percurso da sua explicação suscitaria a crítica acima, já antecipa, em "On Saying That", uma argumentação:

Tentamos apresentar o sabor da nossa análise [...] renomeando nossa sentença favorita como "Galileo enunciou uma sentença que significou em sua boca o que "A terra se move" significa na minhae. Não devemos pensar mal dessa versão prolixa de „Galileo disse que a terra se move "er causa da aparente referência a um significado ("o que „A Terra se move significa"); essa expressão não é tratada como um termo singular na teoria. Somos convidados a dar sentido a um julgamento de sinonímia entre enunciados, não como a fundação de uma teoria da linguagem, mas como meramente uma parte não analisada do conteúdo do vocabulário familiar do discurso indireto. A ideia subjacente a nossa paráfrase desajeitada é a de samesaying: quando digo que Galileo disse que a Terra se move, represento Galileo e eu como samesayers (Davidson [1968] 1990: 104). 
Notem que esta passagem não só aponta para esta crítica provável, mas também, para a interpretação do método que subjaz à crítica: de que as paráfrases elaboradas no texto são a forma lógica proposta para essas sentenças, e que, por conseguinte, elas serão exibidas nas suas sentenças$\mathrm{T}$ numa teoria da verdade. Mas essa leitura da proposta é equivocada. E a resposta de Davidson à objeção se centra, por isso, nesta premissa.

$\mathrm{Na}$ abordagem de Davidson, numa teoria da verdade „dizere é tratado como um termo primitivo que deve receber uma cláusula de satisfação especificando sua contribuição na geração de sentenças-T. A paráfrase informal das sentenças do tipo , $\alpha$ disse que ${ }^{e e}$, indicando que um enunciado de $\alpha$ partilha o mesmo conteúdo do que o pronome ,que demonstra, tem o propósito de ajudar a explicar o significado do verbo, e não é parte da teoria composicional. O erro repousa em tomar esta paráfrase heurística, como uma proposta de forma lógica:

Foster erradamente diz que minha análise de Galileo disse que é ,algum enunciado de Galileo e meu último enunciado torna Galileo e eu same-sayers"e. Isso não é uma análise, mas um uma modo de refrasear desenhado para dar ao leitor uma sensação da semântica; um mecanismo expositivo e heurístico (Davidson [1976] 1990: 176-7).

Mas alguém poderia objetar: “numa proposta como esta a sentença-T fornecida para „Galileo disse que a Terra se move ee não será suficiente, sozinha, para exibir o significado da sentença. Posto em outros termos, alguém que só tem acesso ao que é exibido na sentença-T de s, onde s é uma sentença de discurso indireto, não será capaz de compreender s. Logo, o método não cumpriria o que se propõe". Entretando, Davidson não sustenta que cada sentença-T, e os axiomas de satisfação das expressões subsentenciais, precisam fornecer tudo o que é necessário para compreeder as sentenças de uma linguagem objeto. $\mathrm{O}$ que os axiomas e as sentenças-T devem exibir é o aspecto composicional dos termos que precisamos saber para determinar a verdade das sentenças em relação aos contextos de uso. Há elementos dos significados dos termos que não são capturados recorrendo somente a uma semântica composicional de condições de verdade. As sentenças-T não precisam exibir todos os recursos necessários para a interpretação Por exemplo, suponhamos que a paráfrase para explicar o significado de ,,dizeree seja incorporada a uma semântica lexical para esses tipos de verbo. Neste caso, a conjunção das sentenças- $T$ de „Galileo disse que ${ }^{\text {e }}$ „,A Terra se move em uma teoria- $T^{*}$, acompanhada de uma teoria lexical dos verbos de discurso indireto, conformaria um quadro que nos apresenta mais recursos para a compreensão dessa classe de sentenças, mostrando que uma teoria-T, por si só, não é suficiente.

Uma última observação para concluir esta seção. Abordaremos, no capítulo $\mathrm{V}$, a relação entre teoria da verdade e conhecimento da teoria, com enfoque no problema acerca do que é necessário e suficiente saber sobre uma teoria da verdade para assegurar sua interpretatividade e 
usá-la como veículo de uma teoria do significado, assim como as implicações disso para a viabilidade da semântica davidsoniana. Esse é o tema nuclear do debate entre Davidson e Foster. A crítica de Foster à proposta paratática é um componente deste debate. E uma vez que a questão do emprego dos conceitos intensionais de ,mesmo conteúdo/significado ${ }^{e e}$, „sinonímia ${ }^{\text {ee }}$,traduçãoe, e a sombra de reificação que eles lançam abarca todo o projeto, não sendo uma questão local, ou seja, apenas suscitada na análise de construções opacas, uma apreciação mais conclusiva deste desafio, assim se espera, ocorrerá no capítulo que se segue.

\section{Considerações finais.}

Neste capítulo, examinamos a proposta pararática de Davidson para sentenças de discurso indireto, construções opacas que, como outras com verbos psicológicos (,acreditare, „sabere, „duvidare, etc), são de difícil incorporação em uma semântica sistemática do tipo proposta pelo filósofo. A fim de dimencionar a originalidade desta proposta, situou-se ela no contexto de algumas das principais investigações, debates, e análises dessa classe de sentenças na filosofia da linguagem, em especial as teses de interlocutores explícitos de Davidson. De um lado, abordagens proposicionalistas, inauguradas pela análise fregeana, cujo exponte destacado é Alonzo Church. Por outro lado, propostas ditas sentencialistas, que intentam evitar uma referência explícita a proposições, optando por objetos alternativos, tais como sentenças e enunciados, como as de Carnap e Quine. Examinouse as vantagens e limites de tais métodos, concluíndo com uma investigação dos detalhes técnicos da alternativa paratática, e aspectos inconclusives da análise. Esperou-se com essa organização das etapos do capítulo, destacar o aspecto desafiador do tema, assim como mostrar que ele continua um

problema em aberto, terreno no qual o que menos se deve esperar são soluções imunes a consequências e dilemas que limitam o escopo de suas aplicações. Em alguns casos, demonstrou-se que até mesmo a própria existência de algumas propostas é ameaçada. 


\section{CAPÍTULO V: O PAPEL DE UMA TEORIA DA VERDADE NO CORPO DE UMA TEORIA DO SIGNIFICADO.}

\section{Introdução.}

Uma teoria interpretativa da verdade para uma língua L consiste, como desenvolvido nos capítulos precedentes, em uma teoria composicional que contém os recursos para gerar, para cada sentença de $\mathrm{L}$, um teorema-T da forma ,s é verdadeira em $\mathrm{L} \leftrightarrow p^{\mathrm{ee}}$, onde , , é substituída por uma descrição metalinguística de uma sentença de $\mathrm{L}$, e ,p por uma sentença que traduz a sentença especificada do lado esquerdo do bicondicional. Contudo, é bastante perceptível que uma teoria-T interpretativa, i.e., que acarreta somente teoremas-T interpretativos, não diz por si que ela é interpretativa. É possível conceber para cada teoria interpretativa para uma língua outras que não o são. O problema que isso coloca é que saber uma dada teoria-T interpretativa para uma língua L não é suficiente para nos dizer se ela é interpretativa ou não.

Em outros termos, posso ter o conhecimento dos fatos que uma teoria-T interpretativa para L expressam e ainda assim não saber o que as sentenças de L significam. Dessa constatação derivam dois desafios cruciais para os quais Davidson intenta fornecer respostas: (i) elaborar um conjunto de restrições que assegurem que uma teoria-T seja interpretativa, ou seja, que permitam a construção de uma teoria-T aceitável; e (ii) propor o que é suficiente e necessário que um teórico saiba acerca de uma teria-T para usá-la para interpretar um língua. Considero que um exame adequado dessas duas questões perceptivelmente complementares, que lançam luz sobre a relação entre uma teoria-T e o conhecimento dela, é fundamental para elucidar o papel que uma teoria da verdade desempenha em uma teoria do significado tal como concebida por Davidson. Investigando as soluções que Davidson contempla para esses desafios, espero cumprir duas tarefas neste último capítulo. Em primeiro lugar, argumentarei, em consonância com Lepore \& Ludwig (2005), que a objeção de Foster (1976) - segundo a qual qualquer descrição do conhecimento acerca de uma teoria da verdade que garante o seu emprego na interpretação extrapolaria as próprias condições impostas por Davidson, demonstrando, com isso, que elas se revelam insuficientes para o sucesso do projeto - resulta de uma leitura equivocada da visão de Davidson. Espero mostrar que as condições a mais que o próprio Foster propõe introduzir, não somente não são incompatíveis com as de Davidson, mas na verdade por ele também contempladas. Em segundo lugar, olharei para como Lepore \& Ludwig $(2005 ; 2007)$ identificam uma teoria do significado com um corpo de conhecimento apropriado sobre uma teoria interpretativa da verdade. Segundo os autores, esse conhecimento pode ser explicitado independentemente da ambição filosófica mais geral do projeto de Davidson de traçar uma relação entre os conceitos semânticos de sinonímia, tradução, mesmo 
conteúdo empregados na teoria, e noções mais básicas - como disposições para reagir a enunciados de sentenças em situações determinadas - via um método que mostre que aqueles conceitos podem ser empiricamente aplicados com base em evidências que forneçam motivações suficientes para se interpretar um falante sem apelar de antemão a eles. Davidson intenta elaborar este método de confirmação e o chama de intérprete radical. Para ele, em última instância, o sucesso do seu projeto depende da viabilidade de se confirmar, do ponto do vista do intérprete radical, se uma teoria-T é interpretativa. Independentemente de se as restrições sobre as evidências propostas para a interpretação são suficientes para garantir um emprego das noções de tradução, sinonímia, etc., sem incorrer em reificações, parece-me que o sucesso da viabilidade de uma teoria do significado deste tipo depende, para Davidson, do intérprete radical demonstrar esta possibilidade. Mas é exatamente neste aspecto importantíssimo do projeto que Lepore \& Ludwig parecem se distanciar de Davidson, pois acreditam que uma teoria do significado pode ser empreendida independentemente do procedimento do intérprete radical ou de qualquer outro concebível método com o mesmo propósito, sem que isso fira as ambições essenciais projeto.

Contudo, entendo que tal estratégia, por dispensar um método que ilumine como que podemos empregar expressões do lado direito das sentenças- $\mathrm{T}$ que podem ser consideradas interpretações, traduções, das sentenças descritas do lado esquerdo, apenas assume, de antemão, que o que ocorre do lado direito é uma tradução correta. E como uma teoria que apenas toma como pressupostas essas noções semânticas ilumina muito pouco o significado das sentenças, a ausência de um método de se chegar ao conteúdo informacional das expressões de uma língua L parece aproximar mais a semântica de Lepore e Ludwig da postura de Tarski, que, como sabemos, toma como pressupostas as noções de tradução e sinonímia, de maneira a construir uma definição de verdade para uma linguagem, do que da estratégia de Davidson, que consiste na tentativa de empregar uma teoria de tipo tarskiana para iluminar o papel que aqueles conceitos semânticos desempenham na teoria do significado, e de como são úteis para a análise semântica com valor empírico. Por fim, espero mostrar que, por conta desta cisão entre uma suposta semântica formal propriamente dita e um método do tipo do intérprete radical, exatamente no ponto em que se intenta especificar a conexão entre uma teoria interpretativa da verdade e uma teoria do significado, chamadas pelos autores de teoria explícita do significado - uma espécie de lista do que alguém deve saber sobre uma teoria interpretativa da verdade que o permite inferir, de cada sentença-T, i.e., instanciações do esquema 's é verdadeira se, somente se $p$ ', o teorema ' $s$ significa $p$ ' - não estou totalmente convencido de que uma reificação não seja necessária. Na teoria explícita dos autores, é estabelecida, entre outras condições, que não é suficiente saber o conteúdo informacional expresso pelos axiomas de uma teoria da verdade, mas saber quais conteúdos os axiomas expressam. Isto é, 
tem-se que saber o que os axiomas significam, associar o conteúdo adequada a cada axioma. O que me parece é que para detalhar na forma de uma teoria explícita esse conhecimento faz-se necessário quantificar sobre estes conteúdos semânticos. Logo, se meu raciocínio estiver correto, como espero elucidar, uma teoria do significado como proposta por Lepore \& Ludwig não seria imune a uma quantificação sobre significados, e, por conseguinte, a uma reificação. Enfim, essa é a constelação de questões que intento explorar nas seções que se seguem.

\section{Algumas estratégias para barrar teorias-T não interpretativas.}

Meramente demandar de uma teoria-T que todas as suas sentenças-T sejam extensionalmente adequados, i.e., que as estruturas bicondicionais que expressam sejam verdadeiras, não garante, presumivelmente, que ela seja interpretativa. Tal constatação é chamada algumas vezes de $o$ problema da extensionalidade. Para ilustrar isso é simples. Suponha que nossa linguagem objeto seja o Inglês, e a metalinguagem seja o Português. Considerem agora as duas sentenças-T abaixo:

1. 'Snow is white' é verdadeira em Inglês $\leftrightarrow$ a neve é branca.

2. 'Snow is white' é verdadeira em Inglês $\leftrightarrow$ a Terra é um planeta.

Se julgarmos nossa teoria-T somente pelo critério da verdade de suas sentenças- $T$, ou seja, se as sentenças nomeadas no lado esquerdo e as sentenças usadas no lado direito possuem o mesmo valor de verdade - que é a única conexão exigida pelo bicondicional - então, sendo (1) e (2) verdadeiras, ambas constariam como instanciações verdadeiras do esquema-T.

Mas que tipo de teoria-T poderia ser empregada para interpretar fragmentos de uma língua? Recordemos que Davidson concebe uma teoria do significado para uma língua L como uma teoria que, uma vez conhecida, permite, a quem quer que a possua, interpretar as sentenças de L. De partida, Davidson entende que uma teoria-T de tipo tarskiana possui algumas das propriedades requeridas: ela é construída como uma teoria formal finita, com axiomas de satisfação que especificam para cada expressão subsentencial propriedades semânticas com base nas quais são derivados teoremas-T.. Somado a isso, os axiomas de satisfação e os teoremas podem emparelhar expressões/sentenças da linguagem objeto com expressões/sentenças da metalinguagem que podem ser usadas para especificar seus significados. Para isso é preciso que essas expressões/sentenças da metalinguagem sejam traduções das expressões/sentenças da linguagem objeto. Entretanto, certas teorias-T justamente não têm a propriedade que uma teoria do significado deve apresentar: elas não informam sobre os sentidos das expressões. Recordem que, para Tarski, um elemento crucial para que uma teoria-T satisfaça a sua Convenção-T é que ela forneça do lado direito das sentenças-T 
traduções das sentenças da linguagem objeto. Como o propósito de Tarki era o de definir verdade para uma linguagem, ele toma a noção de tradução como dada, e a emprega na construção da sua definição de verdade, como já explicitada mais de uma vez no curso da tese. Em contrapartida, o projeto de Davidson consiste, digamos, numa inversão do horizonte de Tarski: partir de uma teoria da verdade e do maquinário formal que ela disponibiliza, para intentar lançar luz sobre o significado das sentenças de uma língua, e os conceitos semânticos intensionais vinculados de tradução, sinonímia, interpretação.

Dado que as informações fornecidas por uma teoria-T estão aquém do que é requerido para empregá-la para interpretar, ao ponto de que, mesmo que ela seja interpretativa, ela, por si, não diz que possui esta propriedade, Davidson precisa propor condições e restrições sobre a forma de uma teoria-T que permitam eliminar sentenças-T como (2). O desafio que Davidson se coloca, contudo, é grande, uma vez que ele, de antemão, não se permite dizer o que é necessário para que uma teoria da verdade seja interpretativa usando as noções semânticas mencionadas acima. O percurso a construir é conformar um conjunto $\mathrm{C}$ de restrições e condições que, se satisfeitas, garantem a verdade do seguinte enunciado: se uma teoria-T para L cumpre C, então, para todo 's é verdadeiro p'de T, 's significa (que) p'. Olhemos, então, para as restrições/condicões exibidas por Davidson.

Aqui Davidson sugere uma primeira solução, sem ainda pontuar a vantagem de uma teoria composicional em relação a uma teoria que seja uma mera lista de sentenças-T, como a que supomos acima. Dado que uma teoria-T para uma língua natural tem de ser uma teoria empírica, os seus teoremas devem ter a foma de leis (lawlikes), e, por isso, amparar construções contrafactuais (support counterfactuals). Disso resultaria o contraste entre a versão contrafactual de (1), que parece ser verdadeira, e a de (2), que parece ser falsa.

1'. 'Snow is white' não seria verdadeira em Inglês se a neve não fosse branca.

2'. 'Snow is white' não seria verdadeira em Inglês se a Terra não fosse um planeta.

Ainda que Davidson não se prolongue sobre esta proposta, o seu propósito ao aventá-la é claro: o contraste identificado entre (1') e (2') testemunharia em favor de (1), pelo fato de indicar que (1) é menos acidentalmente verdadeira do que (2) ${ }^{121}$. Mas esse percurso não se revela de todo seguro, como nos chama a atenção Gabriel Segal (2000) com um caso interessante. Suponha que seja uma lei que a condutividade elétrica e a térmica covariam nos metais, o enunciado científico (3) abaixo ampara uma construção contrafactual:

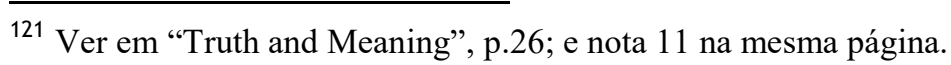


3. 'Cobre conduz calor' é verdadeira em Português $\leftrightarrow$ cobre conduz eletricidade.

Mas a feição de lei de (3) aparenta não ser suficiente para assegurar (3) como uma sentença-T interpretativa (no sentido de 'cobre conduz eletricidade' ser uma tradução da sentença descrida no lado direito da implicação material). Ou seja, as propriedades de conduzir calor e eletricidade, ainda que coextensivas, não seriam sinônimas. Do que se conclui que, se (3) não é o teorema adequado de uma teoria-T que se quer construir, então a tese de que uma teoria- $\mathrm{T}$ deve fornecer somente teoremas para as sentenças de uma linguagem que operam na forma de uma lei não é suficiente para que ela seja interpretativa, ainda que reduza o número das teorias que não o são ${ }^{122}$.

Mas é importante recobrar aqui o requerimento da composicionalidade, cuja demanda essencial é que as sentenças-T de uma teoria-T não sejam uma mera lista, mas geradas de forma composicional e sistemática a partir dos axiomas de satisfação construídos para as expressões linguísticas que formam as sentenças da linguagem objeto. Em uma teoria composicional, (1) será gerada com base em regras de composição, um axioma de satisfação para 'snow' e uma para 'be white'. Axiomas esses que seriam distintos dos oferecidos para 'Earth', e 'be a planet'. Esse procedimento certificaria que uma teoria composicional produzisse (1) e bloqueasse (2), sugere Davidson. Contudo, é possível ainda conceber uma teoria composicional em que os axiomas para os predicados de uma linguagem sejam (i) extensionalmente adequados e (ii) contenham expressões que podem ser consideradas como sinônimas dos predicados (ainda que não só elas), e ainda assim não são suficientes para que a a teoria-T seja rigorosamente interpretativa.

Axiomas para os predicados também podem dificultar a determinação de teorias interpretativas. Considerem os axiomas abaixo de uma teoria-T’ para uma língua L':

AX1: Ref('Paulo’) = paulo

AX2: Para todo nome $\alpha$, ' $\alpha$ é atleta' é verdadeira em L' $\leftrightarrow \operatorname{Ref}(\alpha)$ é atleta

Podemos gerar, via teoria-T', a seguinte sentença-T:

4. „Paulo é atleta é verdadeira em $L^{c e} \leftrightarrow$ paulo é atleta.

\footnotetext{
${ }^{122} \mathrm{O}$ exemplo que Segal mobiliza para o seu argumento é equivocado, como bem observou o professor Roberto Horário, na arguição de defesa da tese. Existem condutores de eletricidade frios, os chamados supercondutores. Todavia isso não compromete o espírito do argumento - que é de mostrar que leis não discriminam predicados coextensivos não sinônimos - se encontrarmos um exemplo nomológico apropriado. Os predicados triangular e trilátero cumprem este papel, pois, ainda que sejam coextensivos, diferem em sentidos.
} 
Mas substituamos o axioma interpretativo AX2 por

AX2 2 : Para todo nome $\alpha$, ,, $\alpha$ é atleta é verdadeira em $L^{\text {ee }} \leftrightarrow \operatorname{Ref}(\alpha)$ é atleta e todo animal é um animal.

onde uma tautologia é introduzida do lado direito da implicação mediante conjunção. Neste caso, nossa teoria, com esta modificação - chamemos ela de teoria-T"' - deriva a sentença-T

5. „Paulo é atleta é verdadeira em $\mathrm{L}^{\complement e} \leftrightarrow$ paulo é atleta e todo animal é um animal.

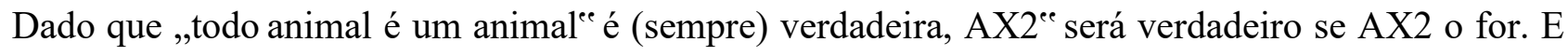
ambos os axiomas são extensionalmente adequados, ou seja, as sentenças mencionadas (do lado esquerdo) e usadas (do lado direito) possuem os mesmo valores de verdade. O resultado é que o problema da interpretatividade parece emergir mesmo para uma teoria-T composicional, porque é possível conceber uma sentença-T como (5), que não é sinônima de (4), gerada com a contribuição de um predicado como $\mathrm{AX}^{\text {ee }}$, em que de forma ad hoc uma tautologia é adicionada. Logo, axiomas extensionalmente adequados não são suficientes para salvaguardar um procedimento de derivação em que se possam determinar quais as sentenças-T resultantes são interpretativas. Frequentemente este impasse é chamado de problema da determinação. Sempre estaria a nossa disposição o recurso de adição de uma tautologia em alguma etapa da prova, cujo resultado final será ,s é verdadeira $\leftrightarrow$ $p$ e TL"e, onde TL é qualquer tautologia.

Os problemas ilustrados acima emergem porque Davidson busca, primeiramente, formular restrições para um predicado de verdade para uma língua sem uma invocação direta das noções semânticas de sinonímia e tradução. Para Davidson, não basta simplesmente demandar que os axiomas da teoria sejam interpretativos, que forneçam traduções do lado direito do bicondicional. Esse não é o ponto de partido pressuposto. É para Davidson o ponto a se chegar. Ou seja, o objetivo é examente, como dito, tentar iluminar esses conceitos, impondo, por um lado, um conjunto de restrições sobre a forma de uma teoria-T, sem usar noções além das de verdade, referência e satisfação, e, por outro, empregando o método do intérprete radical, desenhado como um procedimento de confirmação de que uma teoria-T pode ser utilizada para interpretar uma língua. A ambição é de que a viabilidade empírica das noções intensionais, independentemente da ausência de definições rigorosas para elas, possa ser justificada por meio do fornecimento de um método que exiba o que poderíamos saber que nos capacitasse a interpretar um falante sem apelar de início a 
esses mesmos conceitos. ${ }^{123}$ Voltaremos à questão do estatuto do método do intérprete radical no projeto semântico de Davidson na última seção deste capítulo, quando confrontaremos nossa interpretação do projeto com o encaminhamento que entendemos que Lepore \& Ludwig deu a ele, os quais propõem uma separação entre um suposto projeto inicial, e um subsequente projeto estendido, no qual aí sim o procedimento do intérprete radical seria central.

Com o propósito de impor, então, restrições que excluam axiomas do tipo $\mathrm{AX} 2^{\text {ee }}$ e teoremas como (5), Davidson recorre a considerações que em geral regulam a construção e adoção de uma teoria empírica, a saber, os princípios da economia e simplicidade. Em conexão com os casos acima, por exemplo, comparando as sentenças-T que derivam da teoria- $T^{\text {ee }}$ (que contém o axioma AX2), com as da teoria- $T^{\text {eee }}$ (que apresenta também axioma AX2"), percebe-se que o lado direito de algumas sentenças- $\mathrm{T}$ da teoria- $\mathrm{T}^{\text {eeee }}$ inplica o lado direito das sentenças- $\mathrm{T}$ correspondentes da teoria$T^{e e}$, mas não o inverso. Se a única disntinção entre ambas as teorias residir em tais casos, isso pode ser uma razão suficiente pela preferência pela teoria que apresenta os axiomas estruturalmente mais simples. Sob a constatação de que a teoria- $T^{\text {eece }}$, em relação à teoria- $T^{e e}$, apresenta uma complexidade estrutural desnecessária, uma vez que atribui estruturas superfluas a certas sentenças da linguagem objeto mediante o axioma AX2 $2^{\text {ee }}$, seria justificável descartar a teoria- $T^{\text {eece }}$.

$\mathrm{O}$ apelo aos princípios da economia e simplicidade é motivado pelo fato de que uma teoria-T que emprega somente um aparato lógico simples - no nosso caso, a lógica de predicados de primeira ordem com identidade - revela-se, na ausência de qualquer outra restrição, sobreprodutiva. Isso porque não há como evitar que estruturas redundantes, como tautologias, sejam inseridas aleatoriamente em qualquer etapa da derivação. Entretando, uma dificuldade parece permanecer. Os princípios mencionados, embora permitam optar por uma teoria que gera (4), não bloqueiam a derivação de (5). Por isso, alguns semanticistas entendem que é fundamental fornecer um método de derivar, com base apenas em considerações de ordem formal, sentenças-T em que a introdução de tautologias seja bloqueada. Essa abordagem requer a especificação de um procedimento de prova, chamado muitas vezes de procedimento canônico, que garanta que somente sejam gerados

\footnotetext{
${ }^{123}$ Em "Radical Interpretation" há uma passagem elucidativa em que Davidson contrasta a sua metodologia do intéprete radical como forma de iluminar esses conceitos intensionais com o percurso predominante de buscar definições dos mesmos de maneira a justificar sua aplicabilidade: "Em filosofia estamos familizarizados com definições, análises e reduções. Tipicamente, com elas intenta-se nos conduzir de conceitos melhor compreendidos, ou mais claros, epistemologica ou ontologicamente mais básicos, a outros que queremos compreender. O método que sugeri não se encaixa em nenhuma dessas categorias. Eu proponho uma relação mais frouxa entre conceitos a serem iluminados e os relativamente mais básicos. No centro está uma teoria formal, uma teoria da verdade, que impõe uma estrutura complexa às sentenças e que contém as noções primitivas de verdade e satisfação. A essas noções são dadas aplicações pela forma da teoria e a natureza da evidência. O resultado é uma teoria parcialmente interpretada. A vantagem do método está não no seu apelo livre à noção de base evidencial, mas na ideia de uma teoria poderosa interpretada do ponto mais vantagoso. Isso nos permite reconciliar a necessidade de uma estrutura semanticamente articulada com uma teoria testável somente no nível sentencial" (Davidson 1999 [1973]: 137).
} 
teoremas interpretativos. O problema, então, não é só determinar qual sentença-T é interpretativa, mas de impedir, via regras de derivação, a produção de sentenças-T não interpretativas. A viabilidade de se fornecer um procedimento assim é central para aqueles que acreditam que para o sucesso da teoria não basta apenas identificar a derivação, por exemplo, na qual uma tautologia foi de forma espúria inserida, mas de não permitir, em cada etapa da prova, que essa introdução seja possível. Basicamente, o intuito é de determinar que as únicas sentenças que podem entrar na prova sem serem derivadas de outras sentenças são os axiomas. Ou seja, o desafio é de restringir a lógica empregada pela teoria de maneira a só gerar sentenças-T interpretativas, sem adição de tautologias. Posto de outra forma, procura-se, com isso, derivar os teoremas somente com base no conteúdo dos axiomas; uma sentença-T assim derivada, espera-se, forneceria as condições de verdade para a sentença da linguagem objeto que interpreta, uma vez que do lado direito teríamos uma tradução da sentença. O papel das regras a serem construídas é, portanto, delimitar as inferências permissíveis na derivação, barrando o aparecimento de conteúdos gratuitos em qualquer fase da derivação. Se isso for atingido, o que se teria é a capacidade de determinar as provas que se assentam somente nos axiomas interpretativos e nas regras de inferência fornecidas, ou seja, de dizer não apenas quais sentenças-T são interpretativas, mas que elas são também derivadas mediante uma prova canônica. Uma teoria-T envolveria, desse modo, uma lógica e um conjunto de regras de derivação que somente operam sobre axiomas interpretativos.

Há na literatura duas propostas detalhadas de um método de prova canônica. A estratégia de Larson \& Segal está em Knowledge of Meaning (1997), que consiste numa proposta de incorporar uma semântica inspirada em Davidson a uma abordagem cognitivista, nos marcos do paradígma gerativista. Uma segunda proposta é apresentada por Lepore \& Ludwig em Donald Davidson's Truth-Theoretic Semantics (2007), trabalho ao qual já nos referimos muitas vezes, pela sua importância, ao longo da tese. ${ }^{124}$ Afora as especificidades de cada método, e as diferenças que entre eles existam, cumbre destacar que uma condição colocada por ambos é que os axiomas sejam interpretativos. As regras de inferências que garantirão a derivação somente de sentenças-T interpretativas operarão sobre esses axiomas que, de partida, são tomados como interpretativos, i.e., os termos na metalinguagem enpregados no lado direito dos axiomas fornecem traduções dos termos da linguagem objeto que estão do lado esquerdo. Notem então que uma prova canônica quer impedir a introdução de conteúdos aleatórios no percurso da prova, mas, presumivelmente, não tem o poder de participar na determinação de quais axiomas são interpretativos. As regras de inferência operam nos dois métodos, como esperado, como um recurso técnico que especifica sintaticamente

\footnotetext{
${ }^{124}$ Para uma exposição pormenorizada do método de prova canônica de Lepore \& Ludwig, ver Lepore \& Ludwig (2010 [2007]: 36-37).
} 
as provas canônicas, com base na assunção prévia de que o teórico que emprega essas regras para fornecer sentenças-T interpretativas para os fragmentos de uma língua sabe que os axiomas são interpretativos. Essa estratégia, no entanto, difere do caminho traçado por Davidson. Lepore \& Ludwig claramente reconhecem isso, e sublinham que "o apelo à restrição que os axiomas sejam interpretativos viola a restrição de que devemos dizer o que é necessário [para a interpretatividade] sem o apelo a noções semânticas"(Lepore \& Ludwing 2010 [2005]: 109). A estratégia de Davidson, como já demos indicação neste capítulo e esperamos detalhar mais à frente, desenvolvida nos escritos sobre o método do intérprete radical, não é de prescrever de partida que os axiomas sejam interpretativos, pois fazer isso não é senão pressupor que os axiomas fornecerão traduções, mas mudar a rota, e tentar apresentar um método por meio do qual, uma vez em posse de uma teoria-T extensionalmente adequada, possa ser dito o que é suficiente para que justamente essa teoria-T seja também interpretativa. Independentemente de se o método do intérprete radical consegue ou não cumprir essa tarefa nada simples somente com as condições que Davidson fornece (problema sobre o qual há uma considerável literatura, e que dada a sua complexidade exigiria outra tese), é fato que tentar fornecer uma teoria composicional do significado para uma língua via (i) uma caracterização de um método de prova canônica para uma teoria-T, e (ii) a estipulação prévia de que os axiomas sejam interpretativos, de maneira que saber (i-ii), e saber que se sabe (i-ii), é tudo que o que é preciso para empregar uma teoria-T para interpretar, não é o percurso escolhido por Davidson. $\mathrm{O}$ método do intérprete radical, motivado pela ambição de que a interpretatividade de uma teoria-T pode ser verificada sem adotar (ii), é parte constitutiva e definidora do que consiste uma teoria composicional do significado para Davidson. Do que se segue - se minha leitura estiver correta que a ideia de que uma semântica que cumpre, nas suas linhas fundamentais, o que Davidson espera que ela realize, pode, permanecendo no espírito davidsoniano, ser empreendida tendo (ii) como premissa, é bastante questionável. Mas há ainda uma outra consequência, que sendo comprovada, revela-se ainda mais prejudicial para uma postura que não vê problema numa cisão entre projeto de uma teoria composicional do significado de inspiração davidsoniana e o procedimento do intérprete radical. Como veremos em detalhe, suspeito que, em especial na teoria explícita do significado de Lepore \& Ludwig, que consiste numa lista que abarca justamente o conhecimento de (i-ii), bem como generalizações sobre essas condições, o fantasma da reificação reaparece em relação ao conteúdo semântico expresso pelos axiomas. Antes de me deter a esta questão ainda é preciso, contudo, passar pelo debate entre Davidson e Foster sobre o problema do que consiste o conhecimento suficiente e necessário acerca de uma teoria da verdade, e se os termos em que esse conhecimento é exibido conflitariam com as ambições extensionalistas do projeto de Davidson, sobretudo tal como ele estaria exposto em "Truth and Meaning”. Uma avaliação do conteúdo da 
seção que se segue será importantísssimo para uma apreciação justa do problema que entendo ser suscitado por teorias do tipo das que Lepore \& Ludwig fornecem, e que podem as afastar de uma semântica ipso facto davidsoniana.

\section{Conhecimento sobre uma teoria-T.}

Nesta seção me concentrarei na crítica de Foster, que talvez seja a mais mencionada a respeito do projeto de Davidson, e não poucas vezes vista como uma objeção intransponível ao emprego de uma teoria da verdade na construção de uma teoria do significado, rigorosamente como a que Davidson prescreve. A partir dela, e pontuando os equívocos de interpretação que, suspeito, em parte a originam, intento elucidar no que consiste para Davidson o conhecimento acerca de uma teoria da verdade, e quais são de fato as restrições que ele estipula para esse conhecimento.

A objeção de Foster, também elaborada no artigo de 1976, dividi-se em dois momentos coordenados. No primeiro, ele sustenta que as afirmações de Davidson, em particular em "Truth and Meaning”, sobre o que seria suficiente saber para ser capaz de usar uma teoria-T para interpretar as sentenças de uma língua são insatisfatórias, e requerem, por essa razão, uma nova formulação. Entretanto, e aqui entra a segunda etapa da crítica, o que seria necessário acrescentar nesta reformulação conflitaria com as restrições que o próprio Davidson impõe, de maneira que um projeto semântico que explicite o que seria suficiente saber acerca de uma teoria-T somente teria sucesso extrapolando as fronteiras que demarcam um projeto de tipo davidsoniano: somente violando premissas nucleares do projeto.

Segundo Foster, Davidson sustentaria a posição de que saber que uma teoria-T é uma teria da verdade para uma língua L, e saber os fatos (conteúdos) que a teoria expressa, seriam suficientes para saber L. Foster demonstra a inadequação de tal tese. O argumento é de que alguém pode saber que uma teoria-T é uma teoria da verdade para $\mathrm{L}$, e saber os fatos que $\mathrm{T}$ expressa, e ainda assim não saber que a teoria expressa tais fatos. Não é difícil de dizer como isso se daria. Por uma questão de ilustração assumamos que os fatos expressos pela teoria sejam proposições. Podemos estar na situação de saber que uma teoria da verdade - um objeto sintático formado de sentenças que são seus axiomas, mais regras de inferência - é desenhada como uma teoria para L, e também saber as proposições expressas pelos seus axiomas, mas mesmo assim não saber que os axiomas expressam essas proposições. É concebível uma situação na qual não se sabe que os axiomas da teoria expressam qualquer conteúdo que por ventura já sabemos, quer identifiquemos os seus axiomas ou não. Em tal caso, tem-se o conhecimento das proposições que eles expressam de forma independente, sem que se possa relacioná-las aos axiomas. 
Sigamos, então, Foster na confecção de contextos em que isso ocorreria. Suponha que $\Phi$ é uma formulação exata em Português de tudo o que uma teoria da verdade $\mathrm{T}^{*}$ expressa. Imagine que Paulo, um falante nativo monolíngue de Português que desconhece completamente o Guarani, aceita $\Phi$ com base na autoridade de Sandra, uma renomada linguista, sua vizinha e especialista em Guarani. Sandra, entretanto, não informa Paulo de que $\Phi$ é uma teoria da verdade em Português para $\mathrm{L}_{\mathrm{g}}$ (um fragmento do Guarani). Assim posto, embora Paulo saiba todas as proposições que $\Phi$ expressa, e ainda que sejam as mesmas proposições expressas por T*, a teoria da verdade "oficial" para $\mathrm{L}_{\mathrm{g}}$, ele não pode usar esse conhecimento para interpretar $\mathrm{L}_{\mathrm{g}}$, porque desconhece qual teoria expressa estas mesmas proposições. Agora, dando um passo a mais, suponha que Sandra, confiante na capacidade linguística de seu vizinho, exiba para Paulo $T^{*}$, especifique suas regras de inferência, e informe para ele que a sentenças de $\mathrm{T}^{*}$, que estão em Inglês, em conjunção com essas regras, conformam uma teoria da verdade para $\mathrm{L}_{\mathrm{g}}$. Por fim, fornece um critério por meio do qual Paulo possa, com base nos axiomas e regras de inferência identificar as sentenças- $\mathrm{T}$ de $\mathrm{T}^{*}$. Informado desta forma, Paulo não somente saberia que $\mathrm{T}^{*}$ é uma teoria da verdade para $\mathrm{L}_{\mathrm{g}}$, mas seria capaz de, mediante a derivação mecânica de sentenças-T, fornecer traduções em Inglês de qualquer sentença de $\mathrm{L}_{\mathrm{g}}$. Neste segundo caso, Paulo estaria em posse das duas condições que Foster atribui a Davidson: ele sabe as proposições expressas por $\mathrm{T}^{*}$ e sabe que $\mathrm{T}^{*}$ é uma teoria da verdade para $\mathrm{L}_{\mathrm{g}}$. No entanto, uma vez que Paulo não sabe Inglês, e desconhece que $\Phi$ e $T^{*}$ expressam as mesmas proposições, ele não pode converter o seu conhecimento em uma interpretação de $\mathrm{L}_{\mathrm{g}}$. Nesse sentido, esses exemplos mostram que nosso conhecimento de que $\mathrm{T}^{*}$ é uma teoria da verdade pode não ter relação direta com nosso conhecimento dos fatos que $\mathrm{T}^{*}$ expressa. A lição a se tirar disso, conclui Foster, é que saber as proposições expressas por uma teoria não é equivalente a saber quais são os axiomas da teoria e o que eles veiculam (significam). Para usar uma teoria da verdade para interpretar uma língua, por conseguinte, é preciso saber não somente os fatos que a teoria expressa, mas também que a teoria expressa esses fatos. Ou seja, tem-se que saber as proposições que os axiomas da teoria veiculam e qual axioma expressa qual proposição. Nos termos de Foster, "precisamos saber os fatos- $\theta$ ( $\theta$-facts), e que, ao saber esses fatos, estamos T-teorizando ( $T$ theorizing)" (Foster 1976: 20).

Em decorrência do exposto acima, Foster propõe, então, uma alteração da versão que ele atribui a Davidson: é preciso saber não somente as proposições da teoria, mas saber que a teoria expressa essas proposições. Ele formula essa mudança no seguinte enunciado:

$\beta$. Saber que uma teoria-T para L expressa ... é suficiente para compreender L. 
onde ,... é preenchido pelos axiomas da teoria, indicando que a condição é saber o significado de cada axioma. Desse modo, se alguém sabe o significado dos axiomas de T, e que eles são axiomas de $\mathrm{T}$ para $\mathrm{L}$, então ele pode, a partir deste conhecimento, inferir para cada sentença de $\mathrm{L}$ o seu significado. Foster, para ilustrar isso, convida-nos a considerar uma sentença $\mathrm{S}_{\mathrm{i}}$ de $\mathrm{L}_{\mathrm{s}}$. Se um semanticista sabe $(\beta)$ para $L_{s}$, então ele sabe que uma teoria $T$ para $L_{s}$ expressa o conteúdo de

\section{6. $\mathrm{S}_{\mathrm{i}}$ é verdadeira $\leftrightarrow$ todo $\mathrm{x}$ é $\mathrm{F}$}

onde (6) é a sentença-T de $S_{i}$. Do que se segue que o semanticista pode inferir, em posse de $(\beta)$ e (6), que

(i) Alguma teoria-T para L tem como consequência lógica uma sentença que expressa que $S_{i}$ é verdadeira $\leftrightarrow$ todo x é $F$.

(ii) Alguma teoria-T para L tem uma sentença-T cujo lado esquerdo da implicação descreve $\mathrm{S}_{\mathrm{i}}$, e cujo lado direito expressa que todo $\mathrm{x}$ é $\mathrm{F}$.

(iii) Uma sentença que expressa que todo x é $\mathrm{F}$ traduz $\mathrm{S}_{\mathrm{i}}$.

(iv) Logo, $\mathrm{S}_{\mathrm{i}}$ significa que todo $\mathrm{x}$ é $\mathrm{F}$.

A generalização, então, que Foster propõe como alteração da tese sob ataque é: "para qualquer língua $X$, a teoria do significado para $X$ é o que resulta do esquema „Alguma teoria-T para $y$ expressa que $p^{\text {ee }}$, substituindo,$y^{\text {ee }}$ por um designador de $X$ e , $p^{\text {ee }}$ por uma teoria-T para $X^{\prime \prime}$ (Foster 76: 20). Mas mesmo que as condições propostas por ele possam se mostrar ainda insuficientes, faltando, segundo Lepore \& Ludwig, a restrição de que a sentença , $\mathrm{S}_{\mathrm{i}}$ é verdadeira $\leftrightarrow$ todo x é $\mathrm{F}^{\mathrm{ce}}$ não apenas seja consequência lógica de uma teoria-T, mas consequência de uma teoria-T cujos teoremas resultam de provas canônicas - ou seja, que isolam somente as sentenças-T que são interpretativas, bloqueando a introdução aleatória de tautologias ${ }^{125}$ - o requerimento de que se conheça, além do conteúdo que uma teoria-T expressa, também que ela expressa esse conteúdo, é uma condição necessária para que T seja usada para interpretar. Quanto a isso, Foster está correto. O problema reside na afirmação de que a tese de Davidson descartaria esta condição necessária, e que para ele uma teoria da verdade expressaria tudo o que é suficiente para interpretar uma língua, i.e., mais do que ela de fato pode fornecer.

\footnotetext{
${ }^{125}$ Os autores sustentam que sem um método de prova canônica e um conhecimento do método, não se pode passar com segurança de (iii) para (iv).
} 
Davidson nunca defendeu a tese que Foster atribui a ele. Não somente, respondendo a Foster, nega ter esta concepção, como não nos parece haver fonte textual suficiente nos primeiros textos programáticos, que são fundamentalmente os que Foster tem em perspectiva, para afirmar que Davidson sustenta tal tese. É fato que, particularmente em “Truth and Meaning”, não há uma elaboração precisa conectando o conhecimento do conteúdo que uma teoria da verdade expressa com o conhecimento de que a teoria expressa esse conteúdo. Aliás, Davidson reconhece em "Reply to Foster" que ele não foi feliz nos primeiros textos na tentativa "de dizer exatamente qual é a relação entre uma teoria da verdade e uma teoria do significado" (Davidson 1990 [1976]: 171), e em formular explicitamente o objetivo geral de uma teoria do significado por meio da indagação de "se a teoria proposta expressa algo cujo conhecimento seria suficiente para interpretar os enunciados dos falantes das línguas a que ela se aplica” (idem). É provável que Davidson ainda não estivesse mesmo suficientemente claro sobre esta relação, tampouco estivesse seguro sobre em que consistiria esse conjunto de conhecimento acerca de uma teoria da verdade. Essa inexatidão, e mesmo indefinição, deve-se fundamentalmente ao fato de que os primeiros textos programáticos expressam em parte essa teoria ainda em construção. O projeto visa especificar as informações que, uma vez de conhecimento de um teórico, coloca-o na condição de interpretar qualquer enunciado em potencial da linguagem objeto. Mas antes da determinação deste conhecimento suficiente e das condições para adquiri-lo, Davidson se concentra, nos casos de TMLL, TM e SNL, em adaptar uma teoria da verdade às línguas naturais, em viabilizar, por exemplo, a relativização do predicado de verdade aos contextos de uso, e sentenças com expressões indexicais. Em outros termos, o foco é, primordialmente, com base em casos específicos das línguas naturais que precisam ser acomodados para que se possa começar a usar uma teoria da verdade na construção de uma teoria do significado, dar forma a uma teoria-T aplicável a linguagens sensíveis ao contexto. Por isso, nestes textos Davidson não aprofunda, por um lado, a relação entre uma teoria que satisfaz a convenção-T e o conhecimento por um intérprete que ela a satisfaz, tampouco, por outo lado, enfrenta o problema de como confirmar a interpretatividade de uma teoria-T. Essas distinções são negligenciadas nesses textos, argumenta Davidson, porque, no percurso para implementar as modificações técnicas necessárias na forma de uma teoria-T que tenha uma língua natural como objeto, ele "imaginou que a teoria fosse conhecida por alguém que a tivesse construído a partir das evidências" (Davidson 1990 [1976]: 173) e cumprindo condições sobre o seu conhecimento que ainda teriam de ser determinadas. Como o próprio Davidson observa, de fato nos trabalhos mencionados ele não empreende uma distinção explícita entre a teoria da verdade em si e o corpo de conhecimento que alguém deve ter sobre ela para a usar para interpretar. Mas isso não autoriza a se concluir que essa distinção não está no horizonte do projeto. Uma investigação mais detalhada do conjunto dos textos 
programáticos, identificando um tecido de continuidade entre eles, como exposto no capítulo I, indica justamente que o objetivo do projeto é de determinar o papel que uma teoria da verdade cumpre no corpo de uma teoria do significado. O refinamento do seu projeto progride à medida também que Davidson vê a necessidade, motivado pelos questionamentos colocados por seus interlocutores diretos, de ser mais preciso e de consolidar melhor aspectos essenciais do seu projeto, para os quais respostas satisfatórias são mandatórias. A própria resposta a Foster é, sem dúvida, um texto no qual Davidson desenvolve de forma mais rigorosa sua posição quanto ao conhecimento sobre uma teoria-T.

O problema maior da objeção de Foster, contudo, reside na sua segunda etapa. Com a reformulação $(\beta)$ Foster intenda remediar o fato de que um intérprete pode estar em posse de uma teoria-T que satisfaz a Convenção-T e não saber que ela a satisfaz, e, por conseguinte, não saber algo suficiente para a interpretação. Foster argumenta que a sua solução evidencia que na especificacão do que alguém tem de saber sobre uma teoria-T é necessário fazer uso de noções intensionais, tal como ,„ma teoria-T expressa que...“. Ainda que necessário isso seria incompatível com as restrições que Davidson se impõe. Segundo ele, por duas razões: (i) o que seria suficiente saber não pode ser expresso em termos puramente extensionais, (ii) e para expressar esse conhecimento, portanto, tem-se de empregar uma lógica não extensional. Diz Foster

Interpretatividade, contudo, é o único mérito de $[\beta]$. Em todos os outros aspectos ele fica aquém das nossas demandas. Pois ele traz de volta o tipo de intensionalidade que conflita com nossos objetivos filosóficos: ele pressupõe o conceito de expressar e a sintaxe não extensional que ele carrega. Não há muito a se ganhar em deixar que a afirmação de Tteoricidade (T-theoreticity) e o conteúdo da teoria-T façam contato, se o único meio de nectá-los é pela linguagem intensional ,expressa que (Foster 1976: 21).

E mais à frente conclui:

Não vejo qualquer maneira de capturar a afirmação de T-teoricidade que assegure interpretatividade e evite intensionalidade. E se não há uma maneira, e se uma teoria da verdade por si própria é inadequada, o grande desenho de Davidson está em ruínas. A única questão que resta é o que deveríamos colocar em seu lugar (Foster 1976: 23).

Mas a convicção de que Davidson somente se permite uma lógica extensional é equivocada. Uma coisa é a lógica empregada na teoria da verdade, outra coisa é a linguagem necessária para especificar o conhecimento acerca da teoria. Esta distinção é essencial para uma apreciação adequada do projeto. De fato Davidson está comprometido com a ideia de que uma teoria da verdade para uma língua pode ser expressa em uma linguagem puramente extensional. Mas em nenhum momento ele sustenta que o conhenhecimento acerca de uma teoria da verdade suficiente 
para usá-la na interpretacão pode ser estalecido em termos tão somente extensionais. Há a respeito desta confusão uma passagem em "Reply to Foster" que não deixa dúvidas sobre Davidson não estar comprometido com o que Foster a ele atribui:

Foster pensa que meu grande plano está em ruínas porque ao tentar capturar, para garantiar a interpretatividade, a afirmação de T-teoricidade eu devo usar uma noção intensional como ,expressa" em „O intérprete sabe que alguma teoria-T expressa que.... Mas aqui ele atribui a mim um objetivo que nunca tive. Minha maneira de tentar fornecer uma explicação da linguagem e do singificado faz uso essencial de conceitos como os de crença e intenção [...]. O que tenho tentado é fornecer uma explicação do significado (interpretação) que não faz uso essencial de conceitos linguísticos não explicados. [...] Meu plano não será arruinado se para dizer o que um intérprete sabe é necessário empregar uma assim chamada noção intensional - uma [noção] habitualmente associada com crença e intenção e conceitos do tipo (Davidson 1990 [1976]: 175-176).

A acusação de que o uso de uma linguagem intensional seria incompatível com as condições que Davidson estipularia, de partida, para o sucesso da especificação do conhecimento necessário acerca de uma teoria-T, denota uma confusão quanto ao escopo da prescrição do uso de uma linguagem extensional. Davidson em nenhuma circunstância estabelece uma restrição quanto a expressar o conhecimento suficiente para a interpretação mobilizando expressões que criam contextos tradicionalmente chamados de opacos, como no caso de „uma teoria-T expressa que... “, que pode ser concebida como um operador não vero-funcional, uma vez que ao tomar sentenças materialmente equivalentes como argumentos, o resultado pode ser sentenças com valores de verdade distintos. O que Davidson requer é que uma lógica extensional seja empregada na teoria da verdade para gerar os teoremas-T. E aqui cumpre sublinhar um ponto adicional que esclarece ainda mais esta questão, pois a objeção de muitos filósofos ao projeto repousa sobre o equívoco de achar que Davidson acredita que uma teoria da verdade expressaria tudo o que alguém precisa saber para usá-la na interpretação. Parece-me que é esta leitura que motiva a visão distorcida de que Davidson espera expressar todo o conhecimento suficiente em uma linguagem extensional. Nunca é excessivo reforçar que, para Davidson, uma teoria do significado não é uma teoria da verdade, e ler o seu projeto desta maneira induz justamente a postura de associar a ele a expectativa de que uma teoria da verdade, munida de uma lógica estritamente extensional, pode realizar mais do que ela é de fato capaz. Uma teoria do significado deve se conformar como um conjunto de enunciados que estabelecem o que é suficiente para que uma teoria-T seja usada para interpretar uma língua (mais precisamente, fragmentos de uma língua). Disso se segue que, uma vez que se espera que os enunciados sobre o que é suficiente saber sejam enuncidados sobre a teoria da verdade, e não enunciados dela, não existe um comprometimento com excluir o uso de um vocabulário intensional. 
Para concluir esta seção é importante atentar para uma tese de Davidson que pode suscitar no leitor outra dúvida quanto ao problema do uso de um vocabulário intensional. Recordemos que no capítulo precedente Davidson intenta demonstrar, via o seu método paratático, que a semântica de construções aparentemente intensionais nas línguas naturais - como sentenças de discurso indireto e de crença - pode ser capturada via uma análise extensional. Esta tese pode ser compreendida como independente do que discutimos nos parágrafos anteriores. O sucesso da incorporação de tais contextos a uma teoria da verdade não afeta a questão do uso de uma lógica intensional para exprimir o conhecimento suficiente sobre uma teoria da verdade. A análise paratática destina-se, antes de mais nada, a fragmentos ditos intensionais das línguas naturais, ou seja, das linguagens objetos de uma teoria da verdade. O que deve ficar claro é que o problema de se enunciados da forma ,uma teoria-T expressa que $\mathrm{p}^{\text {ee }}$ podem eventualmente ser tratados por uma análise extensional, é uma questão que não precisa se articular com a primeira. Davidson até ensaia extrapolar, não sem complicações adicionais, a análise paratática para os enunciados teóricos do tipo $(\beta)$, sugerindo que tal percurso não seria de todo inconcebível, mas de começo já registra que o sucesso ou fracasso deste esforço não ameaça o seu projeto, uma vez que ele circunscrebe o imperativo do uso somente de um vocabulário extensional estritamente à teoria da verdade ${ }^{126}$.

\section{A teoria explícita do significado em Lepore \& Ludwing: a reificação voltando pela porta dos fundos?}

Lepore \& Ludwig propõem - em Donald Davidson: Meaning, Truth, Language, and Reality (2005) e Donald Davidson's Truth-Theoretic Semantics (2007) - uma especificação pormenorizada do que eles consideram o corpo de conhecimento suficiente sobre uma teoria da verdade para uma língua $\mathrm{L}$ que permite a um semanticista usá-la para interpretar as sentenças de L. Tal corpo de conhecimento, uma vez exibido, é chamado pelos autores de uma teoría explícita do significado. A convicção, como já discorrido nas seções anteriores, é de que "um conhecimento apropriado sobre uma teoria da verdade para uma língua [...] empodera quem o possui a interpretar qualquer sentença de uma linguagem objeto, e constitui um conhecimento equivalente àquele requerido por uma teoria composicional do significado" (Lepore \& Ludwig [2005] 210: 120). Se assim o for, então a exposição desse conhecimento suficiente revela-se uma teoria composicional explícita do significado, "uma vez que nos permite derivar para cada sentença da linguagem objeto, uma sentença-M apropriada” (idem), a saber, uma sentença do tipo ,para todo falante $S$, tempo $t, s$ significa para $S$ em $t$ que $p^{\text {ee }}$. Segundo os autores, numa teoria semântica de tipo davidsoniana, o que

\footnotetext{
${ }^{126}$ Ver p. 178 de "Reply to Foster".
} 
o teórico precisa saber para, via uma teoria-T, interpretar as sentenças de uma falante inclui: os axiomas da teoria, o que os axiomas significam, que a teoria é interpretativa, e um procedimento de gerar somente as sentenças- $\mathrm{T}$ interpretativas (prova canônica). Posto em uma lista, o intérprete precisa saber

$\beta^{\text {ee }}$ i. que uma teoria-T para $L$, com os axiomas $\alpha_{1}, \alpha_{2}, \ldots, \alpha_{n}$, é interpretativa;

ii. que $\Phi$ é uma prova canônica para $T$ (i.e., um procedimento que, relativo à suposição de que os axiomas são interpretativos, gera somente sentenças-T interpretativas);

iii. que o axioma $\alpha_{1}$ significa que $\mathrm{p}_{1}$, o axioma $\alpha_{2}$ significa que $\mathrm{p}_{2}, \ldots$, e que o axioma $\alpha_{\mathrm{n}}$ significa que $\mathrm{p}_{\mathrm{n}}$.

onde o que substitui $\Phi$ é uma descrição de um procedimento canônico. A ideia é de que, conhecendo $\left(\beta^{\text {ee }}\right)$, o teórico não somente sabe uma teoria-T interpretativa e o que ela expressa, mas também sabe que ele está em posse deste conhecimento. O que o capacitaria, mediante (i-iii) em $\left(\beta^{\mathrm{ee}}\right)$, de produzir composicionalmente, para cada sentença $s$ de uma linguagem ou fragmento de uma linguagem, uma sentença-T que interpreta $s$. O passo seguinte, para os autores, é evidenciar a articulação deste conhecimento acerca de uma teoria-T com uma teoria explícita do significado. Como fazer esta transição? Neste ponto, ele sugere a si mesma. Alguém que sabe (i-iii), ao gerar para uma sentença , $\mathrm{S}_{1}{ }^{e}$ de $\mathrm{L}$ uma sentença-T interpretativa do tipo , $\mathrm{S}_{1}$ é verdadeira em $\mathrm{L} \leftrightarrow \mathrm{p}_{1}{ }^{{ }^{e}}$, sabe que a sentença, $\mathrm{p}_{1}{ }^{e e}$, por ser uma tradução de, $\mathrm{S}_{1}{ }^{e e}$, pode aparecer como argumento numa sentença-M de, $\mathrm{S}_{1}{ }^{e}$. Um intérprete que gera uma sentença-T interpretativa para uma sentença de L com base no conhecimento de (i-iii), é capaz de inferir uma sentença-M adequada para ela. Nesse sentido, Lepore \& Ludwig, confiantes de que um enunciado que elenca o que um teórico precisa saber sobre uma teoria da verdade assegura o seu uso "para o propósito de uma teoria composicional do significado, a saber, interpretar cada sentença da linguagem objeto" (Lepore \& Ludwig [2005] 210: 120), propõem colocar esta teoria explícita para uma língua L da seguinte maneira:

$\delta$. i. Toda instanciação do seguinte esquema é verdadeira: para todo falante $\mathrm{S}$, tempo $\mathrm{t}, s$ para $\mathrm{S}$ em $\mathrm{t}$ significa em L que p se, e somente se, é passível de ser canonicamente provado com base nos axiomas de uma teoria-T interpretativa para L que, para todo falante $\mathrm{S}$, tempo t, $s$ para $\mathrm{S}$ em t é verdadeira se, e somente se, $p$;

ii. T é uma teoria interpretativa para $L$ cujos axiomas são $\alpha_{1}, \alpha_{2}, \ldots, \alpha_{n}$;

iii. o axioma $\alpha_{1}$ significa que $\mathrm{p}_{1}$, o axioma $\alpha_{2}$ significa que $\mathrm{p}_{2}$, 
o axioma $\alpha_{\mathrm{n}}$ significa que $\mathrm{p}_{\mathrm{n}}$;

iv. uma prova canônica em $\mathrm{T}$ é um procedimento que, relativo à suposição de que os axiomas são interpretativos, gera somente sentenças-T interpretativas).

Com $(\delta)$ Lepore e Ludwig acreditam exibir uma teoria explícita do significado como uma teoria expressa em termos de uma lista de conhecimento sobre uma teria da verdade. A articulação entre $\left(\beta^{\text {ee }}\right)$ e $(\delta)$ procura precisar o papel que uma teoria da verdade deve cumprir em uma teoria do significado. Esta conexão está em conformidade com a observação de Foster que não basta que uma teoria-T seja interpretativa, pois é preciso que se saiba que ela o é.

Delineado acima como Lepore e Ludwig exibem os enunciados que expressariam o conhecimento sobre uma teoria-T interpretativa suficiente para empregá-la na interpretação, pretendo, nas linhas que se seguem, concentrar-me em algumas considerações sobre uma consequência indesejada que creio identificar a partir de uma avaliação do quadro que emerge em $\left(\beta^{\text {ee }}\right)$ e $(\delta)$. Na forma como os autores elencam este conhecimento, não estou persuadido de que eles conseguem evitar de incorrer numa reificação do conteúdo semântico expresso pelos axiomas, ao explicitarem como uma condição que o intérprete saiba o que os axiomas significam. Não me parece difícil mostrar por que isso ocorre.

$\mathrm{Na}$ teoria dos autores, é estabelecida, entre outras condições - tendo em perspectiva o debate entre Foster e Davidson acerca do tema - que não basta saber o conteúdo informacional expresso pelos axiomas de uma teoria da verdade. É preciso saber também quais conteúdos os axiomas veiculam. Isto é, tem-se que saber os sentidos dos axiomas. Aqui reside, a meu ver, o impasse. Ao detalhar na forma de uma teoria explícita esse conhecimento, $\left(\beta^{e e}\right)$ associa, por meio de uma lista, um sentido/intensão a cada axioma. Ou seja, para cada expressão da linguagem objeto deve haver um axioma na teoria, e o sentido desse axioma deve ser conteúdo conhecido pelo semanticista/intérprete para que ele seja capaz de empregar a teoria-T para interpretar as expressões subsentenciais e as sentenças da linguagem objeto. Se os sentidos de todos os axiomas listados são estabelecidos como conteúdos de conhecimento do intérprete, uma consequência de ( $\left.\beta^{\text {ce}}\right)$ é que para todo axioma $\mathrm{x}$ de uma teoria-T para $\mathrm{L}$ existe um significado $\mathrm{y}$, tal que $\mathrm{x}$ significa $\mathrm{y}$, e que para interpretar L via $\mathrm{T}$ tem-se que saber que x expressa y. Posto de outra maneira, em ( $\beta^{\text {ee }}$ ) parece não ser possível se furtar a uma forma de quantificação em que as entidades percorridas pelas variáveis são os significados expressos pelos axiomas. Esta reificação dos conteúdos informacionais dos axiomas indica que o comprometimento ontológico da teoria $\left(\beta^{\text {ee }}\right)$ é dependente da sua própria estrutura, e que a noção de significado como entidade cumpre um papel explicativo nela. A 
generalização „o teórico tem que saber o significado de todo axioma é um enunciado previsto na teoria, ainda que em $\left(\beta^{\text {ee}}\right)$ ele não esteja explicitada, e a sua regimentação alcançada via notação canônica mostra que a verdade deste enunciado depende de que a pressuposição de existência embutida na descrição definida „o significado“e seja satisfeita. Parece não haver alternativa senão interpretar a cláusula (iii) de $\left(\beta^{\text {eq }}\right.$ ) como tomando os significados dos axiomas como objetos da attitude proposicional ,saber que

Se a posição acima estiver correta, algumas conclusões importantes sobre a teoria de Lepore \& Ludwig podem ser arriscadas. Em primeiro lugar que, embora a teoria da verdade evite o apelo direto a significado como entidade, o fato de a teoria do significado dos autores, concebida como um corpo de conhecimento sobre uma teoria da verdade, acarretar a reificação dos sentidos dos axiomas da teoria da verdade, demonstra que a semântica que constroem não cumpre o propósito de ser uma teoria imune a reificar sentidos. A reificação expulsa pela porta da frente é reintroduzida disfarçadamente pela porta dos fundos. Em segundo lugar, a ausência de uma determinação do que são esses conteúdos expressos pelos axiomas - a neutralidade quanto à adoção de uma posição quanto a sua natureza (se extra ou intra-linguística), ou a falta da formulação de condições de identidade/individuação - não protege a teoria explícita do significado dos autores de entificar esses conteúdos.

Estas duas conclusões, por seu turno, motivam um passo a mais, suscitando a seguinte a pergunta: esta associação sistemática de um conteúdos semântico a cada axioma, via quantificação, implicaria o assinalamento de entidades às expressões da linguagem objeto e suas traduções na metalinguagem? Posto em outras palavras, do fato de a teoria imputar um sentido reificado a todos os axiomas se seguiria que a teoria reifica os significados dos termos da linguagem objeto? Se o sentido de um axioma for compreendido como uma função dos sentidos de suas partes, ao que tudo indica não há como contornar esta consequência. Todo axioma menciona uma expressão da linguagem objeto e usa uma expressão da metalinguagem que serve de tradução do termo mencionado. Desse modo, para conhecer o sentido de um axioma é preciso que o teórico saiba o sentido da expressão usada do lado direito dele, que, como sua unidade constituinte, ou seja, um argumento da sentença que forma o mesmo, participa do todo complexo que é o axioma. O resultado, bastante natural, é que este argumento do lado direito, como expressão que exibe o sentido do termo da linguagem objeto mencionado do lado esquerdo, por veicular um conteúdo reificado, imputaria o mesmo à expressão que traduz. Ou seja, o comprometimento em $\left(\beta^{\text {ce }}\right)$ com uma quantificação sobre os sentidos dos axiomas da teoria da verdade implicaria a reificação dos sentidos conferidos aos termos e sentenças da linguagem objeto. 
Em síntese, o que se observa é que a reificação se expressa na própria estrutura da teoria explícita, e que se nos atermos a como ela é construída em $\left(\beta^{\mathrm{ee}}\right)$ e reelaborada em $(\delta)$, não consigo conceber como que a reificação dos sentidos possa ser removida de uma teoria composicional do significado. No modelo dos autores, a adoção de significados como entidades se torna inevitável. A convicção, portanto, de Lepore e Ludwig de terem fornecido uma teoria na qual "pudéssemos recobrir nossa inocência pré-fregeana", como desejou Davidson, parece não sobreviver, se estivérmos corretos, a um exame mais atendo dos comprometimentos que acarreta.

\section{Explorações preliminares de um tópico para um futuro estudo: o método do intérprete radical como receituário para enfrentar a reificação.}

O projeto de Davidson se diferencia do percurso traçado por Lepore \& Ludwig em aspectos decisivos, entendo, para se avaliar o sucesso ou fracasso de uma semântica que nega "que ter um significado ou intensão envolve uma entidade, e, portanto, [...] a existência de expressões que se referem a tais entidades" (Davidson 1963: 299). O que Lepore \& Ludwig adotam como dado de partida, e, ao menos para seus propósitos, salvo de disputas, é justamente o problema para o qual Davidson precisa fornecer uma solução satisfatória, sem a qual o próprio projeto está sob risco. É essencial considerar que não está à disposição de Davidson simplesmente pressupor, de antemão, que os axiomas de uma teoria da verdade são interpretativos - i.e., que os axiomas coordenam pares de expressões usadas na metalinguagem para especificar as condições de verdade com expressões da linguagem para as quais eles servem de traduções - e parar por aí. Notem que é estabelecendo de início a condição de que os termos do lado direito dos axiomas são traduções, que consigo utilizar uma lógica extensional para fornecer composicionalmente sentenças-T interpretativas. Todavia, este recurso não é senão uma reedição, para as línguas naturais, da agenda tarskiana: tomar como pressupostas as noções de tradução e sinoníma, de maneira a construir uma definição de verdade para uma linguagem objeto. Obviamente, Lepore \& Ludwig não ignoram o fato de que Davidson não se contenta com a ideia de que para fornecer uma teoria composicional do significado basta simplesmente elencar o conhecimento suficiente acerca de uma teoria da verdade já tomada como interpretativa: com axiomas que exibem traduções e um método canônico de prova para derivar unicamente sentenças-T com traduções do lado direito. Há mais um passo a ser dado, o qual Davidson chama de "restrição empírica" (empirical constraint). A saber, um método de perseguir "as evidências potencialmente disponíveis a um potencial intérprete" 127 que assegurariam confirmar a interpretatividade de uma teoria da verdade. O que se quer é traçar uma relação entre os

\footnotetext{
${ }^{127}$ Davidson 1999 [1973]: 125.
} 
conceitos semânticos de sinonímia, tradução, mesmo conteúdo empregados na teoria, e noções mais básicas como disposições para reagir a enunciados de sentenças em situações determinadas, via uma estratégia que mostre que aqueles conceitos teóricos podem ser empiricamente aplicados com base em evidências que fornecem motivações suficientes para se interpretar um falante sem apelar de antemão a eles. Como mostrarei mais à frente, tal percurso de confirmação, chamado de o método do intérprete radical, adota o conceito de verdade como básico, manifesto na atitude proposicional de tomar sentenças por verdadeiras, para lançar sobre os conceitos semânticos mencionados, aos quais são comumente associadas noções intensionais. O equívoco de Lepore e \& Ludwig não reside em cindir as duas fases articuladas - (i) fornecer uma teoria da verdade como um meio de construir uma teoria composicional do significado sem apelo à reificação e (ii) um método de confirmar a sua viabilidade - cuja conjunção constitui o projeto semântico de Davidson, mas em crer que (i) já seja suficiente como uma semântica que não incorre no comprometimento com os sentidos das expressões como entidades. Antes de percorrer, de forma panorâmica, o método do intérprete radical, quero demarcar aqui que não intento realizar um exame dele com o propósito de se posicionar quanto à questão de se ele cumpre o que se propõe. Há na literatura um profícuo debate sobre o assunto, e qualquer posição minimamente rigorosa a seu respeito demandaria uma investigação cujo resultado seria um trabalho das dimensões de uma tese. O que pretendo, nesta seção, é tão somente fornecer os elementos suficientes para que o leitor aprecie o propósito por trás da introdução do método como parte substancial do projeto semântico de Davidson, e atentar para o fato de que a cisão que Lepore \& Ludwig encampam tem consequências nocivas, se minha objeção for correta, para o tipo de semântica ambicionada pelos autores. Independentemente de se as restrições sobre as evidências propostas para a interpretação venham a se revelar insuficientes para garantir um emprego de noções intensionais sem incorrer em reificações, é-me basta claro que, para Davidson, o sucesso da viabilidade de uma teoria do significado deste tipo depende do intérprete radical cumprir o papel para o qual foi desenhado.

Assumido que uma teoria da verdade possa servir para a interpretação das sentenças do falante de uma língua, e que, como tal, tenha um papel empírico, a questão que emerge é como podemos confirmar uma teoria de modo a assegurar que, em posse do conhecimento dela, podemos usá-la para derivar sentenças-T que exibem interpretações das sentenças da linguagem objeto. Como Davidson coloca: "dado uma teoria que tornaria a interpretação possível, quais evidências plausivelmente disponíveis a um potencial intérprete dariam suporte à teoria em um grau razoável?" (Davidson 1999 [1973]: 125). Ou seja, com base em quais evidências hipotéticas é possível dizer que uma teoria da verdade pode ser usada para fornecer traduções adequadas? No texto "Radical Interpretation", Davidson procura justamente fornecer algumas respostas. Ele defenderá que o que 
constitui a posição evidencial do intérprete radical será suficiente para confirmar a interpretatividade de uma teoria-T. Lembremos que uma ambição nuclear do projeto de Davidson consiste em procurar iluminar os conceitos semânticos relacionando-os a noções mais básicas, não no sentido de fornecer análises que reduzam aqueles a estes, mas de mostrar como evidências descritas com o uso de conceitos mais básicos podem mostrar como que os conceitos centrais de uma teoria do significado podem ser empiricamente aplicados. É neste contexto que entra em cena a adoção do ponto de vista de um intérprete radical como método que visa garantir como os conceitos de uma teoria do significado são passíveis de serem aplicados com base em evidências que podem ser descritas sem fazer uso essencial de tais conceitos, e que são suficientes para garantir o seu emprego heurístico. A concepção desta estratégia é motivada em parte pela posição de Davidson de que tudo o que diz respeito à interpretação e significado deve estar articulado com evidências publicamente disponíveis aos falantes, ou seja, o que uma pessoa significa com suas palavras deve ser, em princípio, determinado por fatos observáveis publicamente. Davidson compreende a linguagem como um fenômeno intrinsecamente social, e sustenta que se há alguma evidência última que alicerça a atribuição adequada de significados são fatos observáveis sobre os quais o significado se assenta. O ponto crucial a destacar aqui é que Davidson espera que qualquer evidência em suporte ou contra uma teoria da verdade deve aparecer na forma de eventos ou situações que levam o falante a tomar por verdadeira ou falsa cada sentença que constitui seu repertório. Em outras palavras, evidências para se confirmar a interpretatividade de uma teoria da verdade para uma língua devem ser exibidas como fatos da comunicação linguística que estariam, em princípio, disponíveis tanto ao falante quanto ao intérprete. O que Davidson chamará de "restrição empírica" de uma teoria da verdade como veículo de uma teoria do significado, como veremos em seguida, é o requerimento de que ela seja justamente confirmada pelo método do intérprete radical. Vejamos então como ele o concebe.

De inspiração claramente quineana, o intérprete radical é concebido como um linguista imaginário de campo confrontado com falantes de uma língua que ele desconhece completamente. Os fatos semânticos com os quais o linguista se defronta são, a princípio, exauridos pelos fatos disponíveis ao intérprete radical, todos eles publicamente observáveis. Daí o primeiro requerimento de que

[...] A evidência deve ser de um tipo que estaria disponível a alguém que ainda não sabe como interpretar enunciados que a teoria é desenhada para cobrir: ela deve ser uma evidência que pode ser expressa sem o uso essencial de conceitos linguísticos tais com significado, interpretação, sinonímia, e outros do mesmo tipo (Davidson 1990 [1973]: 128). 
No quadro proposto, o linguista terá de explorar as disposições comportamentais do falante (informante) em face dos eventos e circunstâncias observáveis por ambos. A expectativa é de que, em coordenação com algumas condições que regulariam o processo de interpretação (princípio de caridade), o intérprete radical possa, em um grau razoável de confiança indutiva, ao identificar os fatos disposicionais relevantes, predominantemente padrões de atitudes de assentir e dissentir em face de sentenças confrontadas com eventos salientes do ambiente, produzir interpretações satisfatórias, ou seja, que melhor se ajustem às evidências ${ }^{128}$. Recordemos aqui que a Convenção- $\mathrm{T}_{\mathrm{r}}$ estipula que uma teoria-T é adequada se ela gera uma sentença-T interpretativa para cada sentença da linguagem objeto, i.e., sentenças-T que fornecem traduções das sentenças mencionadas. E, embora a teoria trate tais sentenças como unidades formadas de termos subsentenciais, empregando conceitos como o de satisfação e referência na conformação dos axiomas, visto que Sentenças-T

\footnotetext{
${ }^{128}$ Cumpre elucidar algumas distinções determinantes entre os horizontes de Quine e Davidson quando da utilização do caso imaginado do linguista de campo. Quine era profundamente cético quanto a expectativas de se formular uma semântica sistemática para as línguas naturais. Sua tese da indeterminação da tradução - na fundamentação da qual o caso do linguista de campo confrontado com uma língua desconhecida, que ele chama de „Jungleee, cumpre um papel substancial - leva-o a concluir que não há fatos observáveis que, em última instância, assegurem uma única tradução. São problemas dessa ordem que levam Quine a formular a tese da indeterminação da tradução. Tese segundo a qual "sistemas rivais [...] de hipóteses podem se conformar a todas as disposições de fala de cada uma das línguas em questão e ainda ditar, em incontáveis casos, traduções completamente díspares" (Quine 1960: 73). É possível haver dois manuais de tradução que consigam ter o mesmo poder de explicação e previsão, i.e., que expliquem as disposições comportamentais dos falantes de uma língua, mas que, ainda assim, cada um desses manuais "pode prescrever algumas traduções que o outro [...] rejeitaria" (Quine 1990: 48). No limite, significa que é possível atribuir a uma sentença significados excludentes que se conformem à disposição comportamental do falante em relação à sentença. A correção dessa tese é talvez o mais forte argumento contra a hipótese de que o significado de uma sentença é a proposição que ela compartilha com suas traduções em outras línguas. A conclusão cética de Quine é que, uma vez que não há fatos que determinem o que uma sentença significa, não há fatos para uma teoria semântica descrever ou explicar. Para Quine, o empreendimento de fornecer manuais de tradução é de ordem prática, e a adoção de um manual em detrimento de outro segue o critério de escolher aquele que melhor contribui para as finalidades da comunicação. Davidson, embora aceite a tese da indeterminação, partilhando da premissa de que não existe uma única melhor tradução ou interpretação, ele não extrai disso uma conclusão cétida quanto à viabilidade de uma semântica para as línguas naturais. Para Davidson, duas teorias da verdade igualmente confirmadas pelos mesmos fatos são ambas corretas, e, portanto, ambas podem ser concebidas como interpretativas. A conclusão cética de que a indeterminação seria um argumento contra a existência de sentidos e, por extensão, contra a justificativa de uma teoria semântica, é, entende Davidson, apenas justificável se se espera que sentidos sejam entidades individuáveis por fatos observáveis. Do ponto de vista de Davidson, o inovador da metodologia do tradutor radical foi justamente apontar uma mudança de foco do empreendimento de dizer que tipos de entidades são os sentidos para a tentativa de interpretar sentenças de uma linguagem objeto via sentenças de outra linguagem. Mas, para concluir esta nota, que, como salta aos olhos, toca num tema nevrálgico e bastante controverso, e que, demandaria, para uma investigação apropriada, o espaço de uma tese, é importante mencionar mais um elemento da posição de Davidson. Ainda que a indeterminação entre duas teorias semânticas não seja fonte de pessimismo para Davidson, fato é que, no desenvolvimento mais tardio da sua filosofia, ele empreende, em parte com o proposito de tentar reduzir a proliferação potencial de teorias conflitantes confirmáveis pelos mesmos fatos, acomodar o método do intérprete radical no corpo de uma teoria da decisão, na qual não somente a atitude de tomar por verdadeiro é aceita como evidência; é também introduzida a atitude de preferência entre sentenças. A ideia é que, via a coordenação de padrões de assentir e dissentir em relação a sentenças observacionais, que descrevem eventos circundantes, com fatos sobre preferências sobre a verdade de sentenças, é possível extrair, com base em uma versão da teoria bayesiana da decisão, condições de verdade corretas para as sentencas de um fragmento de uma língua objeto. Essa menção é apenas para salientar que uma apreciação mais detalhada das transformações por que passa o método do intérprete radical no desenvolvimento da filosofia de Davidson intenta também responder a insuficiencias que o método apresenta nas suas primeiras versões.
} 
mencionam somente sentenças fechadas da linguagem objeto, ela somente "implica resultados testáveis na forma de sentenças-T, e essas não mencionam o maquinário [da teoria]" (Davidson 1990 [1973]: 133). Por isso, a base evidencial, acessível à verificação direta, são fundamentalmente sentenças e o comportamento dos falantes em relação a elas em articulação com o ambiente circundante. A teoria da verdade pode ser testada, portanto, "apenas pelo o que ela diz sobre as sentenças" (idem) realizadas em contextos determinados. Isto posto, a estratégia é de "começar com a atitude de tomar uma sentença por verdadeira" (idem). E, a partir dela, começar a construir e articular as outras evidências e condições subsequentes. É à luz desta estratégia que se deve compreender quando Davidson diz que "Tarski foi capaz de definir verdade; a ideia presente é de tomar verdade como básica e extrair uma explicação de tradução ou interpretação" (idem). Dado a centralidade, presumivelmente, do conceito de verdade na elaboração do intérprete radical, Davidson crê que, sendo a atitude de tomar por verdadeiro uma atitude de crença passível de ser aplicada por um falante a muitas sentenças, e plausível de ser identificada pelo intérprete "antes que ele possa interpretar, uma vez que ele pode saber que uma pessoa intenta expressar uma verdade ao enunciar uma sentença sem ter qualquer ideia de qual verdade" (idem), ela será a evidência - que integra a posição epistêmica do intérprete radical - por meio da qual se coordenará a relação entre falante, linguagem e ambiente circundante; relação essa que será a condição determinante para se chegar à interpretação das sentenças via o método proposto. A ambição é de que como base evidencial disponível para confirmar uma teoria da verdade bastam as atitudes de tomar por verdadeiro/falso enunciados de sentenças, os momentos e circunstancias sob as quais verdade ou falsidade são a elas atribuídas, mais a identificação da comunidade linguística.

A título de exemplo, e de maneira bastante simplificada ${ }^{129}$, mas suficiente para nossos propósitos aqui, suponha que um linguista de campo, após alguns testes, esboce a seguinte sentença-T para um enunciado da uma língua desconhecida - chamemos ela de „Ioritáee - e cujo informante é um falante nativo da língua e monolíngue:

$\alpha$. Para todo falante x e todo tempo t, „Ak-antãee é verdadeira em Ioritá quando falada por x no tempo t se, e somente se, está ensolarado próximo de $\mathrm{x}$ no tempo $\mathrm{t}$.

Agora, por seu turno, imagine as seguintes evidências:

${ }^{129}$ Exemplo adaptado de Davidson (1999 [1973], pg. 135). 
$\alpha^{e e}$. O falante x pertence à comunidade de fala da língua Ioritá, e x toma por verdadeira „Ak-

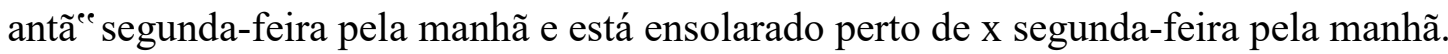

Para Davidson, $\left(\alpha^{e e}\right)$ pode servir de primeiras evidências de que $(\alpha)$ pode vir a ser uma sentença-T satisfatória para „Ak antãee. Mas, uma vez que $(\alpha)$ é uma generalização com quantificação universal sobre falante e tempo, mais amostragens, presumivelmente, precisam ser juntadas de maneira a sustentar um enunciado da forma

$\alpha^{\text {eee }}$. Para todo falante $\mathrm{x}$ e todo tempo $\mathrm{t}$, se $\mathrm{x}$ pertence à comunidade de fala da língua Ioritá, então x toma por verdadeira ,Ak-antãee em t se, e somente se, está ensolarado perto de x em t.

Neste quadro, a atitude de tomar por verdadeiro deve ser detectável com base no comportamento observável. O seu papel no método é de iluminar a relação entre os conceitos semânticos da teoria e a evidência não linguística na tentativa de confirmar que se está em posse de uma teoria-T que cumpre os requisitos dela esperados. Aqui o leitor, com razão, pode indagar: mas x, e outros informantes que, por ventura, reforcem a convicção da correção de ( $\alpha^{\text {eeec }}$, podem estar errados, mentindo, sendo irônicos, etc. Sim, de fato isso é completamente plausível. Mas cumpre chamar a atenção para o fato de que Davidson tem por intuito conceber evidências hipotéticas que possam confirmar uma teoria-T. O que se busca são generalizações que, ainda que passíveis de revisões, devem evitar, o quanto possível, interferências que possam ocorrer com frequência em condições reais de interpretação. ${ }^{130}$ Por isso, a resposta elaborada por Davidson acerca de como podemos confirmar a interpretatividade de uma teoria-T não se restringe às evidências mencionadas. É introduzido também o "conselho metodológico" de que o intérprete radical deve interpretar de um modo "que maximize concordância", no sentido de pressupor, o quanto puder, que o falante é sincero e está dizendo a verdade. Ele o chama de Princípio de Caridade. Davidson entende que uma condição para que um falante seja interpretável é tratá-lo como uma criatura cujas crenças são em geral verdadeiras, coerentes, e muitas das quais são partilhadas com o intérprete. Há, segundo Davidson, uma interdependência entre crença e significado, e a atribuição de uma crença a alguém se dá sempre via interpretação linguística. Um falante que toma sinceramente uma sentença da sua

\footnotetext{
${ }^{130}$ Davidson não intenta com a aplicação do intérprete radical investigar como adquirimos nossa língua materna ou uma outra língua, partindo da hipótese de que a interpretação radical estaria envolvida em toda interpretação. A preocupação não é, como ele diz na introdução de "Radical interpretation" com "a história real da aquisição de linguagem" (p.g. 125), e, portanto, de formular uma hipótese sobre como se aquiquire uma língua, mas sim de demonstrar que uma teoria da verdade pode ser verificada por seu método.
} 
língua por verdadeira o faz em virtude do que ela significa e das suas crenças. Assim, se soubermos que um falante toma uma sentença por verdadeira, e soubermos o significado dela, podemos inferir a sua crença. Mas para o intérprete radical está vetado, de antemão, com exceção da atitude de tomar sentenças por verdadeiras, o acesso às atitudes proposicionais do falante, já que ele desconhece os significados dos termos da língua do mesmo. Por isso, pressupor que as crenças do falante sejam em geral verdadeiras e partilhadas por quem o interpreta, torna-se uma condição, no contexto do intérprete radical, para que o falante seja em princípio interpretável. Isso porque, entende Davidson, uma vez que se desconhece a crença do falante, pressupor a sua verdade revelase a única garantia de que se possa, à luz do ambiente que circunda falante e intérprete, apreender o que ele acredita e compreender o significado da sentença que toma por verdadeira. A justificativa mais geral para o Princípio de Caridade é que ele consiste numa condição reguladora que governaria a interpretação. O que se assumiria ao interpretar uma sentença $S$ enunciada por um falante, então, é que se x toma por verdadeira $S$ se, e somente se, x acredita que p, então $S$ significa que $p$. Assim, se o conteúdo de uma crença for identificado com base, por sua vez, na identificação da atitude de tomar uma sentença por verdadeira sob dadas circunstâncias, é possível, pensa Davidson, especificar condições de verdade da sentença que são interpretativas, ou seja, que sejam colocadas na forma de uma sentença-T que traduz a sentença alvo. Evidentemente que este tema suscita muitas questões, e está longe de ser esgotado, não seria nem preciso dizer, em um parágrafo. Mas como já sublinhado, aqui estou apenas percorrendo panoramicamente os conceitos e condições que operam na conformação do método do intérprete radical, de maneira a situar o seu papel no projeto semântico de Davidson. Há uma passagem em "Reply to Foster" bastante elucidativa desse objetivo de fornecer "restrições empíricas" que possam regular o teste da interpretatividade de uma teoria-T:

\footnotetext{
Uma vez que Tarski estava interessado em definir verdade, e estava trabalhando com linguagens artificiais onde a estipulação pode substituir a iluminação, ele podia tomar o conceito de tradução como pressuposto. Mas na interpretação radical isso não pode ser assumido. Então, eu propus em vez disso algumas restrições empíricas sobre a aceitação de uma teoria da verdade que podem ser expressas sem apelo a noções tais como significado, tradução ou sinonímia, embora não sem certo entendimento da noção de verdade. [...] Tenho tentado mostrar que se as restrições são cumpridas pela teoria, as sentenças-T que emanam dela terão de fato traduções de $s$ substituindo ,pp (Davidson 1999 [1976]: 172).
}

As condições e evidências de que tratamos e que conformam a base evidencial à disposição do intérprete radical são o que Davidson concebe como constituindo "as restrições empíricas”. Do que se segue que, se o teórico (i) sabe que sua teoria-T cumpre essas restrições, ou seja, é confirmada do ponto de vista do intérprete radical, (ii) sabe também a linguagem da teoria, e (iii) sabe, por fim, que 
cumprir as restrições empíricas e as formais ${ }^{131}$ é suficiente para que a teoria satisfaça a ConvençãoT, então tal teoria pode fornecer uma tradução para cada das sentenças do fragmento de linguagem sob investigação. Em síntese, ele pode empregá-la para interpretar as sentenças em questão. Tal teoria (ou teorias) deve ser a que melhor se adequa ao conjunto das evidências disponíveis para um intérprete radical. Assim, visto que uma condição substancial para que uma teoria-T seja interpretativa é que ela seja testável do ponto de vista do intérprete radical, o corpo de conhecimento sobre uma teoria-T pode ser posto da seguinte maneira:

$\lambda$. i. A teoria-T para $\mathrm{L}$, com os axiomas $\alpha_{1}, \alpha_{2}, \ldots, \alpha_{\mathrm{n}}$, é confirmável do ponto de vista do intérprete radical;

ii. o axioma $\alpha_{1}$ significa que $p_{1}$, o aximo $\alpha_{2}$ significa que $p_{2}, \ldots$, e que o axioma $\alpha_{n}$ significa que $\mathrm{p}_{\mathrm{n}}$;

iii. $\Phi$ é uma prova canônica para $T$.

A lista $(\lambda)$ se distingue da lista $\left(\beta^{\text {ee }}\right)$ de Lepore \& Ludwig exatamente na sua cláusula (i), que não simplesmente estipula que a teoria-T é interpretativa. Pelo contrário. Ela requer que a sua interpretatividade decorra do fato de ela ter sido verificada por um método cujas evidências podem ser descritas sem pressupor o emprego dos conceitos que se quer iluminar. O que se espera, com isso, é que saber os significados dos axiomas, isto é, saber (ii), seja respaldado por (i). É a base evidencial do intérprete radical que, ao confirmar a interpretatividade de $\mathrm{T}$, a salvaguardaria de incorrer na postulação de sentidos como entidades ${ }^{132}$. É crucial compreender que, para Davidson, sua teoria do significado é indissociável da elaboração de um método de confirmação de que uma teoria-T é interpretativa ${ }^{133}$. É o procedimento do intérprete radical o método de teste de se uma teoria da verdade pode desempenhar o papel de uma teoria do sentido. A ausência de uma estratégia que indique como se chegar a uma tradução adequada via uma teoria- $\mathrm{T}$, ao estabelecer como condição acerca do conhecimento de uma teoria-T interpretativa que se saiba que ela é interpretativa, toma como pressuposto a noção de tradução. O que uma teoria que pressupõe esse conceito não faz é justamente iluminar significado (na acepção de sentido/intensão). Para perseguir

\footnotetext{
${ }^{131}$ As restrições formais são: a teoria deve ser colocada em uma forma finita, com cláusulas que fornecem as condições de satisfação dos termos da linguagem objeto, e regras de composição. Ver capítulo I.

${ }^{132}$ Inclusive há espaço para indeterminações. É suficientemente razoável imaginar duas ou mais sentenças-T para uma mesma sentença s sendo confirmadas pelo mesmo conjunto de evidências. Para Davidson, não há nada que impeça, com base apenas nestas evidências, de concebê-las como interpretativas.

${ }^{133}$ Em última instância, o meio de medir "empiricamente" o sucesso de uma teoria-T para um fragmento de uma língua natural, de dizer que ela satisfaz a Convenção- $\mathrm{T}$ - no sentido de fornecer, via sentenças- $\mathrm{T}$, traduções adequadas - e estaria, portanto, apta para fornecer o significado das sentenças investigadas, seria demonstrar que ela pode ser confirmada do ponto de vista do intérprete radical.
} 
isso é essencial em algum momento abandonar tal pressuposto. É a possibilidade, acredita Davidson, de que a interpretatividade de uma teoria-T possa ser verificada mediante um método que, sem apelar às noções que se quer iluminar, demonstra que elas são empiricamente aplicáveis, que asseguraria o não comprometimento de uma teoria semântica com a reificações explícitas dos sentidos das expressões.

Em resumo, concluindo esta seção, sem a concepção de um procedimento como o intérprete radical, e sua incorporação como aspecto constitutivo de uma teoria semântica - ou seja, apenas circunscrevendo esta ao que pode ser abarcado em $\left(\beta^{\text {ee }}\right)$ - parece não haver muita coisa que diferencie substancialmente, quanto à reficação dos sentidos das expressões, uma semântica dita “davidsoniana" de uma semântica de tradição fregeana. O sucesso de uma teoria do significado tal como concebida por Davidson depende de que o método do intérprete radical cumpra o seu propósito: mostrar que os conceitos do "campo" intensional empregados em uma teoria-T, ao serem iluminados por uma estratégia que não os pressupõe, em que um intérprete ideal constrói sentenças$\mathrm{T}$ interpretativas para fragmentos da língua de um falante com base fundamentalmente em evidências de fatos publicamente observáveis, não acarretam o compromisso com sentidos como entidades. Sem isso, uma teoria do significado que recorra a uma teoria da verdade de tipo tarskiana não se revela ontologicamente mais austera do que teorias neo-fregeanas que, de partida, assinalam explicitamente sentidos às expressões de uma linguagem objeto. ${ }^{134}$

\footnotetext{
${ }^{134} \mathrm{O}$ procedimento do intérprete radical não é uma estratégia introduzida a posteriori no projeto. Ainda que não desenvolvida nos textos programáticos, já há em alguns deles referência ao método. As primeiras descrições do intérprete radical como aspecto constitutivo do projeto, mencionando os seus temas principais, já aparecem em "Truth and Meaning", p. 27: que as evidências disponíveis para a interpretação são sentenças tomadas por verdadeiras ou falsas em face das circunstâncias acessíveis a falante e intérprete, a exigência de que se considere o falante na maioria dos casos como dizendo a verdade e que se pressuponha sua racionalidade (princípio da caridade), assim como o fato de que estas restrições não evitam a indeterminação.
} 


\section{CONCLUSÃO}

Na presente tese investigamos o projeto de Davidson de fornecer uma semântica composicional para as línguas naturais por meio do emprego de uma teoria tarskiana da verdade. Concentramo-nos essencialmente em dois tópicos acerca do projeto: (i) questões filosóficas fundacionais que a proposta suscita e (ii) o esforço de dar um tratamento satisfatário nos marcos da teoria para a semântica de um conjunto de fenômenos linguísticos próprios das línguas naturais. Quanto aos problemas de ordem fundacional, preocupamo-nos, em primeiro lugar, em recuperar as objeções de Davidson a teorias que quantificam sobre significados, percorrendo de perto os problemas que ele identifica em semânticas que reificam a camada intensional dos significados das expressões de uma língua. Esse percurso se deve ao fato de entendermos - como demonstrado em especial no capítulo I - que a incompreensão da parte da crítica a teorias neo-fregeanas exposta por Davidson nos textos programáticos pode induzir interpretações equivocadas sobre a natureza do projeto. Interpretações essas que exprimem não apenas conclusões precipitadas acerca dos critérios que o projeto fornece para regular a forma geral de uma teoria do significado e do papel explicativo que Davidson espera que conceitos semânticos intensionais devem nela desempenhar. Tais leituras acabam se equivocando também quanto ao papel que uma teoria da verdade cumpre no corpo de uma teoria composicional do significado, e, por conseguinte, quanto à relação entre a teoria da verdade e o conhecimento dela. No que tange aos fenômenos linguísticos, e as alterações que eles impõem a uma teoria da verdade para que esta possa incorporá-los, investigamos uma série deles: termos sensíveis ao contexto, como pronomes pessoais e demonstrativos, que forçam a relativização do predicado de verdade às situações de uso das sentenças e uma reformulação da Convenção-T; quantificação restrita em língua natural e uma estratégia adequada para uma regimentação uniforme de tais estruturas; sentenças com verbos de ação e que descrevem relações causais entre eventos; contextos opacos criados por sentenças com verbos de atitude proposicional, e tentativas de acomodá-las a uma semântica sem introduzir entidades intensionais. Também tratamos dos desafios que coloca para a viabilidade de uma teoria semântica como a de Davidson o fato de uma língua natural possuir seu próprio predicado de verdade e os meios de descrever e se referir ás suas expressões. Alguns desses tópicos, pela sua própria natureza, invocaram questões sobre ontologia e forma lógica, lançando luz sobre compromissos ontológicos que o projeto carrega e as restrições que impõe sobre a forma lógica das sentenças.

Ao abordar este mosaico de questões motivadas pelo projeto de Davidson, procurou-se, nesta tese, principalmente demonstrar que Davidson lança as bases de um programa de pesquisa em semântica das línguas naturais cujo propósito é iluminar de forma sistemática o aspecto 
composicional do significado de amplos fragmentos e fenômenos das línguas naturais sem um apelo direto a entidades abstratas associadas às expressões de uma linguagem, como propriedades, universais, proposições, etc. Esperamos ter examinado o horizonte de expectativas de Davidson com relação ao projeto, investigando algumas de suas realizações. Mas também explorando alguns problemas, impasses e desafios que têm de enfrentar, como é de se esperar de um projeto relevante, instigador, em elaboração, sujeito a teste.

Entretanto, vários tópicos tão essenciais para a avaliação do projeto quanto os que enfrentamos ficaram de fora da tese. E não podia ser diferente, pela própria riqueza do tema investigado, os limites de tempo e espaço para o que dá para ser tratado em uma tese de doutorado e também pelas insuficiências teóricas do pesquisador. Certamente que, para uma apreciação mais completa do projeto de Davidson, alguns tópicos precisam ser investigados futuramente, como continuidade do que se iniciou e foi cumprido nesta tese. Por isso, pretendo em pesquisas de pósdoutorado enfrentar alguns deles. Para concluir esta tese, então, nas linhas que se seguem, esses tópicos serão elencados, pontuando, quando necessário, os desafios que colocam para uma semântica composicional.

Um tópico não tratado na tese é o tempo em língua natural. O significado e a verdade da maioria das sentenças em língua natural recebem, presumivelmente, a contribuição do tempo para a sua determinação. Nas línguas naturais o tempo pode ser identificado por mais de um mecanismo: advérbios temporais, inflexões verbais, etc. Há um extenso debate na literatura acerca de como tratar o tempo em um simbolismo lógico e de como acomodar em uma teoria a semântica temporal das sentenças de uma língua. Por exemplo, a conhecida lógica temporal desenvolvida por Prior, toma tempo como um operador que pode ser interpretado como um primitivo ou definido em termos de quantificação sobre instantes. Há alternativas que usam um mecanismo indexical para se referir a intervalos de tempo nos quais eventos ocorrem. O desafio para uma teoria davidsoniana consiste em conseguir acomodar os fenômenos temporais, utilizando os recursos disponíveis no simbolismo das lógicas temporais, de maneira a especificar a sua contribuição composicional para o significado das sentenças. O sucesso deste empreendimento, em virtude, por um lado, das dificuldades de se tratar tempo de forma sistemática e composicional, e, por outro lado, por ter sido um tópico por muito tempo bastante negligenciado em semântica formal, é mais uma evidência distintiva de que uma teoria como a de Davidson pode abarcar fenômenos característicos das línguas naturais comumente vistos como barreiras de impossível transposição e indicadores das limitações inerentes aos métodos formais de investigação do significado na linguagem coloquial. Em Donald Davidson's Truth-theoretic Semantics (2007) realizam avanços importantes no tratamento do tempo por uma semântica davidsoniana. Seria de grande valia para a avaliação das 
realizações de uma semântica de inspiração davidsoniana, investigar as soluções quem eles propõem, e confrontá-las com outras alternativas de explicações dos mesmos fenômenos.

Outro tópico desafiador e que apresenta sérias dificuldades para o projeto é o caso das sentenças que não possuem valores de verdade. As línguas naturais possuem uma quantidade infinita de sentenças que não são nem verdadeiras nem falsas, e que parecem não poder ser avaliadas em termos da sua verdade. Sentenças nos modos imperativo e interrogativo são casos paradigmáticos de sentenças dessas sentenças. Não faz muito sentido perguntar pela verdade ou falsidade de sentenças como „Feche a porta, agora! ${ }^{\text {ee }}$ e „Que horas são? ${ }^{\text {ee }}$. Contudo, uma semântica composicional que for capaz de acomodar essas classes de sentenças fornecendo uma explicação do seu significado na linguagem será uma teoria bastante imcompleta. Davidson em "Moods and Performances", texto de 1979, ensaia fornecer um tratamento para algumas dessas sentenças. A Nele Davidson argumenta que interrogativas, embora não sejam em si verdadeiras ou falsas, possuem respostas que são. Interrogativas cujas respostas são sim ou não, argumenta Davidson, não poderiam ser compreendidas se o falante não sabe que há duas possíveis em que uma delas é verdadeira e a outra falsa. Imperativas, por seu turno, ao expressarem comandos, seriam compreendidas por um falante somente se ele souber o que seria verdadeiro se elas forem obedecidas. A ideia subjacente é que o conceito de verdade também operaria na compreensão dessas sentenças, ainda que, claro, não via a atribuição do predicado de verdade diretamente a elas. Davidson tenta acomodar esses casos numa explicação também paratática dos modos das sentenças. Ludwig (1997) e Boisvert \& Ludwig (2006) também apresentam uma alternativa, introduzindo a noção geral de "condições de cumprimento" das sentenças. Uma apreciação das duas propostas, dos seus detalhes técnicos e realizações exige um estudo à parte, em virtude da complexidade do tópico e dos obstáculos que colocam a uma semântica de tipo davidsoniana.

Outro tema que requer uma investigação detalhada - e a respeito do qual apenas introduzimos as linhas gerais na última seção do capítulo V - para uma apreciação mais integral do projeto de Davidson é o método do intérprete radical. A introdução do interpréte radical é parte integrante do projeto. É por meio dele que Davidson procura iluminar os conceitos semânticos do campo intensional, essenciais no processo de interpretação, em especial os de tradução e sinonímia, relacionando-os a noções mais básicas, ancoradas na triangulação falante-eventos e objetos circundantes-intérprete. Com isso, intata-se demonstrar como que os conceitos centrais de uma teoria do significado podem ser empiricamente aplicados com base em evidências que, por sua vez, podem ser descritas sem pressupor esses mesmos conceitos. A questão a que se intenta responder é de como confirmar a interpretatividade de uma teoria da verdade e dos conceitos semânticos que ela emprega mediante um método que conecta verdade com o comportamento linguístico observável. 
Davidson atribui ao seu método o cumprimento de um requisito central para o sucesso do seu projeto semântico nos termos que ele concebe nos seus textos programáticos, como discutimos ao longo da tese: a confirmação que sua teoria não incorre na reificação do significado. O papel do interpréte radical no corpo da teoria do significado de Davidson, dada as questões fundacionais sobre a natureza da interpretação linguística, as relações entre evidência, fatos semânticos e teoria, por si só é um tema instigante e fundamental para o estudo da semântica de Davidson. Contudo, ele se torna um tópico ainda mais estimulante, desafiador e de difícil apreciação quando situamos o intérprete radical em relação ao método que o influenciou diretamente, o tradutor radical de Quine, e à centralidade deste para a conformação da tese da indeterminação da tradução e das teorias semânticas. A tese de Quine é que podem existir teorias ou manuais de tradução empiricamente equivalentes, no sentido de se conformarem a todas as disposições linguísticas de um falante ou grupo de falantes, e ainda assim serem logicamente incompatíveis, no sentido de fornecerem interpretações excludentes de um mesmo conjunto de sentenças. A posição de que a base evidencial sobre os significados de um conjunto de sentenças pode não ser suficiente para decidir-se entre dois ou mais manuais cumpre um papel determinante no ceticismo de Quine quanto ao estatuto científico de teorias do significado para as línguas naturais. Em contrapartida - o que pode parecer surpreendente para alguém convencido pelos argumentos de Quine - Davidson não deriva uma posição cética a partir da possibilidade da indeterminação entre teorias. Ele escreveu sobre isso. Nestes textos de interlocução com Quine, Davidson elabora sua posição sobre a indeterminação semântica e como ela emerge no contexto do intérprete radical. Este é um tema imprescindível para uma futura investigação, pois as conclusões de Quine podem colocar desafios imensos ao tipo de semântica vislumbrada por Davidson. Por essa razão, seria instigador recuperar este debate, confrontar ambas as posições e, além disso, examinar como que os resultados dele operam num momento mais tardio da sua filosofia, em que, na busca por amenizar as margens para a indeterminação entre teorias, Davidson incorpora à base evidencial do intérprete radical, além dos padrões de assentir e dissentir em relação a sentenças, possíveis fatos acerca de preferências e escolhas entre sentenças, invocando e adaptando, para tanto, elementos da teoria bayesiana da decisão.

Como pode ser notado, portanto, a pesquisa realizada nesta tese aponta para tópicos de investigações futuras que integram ou se articulam com os temas nela tratados. A apreciação desses outros tópicos - abordando as contribuições de Davidson para o tratamento deles, os desenvolvimentos posteriores encampados por outros teóricos, assim como críticas e alternativas contribuirá, indubitavelmente, para maiores clarificações dos fundamentos e aplicações do 
programa semântico de Davidson. Esta tese apenas inicia um estudo que ainda se perpetuará em novos desdobramentos. 
Apêndice: Notação das Constantes Lógicas.

$\neg$ Negação

$\rightarrow$ Implicação material

$\leftrightarrow$ Equivalência material

V Disjunção

- Conjunção

\& Conjunção

$\forall \quad$ Quantificador universal

$\exists$ Quantificador existencial

N Negação

A Disjunção

I Inclusão

П Quantificador universal 


\section{BIBLIOGRAFIA}

ARISTÓTELES (1998). Metafísica. Edição Trilíngue. Valentín García Yebra, Editorial Grecos; Madrid.

BARWISE, J \& COOPER, R. (1981). „Generalized Quantifiers and Natural Language ${ }^{e e}$. Linguistics and Philosophy. 4: 159-219.

BETTI, A. (2004). „Leśniewskie`s Early Liar, Tarski and Natural Language ${ }^{e e}$. Annals of Pure and Applied Logic, 127, 267-87.

BOISVERT, D, \& LUDWIG, K. (2006). „Semantics for Nondeclaratives ${ }^{\text {ee }}$ In Oxford Handbook for the Philosophy of Language. E. Lepore (ed.), Oxford University Press, New York.

BURGE, T. (1986). „On Davidson“s "saying that”"ee. In Truth and Interpretation: Perspectives on the Philosophy of Davidson. E. Lepore (ed.). 190-208, Blackwell, Oxford.

CAPPELAN, H. \& LEPORE, E. (1997). „Varieties of Quotation“. Mind 106 (423): 429-50.

,Semantics for Quotation “. In Philosophy and Linguistics. K. Murasugi (ed.), Boulder, Colo: Westview Press.

CARNAP, R. (1942). Introduction to Semantics. Cambridge, Massachusetts: Harvard University Press.

Meaning and Necessity: A Study in Semantics and Modal Logic. (1956 [1947]). The University of Chicago Press; Chicago.

CESAR, A. M \& DUTRA, L. H. A (2006). A Concepção semântica de Verdade: Textos Clássicos de Tarski. Editora Unesp.

CUMMINS, R. (2002). „Truth and Meaningee. In Meaning and Truth: Investigations in Philosophical Semantics. J. K. Campbell, M. O'Rourke, and D.Shier (eds.), New York: Seven Brigdes Press.

CHURCH, A. (1943), „Carnap's Introduction to Semantics“e. Philosophical Review, 52: 298-305. „The Need for Abstract Entities in Semantics Analysise (1951). Proceedings of American Academy of Arts and Letter. 80: 100-13.

Introduction to Mathematical Logic. (1956). Princeton: Princeton University Press.

DAVIDSON. D. (1990). Inquiries into Truth and Interpretation. Oxford University Press, New York.

„The Method of Extension and Intension. In A. Schilpp (ed.), The Philosophy of Rudolf Carnap. La Salle, III: open Court.

„Theories of Meaning and Learnable Languagese (1965). In Inquiries into Truth and Interpretation. Oxford University Press, New York, 3-15. 
„Truth and Meaninge (1967). In Inquiries into Truth and Interpretation. Oxford University Press, New York, 17-36.

„True to the Facts (1969). In Inquiries into Truth and Interpretation. Oxford University Press, New York, 37-54.

„Semantics for Natural Languagese (1970). In Inquiries into Truth and Interpretation. Oxford University Press, New York, 55-64.

„In Defense of Convention-Te (1973). In Inquiries into Truth and Interpretation. Oxford University Press, New York, 65-75.

„The Method of True in Metaphysics ${ }^{e e}$ (1977). In Inquiries into Truth and Interpretation. Oxford University Press, New York, 199-214.

„On Saying That (1968). In Inquiries into Truth and Interpretation. Oxford University Press, New York, 93-108.

„Moods and Performancese (1979). In Inquiries into Truth and Interpretation. Oxford University Press, New York, 109-21.

„Radical Interpretation“e (1973). In Inquiries into Truth and Interpretation. Oxford University Press, New York, 125-40.

„Reply to Fostere (1976). In Inquiries into Truth and Interpretation. Oxford University Press, New York, 171-79.

„Reality Without Reference (1977) $)^{e e}$. In Inquiries into Truth and Interpretation. Oxford University Press, New York, 215-225.

Assays on Actions and Events (2001). Oxford University Press, New York.

„The Logical Form of Action Sentencese (1967). In Assays on Actions and Events. Oxford University Press, New York, 105-21.

„Criticism, Comment and Defence ${ }^{e e}$ In Assays on Actions and Events. Oxford University Press, New York, 122-48.

„The individuation of Eventse (1969). In Assays on Actions and Events. Oxford University Press, New York, 163-80.

„Events as Particularse (1970). In Assays on Actions and Events. Oxford University Press, New York, 181-89.

„Adverbs of Action" (1985). In Assays on Actions and Events. Oxford University Press, New York, 293-304.

„Reply to Quine on Events ${ }^{\text {ee }}$.In Assays on Actions and Events. Oxford University Press, New York, 293-304.

„The Structure and Content of Truth ${ }^{e e}$. (1990). The Journal of Philosophy. 6, June. 
Truth and Predication (2005). The Belknap Press of Harvard University Press, Cambridge, Massachusetts.

ETCHEMENDY, J. (1988). „Tarski on Truth and Logical Consequence ${ }^{\mathrm{ee}}$. Journal of Simbolic Logic. 53, 51-79.

FREGE, G. (1997 [1892]). „On Sinn and Bedeutung“e. In M. The Frege Reader. Beaney (ed), Blackwell, Oxford.

FIELD, H. „Tarskiees Theory of Truth ${ }^{\mathrm{ee}}$. In The Journal of Philosophy, Vol. 69, No. 13 (Jul. 13, 1972), 347-375.

FOSTER, J. A (1976). „Meaning and Truth Theory“. In Truth and Meaning: Essays in Semantics.

G. Evans and J. MacDowell (eds.), 1-32. Clarendon Press, Oxford.

GÖDEL, K (1966) „Russell ${ }^{\text {ee }}$ Mathematical Logic ${ }^{\text {ee }}$ In Philosophy of Mathematics. H. Putnam and

P. Benacerraf (eds.), Englewood Cliffs: Prentice Hall.

HAACK, S. (1978). Philosophy of Logics. Cambridge Univesity Press, London.

HAND, M. (1991). „On Saying that Again “e Linguistics and Philosophy, 14:349-365.

KAPLAN, D. (1979). „On The Logic of Demonstratives ${ }^{e e}$, in Journal of Philosophical Logic, 8: 8198.

KIRKHAM, R, L.(1997). Theories of Truth: A critical introduction. The MIT Press, Cambridge, Massachusetts.

LARSON, R \& SEGAL, G. (1995). Knowledge of Meaning: an Introduction to Semantic Theory. The MIT Press, Cambridge, Massachusetts.

LEPORE, E (1986). „Truth in Meaningee. In Truth and Interpretation: Perspectives on the Philosophy of Donald Davidson (1986). Basil Blackwell, New York, USA, 3-26.

Meaning and Argument: An Introduction to Logic through Language. (2010 [2000]). Blackwell, Oxford.

The essential Davidson (2006). Lepore, E (ed), Oxford University Press, Oxford.

LEPORE, E \& PELLETIER. (2007). Meaning and Ontology. http://ruccs.rutgers.edu/faculty/lepore/LeporePelletierSubmit.pdf.

LEPORE. E \& LUDWIG. K (2002). What is a Logical Form. In Logical Form and Language Preyer. G \& Peter G (eds), 54-90. Oxford University Press, Oxford.

„Ontology in the Theory of Meaningee. (2006). International Journal of Philosophical Studies. $14,325-35$.

Donald Davidson: Meaning, Truth, Language, and Reality (2010 [2005]). Oxford University Press, Oxford. 
Donald Davidson's Truth Theoretic Semantics (2009 [2007]). Oxford University Press, Oxford.

LUDLOW, P (ed.) (1997). Readings in the Philosophy of Language. MIT Press. Cambridge, Massachusetts.

LUDWIG, K. (1997). „The Truth about Mood“e. In Protosociology: Cognitive Semantics I. Conceptions of Meaning. 10: 19-66.

„Was Davidson“s Project a Carnapian Explication of Meaning? Journal of the History of Analytic Philosophy, Vol. 3, number 4. 03-54.

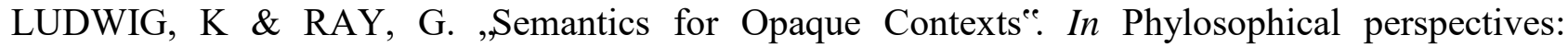
Language and Mind. J. Tomberlin (ed.), 16, 419-610, Blackwell, Oxford.

NEALE, S. (1996). „From Semantics to Ontologyee. In Donald Davidson: Truth, Meaning and Knowledge. Urszula M.Żegleń (ed.), Routledge, London.

Facing Facts. (2007). Clarendon Press, Oxford.

PETTERSON, D (2008). New essays on Tarski and Philosophy. Oxford University Press, Oxford. Alfred Tarski Philosophy of Logic and Language (2012). Palgrave Macmillan. London.

PRIOR, A, N. (1967). Past, Present, and Future. Oxford University Press, Oxford.

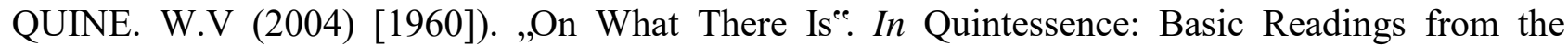
philosophy of W. V. Quine. Harvard University Press. Cambridge, Massachusetts.

(1960) Word and Object. The MIT Press, Cambridge, Massachusetts.

(2008 [1985]). „Events and Reification“. In Quine in Dialogue. F. Dagfinn \& D. B. Quine (eds.). Harvard University Press, Cambridge, Massachusetts.

RAMBERG, B (1991). Donald Davidson's philosophy of language. Wiley-Blackwell.

SCHEFFLER, I. (1954). „An Inscriptional Approach to Indirect Quotation“. Analysis Volume 14, $\mathrm{n}^{\mathrm{O}}$ 4 março, 83-90.

SEGAL, G. (1999). „How a Truth Theory Can Do Duty as a Theory of Meaningee. In Donald Davidson: Truth, Meaning and Knowledge. Urszula M.Żegleń (ed.), Routledge, London. SOAMES , S. (1992). „Truth, Meaning and Understandingee. Philosophical Studies, 65: 17-36. STICH, S. (1976). Davidson"es Semantic Program. Canadian Journal of Philosophy, 6: 201-27.

TARSKI. A (1983). Logic, Semantics, Metamathematics: papers from 1923 to 1938. Hackett Publishing Company, Indianapolis.

„The Concept of Truth in Formalized Languagesee. (1983[1933/1956]). In Logic, Semantics, Metamathematics. Indianapolis: Hackett publishing Company.

„The Semantic Conception of Truth: and the Foundations of Semantics Philosoph. (1944). Phenomenological Research, Vol. 4, No. 3, 341-376“e. 
„Truth and Proof (1969). In Scientific American Magazine, Vol. 220, Issue 6. Junho 1969, 63-77.

WITTGENSTEIN. L. (2009). Philosophical investigations. Translated by G.E.M. Anscombe, P.M.S hacker amd Joachim Schulte. Wiley-Blackwell. Oxford.

The Blue and Brown Books. (1965). Harper Torchbooks. New York. 